\title{
Fanthorp Inn State Historical Park (41GM79), Grimes County, Texas: Archeological Excavations, 1983-1989
}

Susan R. Sauer

Prewitt and Associates, Inc.

Follow this and additional works at: https://scholarworks.sfasu.edu/ita

Part of the American Material Culture Commons, Archaeological Anthropology Commons, Environmental Studies Commons, Other American Studies Commons, Other Arts and Humanities Commons, Other History of Art, Architecture, and Archaeology Commons, and the United States History Commons

Tell us how this article helped you.

This Article is brought to you for free and open access by the Center for Regional Heritage Research at SFA ScholarWorks. It has been accepted for inclusion in Index of Texas Archaeology: Open Access Gray Literature from the Lone Star State by an authorized editor of SFA ScholarWorks. For more information, please contact cdsscholarworks@sfasu.edu. 


\section{Fanthorp Inn State Historical Park (41GM79), Grimes County, Texas: Archeological Excavations, 1983-1989}

\section{Creative Commons License}

\section{(c) (i) $\Theta($}

This work is licensed under a Creative Commons Attribution-NonCommercial-No Derivative Works 4.0 International License. 


\section{INN}

FANTHORP INN

STATE HISTORICAL PARK(4IGM79), GRIMES COUNTY, TEXAS: ARCHEOLOGICAL INVESTIGATIONS,

1983-1989

by

Sandra R. Sauer

REPORT OF INVESTIGATIONS, NUIMBER II 6

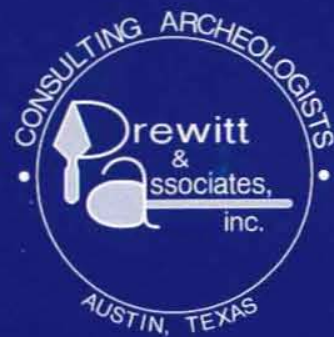

TEXAS PARKS AND WILDLIFE DEPARTMENT TEXAS ANTIQUITIES COMMITTEE

ARCHEOLOGY PERMIT NO. 303 


\title{
FANTHORP INN STATE HISTORICAL PARK (41GM79), GRIMES COUNTY, TEXAS: ARCHEOLOGICAL \\ EXCAVATIONS, 1983-1989
}

by

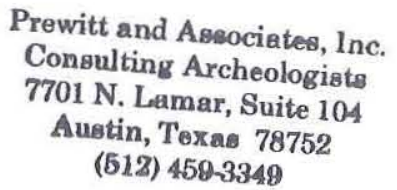

Sandra R. Sauer

with a Contribution by

Sue Moss

Principal Investigators: Art Black and Ross C. Fields

REPORTS OF INVESTIGATIONS, NUMBER 116

\author{
Prewitt and Associates, Inc \\ Consulting Archeologists \\ Austin, Texas
}

January 1998

TEXAS ANTIQUITIES COMMITTEE ARCHEOLOGY PERMIT NO. 303 
, 


\section{TABLE OF CONTENTS}

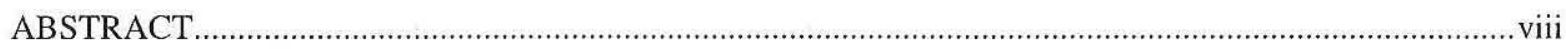

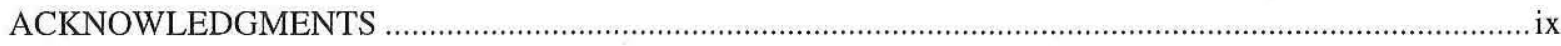

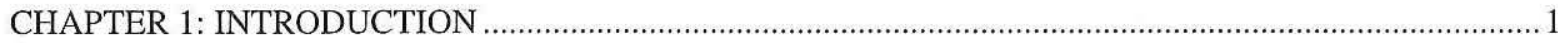

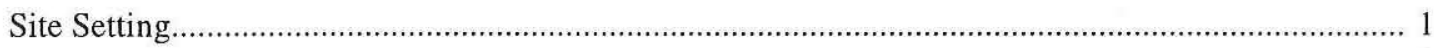

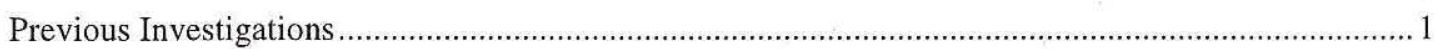

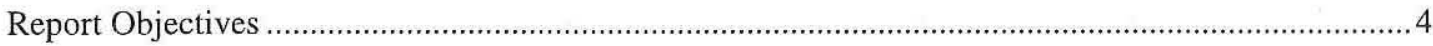

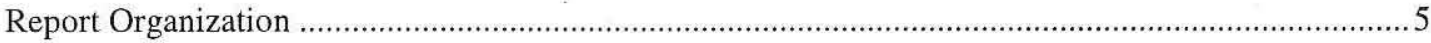

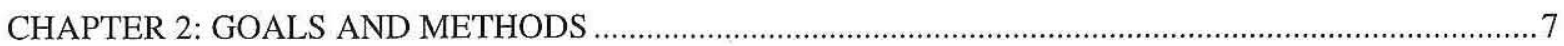

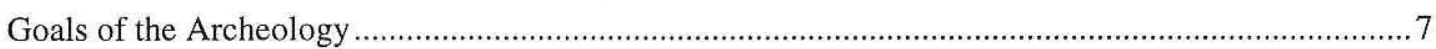

Archeological Field Methods ………..........................................................................................

Historical Research Methods ..........................................................................................................

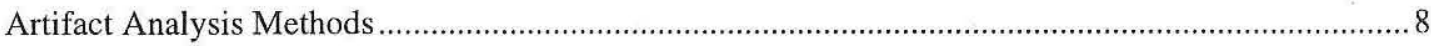

CHAPTER 3: HISTORY OF FANTHORP INN (by Sue Moss) .................................................................. 11

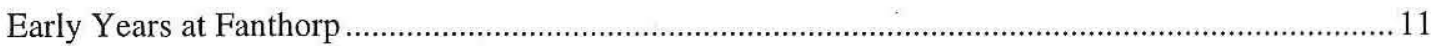

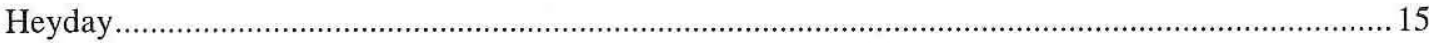

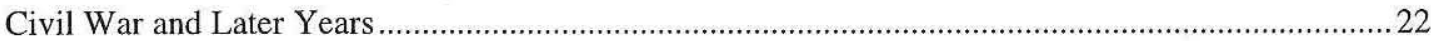

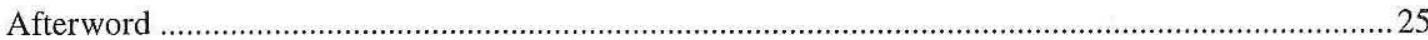

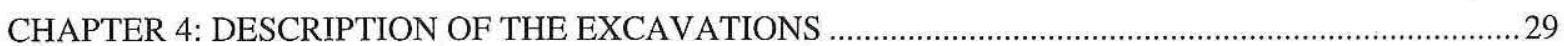

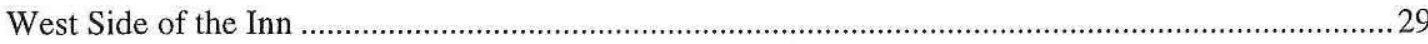

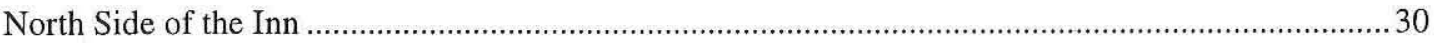

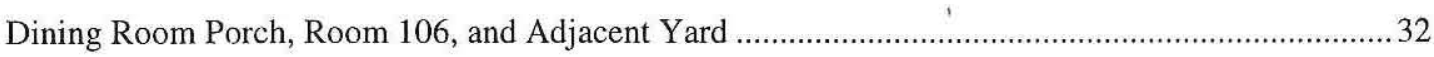

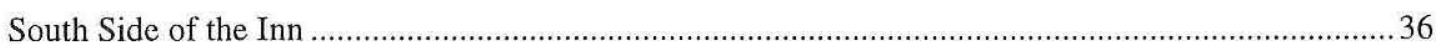

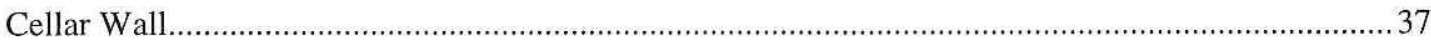

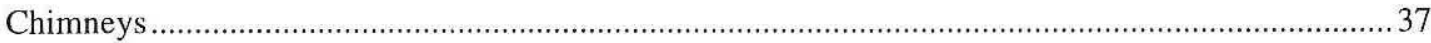

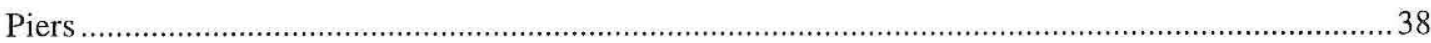

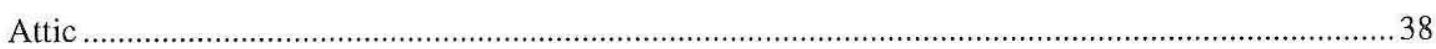

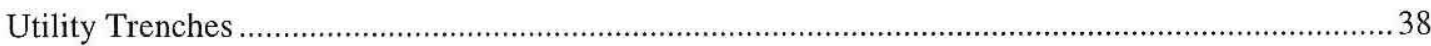

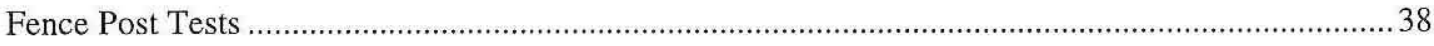

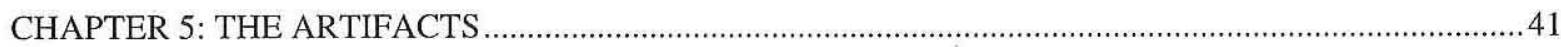

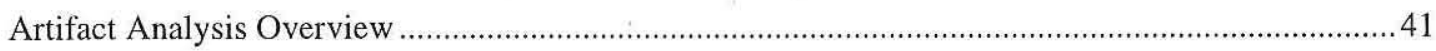

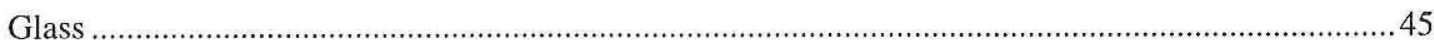

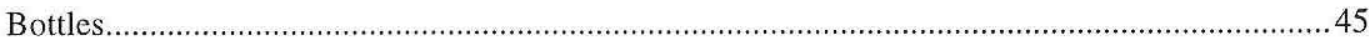

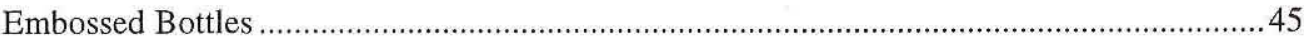

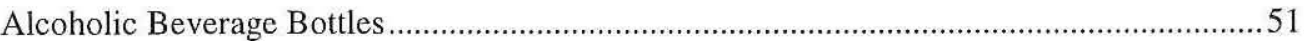

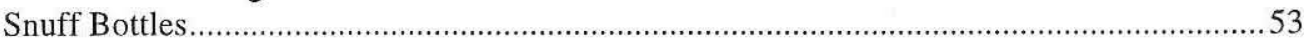

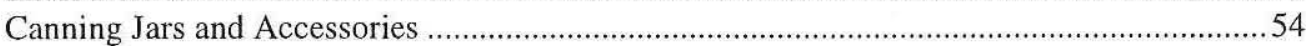




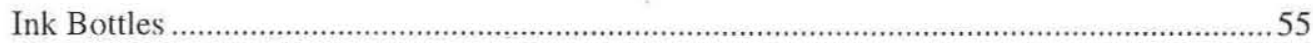

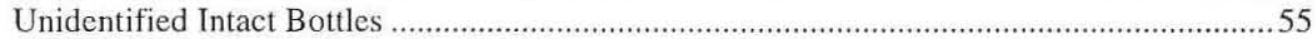

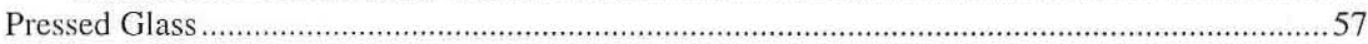

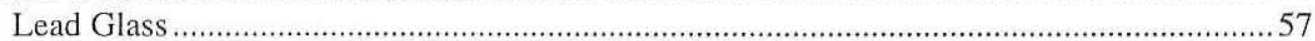

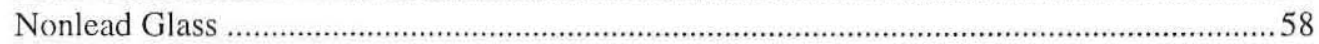

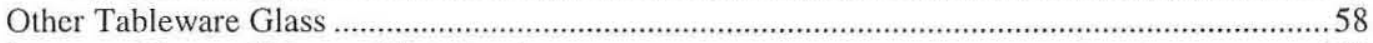

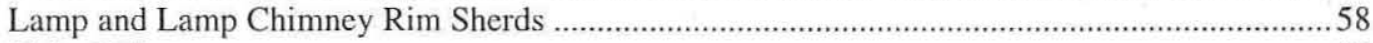

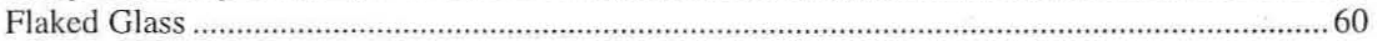

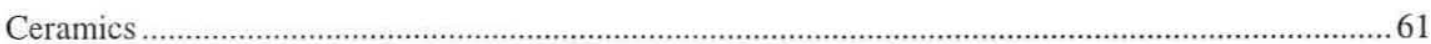

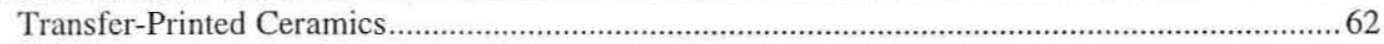

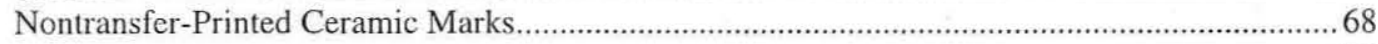

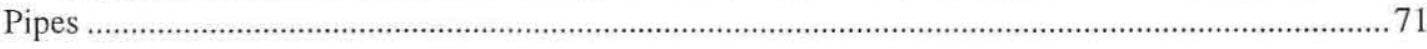

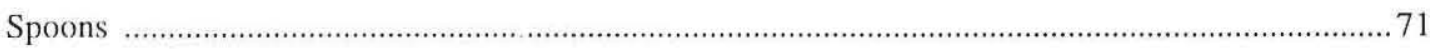

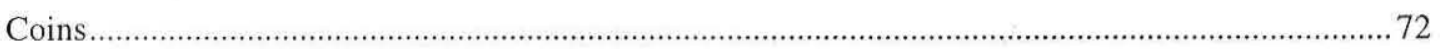

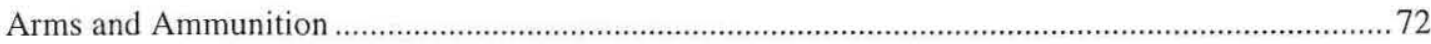

Toys

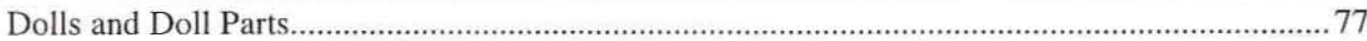

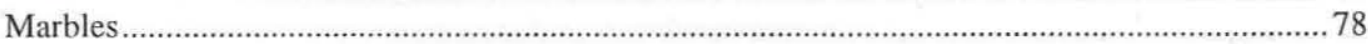

CHAPTER 6: AFRICAN AMERICAN SPIRITUALITY AT FANTHORP INN ........................................79

African and African American Religious Practices: A Brief Background .................................... 79

Archeological Evidence of African-Influenced Practices...................................................... 80

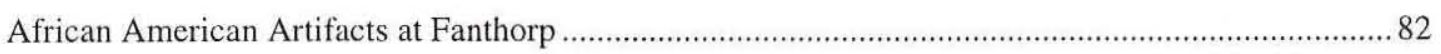

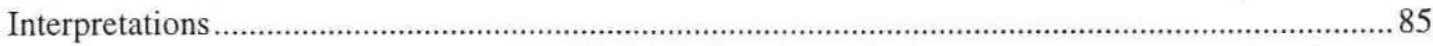

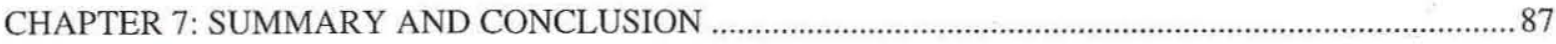

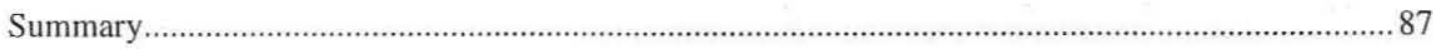

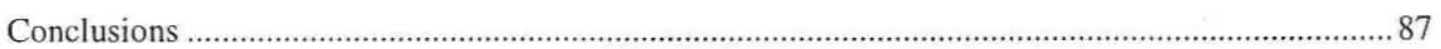

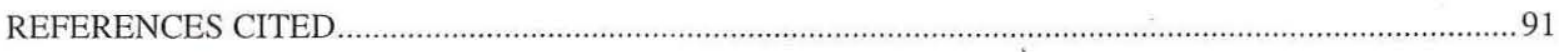




\section{LIST OF FIGURES}

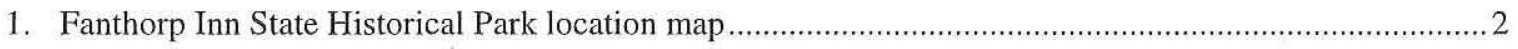

2. Plan map of the Fanthorp State Historical Park site .................................................................................... 3

3. Photographs of Rachel Kennard Fanthorp and Henry Fanthorp.......................................................12

4. Map of stage lines running through Anderson...................................................................................... 18

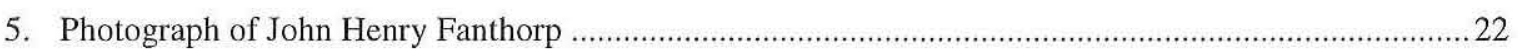

6. Photographs of Mary Ann Fanthorp Stone and Major William M. Stone ................................................24

7. Photographs of Eleanor Stone McDonald and Judge James G. McDonald, Jr.......................................26

8. Plan of the first floor of the inn as reconstructed by TPWD ................................................................... 30

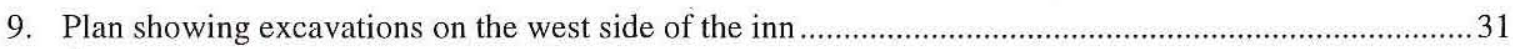

10. Plan showing excavations on the north side of the inn .......................................................................... 32

11. Plan showing excavations beneath the dining room porch (Room 111) and

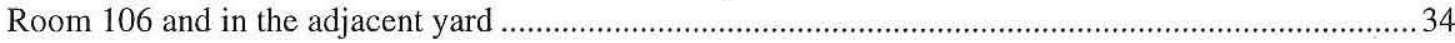

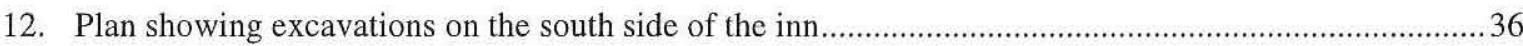

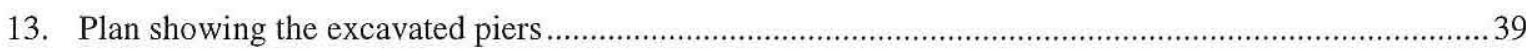

14. Plan showing utility trenches dug in 1986 and 1987 and fence post tests dug in 1989 .........................40

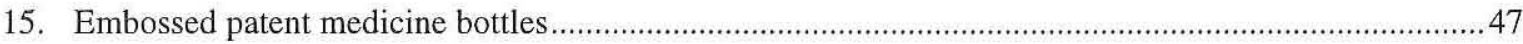

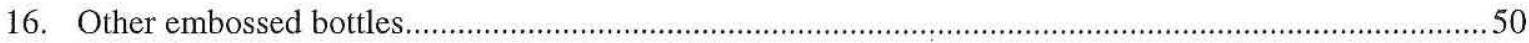

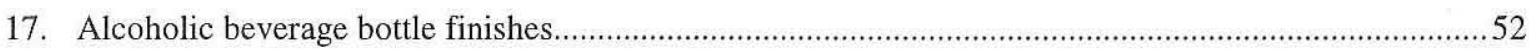

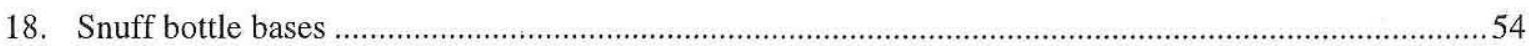

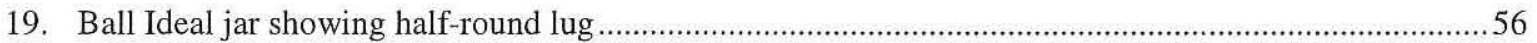

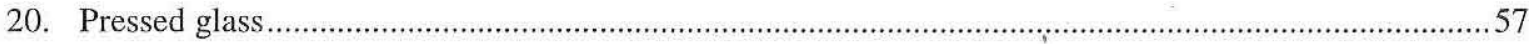

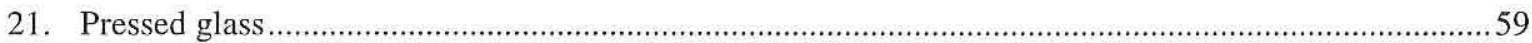

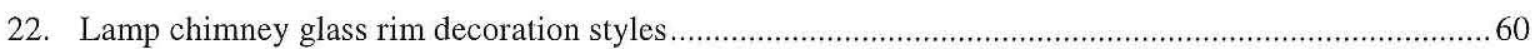

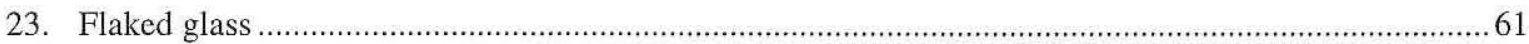

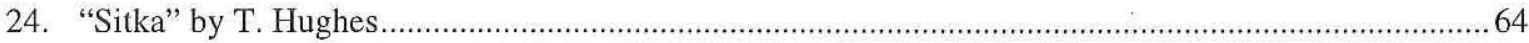

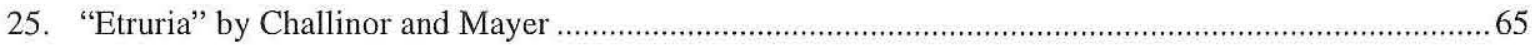

26. "Agricultural Vase" by Ridgway, Morley, Wear \& Co.............................................................................66 66

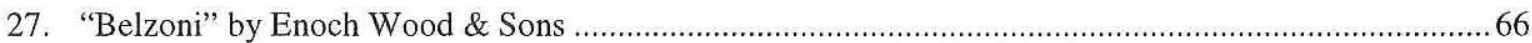

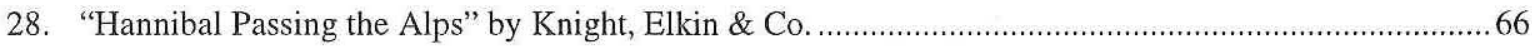

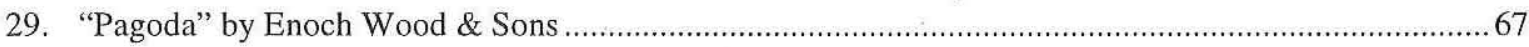

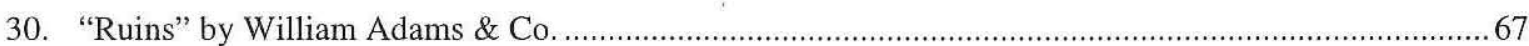

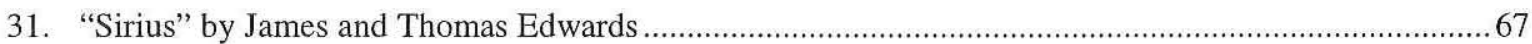

32. Oak leaf pattern by David Johnston of Bordeaux, France ............................................................... 68

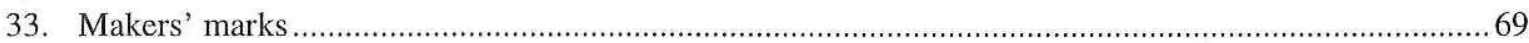

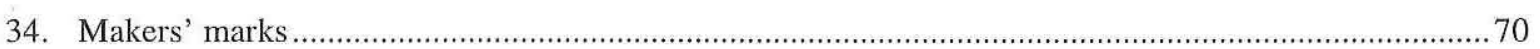




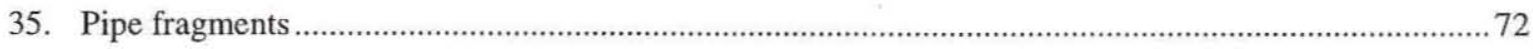

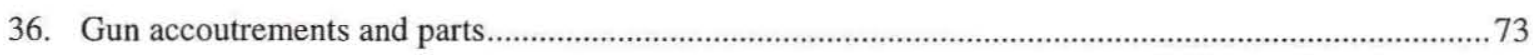

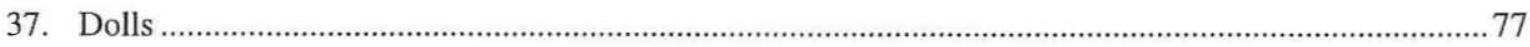

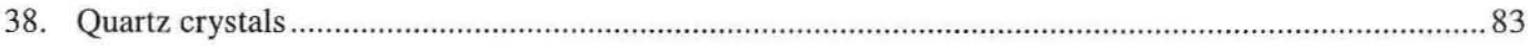

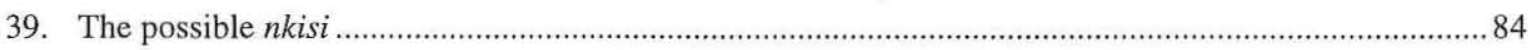




\section{LIST OF TABLES}

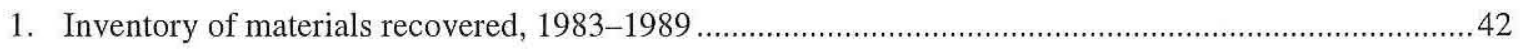

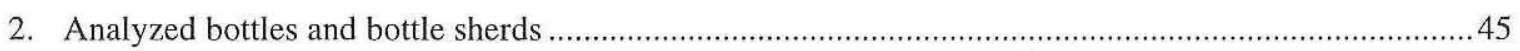

3. Date ranges for patent medicine bottles from Fanthorp Inn .................................................................... 46

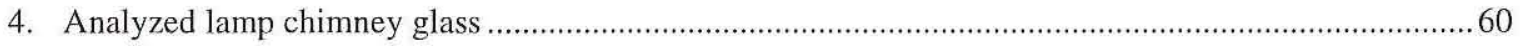

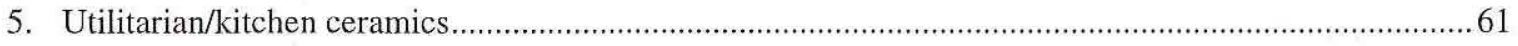

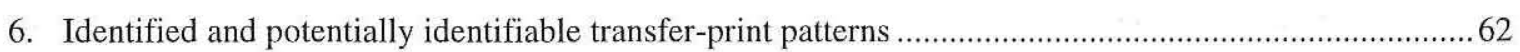

7. Potentially identifiable marks on nontransfer-printed ceramics ............................................................ 71

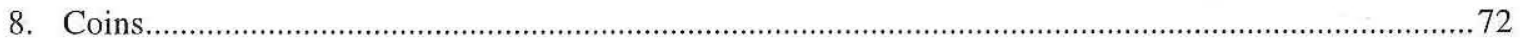

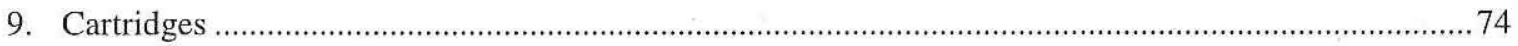

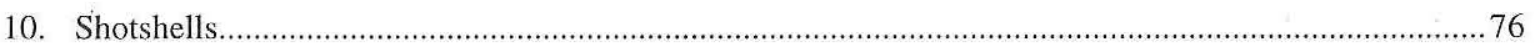




\begin{abstract}
This report summarizes archeological investigations conducted by the Texas Parks and Wildlife Department at Fanthorp Inn State Historical Park from 1983 to 1989. This work was necessary to accompany architectural restoration of the inn as it appeared during the period between 1850 and 1867 . Since restoration was completed, Fanthorp Inn State Historical Park in Anderson, Grimes County, has been run as an interpretive site representing a transportation and communication center of the mid-nineteenth century.

The archeological excavations were intended to evaluate the areas impacted by the architectural restoration and to determine the appearance of the grounds during the mid-nineteenth century. Attempts were made to locate and identify several outbuildings shown on an 1850 map of the inn, but only the kitchen was located in this manner. Also, areas of ground disturbance such as the locations of the septic system and utility trenches were investigated archeologically. As currently configured, the grounds are made up of the L-shaped inn building, a barn that houses restrooms and a display, a parking lot, fences and paths, the kitchen as represented by a stabilized foundation, and one cistern that has been rebuilt to its original appearance.
\end{abstract}

This report, by Prewitt and Associates, Inc., summarizes the excavations from 1983 through 1989 and provides analyses of diagnostic artifacts (i.e., bottles and jars, pressed glass, other tableware glass, lamp chimney rim sherds, flaked glass, transfer-printed ceramics, marked ceramics, smoking pipes, marked spoons, coins, arms and ammunition, dolls, marbles, and artifacts believed to be associated with African American religious practices). In general, the assemblage reflects a typical nineteenth- and twentiethcentury site in southeastern Texas. 


\section{ACKNOWLEDGMENTS}

A great deal of assistance in the preparation of this report was provided by personnel from the Texas Parks and Wildlife Department. Art Black was the Principal Investigator for the excavations and assisted with interpretation of the data concerning the work conducted at the site. Former Cultural Resources Program Director Cynthia Brandimarte provided coordination for the project. Aina Dodge, director of the Archeology Laboratory, organized the artifacts prior to delivering them to Prewitt and Associates and provided additional information as requested.

At Prewitt and Associates, Ross Fields served as Principal Investigator for this analysis. Linda Foster and Ross Fields edited the text and tables. Audra Pineda pulled the diagnostic artifacts for analysis under the supervision of Karen Gardner. Sandra Sauer took the artifact photographs, and Ellen Atha did the hand-drawn artifact illustrations. Brian Wootan produced the photographic and illustrative figures. Linda Foster produced the report. 



\section{INTRODUCTION}

Fanthorp Inn State Historical Park is located in Anderson, Grimes County, Texas (Figure 1). The inn is run as an interpretive site representing a transportation and communication center of the midnineteenth century. The log house that would become Fanthorp Inn was built in 1834 by Henry Fanthorp on a quarter league of land purchased from Francis Holland, one of Austin's Three Hundred. Originally built as a residence, the dogtrot house became the location of a stagecoach stop and, after some additions and renovations, was developed into an inn. The inn operated between the late 1830s and 1867, after which various descendants of the Fanthorp family again used the building as a residence until the 1970s. In 1974 the property was entered into the National Register of Historic Places as part of the Anderson, Texas Historic District. The site was selected to be part of the state historical park system and as such was purchased in 1977 by the Texas Parks and Wildlife Department (TPWD).

Since the TPWD objective for this site is to represent the inn as it was in the period between 1850 and 1867, renovations of the inn building were necessary. In conjunction with the architectural research needed for the renovation efforts, historical and archeological research were conducted to determine what the house and grounds looked like during the mid-nineteenth century. Several outbuildings are shown on an 1850 map of the inn and surrounding area, but none of these structures survived to the 1970s. Archeology was used in an attempt to locate and identify these buildings, but with the notable exception of the kitchen building, these efforts were not successful. Archeological findings proved vital, however, in providing data to redecorate and furnish the inn building. In particular, duplicates of the ceramics and pressed glass found at the site have been used to re-create the dining room setting in the current display.

In addition to data collection for restoration purposes, archeology was conducted in those areas where ground disturbance would occur. These in- cluded the ground under selected room floors that were to be replaced, yard areas where the septic system and utility trenches were to be laid, and other areas in and around the house and kitchen. Archeological excavations were conducted by TPWD in 1978, 1982, 1983, 1984, 1985, 1986, 1987, and 1989. Reports for 1978 and 1982 were written by TPWD personnel (Burnett 1981; Ing and Hart 1987). This report summarizes the archeological excavations conducted during the 1983 through 1989 seasons.

The Fanthorp Inn grounds are currently made up of the L-shaped inn building, a barn structure that houses restrooms and a display, and a parking lot. Fences and paths are also present. The kitchen building is represented by a stabilized foundation, and one of the cisterns has been rebuilt to its original appearance (Figure 2).

\section{SITE SETTING}

Fanthorp Inn is located in Grimes County and is surrounded by the rolling blackland prairie, which is used predominantly for agriculture. The sediments consist of shallow, well-drained calcareous soils formed in beds of calcareous sandstone that are of the Renish complex. Vegetation in the region includes a variety of East Texas species. At the site, however, the vegetation is primarily the result of landscape introductions by various owners (Ing and Hart 1987:1).

\section{PREVIOUS INVESTIGATIONS}

The August 1978 season consisted of test excavations in four areas. The first was a grassy area northwest of the inn that had been selected as the site for the parking lot. In total, $117 \mathrm{ft}$ of backhoe trenches were excavated along the east and south edges of the parking area, and thirteen $3-\mathrm{x}-3-\mathrm{ft}$ test pits were hand dug throughout the area. No recognizable features were found, and the artifacts recovered were deemed insignificant. The second area 


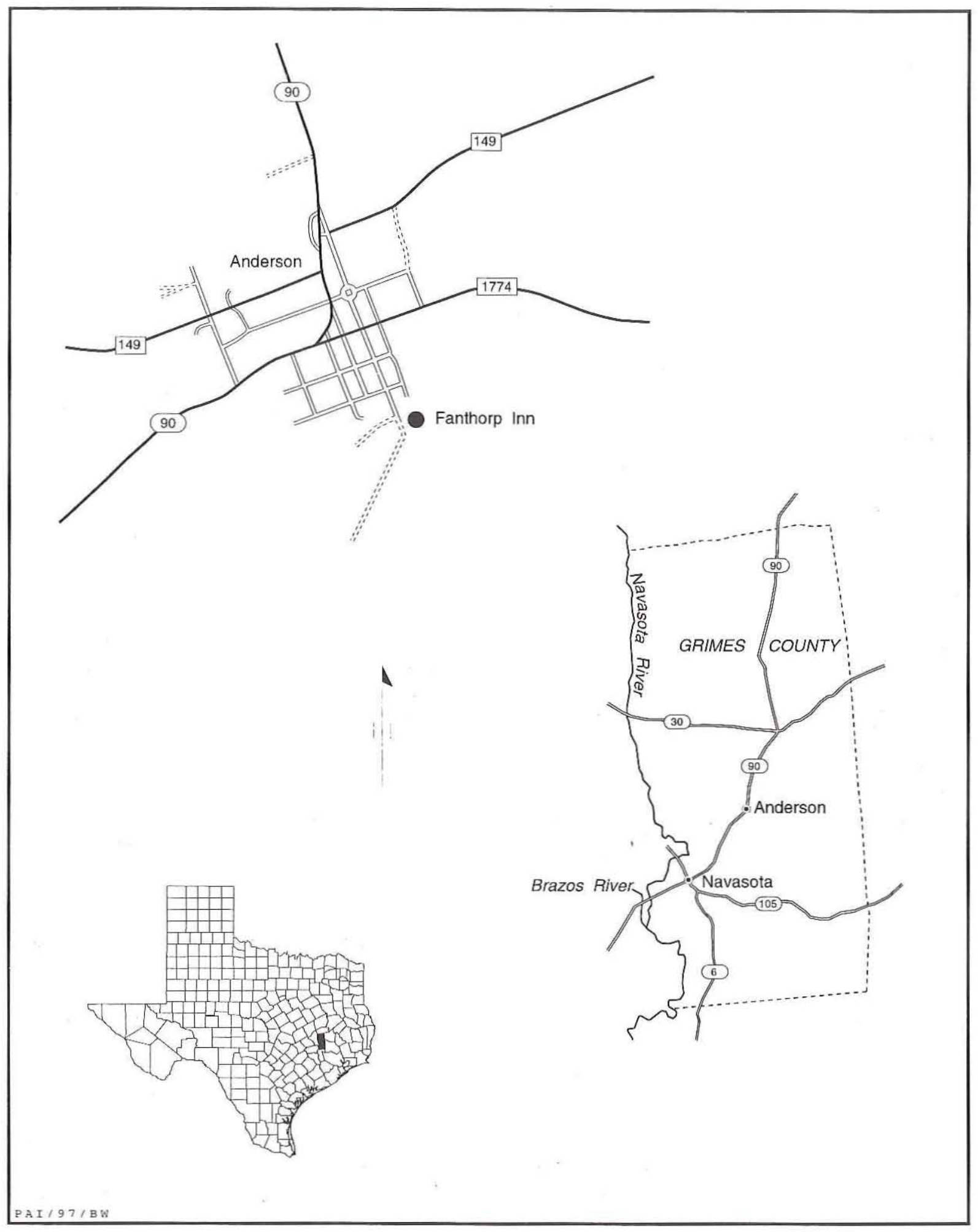

Figure 1. Fanthorp Inn State Historical Park location map. 


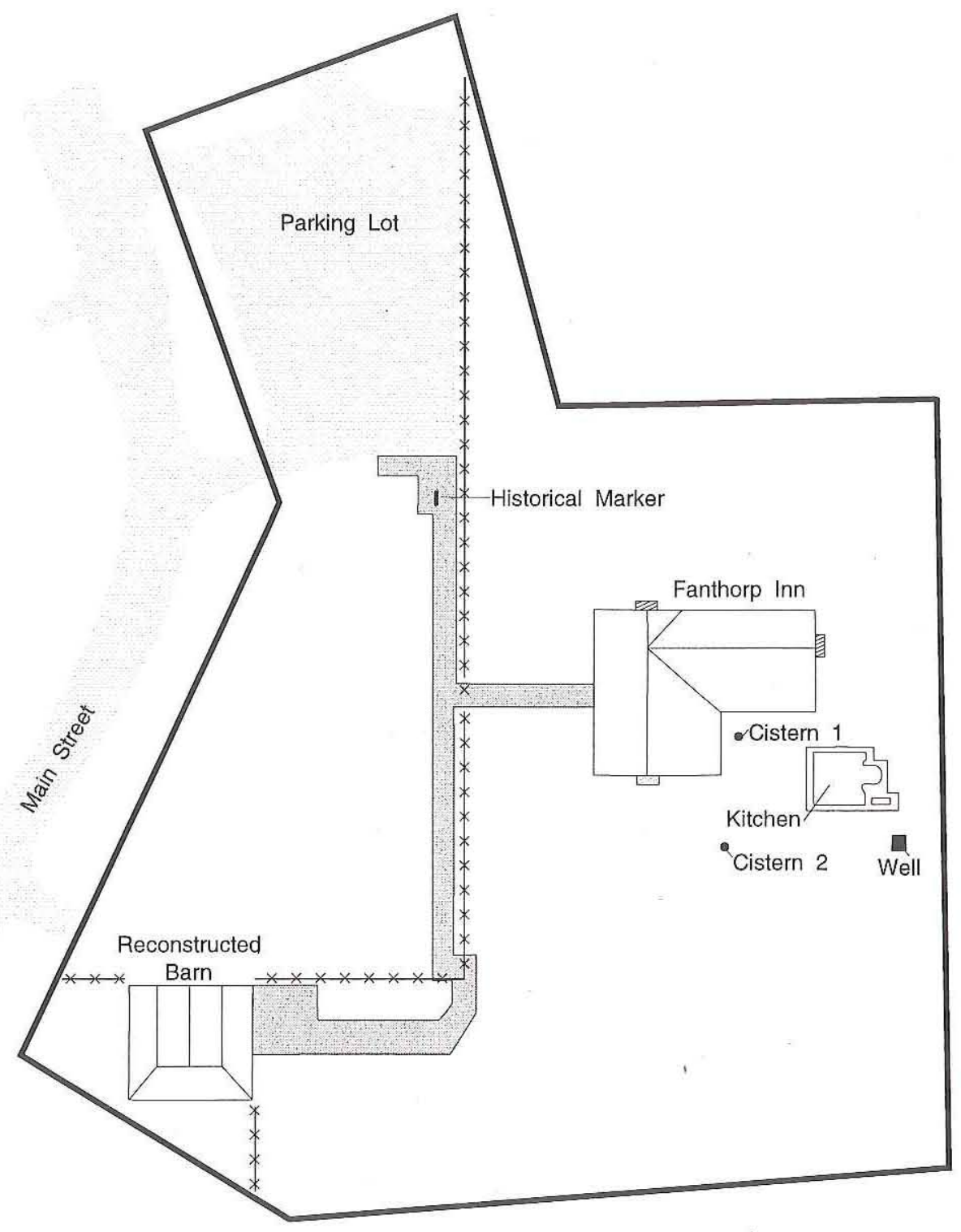

LEGEND

$$
\begin{gathered}
\square \text { Gravel Walkway } \\
\square \text { Park Boundary } \\
* * * \text { Fence } \\
\text { Chimney } \\
\text { PAI/97/BW }
\end{gathered}
$$

Figure 2. Plan map of the Fanthorp Inn State Historical Park site. 
investigated in 1978 was on the north side of the inn where, according to historical and family accounts, a 14- to 16-room addition once stood. This was investigated through the excavation of a 2 -ft-wide trench, which exposed a linear arrangement of flat rocks and yielded building-related artifacts. The third area investigated was east of the inn, where two $2-\mathrm{x}-10-\mathrm{ft}$ trenches were excavated to test an artifact scatter. Large numbers of nineteenth-century artifacts mixed with later materials in the upper levels were recovered. A circular depression south of the inn also was investigated through the excavation of an L-shaped unit measuring $2 \times 5 \mathrm{ft}$, revealing the remains of an abandoned cistern. From the photographic and archeological evidence, it is clear that the cistern was abandoned early in the twentieth century.

The 1982 field season investigated three areas around the inn building. The first was to the southwest where several sources, including a map, a photograph, and oral accounts, indicated that a barn or stables had been located. Three 3-x-3-ft units and 10 posthole tests in this area revealed very low concentrations of artifacts. No structural remains or other features were found in these excavations.

Exploration for the addition north of the inn in 1982 consisted of a series of 2-x-2-ft units, a $2-x-3-f t$ unit, a 3-x-5-ft unit, and a $2-\mathrm{x}-15-\mathrm{ft}$ trench. The only feature found was a group of four large sandstone blocks northwest of the house. These stones covered an area of around $16 \mathrm{ft}^{2}$ and were found with rubble and mortar in between. From this evidence, it appears that if an addition stood north of the house, it may actually have been a separate detached building. Further excavation was deemed necessary to determine the exact nature of these remains, although a 20 - $\mathrm{x}-30$-ft building oriented along an east-west axis with a fireplace in the west wall was suggested. Ceramics found in and around the area in 1978 suggest a mid-nineteenth-century building that was probably gone by 1870 (Ing and Hart 1987:17-18).

The most intensively investigated area during 1982 was the kitchen structure east of the inn building. Documentary evidence suggested that a kitchen was built by Henry Fanthorp in 1848, and oral history supported this contention. Several large test units were placed east of the house in an attempt to find the remains of the kitchen building. One 3-x-6-ft unit was placed northeast of the inn. When no remains were found in that location, two more test units were excavated south of the first one. These were $3 \times 6 \mathrm{ft}$ and $3 \times 9 \mathrm{ft}$ in size; one was aligned with the north wall of the inn, and the other was against the east property line. No structural elements were found in either of these units.
A low mound approximately $25 \mathrm{ft}$ southeast of the inn was the next target of archeological investigations. A 3-x-6-ft unit was placed on the eastern edge of this mound, and it was here that the remains of the kitchen were finally found. The entire kitchen and several adjacent feet were excavated. The building remains include a stone foundation about $20 \mathrm{ft}$ square with walls $1.8 \mathrm{ft}$ wide. A hearth and chimney foundation $9 \times 2 \mathrm{ft}$ in size were centered in the east wall of the kitchen structure. The chimney had been set into a trench dug down to bedrock to support the mass of the chimney (Ing and Hart 1987:24). The firebox was estimated at $3.5 \times 5.5 \mathrm{ft}$. The floor was made of flagstones, and a 5-x-7-ft cubicle had been added to the southeast corner of the kitchen. Feature 1 was a pit dug through the flagstone floor. The pit contained ash and pig bones and is assumed to have been dug after the kitchen was abandoned. Five postholes were also found in the area of the kitchen. A dumping area containing both nineteenth- and twentieth-century materials was identified east and south of the kitchen.

Two other areas east of the house were investigated to search for other outbuildings noted on an early map. One area southeast of the house and west of the well revealed several scattered flat slabs of sandstone. The other area was located about $30 \mathrm{ft}$ south of the well where six connected, 2-ft-wide trenches were excavated. This area was selected due to an increase in nineteenth-century ceramics found on the surface. A roughly oval rubble deposit approximately $19 \times 9 \mathrm{ft}$ was found through these excavations. The bones and nineteenth-century ceramics found on the surface continued through the rubble to sterile soil, but structural integrity could not be determined. It was suggested that additional excavations would be necessary to determine the nature of these deposits.

\section{REPORT OBJECTIVES}

This report fulfills three primary objectives by providing a description of the work performed in the 1983-1989 field seasons, an inventory of all artifacts excavated, and detailed analyses of selected artifacts. The report also serves to elucidate the history of the site and its place in Grimes County history so as to provide a context through which to study the archeological findings. Specific groups of artifacts help to illuminate social aspects of life at Fanthorp during certain periods, including African American spirituality primarily during the nineteenth century and a turbulent period in Grimes County at the beginning of this century. Detailed distributional studies were not attempted due to the high traffic nature of most areas 
excavated. It was felt that disturbance had been extensive in most areas, thus rendering the results of any distributional analysis questionable. This assumption was based on the 1982 season analysis, during which it was found that in almost every case the only distributional studies that were worthwhile were in the Kitchen feature.

\section{REPORT ORGANIZATION}

This report consists of seven chapters. Chapter 1 has provided the basic background to the present research, the location and setting for Fanthorp Inn, a brief description of the two previous excavation seasons, and the objectives of the report. Chapter 2 outlines the goals of the archeology and details the methods used in the excavations, the historical research, and the laboratory analysis. Chapter 3 provides the historical background for the Fanthorp site as written by Sue Moss for TPWD in 1983.
Chapter 4 provides descriptions of the areas excavated in 1983-1989. The locations described include four large, general areas where most of the excavations occurred, as well as six smaller, morespecific areas and features in and around the house that were not easily incorporated into the descriptions of the four larger areas. Chapter 5 is the artifact analysis chapter. A selected group of diagnostic artifacts is described in this chapter, including bottles, diagnostic pressed glass and other tableware glass, decorated lamp chimney rim sherds, flaked glass, ceramics with identifiable transfer-print designs or makers' marks, smoking pipes, marked spoons, coins, ammunition and gun parts, dolls, and marbles. Artifacts believed to be associated with the African American residents at Fanthorp are discussed in Chapter 6. Chapter 7 provides conclusions reached as a result of the artifact analysis and historical research as well as a summary of the report. 



\section{GOALS AND METHODS}

\section{GOALS OF THE ARCHEOLOGY}

The Historic Sites and Structures Act, passed in 1967, was instituted to protect and preserve the heritage of the state for the benefit of the people of Texas. With the passage of this act, the Texas Legislature mandated the Texas Parks and Wildlife Department to acquire, develop, and interpret important historic sites; Fanthorp Inn was chosen as one of these sites. "The primary significance of the Fanthorp inn site lies in its representation of a mid nineteenth-century Texas transportation and communication center" (TPWD 1983:I:5). In order to open to the public as a historic site, the Fanthorp Inn building had to be restored to its midnineteenth-century state. In addition, modern utilities and a septic system had to be installed, and a barn building that would house rest rooms and a display needed to be built.

The main goal of the TPWD's Preservation Plan and Program for Fanthorp Inn was to preserve and restore the site "to the period between 1850 and 1867" (TPWD 1983:I:5). Architectural research was the primary source of information for this restoration, but historical and archeological research were also utilized to this end. The main goals of the archeological research were to search for other buildings on the inn grounds and to investigate those areas that would be disturbed by the restoration.

Areas in the inn yard, the kitchen, the cisterns, and the house were excavated. With the exception of one drainage ditch, no excavations extended to areas outside the boundaries of the property purchased by the state. Therefore, areas specifically related to the operation of the farm, the stage line; and the post office were not excavated. Such areas as the slaves' quarters, barns, fields, etc., are not studied in this research because they are also outside the property boundaries.

\section{ARCHEOLOGICAL FIELD METHODS}

Standard archeological field procedures were used to control the excavations. A horizontal grid set up during the 1978 field season was adhered to during the 1983 and 1984 field seasons. In those instances where the grid was not utilized, excavation areas were recorded in relation to the house structure. Excavation units were identified by coordinates (e.g., S245-248, E205-208), by number (e.g., Unit 111-5), or by name (e.g., F.G.W. \#5). A granite commemorative monument, the northwest corner of which stood at S175/E112, was used as a vertical control. The elevation at the top west of this monument is 346.56 $\mathrm{ft}$ above median sea level. When necessary, a unit elevation datum was utilized.

Natural levels were used to record data for most units, although in șome instances artificial levels were used. All soil removed during the excavations was screened through $1 / 4$-inch mesh. One-eighth-inch mesh and window mesh were used on an irregular basis to fine screen for smaller artifacts. To save time in the field, the smaller fraction from the window mesh and 1/8-inch mesh was often bagged for sorting in the lab. Artifact bags were labeled with the excavator's name, unit location, level, date, and any other pertinent information. Each bag was assigned a separate lot number; the catalog number on each artifact consists of the site number and the lot number with a hyphen between.

Excavation notes were kept by each archeologist. Floor plans and profiles of units were drawn when necessary, and both black-and-white photographs and color slides were taken to visually record the site. All records are on file at TPWD.

\section{HISTORICAL RESEARCH METHODS}

The history section of this report was researched and written by Sue Moss, a researcher for 
TPWD, and was first presented in the 1983 preservation plan and program for the site (TPWD 1983, Vol. II). In the 1980s, TPWD historian Cynthia Brandimarte conducted oral interviews with several family members and other people who had been familiar with the house. No further historical research was conducted by Prewitt and Associates.

\section{ARTIFACT ANALYSIS METHODS}

The large size of the collection from the Fanthorp excavations (more than 119,000 items) dictated a less than conventional treatment of the artifacts. Because it was impractical to make a detailed analysis of every artifact from the site, the inventory produced by TPWD laboratory personnel was used to summarize all of the artifacts recovered. Then, artifact classes that are the most diagnostic along with classes that have unique comparative potential were chosen for more-detailed analysis.

The summary of all artifacts collected was done through a coding system developed by TPWD and based on a classification system created by Roderick Sprague and his students (Sprague 1981). All of the artifacts collected during the 1983-1989 field seasons had been cataloged by personnel at the TPWD archeology lab. That is, each artifact had been recorded in a list for each lot, and each artifact had been assigned to a functional class. Therefore, when PAI received the artifacts for this analysis a list of all artifacts already existed, although the list had not been fully coded into the TPWD system. The tasks that remained to produce the artifact summary consisted of (1) completing the artifact coding based on the identifications made by TPWD laboratory staff (no efforts were made to check the accuracy of the identifications, although obvious errors were corrected when noted), and (2) entering the data into a spreadsheet for manipulation.

The artifacts selected for more-detailed analysis were those with the greatest diagnostic and comparative potential. The first group of artifacts to be considered for analysis was ceramics. TPWD staff had separated most of the ceramics out of the general collections and sorted them into general decoration categories, including transfer prints, makers' marks, hand painted, sponge and spatter, mocha, decal, etc. In the analysis reported here, PAI lab staff went through the artifact bags, pulled any remaining diagnostic ceramics, and counted all of the ceramics by decoration type. The transferprinted earthenware ceramics were chosen for moredetailed analysis because they have great diagnostic potential. That is, transfer-printed wares from the nineteenth century have been well studied, and the patterns and, when available, makers' marks can provide detailed information about where and when the pieces were made, as well as who made them and sometimes who imported them. This artifact class can also allow inferences about socioeconomic standing. Makers' marks were chosen for analysis for many of the same reasons as the transfer prints, i.e., they can indicate maker, geographical source, decoration name, time range, and sometimes importer.

Another large class chosen for detailed study is bottle glass, since bottles have been extensively recorded in the literature and can indicate trade sources, food preferences, and socioeconomics. The diagnostic bottle glass described includes intact bottles, finishes, bases, and embossed body fragments. The types of bottles found include patent medicine, graduated, cosmetic, alcohol, snuff, ink, and unidentified complete bottles and canning jars.

Pressed or pattern glass contains designs that often can be identified to maker and time period. This is also an artifact class that has been extensively researched by collectors, and a body of literature has been produced on the different patterns and makers. Those pieces chosen for description here are the ones with potentially identifiable patterns (not pieces that are simply fluted or paneled) and those that are made of lead glass. Other glass tablewares are touched on briefly to give a better idea of how many types of tablewares were used at the inn. While separating the pressed glass from the other tablewares, a large number of tumblers, wine glasses, and other glass tablewares were identified, and a count of these is provided.

Coins were chosen for discussion because of their time-diagnostic qualities. Also described are gun-related artifacts because they can provide information on maker, production dates, and source, and they provide clues to specific activities such as hunting, target shooting, and self defense. Dolls and marbles were selected as representatives of the toy class - the class that best gives insight into the lives of the children at the site-as they are well documented in the literature. Two spoons with identifiable marks are described because they are datable and identifiable to makers.

Another class chosen for analysis is quartz crystals. These crystals may have been brought to the site by the African American slaves who were owned by Henry Fanthorp prior to the Civil War or the freedmen who chose to stay on at the inn after emancipation, and hence they may relate to spiritual beliefs and practices. Also found at the inn and 
perhaps relevant to this topic is a bundle of paper packets wrapped in a cloth that are believed to be a nkisi, or African spirit bundle.

Lamp and lamp chimney rim fragments are discussed because of the quantity and variety of styles found at the site. Few reports include detailed analysis of lamp chimney rim sherds, and this site provides examples of both rare and common types. Flaked glass is discussed here because it presents an aspect of material culture that is not well recorded and provides comparative examples for other researchers. Pipe fragments are touched on briefly because they are decorated in a variety of ways and also can provide a comparative collection for other researchers.

The artifact classes not included in the detailed analysis were excluded because it was expected that they would yield relatively little important information. The largest group of identified artifacts excluded from the analysis is the architectural materials. The inn building was still standing when the archeology was conducted, and the architecture is well understood. In fact, the inn has been restored, and it was felt that studying the architectural materials recovered archeologically would provide little new information. Any artifacts that would provide no information beyond material and number were also excluded from analysis. This includes the majority of the unknown group including unidentifiable fragments of ceramic, metal, glass, plastic, leather, rubber, fabric, etc. Also excluded for this reason are fence staples, horseshoes, horseshoe nails, fishing weights, most clothing artifacts (grommets, zippers, shoelace tips, hooks and eyes, studs, buckles, snaps, cuff studs, other hardware, etc.), safety pins, straight pins, clothespins, comb teeth, keys, and matchsticks.

Faunal remains are not analyzed because a large sample of animal bones (1,588 identifiable and 11,647 unidentifiable specimens) recovered during the 1982 excavations was studied and reported by Assad (1987). Although some additional information could be gained about foodways from the 1983-1989 sample, the time it would take was not justifiable considering that previous data were already available.

A collection of 199 buttons also is presented in the earlier report (Pool 1987). Because of this and because buttons have little diagnostic potential (i.e., they are hard to date and source), those collected in 1983-1989 are not described here. Beads also have low diagnostic potential and were not analyzed.

Personal items such as brushes, toothbrushes, combs, dentures, makeup containers, eyeglasses, etc., generally provide little information about source and specific time period. The reason for this is that, unless marked, all companies produced similar products, and they generally changed slowly over time. Broad time periods could be determined, but this is not necessary at a site where the chronology is well known.

Only certain toys are diagnostic. Other than the dolls and marbles, toys such as jacks, harmonica fragments, and plastic furniture hold little interpretive potential unless marked, and because of this and their small numbers, they are not included in the detailed analysis.

Other than the transfer-printed ceramics, ceramics with makers' marks, certain pressed glass artifacts, bottles, glass tablewares, and marked spoons, kitchen-related artifacts such as other ceramics, most utensils, cookware, tin cans, stove parts, etc., are not included in the discussion because they have relatively little diagnostic potential. Although tin cans can be informative, the ones found at Fanthorp are highly fragmented and corroded. Likewise, without marks or identifiable patterns, ceramics have little interpretive potential. Utensils are not diagnostic unless marked, and in this collection only two spoons have identifiable marks. Home education supplies including slate pencils, wooden pencils, slate boards, pen parts, etc., also are not included in the detailed analysis because they have little diagnostic or comparative potential.

The artifacts separated for detailed study were pulled out of their lot bags. The artifacts were already in small zipper-closed plastic bags but were sorted into separate bags when necessary. A tag indicating the lot number, provenience, artifact type, and number of specimens enclosed in a plastic envelope was placed in each bag. The artifacts were then grouped by type so that the contents of each group could be determined. 


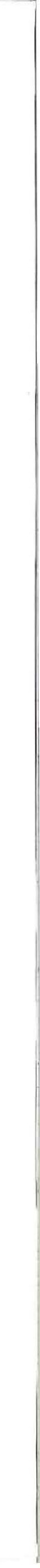




\section{HISTORY OF FANTHORP INN}

Sue Moss

Early visitors to Texas were seldom complimentary in their views of transportation or accommodations in Texas. Roads were primitive, obstacles frequent, and conditions unpredictable. Travelers took their ease wherever they could in the very earliest days of the Republic, and most often found themselves in the cramped $\log$ houses of early settlers. By the eve of the Civil War, however, most towns in Texas had one or more inns or taverns that took paying guests on a regular basis, and for the most part accommodations had improved. Fanthorp Inn in present-day Anderson probably started out as one of those hospitable homes that were open to early travelers. Unlike most, however, it grew to be a well-frequented inn, and by 1860 its host called himself an innkeeper. The Fanthorp Hotel was a stopping and lodging place for a number of Texas notables. Most guests, however, were ordinary Texians going about their daily business.

\section{EARLY YEARS AT FANTHORP}

Henry Fanthorp, the man who built and operated the Fanthorp inn, had arrived in Texas by 1832 , approximately 40 years old and twice a widower. In May 1832 he contracted with Francis Holland, one of Austin's Three Hundred, to purchase a portion of Holland's grant. Holland agreed to sell a quarter league (approximately 1,107 acres) on the east end of his tract to Fanthorp for "Seventy-one dollars and sixty-one cents paid in hand also one mare at one hundred dollars first April next twenty-eight and thirteen cents to be in store goods or other good property and one hundred dollars whenever said Holland make said Fanthorp a Warranty Title" (Buffington Family Papers). The two men bound themselves to go to San Felipe as soon as possible to make the transaction. Joshua Hadley, mentioned by the chief chronicler of Montgomery County as the man Fanthorp boarded with, witnessed the contract. While various sources say, probably correctly, that the Holland-Fanthorp land transaction was completed in 1833 , the deed was not recorded until August 9, 1837, in Washington County. Washington County encompassed Grimes County at that time (Allen 1957:29; Grimes County Deed Record A2:284; Montgomery 1975:166; Rochelle 1936; U.S. Bureau of the Census 1850b; Zuber 1903:7).

As well as owning land in Austin's colony, Fanthorp applied for admission to Sterling C. Robertson's Nashville Colony. On January 21, 1834, Robertson issued a certificate to Henry "Phanthorp" at Tenoxtitlan (Robertson 1834). Eight days later J. S. Black, an early Grimes County settler and Robertson's agent, noted that he had given certificates to 25 colonists; the first on the list was Henry Fanthorp (spelled correctly this time). Also on the list were other names significantly associated with Fanthorp and Grimes County history: Francis and Tapley Holland and Michael Kennard (Black 1834).

According to generally accepted Grimes County lore, Fanthorp built a corncrib soon after acquiring Holland's quarter league and began dealing in corn, buying cheap in the summer and selling dear in the late winter when corn stores were scarce. He used the crib for what shelter he needed and stored corn in the rest. By 1834, however, he had built a more conventional home and brought his new bride to it. Henry Fanthorp and Rachel V. Kennard (Figure 3) were married on February 16, 1834, by Daniel Parker, a Baptist minister and uncle of Cynthia Ann Parker. Rachel Kennard was the daughter of Anthony D. Kennard, who had come to Texas in 1832 and settled in what is now Grimes County. Twenty-three years younger than Henry Fanthorp, Rachel was 20 years old when she became 

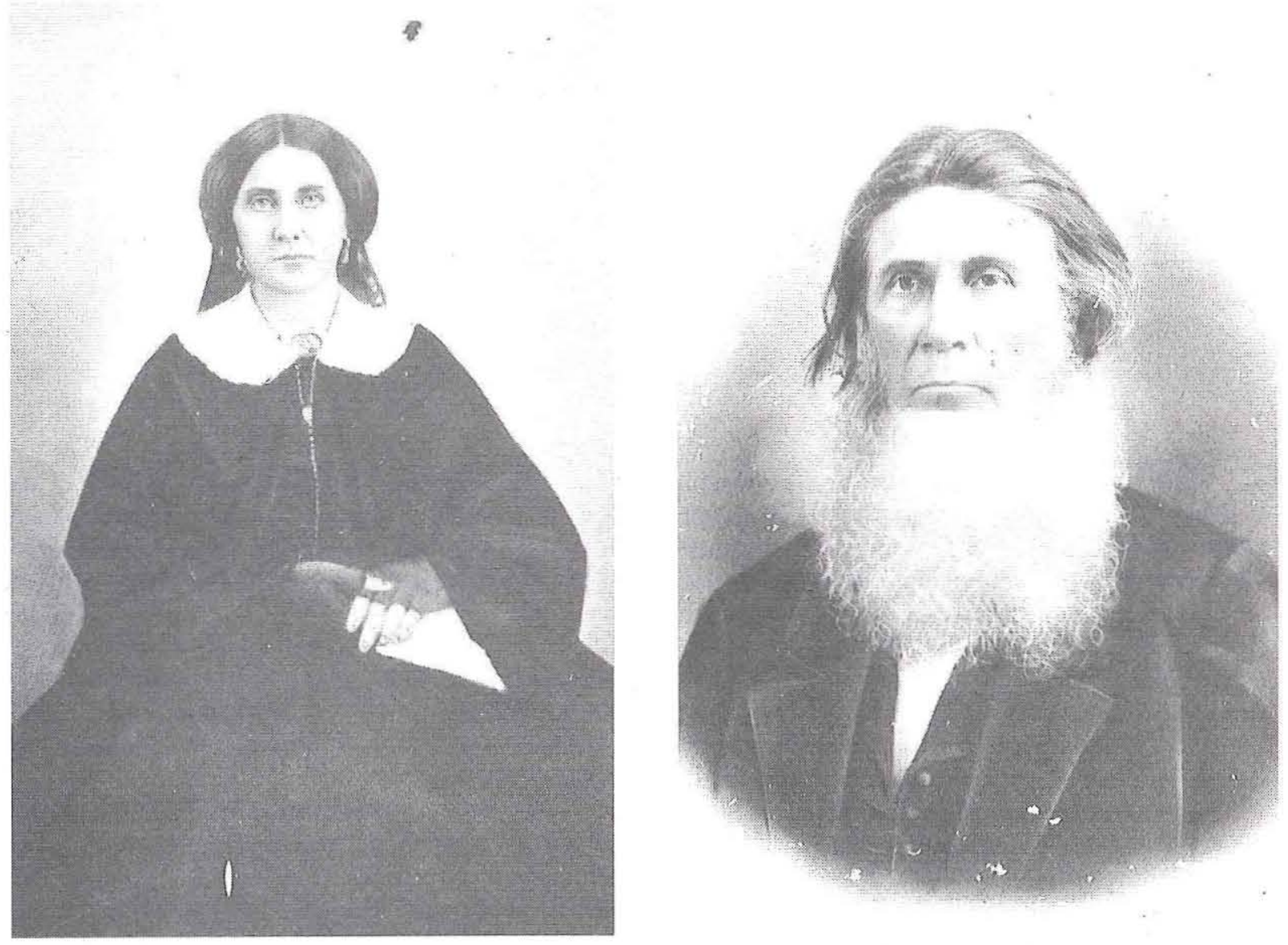

Figure 3. Rachel Kennard Fanthorp and Henry Fanthorp, dates unknown.

his third wife (Allen 1957:29-30; Blair 1930:116124; U.S. Bureau of the Census 1850b; Zuber 1903:7-9).

Henry Fanthorp may have had a mercantile operation in his home or nearby early in his residence in Grimes County. A credit ledger and "daybook" in the Fanthorp Inn Records date from 1832 and contain general merchandising accounts. The daybook with entries from 1832 to 1837 most likely contains the business accounts of a T. B. Wood, whose name appears throughout as creditor (Fanthorp Inn Records, Daybook 1832-1837 [\#1]); none of the names are recognizable as Grimes County residents (the only name with any connection to Grimes County or to Henry Fanthorp is M. D. Moore with one entry; Moore was the maiden name of Rachel Kennard's mother). The credit ledger, however, dated 1832 to 1838 , definitely originated in the area (Fanthorp Inn Records, Credit Ledger 1832-1838 [\#10]). While it is not obvious that the early entries (1832-1833) are from a merchandizing enterprise of Henry Fanthorp, they well could be. The later entries, 1837 to 1838 , are, however, in all likelihood, retail and boarding accounts held by Fanthorp. Names well known in the area appear in these early accounts including Francis Holland, Everton Kennerly, Levi Taylor (whose estate Fanthorp would administer), John S. Black, Anthony Kennard, Joshua Hadley, Tapley Holland, David Lawrance, and John Lawrance. These customers bought tobacco, whiskey, and what were noted as "Sundry Artikles." Some paid in cash and others bartered livestock and goods. There is one early entry in the credit ledger to Henry Fanthorp himself. On page one, June 31, 1832, H. Fanthorp bought one silk handkerchief for $\$ 2.00$ and $23 / 4$ yards of cotton for $\$ 2.051 / 4$. One other informative item from the pre-Republic era is found in this ledger when Fanthorp noted that on August 6, 1834, "Joseph are Nandes [Hernandez?] commenced to tend my stock." Fanthorp paid him in merchandise in March 1835: two steers, gloves, and a piece of calico.

According to the traditional history of Grimes County, Fanthorp's home became a natural stopping and lodging place for travelers. Fanthorp was named 
postmaster in 1835 when the pre-Republic Provisional Government established a weekly postal route between San Felipe and Nacogdoches. The post office took his name and was known as Fanthorp's (the designation of the post office causes some confusion between the man and the place in the early records) (Blair 1930:121-122; Richardson 1940:952; Zuber 1903:10-11).

Henry Fanthorp's support of the Texas revolution in 1836 was multifaceted. In early March, after the Declaration of Independence had been signed, volunteer troops gathered in Washington-onthe-Brazos to swell the Republic's army and expel the Mexican forces from Texas. Fanthorp's inn was on a well-traveled route to Washington, and Anson Jones, who would later be the last President of the Republic, passed the night of March 7 with Fanthorp. ${ }^{1}$ William P. Zuber, en route to Washington with William Kennard (Fanthorp's brother-in-law) to join the volunteers, stayed the night of March 8. Fanthorp enlisted in the new Republic's army in March 1836, although where or how he served is not known. He supplied "two Beaves delivered to the Volunteers on their March to Head Quarters of the Texas Army" on August 13, 1836, at Good Spring Prairie, and he loaned the fledgling government $\$ 700$ (Texas. General Land Office. Bounty Land Records, Henry Fanthorp Bounty Land Grant, Montgomery County No. 90; Texas Treasury Department. Public Debt Records No. 7657, May 28, 1838; Zuber 1971:4546).

The years immediately following the revolution were busy ones for Henry Fanthorp. Between 1837 and 1840, he set up the enterprise that lasted until his death in 1867. Innkeeping, his principal occupation and the one for which he is best known, was well developed during this period. Entries in a credit ledger of the period indicate that Fanthorp's was a stopping place for many travelers (Fanthorp Inn Records, Credit Ledger 1832-1838 [\#10]). Some stayed overnight, others took a meal, and still others boarded and lodged there on a regular basis. Fanthorp in 1837 and 1838 charged $\$ 2.00$ to accommodate one man with one horse for one night and two meals. His fees were double the more usual charges of $\$ 1.00$ to $\$ 1.25$ at other Texas stopping places. As was common for the time, Fanthorp advanced considerable credit to some of his patrons: He rendered a bill for a Mr. Call from February 23,

${ }^{1}$ For Anson Jones's own recollections, see Jones (1859:14-16); he does not mention stopping at Fanthorp's, although Zuber (1971:45-46) mentions Jones being there.
1839 , to July 29,1839 , for 248 meals at a total cost of $\$ 93.00$ (Garwood 1956:224).

While Fanthorp listed no menus, a perusal of his purchases indicates to some extent the fare he offered. The coffee, salt, and syrup he bought were staples of every Texan's diet, but the frequent purchases of flour (most likely wheat), sugar, allspice, and ginger and occasional purchases of apples and raisins show that there may have been more variety at Fanthorp's hotel than in most places on the Texas frontier. Along with these foods, he probably gave his customers pork, tough beef, sweet potatoes, and corn bread, those items most frequently found on Republic tables (Fanthorp Inn Records, Credit Ledger 1839 [\#11], Daybook 18391840 [\#2]; Hogan 1969:31-38).

During this period, Fanthorp also embarked on (or expanded) a retailing venture. About 1837, he formed a partnership with Michael Kennard, his brother-in-law, and Abraham M. Womack, Kennard's father-in-law, to sell general merchandise. The store was likely not part of the inn but occupied a separate structure on the Fanthorp property. While some traditional local sources have said that the store only operated about a year, surviving Fanthorp papers indicate that it was a going concern from 1837 through 1840. A number of people were listed as receiving credit (a customary business practice), including the three principals. The store dealt in merchandise of every assortment. Commodities included flour, sugar, spices, apples, coffee, dried fruit, molasses and "Bread water" (probably leavening). Dry goods were suspenders, shoes, thread, calico, chintz, "apron check," "Domestick," and "negro sheeting." Other items purchased there by Grimes County residents were a sidesaddle, saddletrees, nails, blacking (probably for leather products), crockery, cutlery, tack, and tobacco. The store also served whiskey and other spirits by the drink, "ginger cakes," and crackers. The enterprise, known as H. Fanthorp, A. M. Womack and Co., also bought and sold corn from local farmers, continuing Fanthorp's earlier enterprise. In the fall of 1837 the firm paid from $\$ 22.50$ for $901 / 2$ bushels of corn to a high of $\$ 67.50$ for 100 bushels. As well as dealing in these common goods, the store also paid bounties for wolf scalps during January 1840 (Allen 1957:30-31; Fanthorp Inn Records, Credit Ledger 1832-1838 [\#10], Credit Ledger 1839 [\#11], Daybook 1839-1840 [\#2]; McDonald n.d.; Zuber 1903:11).

The post office at Fanthorp's, as the Fanthorp store-inn complex was known, had been established in 1835 and continued in operation with Henry 
Fanthorp as postmaster through 1840. Recommended by Daniel Parker, Fanthorp was one of the first Republic postmasters. Postmasters were appointed by the Republic's Postmaster General who also awarded the mail-carrying contracts. They were charged by law to keep the post office open to receive incoming and outgoing mail and "at all reasonable hours, on every day of the week, to deliver on demand" any mail. They also collected postage $(61 / 4$ cents per single sheet per 50 miles in $1837 ; 12^{1 / 4}$ cents per single sheet per 40 miles in 1840). As compensation, postmasters received a commission on the postage: 25 percent on the first $\$ 100$; 20 percent on $\$ 100$ to $\$ 300 ; 10$ percent on $\$ 400$ to $\$ 2,000 ; 5$ percent on any sum over $\$ 2,400$. (Why these figures have holes is a mystery-it occurs both in the 1837 and 1841 legislation.) Fanthorp's was midway on Route No. 1 from San Felipe to Randolph, the first leg of the postal run from San Felipe to the Sabine River, a route similar to the earlier Provisional Government's route. He received the mail from Washington and sent it on to "Kennard's" seven miles away. ${ }^{2}$ (This was probably his father-in-law Anthony Kennard.) (Day 1966:3334, 1967:10-11).

The year 1836 was marked by political and military turmoil in the Republic, and the mails often reflected this. Fanthorp noted these circumstances as he sought to bring his records up to date in mid 1837. "Sir," he wrote the Postmaster General, "The confusion occasioned by the invasion of our country prevented me from making my returns regularly. I now send you transcripts of all proceedings of my office since the commencement" (Fanthorp 1837). While not all of Fanthorp's quarterly returns and other post office records have survived, scattered returns and references indicate that Fanthorp's was one of the smaller postal operations in the Republic, serving only its immediate constituency. In October 1839 , the Postmaster General's statement of revenues included $\$ 29.00$ from "Fanthorp's." Of the 69 post offices reporting, Fanthorp's was just above the median revenue, although it only sent 15 percent of the average revenue reported ( $\$ 209$ for 69 post offices reporting $\$ 14,282.54$ ). The system was characterized by several larger volume operations and a number of much smaller post offices like Fanthorp's. In 1839 the route was the 50 miles from Montgomery to Washington via Fanthorp's. The mail was scheduled to leave Montgomery on Sun-

${ }^{2}$ By October 1836 , the postal route changed somewhat and bypassed Kennard's (Telegraph and Texas Register, October 18, 1836). day at 7:00 a.m. and arrive in Washington at 6:00 p.m. on Monday. The return route left Washington at 7:00 a.m. on Tuesday and was to arrive at Montgomery on Wednesday at 6:00 p.m. A similar, if not identical, schedule probably was in effect throughout the Republic period (Day 1966:33-34, 65, 67, $122-123,189,216,1967: 21,31,54-56,64,67,83$, $94,98,130,138,142)$.

At the end of 1840 Fanthorp resigned as postmaster. Just why is not known, but he may have thought to spend his time more profitably at other things. A post office remained at Fanthorp's, however, through the Republic period and was probably located very near the inn. In January 1841 , T. T. Baker was appointed postmaster and served through January 1844 when C. J. Birdsall was appointed. In January 1845, the Texas Congress approved an additional mail route from Fanthorp's to Crockett through Leona Mills (Daniel 1845; Day 1966:6567, 122-123; Postmaster General 1844).

Little is known of Henry Fanthorp's politics during the early Republic period, or during any time for that matter. In 1837 he was appointed one of the commissioners to select a county seat for newly formed Montgomery County, attesting to his political or community standing in the area (Gammel 1898:I:1375-1376). He presumed an acquaintance with President M. B. Lamar when he wrote to His Excellency in November 1839 to "introduce to your acquaintance Mr. Uriah F. Case a citizen of our county who has resided with me upwards of two years past ..." (Fanthorp 1839). Case was leaving Fanthorp's to seek his fortune in Austin, and Fanthorp recommended him for a government job. Lamar's response is not noted although Case was back in Grimes County retailing general merchandise by the late 1840 s.

In 1842 Henry Fanthorp hosted a meeting of area Freemasons in the Fanthorp inn to form a lodge. Joshua Hadley, David C. Dickson, and George M. Patrick were among the Master Masons who met to form the Orphan's Friend Lodge No. 17. Fanthorp was elected treasurer of the group. The lodge soon moved to their own building on Fanthorp's property. In 1846 Fanthorp sold the ground on which the lodge was standing to the lodge for $\$ 1.00$. The area was described as "Seven Hundred and fifty square feet of land situated at Fanthorps town on the plot thereof as follows: Lot No. 4 and South half of lot 3 in Block 2." ${ }^{3} \mathrm{He}$ also

${ }^{3}$ This is probably more correctly measured as 7,500 square feet. The "plot" of "Fanthorps' town" is unknown, but the date is too early for Alta Mira. 
sold them another $23+$ acres in the D. Gregg grant in 1847 for $\$ 2.00$. That Fanthorp was a dedicated Mason is well substantiated through these gifts, and he has even been called the "Father of Grimes County Masonry" (Allen 1957:128-129; Grimes County Deed Record A:17; Marcus Mallard Papers, Transcribed Minutes, Orphan's Friend Lodge No. 17, Kennard Genealogy; Montgomery 1975:256; Wade 1935:65).

By 1845 Henry Fanthorp had begun all but one of his major endeavors in Grimes County, the exception being founding the county seat. According to the county tax records for the year, he owned 1,107 acres in the Francis Holland league, had patented his own bounty grant of 320 acres in Grimes County, and owned another 177 acres, probably in his father-in-law Anthony Kennard's headright. He held two slaves under 10 and five between the ages of 10 and 60 . The slaves had all been acquired since 1840, and six had been bought since 1843. He had one horse at stud and kept five work horses. He owned one wooden clock and, for some reason, did not list the silver watch and cattle that he had reported in 1843 . He had built his inn and home, and a community was growing up around it. At 54 years old with a wife, son, and baby daughter, Henry Fanthorp was prospering in Texas (Texas. Comptroller of Public Accounts. Ad valorem tax records, Montgomery County, 1838-1845).

\section{HEYDAY}

The town of Alta Mira grew up just north of Fanthorp's inn on the Darius Gregg headright. Just what Henry Fanthorp's influence was on its early development is not known. Grimes County tradition tells that Henry Fanthorp purchased some land from the Darius Gregg land grant adjoining his own property on the north around 1839. Fanthorp is supposed to have platted the property soon after, sold lots to merchants, doctors, and families, and named the town Alta Mira, "high view." Fanthorp's own store may have been located in the little town at one time (Allen 1957:31; Blair 1930:123; Zuber 1903:12).

An examination of the county records has revealed, however, that Fanthorp did not own the town in the early 1840 s, nor is it probable that he platted the town. A plat of Alta Mira exists in the Grimes County records (Grimes County Maps and Plats 1846), and a note on it indicates that Darius Gregg had laid off the town and sold the lots in November 1846 along Fanthorp's northeast boundary. Two streets defined the town's three blocks with 12 lots per block. Each street was 50 feet wide, and the lots had 50 feet of frontage on the street and were 100 feet deep: the little settlement sat on five acres. In all there were few owners, most had several lots. Uriah Case, J. B. Harris, G. N. Patrick, O. H. P. Hill, W. E. Harper, G. F. Lester, and John La Prelle held all 36 lots with the exception of lot nine, block two, which Henry Fanthorp owned. Substantiating Fanthorp's lack of personal involvement in Alta Mira are the deed and tax records for the 1830s and 1840s (Texas. Comptroller of Public Accounts. Ad valorem tax records, Montgomery County, 1838-1845, and Grimes County, 18461847). No property from the $D$. Gregg land grant is listed in Fanthorp's ownership until 1846 when 150 acres appear on the county tax rolls. In 1847, 148 acres from the Gregg tract appear on the same rolls, accompanied by $1 \frac{1}{2}$ town lots in Alta Mira. No doubt, Fanthorp's inn and his merchandising stimulated activity around his complex, and this may account for the local tradition that he encouraged the community's growth. When he gave the land to establish the county seat, and Alta Mira was absorbed by the new town of Anderson, the story may have become confused.

During the last half of the 1840 s, two events at Fanthorp's inn probably overshadowed even important political affairs for the local citizens. The first occurred during the very busy special session of the Ninth Congress convened in Washington on June 16, 1845 , to consider the United States's annexation offer. Kenneth Anderson, vice-president of the Republic and a prominent lawyer-orator from San Augustine, left the Congress before it had completed its business because of illness. He became worse on the trip and died at Fanthorp's inn on July 3, 1845. A native of North Carolina, Anderson had come to San Augustine from Tennessee in 1837. A skilled orator, he held a number of political posts in Texas during the Republic period. He had been District Attorney of the Fifth District in 1843 and was a lawyer in partnership with Thomas Jefferson Rusk and James Pickney Henderson in 1845. Elected as a repre-sentative to the Sixth Congress of the Republic, he was chosen Speaker of the House. In 1844 he declined to. run for President, but was Vice-President on the ticket with Anson Jones. He was buried in the Fanthorp family cemetery on July 4 with full Masonic honors (Connor 1971:154-155; Hogan 1969:152; Jones 1859:353; Richardson 1940:237-238; Rochelle 1936; Texas National Register, July 10, 1845; Zuber 1903:26-27).

As well as tempering local celebration of annexation (agreed to by the Texas Congress the day 
after Anderson's death), the sad event inspired area residents to honor the Vice-President. The area that is now Grimes County was part of adjacent Montgomery County in Republic days. The First Texas Legislature, in response to petitions of western Montgomery County residents, established Grimes County, which included much of present-day Waller County and the western part of Madison County. It provided for the selection of a county seat, which had to be within 7 miles of the center of the county, to be called Anderson in honor of the late VicePresident (Gammel 1898:II:1356, 1431; Zuber 1903: 27-28).

The Legislature fixed the first Monday in June 1846 as the date of election of the county seat and appointed S. G. Devereux, Albert G. Perry, Henry Fanthorp, James W. Barnes, and Daniel T. Dunham to lay out and sell lots and to carry out the winning proposal. For whatever reason, the election did not sufficiently fix the site, and the Second Legislature in 1848 passed a similar bill calling for a county seat election on the first Monday in May 1848 and naming the County Commissioners Court to be in charge. The 1848 act was also more specific in allowing the county to sell donated land and use the proceeds for county buildings (Gammel 1898:II: 1432, III:38-39).

Henry Fanthorp's role in determining the county seat siting is not very clear. He was a major contender, and his land just north of Alta Mira was finally selected. Before the 1848 election, Fanthorp, Michael Kennard, and William Berryman (son-inlaw of Francis Holland) provided bond to A. H. Perry, Chief Justice of Grimes County, to fulfill their plan for the location of the county seat (Texas. Secretary of State 1848). If the site was located on Fanthorp's portion of the Darius Gregg headright, the three agreed (1) to donate 133 acres of that headright to the county, (2) to donate 100 acres "lying in the Pinery" near William Patrick's sawmill, (3) to donate the timber on 50 acres within $1 \frac{1}{2}$ miles of the first tract and (4) to provide "a public well to be dug upon the town tract." Henry Fanthorp was to receive, after the county commissioners had surveyed the lots, either every alternate lot or half the proceeds from the sales of the alternate lots. This bond was probably secured to show good faith on the part of Fanthorp and his fellows since it was to be valid only if the county seat was located on the Fanthorp property. Fanthorp owned the 130 acres of the Gregg tract; it may be that Berryman and Kennard owned the other property and timber mentioned. Or it may be that the whole enterprise was Fanthorp's and the other two were only pledging to secure his bond. When the county finally accepted Fanthorp's property as the new county seat, the arrangements were a little different from those in the bond. Fanthorp made a warranty deed on June 24, 1848, to Jno. Graves, Chief Justice of Grimes County, for 139 acres in the southwest corner of D. Gregg's headright. He received $\$ 1$ for the sale and reserved one-third of the proceeds of the sales of the lots (Grimes County Deed Record A:350).

All of the electioneering and politicking between the legislative action and the final selection is not known. According to the county tradition, three sites were offered in the election, and local historians have noted that each of the three held a free dinner and offered other entertainment on election day as voting inducements. Fanthorp's proposal received the most votes in both elections (Allen 1957:34; Blair 1930:28-29; Zuber 1903:28).

The new county seat of Anderson was established adjoining Alta Mira and very near the Fanthorp inn itself. In December 1851 the Fourth Texas Legislature passed an act incorporating Anderson and providing for a mayor, five aldermen, a tax collector, and a constable. Its limits were described as $1 / 2$ mile from the courthouse in any direction. Four and one-half years later, the Sixth Legislature passed virtually the same incorporation bill. Why it took two acts is not known. A mayor and aldermen were presiding in 1853 (Beardsley 1853; Gammel 1898:III:1051, IV:630).

During the decade and a half before the Civil War, Anderson developed into a thriving town incorporating the older settlements of Fanthorp's and Alta Mira. The major commercial enterprises centered around the courthouse square after the stone courthouse was built in 1850-1851. In 1853 A. S. Beardsley, a shopkeeper for Case and Wilson from Connecticut, wrote his sister that there were "about 500 or 600 population in our City." Within the corporate limits were "about 50 families .. .8 stores (dry goods) 4 Groceries 3 Waggon Makers Shops 3 Black Smith Shops I Gun Smith 2 Tailors 2 Hotels 2 ten Pin alleys and about 20 Carpenters in constant employment (we are to have a new Babtist [sic] Church in this City ... .) the Episcopalians expect to build soon . . . they will probably build larger than the Babtists. . . ." Certainly this is a picture of a bustling town (Allen 1957:38; Beardsley $1850,1853)$.

By 1855 the Anderson Baptist Church had built its stone building, Methodist and Episcopal churches were organized, and several schools had been formed including St. Paul's College (Episcopal). 
The Orphan's Friend Masonic Lodge had established the Fanthorp's Masonic Collegiate Institute in 1846, but discontinued it in 1851 in favor of St. Paul's College. Henry Fanthorp, with Anson Jones and Grimes County residents B. B. Goodrich, George M. Patrick, and D. C. Dickson, was among the trustees of the school which opened on January 1 , 1852. Though the college attracted many area students, especially in its preparatory school, it closed in 1856. Anderson also had a girls' school, the Anderson Female Institute. Fanthorp's son John Henry attended the coed Masonic Collegiate Institute, and the later St. Paul's College. Mary Fanthorp attended the Anderson Female Institute (Allen 1957:102-105, 112-115, 132-136; Carter 1963: 169-176; Charles Gillette Papers, List of Boys Attending St. Paul's College, June 30, 1852; James Lawrance Papers, Lists, Fanthorp's Masonic Collegiate Institute, March 12, 1849, September 3, 1849, January, no year).

The religious affiliations of the Fanthorp family are not known. The Kennards were active in forming the Baptist congregation in Anderson. Rachel Fanthorp's mother, Sarah Kennard, was a member of the Baptist Church. Henry Fanthorp, from England, was likely Episcopalian, particularly considering his involvement with St. Paul's College on behalf of the Episcopalian Church (Allen 1957:103).

In the mid 1850s Anderson had two newspapers, the Central Texian and the Texas Baptist. They and their advertisements reveal much that was happening in Anderson at the time (Central Texian, March 17, 1855-March 7, 1857; Texas Baptist, May 2, 1855-October 25, 1860). In 1855 through 1857 , at least four medical doctors advertised, as well as a traveling dentist and an "oculist and aurist" (an eye and ear doctor) who had an office at "Fanthorp's Hotel." At least 11 attorneys practiced there, lured no doubt by its location as the county seat. Besides a number of pharmacies, groceries, and dry goods emporia, a wide variety of other goods and services were available, including piano lessons and tuning, dance lessons, cabinet-making, millinery, wagon-making, blacksmithing, daguerreotypes (from an itinerant photographer), watchmaking, and silversmithing. Local industries included steam saw and grist mills, a "Tin, Copper and Sheet Iron Manufactory," a "Sash, Door and Window Blind Manufactory," and a boot and shoe maker. Local entertainments were touted and announced as well. The Young Men's Debating Society, three Masonic lodges, two chapters of the IOOF, local political gatherings and speeches, music recitals, and school commencements were all advertised in Anderson during this time. One of the most unusual entertainments must have been a traveling show scheduled at the Anderson Hotel on April 11, 1858. "To commence at early candlelight," the show included a Solar Lantern show, "a variety of Star Chromatropes" and, as a finale, a polka danced by "The Dwarf Sisters, Misses Emeline \& Amanda Jones" (Texas Baptist, April 8, 1856). Admission was 50 cents with children and servants at half-price. Anderson, by all accounts, was a thriving town before the Civil War.

During Anderson's heyday, Fanthorp's Hotel enjoyed the boom, catering to travelers and local customers alike. In the mid 1850 s stage lines ran through Anderson (Figure 4). From Anderson a passenger could go to Houston, Huntsville, Washington (-on-the-Brazos), Springfield, or Crockett, or eventually to San Antonio, Corpus Christi, or Stinson's Ferry on the Neches. Fanthorp's books for 1847 to 1851 contain a schedule beginning September 26, 1848, for the A. Houston \& Brooks stage line from Washington to Huntsville and also have the following notation, "Commenced to take Care of the Stage 1850 July 1 the Stage commenced the Line" (Fanthorp Inn Records, Daybook 1847-1851 [\#3]). Between 1851 and 1859, at least, Fanthorp was also an agent for the United States Mail Coach Line. He was listed in its advertisement in January 1851. The line ran twice a week from Houston to Austin. Through fare was $\$ 15$ per person. Leaving Houston at 4:00 a.m. each Wednesday and Saturday, the coach arrived at Austin on Monday and Friday at 9:00 p.m. The coach was to leave Austin "the same hours and same days it leaves Houston, and arrives at Houston the same hours and days it arrives in Austin." Agents of the line included J. M. Reynolds, Houston; A. Hood, Independence; H. Boyle, La Grange; Capt. James G. Swisher, Austin; Henry Fanthorp, Anderson; Mr. Ousman, Washington; Mr. Compton, Brenham; J. H. Gillespie, Bastrop; and Leonidas C. Rountree, Huntsville. "Safety, speed and comfort" was the motto of the company. Another stage line that probably stopped at Fanthorp's hotel in 1859 was one owned by G. W. Grant that ran from Anderson to Waxahachie via Kellum's Springs, Madisonville, Leona, Centerville, Fairfield, Flowerdale, and Corsicana, leaving Anderson Monday, Wednesday, and Friday at 5:00 a.m. A special coach made the trip daily from Anderson to a nearby popular resort, Kellum Springs, during "the season" (Allen 1957:72-80; Boulet n.d.; De Cordova 1858:196, 200; Fanthorp Inn Records, Daybook 1847-1851 [\#3]; Texas 


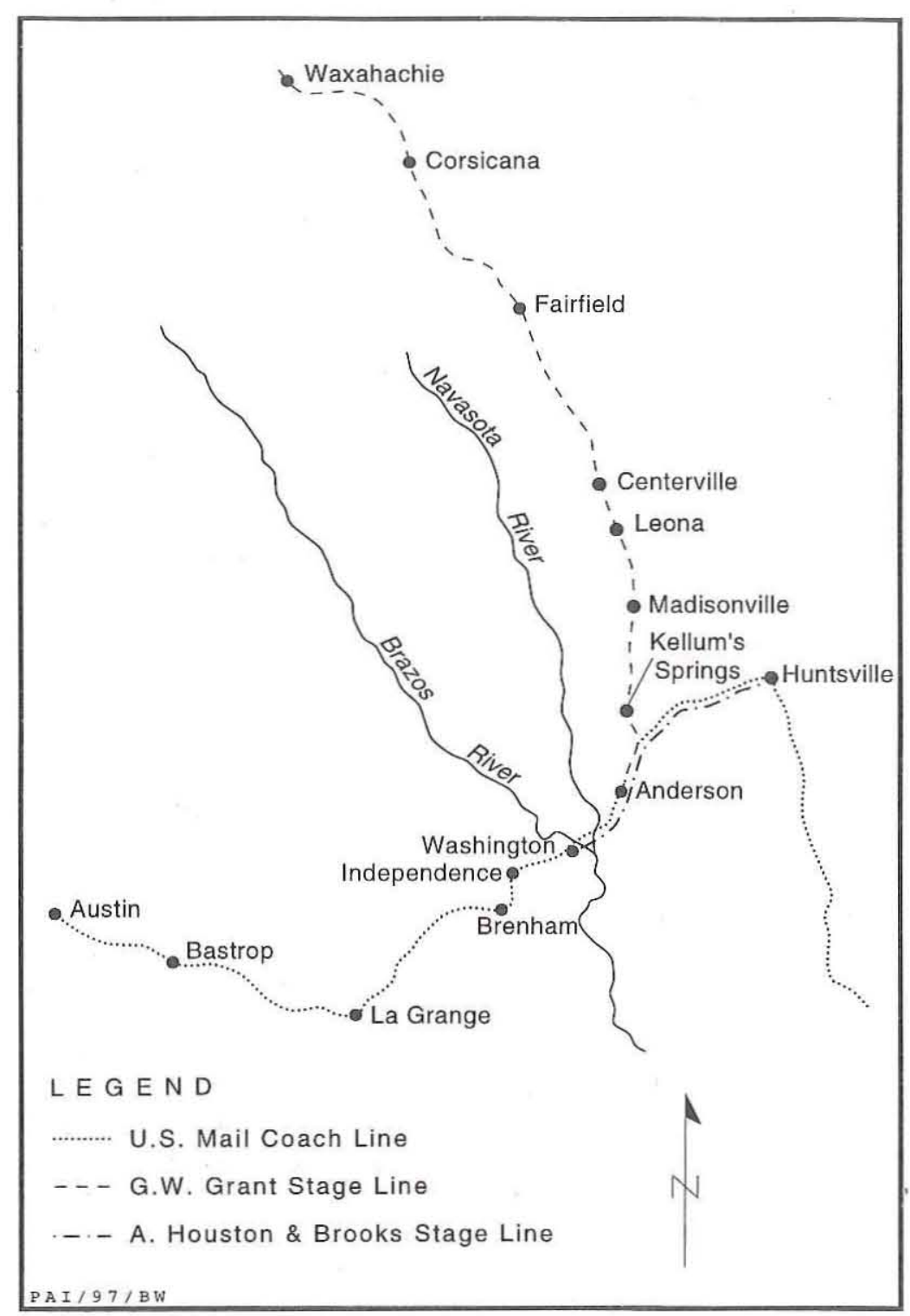

Figure 4. Map of stage lines running through Anderson.

Baptist, July 14, 1859; Texas State Gazette, January 18,1851$)$.

Fanthorp's accounts during the period contain ledgers enumerating passengers, destinations, fares, and collections. One interesting document, undated, listed fares to various places. From Anderson to closeby Navasota, the charge was $\$ 1.25$; to Huntsville, $\$ 3.75$; to Crockett, $\$ 9: 00$; to Rusk, $\$ 14.00$ and to Marshall, $\$ 24.00$. According to his records, Fanthorp changed horses, provided board and lodging to stage drivers, collected fares, and accommodated passengers for meals and overnight. Between 1859 and 1861 he sold tickets for destinations such as Centerville, Waxahachie, Madison- ville, Fairfield, and Corsicana (Fanthorp Inn Records, Daybook 1847-1851 [\#3], Daybook 1859-1862 [\#6], Stage Line Records 1852-1859 [\#26]).

There were other boardinghouses and hotels in Anderson during the 1850s: La Prelle's hotel, Anderson Buffington's Alta Mira House, B. B. Goodrich's hotel, and the Anderson Hotel (first La Prelle's and then sold to J. R. Montgomery and again to L. M. Jones). Fanthorp's, however, was preferred by many for its food. A. S. Beardsley wrote his wife in 1851 that he had switched his boarding to Goodrich's hotel because it was closer to his store; however, he said, "There is not as much company as at Fanthorp's where there is a great rush for the table considerable of the time" (A. Beardsley 1851a). When his wife and son came to Anderson in the fall, however, the Beardsleys lived for a time at Fanthorp's Hotel. Mrs. Beardsley was enthusiastic about the place, calling it "an excellent boarding place, as good probably as the South affords. ... We have a very pleasant Landlady \& a house full of servants, anything we want we can have brought to us in our room by calling for it" (J. Beardsley 1851a). In a subsequent letter she remarked, however, that it had been "too cold to write in my room at Mr. Fanthorp's" (J. Beardsley 1851b; Central Texian, May 30 and October 8, 1856; Texas Baptist, March 18, 1856).

Famous Texans, including Anson Jones, Sam Houston, and Henderson K. Yoakum, appear in the register, and local lore tells of more. Robert E. Lee, Jefferson Davis, and U. S. Grant are reported to have stayed there. Zachary Taylor, marching to Mexico in 1846, is said to have camped near Fanthorp's hotel. He and his officers were treated to an elegant formal dinner in the inn, while his troops were fed under the trees outside. Another illustrious visitor was the Honorable Amelia M. Murray, Ladyin-Waiting to Queen Victoria. Although her book on 
her travels, Letters from the United States, Cuba and Canada (Murray 1856), does not mention stopping in Anderson, a favorite Fanthorp family tradition tells of her greeting Henry Fanthorp enthusiastically as a fellow countryman. She and Mary Fanthorp gathered flowers for her souvenir collection (Fanthorp Inn Records, Register 18521854 [\#20], May 29, 1852, October 8, 1853, p. 32; Garber 1954; Obercamp n.d.:2).

Most visitors at the inn, however, were not famous. In the summer of 1850 when the U.S. Census was taken, the residents of the hotel were listed. There were the lodgers who considered the inn their home: blacksmith J. C. Dickey; Dr. E. W. Belding; three carpenters, George Wistern, John W. Gray, and C. C. Lyton; J. L. Dickson, Morris Levy, and Isaac Coleman, merchants; and two stone masons, Anthony Hopper and J. M. Warren. These men were from many places: northern and southern United States, Scotland, Poland, and Ireland. The 1860 census showed G. W. Mooring, the county clerk; George Ehrensfort, a laborer; and four stage drivers, Peter Plumm, R. Pittman, Dan Lee, and J. W. Thompson (U.S. Bureau of the Census $1850 \mathrm{~b}$, 1860b).

Fanthorp's charges were standard for the period. During 1847 he charged $\$ 1.00$ per day for board and lodging. In 1848 the price was the same with supper only at 25 cents and a full month's board at $\$ 8.331 / 4$. By November 24,1851 , however, he charged Beardsley $\$ 10$ per month to board for supper. Later in the decade prices probably rose at the hotel, if hotel prices at other places in town are any indication. The Anderson Hotel charged $\$ 20$ per month for nonlodgers to board, and James E. Paxton's boardinghouse charged $\$ 12$ for the same. The Anderson Hotel (now under Anderson Buffington) charged $\$ 1.00$ for one day's boarding and lodging and 50 cents per meal (Fanthorp Inn Records, Daybook 1847-1851 [\#3]; Texas Baptist, January 27 and March 24, 1859).

Taking into account the scanty records for the period and descriptions of the fare, little had changed since the Republic period. Fanthorp bought raisins, whiskey, molasses, brandy, flour, peppers, port wine, chickens, beef, venison, turkeys, rice, butter, potatoes, tea, mustard, salt, coffee, cheese, sugar, and mackerel, as well as candles and "sope" for his household and probably for his patrons as well. "The living [at the Fanthorp hotel] is entirely different from what I have been used to," Beardsley wrote to his family in mid December. The "living" that he went on to describe was the food:

\begin{abstract}
We have in the Morning Coffee strong enough to bear up an iron wedge and Fresh Pork Fresh Beef Roasted \& Broiled \& for Dinner we have the same $\&$ for Supper the same. Sometimes we had in addition a little Chicken, Turkey ... a few times a hard looking kind of Apple Pie \& sweet Potatoe Pie. I wish I could describe them to you but it is impossible. For Bread we have warm biscuits \& Corn Bread. We have had a few times light Bread. It is a great luxury. Butter we have had none on the table for the last week but that is of no consequence for when we did have it, it was so poor I could not eat it [Beardsley 1850].
\end{abstract}

Though Beardsley had rued the lack of milk and butter in December, by February it was on the table, and the coffee was palatable to him with milk in it (A. Beardsley 1851b, 1851c). Negro slaves did the cooking and used cast iron ovens in the fireplace (Fanthorp Inn Records, Daybook 1847-1851 [\#4], Daybook 1854 [\#5]).

The accommodations, however, had changed since the early days. A major enlarging of the inn took place in late 1850 when, according to Beardsley (1851c), Fanthorp "raised his [house] two stories high recently \& put up another house adjoining this." He probably more than doubled his accommodations with this addition. In late 1855 Fanthorp may have put another addition on the inn, increasing its size even more. Invoices dating to the summer and fall of 1855 in the Fanthorp records list large quantities of planks, shingles, ceiling boards, and framing boards. The inn registers, confusing for more than one reason, indicate a number of visitors, but it is impossible to decipher how many stayed at one time (Fanthorp Inn Records, Register 18521854 [\#20], Register 1854-1855 [\#21], Register 1858-1860 [\#22], Register 1860-1861 [\#23], Stage Line Records 1852-1859 [\#26]; Scott 1856).

Life for the Fanthorps was not all work at the inn and for the stage line. Most inns in antebellum Texas were the centers for community social life, and Fanthorp's was no exception. Balls and parties were held at the hotel, and Beardsley described one rather lavish affair held there in 1851:

We had a great Ball at Fanthorp's Hotel Monday the 21st called the Battle of San Jacinto in commemoration of 
the day ... there were probably 150 or more at the Ball \& Mr. \& Mrs. Fanthorp took all pains in their power to get the supper up in good order \& style \& succeeded beyond my expectations if they had had nice furniture \& crockery it would have been hard to beat they had good variety for Texas! \& it was well cooked the fair sex present were the most of them good looking \& dressed in good style \& taste the dancing on the whole was very good [A. Beardsley 1851a].

The Fanthorps had a piano after 1857 at least, which was no doubt well used on these occasions (Garwood 1956:223-234; Gillette 1851; Texas. Comptroller of Public Accounts. Ad valorem tax records, Grimes County, 1857).

The highlight of the decade before the Civil War for the Fanthorp family was probably the trip they made to England in 1854. Son John Henry Fanthorp, 14 years old at the time, the elder Henry, Rachel, and 10-year-old Mary left around the first part of June. They returned in mid September. While in New York en route to England, Fanthorp ordered a carriage made (Beardsley 1854a, 1854b; Fanthorp 1857).

During the late 1840 s and first years of the 1850 s, Fanthorp was again (or still) in a merchandising partnership with Michael Kennard, his brother-in-law. A ledger in the Fanthorp Inn Papers covering 1847 to 1852 contains the accounts of the firm "Kinnard [sic] \& Fanthorp Alto Mira Texas Commenced in the year of our A D 1847" (Fanthorp Inn Records, Daybook 1847-1852 [\#4]). The first entry is dated May 22, 1847, and starts a day-by-day account of sales. The firm mainly dealt in grocery staples such as sugar, flour, rice, spices, molasses, coffee, and tea but also handled lemons, potatoes, cakes, castor oil, quinine, raisins, cheese, soap, matches, cigars, nails, and some dry goods. Spirits were available by the drink, quart, or gallon. The last sales entry is dated May 18, 1848, just one year after the first, but the final accounting in the back of the book is dated October 1, 1852. It seems likely, particularly given Fanthorp's accounts and the various notations that his slaves picked up merchandise, that Fanthorp did not clerk in the store but was a more-or-less nonparticipating partner, and Kennard may have been the actual manager/ operator. In all likelihood the store was not in operation after May 1848. Beardsley's papers speak of Fanthorp, and they speak of stores in Anderson and Alta Mira in 1850, but they do not mention a Fanthorp or Kennard store.

As well as merchant and innkeeper, Henry Fanthorp was also a farmer. By 1850 he had acquired over 2,800 acres of land in Grimes County, primarily in the Francis Holland, William E. Kennard, and A. D. Kennard land grants, his own 320 -acre bounty donation, and seven lots in Anderson. He had various horses and work animals and ran 250 head of cattle, 200 sheep, and 60 hogs. His cattle must have provided butter for the hotel table since the U.S. census for 1850 showed that he had produced 365 pounds of butter during the previous year. The $\$ 425$ value of animals slaughtered indicates that his cattle and hogs were also found on the inn table. His two hundred sheep produced 500 pounds of wool, one-eleventh of the total Grimes County wool crop for the year from one-twentieth of the total sheep in the county. To mark his livestock, Fanthorp registered his brand and marks: cattle-underbit in the right ear; hogs and sheep - underbit in the right ear and hole in the left ear (Grimes County Marks and Brands Book 1, March 7, 1849). Fanthorp had listed his occupation in the 1850 population census as farmer and grew the common foodstuffs of the area: 2,000 bushels of corn, 30 bushels of oats, 10 bushels of peas and beans, 30 bushels of Irish potatoes, and 50 bushels of sweet potatoes. He harvested 400 pounds of honey and produced 8 bales of cotton. Except for a higher-than-average ratio of Irish to sweet potatoes and sheep to cattle, Fanthorp's production was much like that of the county as a whole (Texas. Comptroller of Public Accounts. Ad valorem tax records, Grimes County, 1850; U.S. Bureau of the Census 1850a, 1850b, 1853:512-519).

Fanthorp's household in 1850, besides his boarders, included his wife Rachel, 36, and his two living Texas-born children, John, 9, and Mary, 5. He was 59 at the time and held 14 slaves. Fanthorp estimated the value of his property, both real and personal, at $\$ 6,800$. By 1860 when he was almost 70, Fanthorp had become a prosperous man. He valued his real estate holdings (1,300 acres according to the census and 3,500 acres according to the tax rolls) at $\$ 50,000$ (tax roll value was $\$ 36,000$ ). He also noted $\$ 35,000$ worth of personal property, most of which was in his slaveholdings. The household except for boarders included Rachel, John, Mary, and 32 slaves (U.S. Bureau of the Census 1850b, 1850c, 1860b, 1860c).

Even though Fanthorp listed himself as a "Hotel Keeper" in the 1860 census, he was still an industrious farmer. His property and slaveholdings 
had increased markedly, and his farm production, for the most part, had grown, too. In 1860 he estimated that the total value of his livestock was $\$ 4,550$ and included 12 horses, 2 asses/mules, 32 milk cows, 10 working oxen, 250 other cows, 320 sheep, and 100 swine. His livestock provided 1,000 pounds of wool and 200 pounds of butter. He raised 4,000 bushels of corn, 10 bushels of oats, no peas or beans, 30 bushels of Irish potatoes, and 100 bushels of sweet potatoes. His white potato production remained the same as in 1850 , but his sweet potato and corn production, as well as his drove of hogs, had doubled, perhaps to keep up with the increase of his slaveholdings and inn guests. The value of animals slaughtered rose from $\$ 425$ in 1850 to $\$ 2,200$ in 1860 , reflecting both increased value and increased number of animals. He also grew 14 bales of cotton, 6 more than the decade before. Fanthorp's cotton output had increased only by 75 percent even though his available work force had doubled. No doubt the slave force was primarily at work at the Fanthorp Hotel (U.S. Bureau of the Census 1850a, 1853:512-519, 1860a, 1863:140-143).

Henry Fanthorp's slaveholdings were acquired gradually. He was first taxed for slaves in 1841, but he may have hired slave help earlier. By 1850 Fanthorp had 14 slaves: 5 females between 22 and 38 ; 3 males, aged 22 to 26 ; and 6 children, aged 4 to 14. In 1855 he had 15 and valued them at $\$ 6,750$. His holdings rose steadily, and in 1860, he had 32 slaves. ${ }^{4}$ The makeup of Fanthorp's slaveholdings in 1860 does not conform to the more family-grouped holdings of most Texas slave owners at the time. There were eight adult females (those over 18) and four adult males. None of the females was over 32 , and only one is of the correct age to correspond to any of the five adult females he held in 1850 . The same is true of the adult men-only the age of one matches up. Among the children, one boy and two girls may have been carried over. So, during the decade between 1850 and 1860 , not only did Fanthorp double his holdings, he also almost completely changed them out. In 1860 he had no

${ }^{4}$ There is some discrepancy in Fanthorp's slaveholdings between the census schedule and tax rolls, and it may be that very young slave children were not considered taxable and are thus omitted from the tax rolls. It is more likely the rolls [the census schedule] listed all slaves, both hired and owned, on the property, and the tax rolls reflected only slaves in ownership. At any rate, both the 1850 and 1860 census reports are higher than the tax reports. Because this paper is concerned with slave residents, I have chosen to use the census counts when possible and the tax reports as supplements for noncensus years. slave over the age of 32 . Four boys were 17 years old, and a girl and a boy were 16; it is unlikely that all were the progeny of slave women on the place. There were 14 children between 2 months old and 14 years. The two youngest, the 2-month-old boy and another boy, 1 year old, were designated mulattoes. A 23-year-old male was listed as a mulatto. The tax rolls show Fanthorp's holdings to have been at 29 in 1862 and 1863 and to have fallen to 26 valued at $\$ 25,300$ in 1864 . In 1860 there were 505 slaveholders in Grimes County out of 799 total white families; only 46 had more than 30 slaves; 327 had less than 10. Fanthorp was among the upper 1 percent of the slaveholders in the county and among the upper 5 percent in the state. The average slaveholding in Grimes County was 10.8 slaves and in Texas, 8.3 (Texas. Comptroller of Public Accounts. Ad valorem tax records, Grimes County, 1846-1866; U.S. Bureau of the Census 1850c, 1860c, 1863:240-242).

During the early 1850 s most of the slaves probably worked at the inn. Mrs. Beardsley provides an enlightening account of life at the inn for the slaves:

They have four Men, five Women \& four Children colored, besides overseer \& hostler, white. A happier set I never saw [than] these negroes are, there is an abundance of everything provided \& they fare just as well as the boarders, I scarcely ever step out on the dining room piazza without seeing one or two little negroes with roast beef, beef steak, Sweet Potatoes or something of the kind in hand \& grease from ear to ear. I suppose all the Slaves in Texas do not fare as well as Mr. Fanthorps. I am told they are better treated than in the old Southern States [J. Beardsley 1851a].

Indirectly corroborating Mrs. Beardsley's assessment of the slaves' treatment are various post-Civil War tax records. In 1867 six freedmen (maybe seven if two were named George) had taken the surname Fanthorp. Taking the former master's name was often a sign of the esteem a slave had for the master. The six were Jake Fanthorp, Jonathan Fanthorp, Kinch Fanthorp, George Fanthorp (listed twice), Peter Fanthorp, and Abe Fanthorp (Genovese 1976:445-447; Texas. Comptroller of Public Accounts. Ad valorem tax records, Grimes County, 1866-1867).

On the eve of the Civil War, Henry Fanthorp 
increased his landholdings by buying the remainder of the A. D. Kennard headright league and another one-third league from his widowed mother-in-law, Sarah Kennard (Grimes County Deed Record D:329). Fanthorp paid her $\$ 12,000$ for the property. Mrs. Kennard also gave to Rachel Fanthorp the slave woman Rose "and her children" which she valued at $\$ 3,000$. Fanthorp did not farm his new property, but rented it out "to some newcomers," according to Mrs. Kennard (Kennard 1860).

\section{CIVIL WAR AND LATER YEARS}

During the Civil War the Fanthorp inn seems to have functioned much as usual, although perhaps at a more hectic pace. Anderson was a center of recruiting in 1861, and according to one witness, recruits there were coming in "pretty fast," perhaps inspired by a ball held at the inn on May 1, 1861. Fanthorp also put up Confederate troops. An undated voucher in the inn papers records that the Confederate States owed Fanthorp $\$ 27.00$ for "Board lodging and attention to Privates, Col. A. P. Bagby's 7th R[egiment] 7 M[ilitary] V[olunteers]." The charge was $\$ 1.50$ per day, and there were probably 18 privates put up for one day to equal $\$ 27.00$. In 1864 about 1,500 Union prisoners camped near Fanthorp's, evidently en route to the prisoner-of-war camp at Camp Groce. A daybook in the Fanthorp papers from 1861 to 1866 records passengers, destinations, and fares and appears to be a continuation of previous records, indicating, if not business as usual, at least a continuing trade in the stage line and hotel business (Fanthorp Inn Records, Confederate States to Henry Fanthorpe [sic] n.d., Daybook 1860-1866 [\#7], Stage Line Records 1852-1859 [\#26]; Howell 1861, 1864; Webb 1952:I:281).

Henry Fanthorp at 71 in 1861 was too old to enlist in the Confederate Army; his son John Henry (Figure 5), however, joined up on December 27, 1862, for a three-month stint with the Texas State Troops, stationed at Camp Lubbock and Camp Anderson. He served less than a month before he died at the Fanthorp inn on January 20, 1863 (Montgomery County Historical Commission n.d.; Texas State Library and Archives, J. M. [sic] Fanthorp, Confederate Muster Rolls). ${ }^{5}$ The young

\footnotetext{
${ }^{5}$ There appears to be a transcription error in listing the younger Fanthorp's date of death in Montgomery County Historical Commission (n.d.) as June 20, 1863. The muster roll corroborates his tombstone with the date of January 20, 1863. The cause of his death is not documented.
}

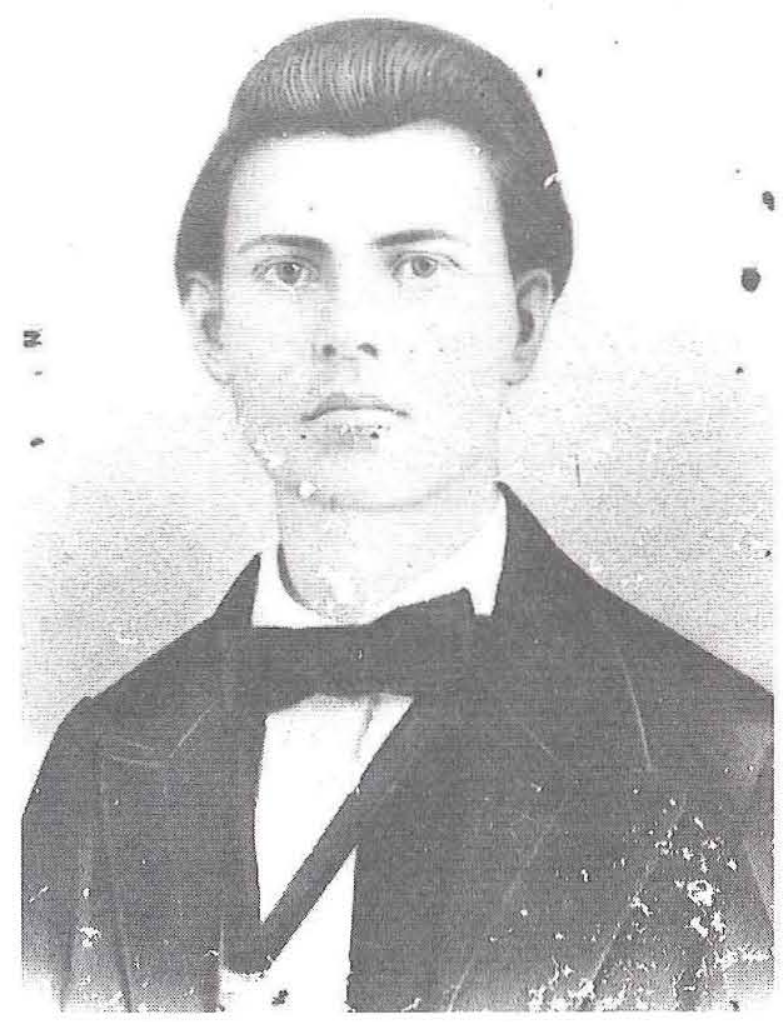

Figure 5. John Henry Fanthorp, first child and only son of Henry and Rachel Fanthorp, born in 1840 and died in 1863. From a colored chalk picture, date unknown.

Fanthorp was married at the time to the former Sallie L. Moore whom he had wed in Anderson on December 24, 1861. After his son's death, Henry Fanthorp gave Sallie Fanthorp 640 acres out of the A. D. Kennard, Sr., headright. Sallie Fanthorp had been born Sallie Moore in Marshall County, Mississippi, in 1824 and had lived in Texas since 1851. She was approximately 16 years older than John Henry. She held three slaves in her own name in the 1863 ad valorem tax rendering and had six in 1864 along with her 640 acres out of the Kennard tract (Texas. Comptroller of Public Accounts. Ad valorem tax records, Grimes County, 1863-1865). The name Moore may indicate a kinship with Rachel Fanthorp's mother, Sarah Kennard nee Moore. In 1865 under the listing of Sarah Fanthorp she had 600 acres of land and four horses. In May 1866 Sallie Fanthorp married E. T. Terrell in Grimes County; they later moved to West Texas, settling near present-day Colorado City, Mitchell County (Grimes County Deed Record D2:444; Texas State Library and Archives, Confederate Pension Rolls, 
Application \#30816, Mrs. E. T. Terrell).

After the Civil War was over, the Fanthorp fortunes declined considerably. Without labor to work his fields, Fanthorp's property valuation in 1866 dropped to almost one-half of the 1860 valuation. He had less than half as many sheep and only two-thirds as many cows. His tax rendering for 1867 shows his property values increasing, but his livestock only half of what it was even the year before (Texas. Comptroller of Public Accounts. Ad valorem tax records, Grimes County, 1860-1867).

Fanthorp's relationship with his former slaves is somewhat chronicled in his papers. He may have contracted with several freedmen to work portions of his property. Such contracts were required just after the war by the Freedman's Bureau, and a fragment of one such agreement remains in the Fanthorp inn papers. The paper bound "the undersigned Freed men and women heretofore the negro slaves of Henry Fanthorp ... now residing on his premises severally for ourselves and our respective children ... to continue to work and labor for the said Henry Fanthorp on his premises and plantation as we have done her(etofore)." The fragment, probably a draft, ends here although $81 / 2$ lines are left on the page. No signatures are affixed. Another loose sheet details the amount of money paid to various freedmen between March and December of the unstated year (Fanthorp Inn Records, Stage Line Records 1852-1859 [\#26], undated contract fragment, undated "Farm Account").

During this period Fanthorp carried on an active trade at a local store, probably that of William E. Stone, his son-in-law. (Fanthorp may have even helped finance Stone's mercantile venture.) During 1866 and 1867 Fanthorp bought merchandise for himself, the inn, his family and " $1 \mathrm{pr}$ shoes for Negro" and "1 Butcher's knife for Peter." Fanthorp also loaned cash to his tenant farmers for necessary expenditures. On one such account Fanthorp advanced "Harrison Miller, freedman" $\$ 23.53$ between January 9 and November 16, 1866. The largest part of the cash advance was $\$ 9.03$ for a coffin and clothes to bury Miller's wife in February, but $\$ 1.50$ was also loaned on January 9 to go to the circus. Miller remarried within the year, and by November 16 Fanthorp had paid $\$ 5.75$ for shoes, snuff, flour, and jeans for Miller's new wife "Rinno" (Fanthorp Inn Records, Daybook 18661867 [\#8]; Daybook 1866-1871 [\#9], p. 4, "Harrison Miller freedman in $\mathrm{a} / \mathrm{c}$ with Henry Fanthorp n.d.; Stage Line Records 1852-1859 [\#26]).

The ad valorem tax list for 1867 lists four freedmen with the surname Fanthorp as property holders. Each had one horse ranging in value from $\$ 10$ to $\$ 60$ and miscellaneous, unitemized property from $\$ 6$ to $\$ 25$. Three other Fanthorp-surnamed freedmen paid only poll taxes and recorded no property. One of these was Peter, perhaps the Peter for whom the butcher's knife was bought; he may have been working in the Fanthorp Hotel kitchen.

The inn was still a going concern after the war. In 1866 and 1867 Fanthorp bought flour, rice, chickens, eggs, oysters, dried apples, lard, bacon, and spices for the inn and his family. He also bought drinking glasses, crockery, candles, chamber pots, and mirrors, probably also for the inn, as well as dry goods, tobacco, boots, shoes, a shawl, hat, ink, a well bucket, and a 14-pound logging chain. $\mathrm{He}$, as well, wholesaled beef and other goods to his son-inlaw's general merchandising store (Fanthorp Inn Records, Daybook 1866-1867 [\#8]).

One item that Fanthorp purchased throughout his years in Anderson was quinine, probably to cure or ward off the various fevers rampant in nineteenth-century Texas. In 1867, however, yellow fever, the scourge of coastal Texas, hit Anderson and may have struck first at the Fanthorp inn. According to the family tradition, a stage driver became ill with yellow fever at the inn, and Mrs. Fanthorp tended him. When he died, Mrs. Fanthorp came down with the disease and was heroically nursed by her sister-in-law, Mary Ann Womack Kennard (wife of Michael Moore Kennard, Rachel's brother). Mrs. Kennard stayed in a small log house on the Fanthorp place for six weeks and nursed Rachel Fanthorp and probably Henry, too. The disease was too potent, however, and Henry Fanthorp at age 77 died on October 31, 1867; Rachel died on November 2 (Grimes County Probate Minutes O:239; Marcus Mallard Papers, Elizabeth Brown Richardson, Kennard Genealogy).

When Henry and Rachel Fanthorp died, their scle heir was their daughter Mary Fanthorp Stone. ${ }^{6}$ She and her husband William M. Stone (Figure 6) became the administrators of the Fanthorp estate. The real property consisted of 2,357 acres of land in Grimes County, three Anderson lots worth a total of $\$ 18,894$ and about 500 acres in various other counties valued at $\$ 2,500$. The personal property of

${ }^{6}$ Henry Fanthorp was the father of at least four children. When applying to the Austin Colony, he listed himself as a widower with a son in England, but nothing more appears about this son. Henry and Rachel Fanthorp's son, John Henry, born in 1840, had died in 1863. Their first daughter, Sarah Elizabeth, was born in 1842 and died in 1844 (Buffington Family Papers, Fanthorp family genealogical material). 

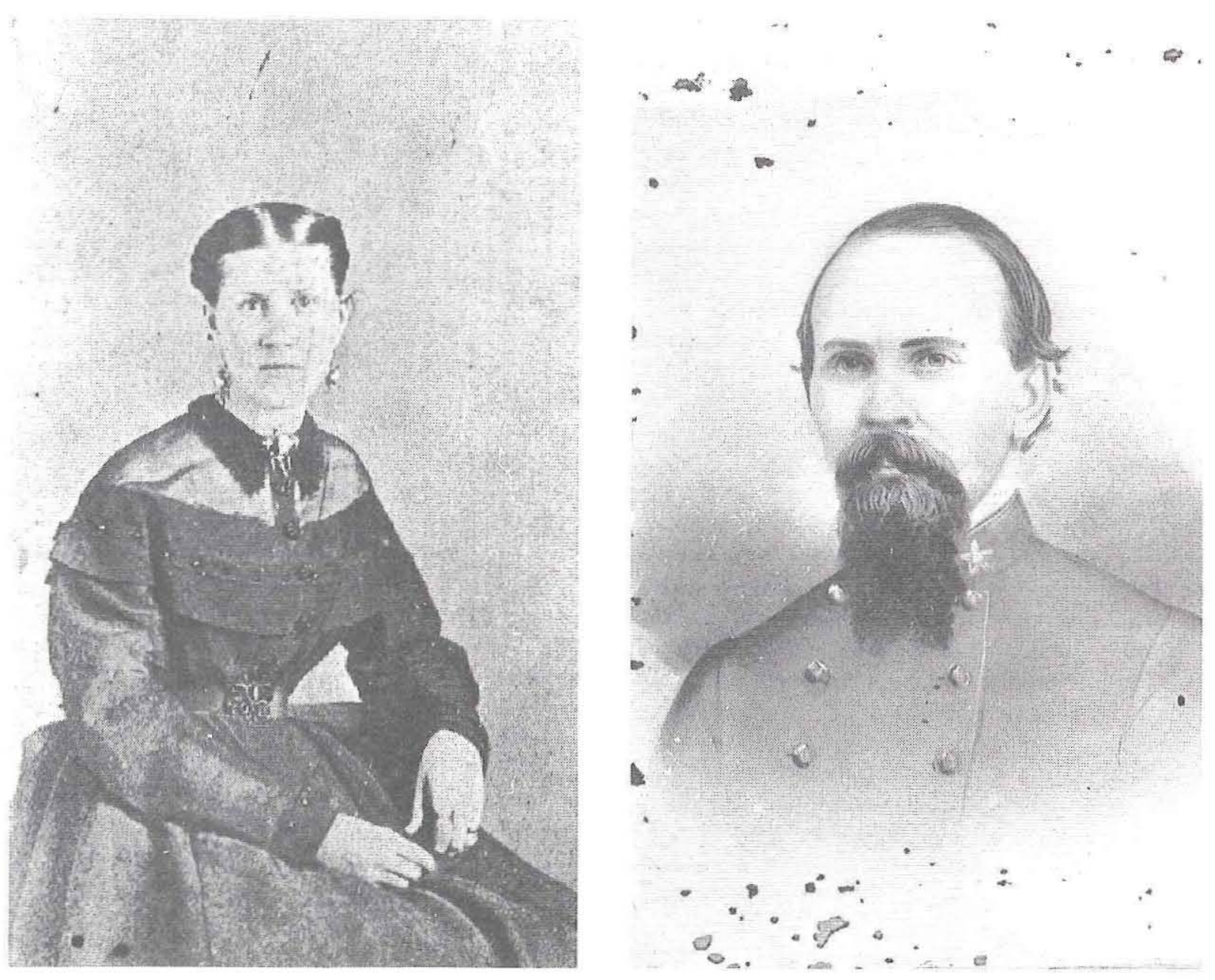

Figure 6. Mary Ann Fanthorp Stone, from a photographic image chalk drawing, and Major William M. Stone, C.S.A., chief quartermaster of the Anderson depot, dates unknown.

the estate included 10 horses, 7 mules, 40 head of cattle, 40 head of sheep, 80 hogs, and 5 yoke of oxen. Miscellaneous farm equipment, a carriage, and $\$ 500$ worth of household and kitchen furniture brought the tangible property total to $\$ 25,686$. Fanthorp also had $\$ 2,100$ in gold on hand (a sizable amount in Reconstruction Texas), \$2,000 worth of stock in the Houston and Texas Central Railway Company, and over $\$ 3,000$ in outstanding personal notes (Grimes County Probate Minutes O:242-243, 265).

During 1868 the Stones endeavored to settle the estate, collect the notes due, and pay any obligations. They rented "The Fanthorp Hotel Bedding fixtures furniture \&c. Stable Lots Garden Orchard \&c to Dr. Heatherly until Jany 1, 1869 for Four Hundred Specie Dollars and Board" for the Stone family. Also included was "as much of the land as he can cultivate fore $[\mathrm{sic}]$ one third of the produce raised thereon." Heatherly, however, did not make a go of the hotel, and Stone reported in October 1868 that the doctor had "sometime since abandoned the place forfeiting his contract without paying any of the rent money. He is perfectly insolvent \& there is no means by which to recover it from him." The hotel was probably out of business during part if not most of 1868 (Grimes County Probate Minutes O:242-243, 265).

When the Stones rendered their final accounting in October 1868, it reflected a reappraisal of the real estate that had been requested by Mary Stone. The reappraisal lowered the real property value to $\$ 14,930$ instead of the previous $\$ 21,436$; much of the decreased valuation was from lowering the value of property that the Fanthorp inn was on. The exhibit also showed that the sheep and two horses had been sold, and the railroad stock had brought $\$ 1,000$ in specie, one-half of its face value. 
Two thousand dollars in outstanding notes were written off as "totally worthless," and almost $\$ 1,300$ in notes were declared "solvent." With this accounting, Mary F. Stone and William M. Stone acknowledged receipt of the estate, and the file was closed (Grimes County Probate Minutes O:263266).

Henry Fanthorp had lived in the inn for over 30 years. During that time, not only had Anderson been born and grown to a thriving community, but also Texas had changed from a frontier to a bustling, enterprising state. Fanthorp's hotel grew into a prosperous enterprise, its heyday corresponding to Anderson's.

\section{AFTERWORD}

Mary Fanthorp Stone had been born at the inn, lived there her entire life, owned it for 33 years, and eventually died there. Only occasional scraps of information or traditions have survived about herthat she helped the Honorable Amelia Murray gather flowers to press and take back to England, that she had a "very fair English education," that she was a "noble Christian woman" and a staunch Episcopalian, and that late in life she was declared non compus mentis [sic] (The Daily Examiner, May 4, 1901, and February 27, 1936; Grimes County Probate Minutes W:318).

At age 21 in April 1865, Miss Fanthorp married Major William Merchison Stone, C.S.A. Stone had been born in Tipton County, Tennessee, in 1834. The date of his arrival in Texas is not known, but he was apparently a resident of Montgomery County when he enlisted in late 1862 at the same time and in the same unit as John Henry Fanthorp. $\mathrm{He}$ began as a private, advanced rapidly, and became a major and chief quartermaster of the Anderson Depot. A family tradition also states that he was on the staff of Major General John G. Walker. After the war, Stone conducted a general merchandising establishment and also farmed the lands his wife inherited (Buffington Family Papers, Fanthorp family genealogical material; Grimes County Marriage Records I:140; Marcus Mallard Papers, unidentified newspaper clipping; Montgomery County Historical Commission n.d.; Fanthorp Family Cemetery, William M. Stone tombstone).

Major and Mrs. Stone had six children, all born at the inn: Mary (born 1865), Annie Virginia (born 1867), Eleanor (born 1869), Julia (born 1870), William Merchison, Jr. (born 1872), and Henry Fanthorp Stone (born 1874). Major Stone died at the age of 40 shortly after the birth of the youngest child (Buffington Family Papers, Fanthorp family genealogical material; U.S. Bureau of the Census 1900).

Not a great deal of information survives regarding the Stones' years at the inn. In 1870 the household consisted of Mary Ann and William Stone and their two infant daughters; George Ehrensfort, a German-born farm laborer, who had apparently been in residence at the inn for at least a decade; six black or mulatto farm laborers and domestic servants; and one Sarah Basset and her daughter Barbara. According to local tradition, a third of the inn was demolished about 1870, and some of the materials were used in the rebuilding of Buffington Hill in 1870. By 1880, however, the widowed Mary Ann Stone, her five children, and Ella Lowery, a black boarder with two young children, were the only listed occupants of the inn (Buffington 1979; U.S. Bureau of the Census 1870, 1880).

Mary Fanthorp Stone had become increasingly eccentric by the mid 1890 s. She developed a strong interest in spiritualism and would attempt to communicate with the dead by tapping on the walls of the inn. Although she became convinced that she and others were about to be poisoned, she was temperate and not dangerous. Finally, in 1896, her children initiated proceedings to have her declared a person of unsound mind. Her son-in-law James Yarborough was made her guardian, and her Grimes County property was mortgaged to set straight her financially confused situation. Mrs. Stone died at the inn in May 1901 at the age of 57, surrounded by her surviving children (The Daily Examiner, May 8, 1901; Grimes County Probate Minutes W:318; Grimes County Deed Record M:403-407).

Four of the Stone children did not play a significant role in the history of the inn. Little Mary Stone died as a child. Her sister Annie Virginia married Grimes County Judge Charles L. Kettler and later H. S. Dodson of Dallas; she died in 1906 at age 39 without surviving issue. William M. Stone, Jr., married Miss Howze Milton, a granddaughter of John Milton, Governor of Florida during the Civil War; the younger Stones initially resided in Anderson but later moved to Marianna, Florida. They reportedly had no children, and the dates of their deaths are not known. Young Henry Fanthorp Stone, described as "the soul of refinement, sensibility, loyalty, and high, noble principles," suffered an accident that affected his nervous system at age 18 , and he died two years later in 1894. The remaining Stone children, Eleanor Stone McDonald and Julia Stone 
Yarborough, were both to succeed to the inn (Blair 1930:127; Obituary of Fannie Huntington Yarborough, July 18, 1914, unidentifed newspaper, Lizzie Scott Neblett. Papers).

Eleanor McDonald, to whom the inn was deeded by her surviving siblings after their mother's death in 1901, attended the Patrick Female Academy in Anderson and was married in 1895 to her lifelong friend and neighbor, J. G. McDonald, Jr., of Anderson (Figure 7). "Gifted with such beautiful traits of nature," Eleanor McDonald was apparently loved by all in Anderson. Cloistered during her pregnancy, she died in 1903 after giving birth to her only child, Mary Eleanor, and was greatly mourned in Anderson. The baby died a few months later in Paris, Texas, and Judge McDonald, following his late wife's wishes, deeded the inn (with little land) in 1904 to her sister Julia, then
Mrs. James Quincy Yarborough of Paris, and the latter's two young daughters. McDonald, however, lived at the inn for many more years (Grimes County Deed Record 51:285, 492; Obituary of Fannie Huntington Yarborough, July 18, 1914, unidentifed newspaper, Lizzie Scott Neblett Papers).

James Green McDonald, Jr., was easily the most controversial owner of the inn. In her Saga of Anderson, Irene Taylor Allen refers to him as "a typical Southern Christian gentleman of the 'old school,'" intensely patriotic, and adored by children (Allen 1957:241-243). In contrast, historian Lawrence Goodwyn suggests that he was a violent racist who succeeded in disenfranchising the black population of Grimes County and may have gone so far as to murder a black Populist leader (Goodwyn 1971).
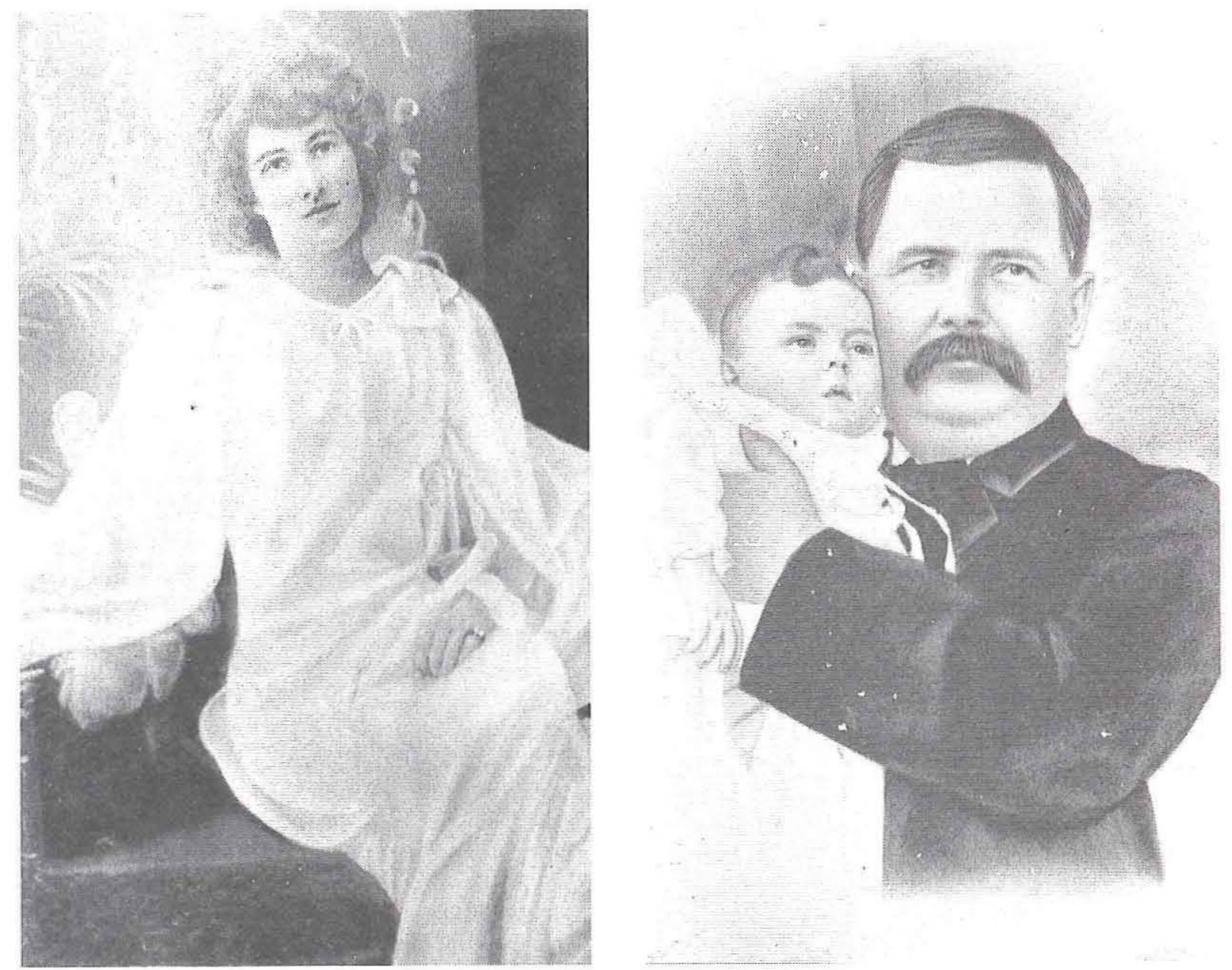

Figure 7. Painting of Eleanor Stone McDonald (date unknown), daughter of Mary Fanthorp and William Stone, died at Fanthorp inn in 1903; and photograph of Judge James G. McDonald, Jr., holding daughter Mary Eleanor McDonald, 1903. 
McDonald was born in Anderson in 1858, a son of James and Julia (Davis) McDonald. The elder McDonald had served in both the Texas State House of Representatives and Senate and as a brigadier general in the Texas State Troops during the Civil War. Young McDonald was educated in Anderson public schools. He worked at various jobs and served as postmaster until admitted to the bar in 1888. His subsequent advancement was rapid. In 1890 he became Grimes County Attorney and in 1892 became County Judge, remaining in office until 1896. While serving as judge, he married Eleanor Stone in 1895 (Allen 1957:242).

It is not known if the McDonalds lived in the inn immediately after their marriage. The 1900 census indicates that they lived in a different residence than her mother, brother, and sister-in-law. Six months after Mary Stone's death in May 1901, however, Eleanor McDonald's siblings chose to deed their interest in the inn to her, indicating a substantial interest in the inn on her part (Grimes County Deed Record 51:281-283).

Grimes County, Texas, at the turn of the century still felt the effects of Reconstruction. The county population had a black majority $(11,664$ out of a population of 21,312), and a black-white Populist coalition continued to elect county officials long after comparable groups in other counties. The most visible members of the coalition were Garrett L. Scott, member of a Grimes County family of some substance and longevity, and Jim Kennard, a black District Clerk elected in 1882. After election defeats in 1896 and 1898, white Grimes County Democrats sought to reorganize. In the spring of 1899, a small group of men met at McDonald's office and organized the Grimes County White Man's Union Association. Public sentiment among Grimes County whites was favorable to the Union, and, after a series of rallies as well as a period of violence, intimidation, and murder, the Union succeeded in ousting the Populist coalition (Blair 1930:197; Goodwyn 1971:1436-1440).

During the upheavals of 1900, Jim Kennard was shot 100 yards from the county courthouse, and Kennard's daughter and others accused Judge McDonald of the slaying. McDonald regretted the shooting and apparently because of public sentiment was not prosecuted. A few months later he was reelected county judge. The day after his election, a shootout on Anderson's main street resulted in the deaths of Sheriff Garrett Scott's brother and others, and the sheriff himself was wounded and died from complications three years later. Nonetheless, the White Man's Union Association prospered through the $1950 \mathrm{~s}$, and, according to tradition, no WMUA nominee was ever defeated. In spite of admonitions found in the Union's bylaws not to harass "inoffensive negroes [sic]," blacks fled the county, and the black population of the county had decreased by at least 30 percent in 1910 (The Daily Examiner, June 5, 1901; Goodwyn 1971:1440, 1442, 1449-1452; McDonald 1979).

Judge McDonald lived to be 79 , undergoing good times and bad (Allen 1957:242; Blair 1930: 126; Johnson 1914:1811-1812; Wharton 1930:76). He was reelected county judge again in 1902 and served in the 30th, 31st, and 36th State Legislatures. $\mathrm{He}$ continued to reside at the inn and was occupied farming the surrounding 855 acres. McDonald maintained a full stable of horses. He was very active in the Masons and seems to have been an unofficial county historian. In 1930 Eric Lee Blair wrote:

Judge J. G. McDonald . . now resides . . . at the old Fanthorp building. Here the writer has enjoyed many an hour's conversation with him, as we sit under the shade of the old oak trees, under which so many interesting events transpired in the early days of Grimes county, while we, now and then, refreshed ourselves from the old Fanthorp well. The writer has found no person so well informed concerning the history of this county, as Judge James Green McDonald. Indeed, he has made it a study and has been considering the preparation of the county history himself. His patience and cooperation is most highly appreciated by the writer.

McDonald also knew tragedy. His wife, father, and only child died within a six-month period in 1903, and he lived alone at the inn for the next 30 years. He became increasingly eccentric and in 1935 was committed to the Austin State Hospital where he died three years later (Blair 1930:124; Grimes County Probate Records, Case 2055; Ratcliff 1979).

The decade following Judge McDonald's departure was a quiet one at the inn. The inn was somewhat dilapidated: the 1936 Historic American Buildings Survey report on file at the Library of Congress described its condition as "bad," and this is born out by photographs of the period. Owners of the inn were absent, and the premises were used mainly for occasional hunting excursions or picnics. The inn was opened occasionally for the Bluebonnet 
Festival or benefits for St. Paul's Episcopal Church in Navasota, but it remained unoccupied (Ratcliff 1979).

Eleanor McDonald's sister Julia had held title to the inn for 40 years before she returned to live there. Born at the inn in 1870, Julia Stone married James Quincy Yarborough, Jr., in 1893. Yarborough's family achieved some prominence in the Grimes County area: the town of Yarboro in the south-central part of the country was named in honor of J. Q. Yarborough, Sr. Julia and James Yarborough had two daughters, Julia (born in 1894) and Alice (born 1896); James Yarborough died in 1898. Ten years later Julia Stone married importer James Perroneau DeSaussure, formerly of Charleston, South Carolina. The DeSaussures traveled far and wide, and lived in a variety of places including the Texas cities of Amarillo, Dallas, and Paris; various New York City suburbs; Honolulu, Hawaii; and Shanghai, China. In spite of years spent in distant parts of the world, Julia DeSaussure retained a fondness and concern for her childhood home and its preservation. In 1940 she sponsored a renovation in which decayed building material was removed and cosmetic improvements made. Five years later, in preparation for the DeSaussures' final return, a more ambitious renovation/restoration was implemented in which plumbing fixtures, a modern kitchen, and other facilities were added (Buffington 1979; Navasota Examiner, September 16, 1965; Obituary of Fannie Huntington Yarborough, July 18, 1914, unidentifed newspaper, Lizzie Scott Neblett Papers; Ratcliff 1979; U.S. Bureau of the
Census 1900).

Mrs. DeSaussure's daughter Julia Yarborough married a Marylander, William Lloyd Garber, and the Garbers lived with the DeSaussures at the inn much of the time. In 1948 the Garber's only child, Alice Lloyd Garber, married Edward Anderson Buffington, scion of a family prominent in Anderson for a century, and they had two daughters, Alison and Barbara. Alice Yarborough, meanwhile, married banker John Noble Ratcliff of Navasota and had two sons, John N. Ratcliff, Jr., and James Quincy Yarborough Ratcliff (of Dallas). As none of Mrs. DeSaussure's siblings produced surviving issue, there are only three known fourth-generation descendants of Henry and Rachel Fanthorp. William Garber died in 1963, Mrs. DeSaussure in 1964, and her widower, the following year. The inn remained the home of Julia Yarborough Garber, who led a quiet existence there until her death in 1976. The inn was inherited by her daughter and son-in-law, who reside nearby in what is known as the old Post Office (Buffington 1979).

The inn attracted a fair amount of attention through the years, although few strangers saw the inside of the landmark. Featured in several books and many newspaper articles relating to early Texas architecture and local history, it received a Texas Centennial Monument in 1936 and was included in the Anderson Historic District in the National Register of Historic Places in 1974. Fanthorp Inn was acquired by the Texas Parks and Wildlife Department in 1977 after almost 150 years in the ownership of Henry Fanthorp and his descendants. 


\section{DESCRIPTION OF THE EXCAVATIONS}

Excavations occurred in 1983, 1984, 1985, 1986, 1987, and 1989. Areas excavated are Rooms 101 and 102 and the yard to the west of the house, the yard north of the house, the dining room porch and adjacent yard including part of Room 106, the area on the south side of the house, and other various areas in the house and yard (Figure 8). Some of these areas were excavated during multiple seasons.

\section{WEST SIDE OF THE INN}

The area under the open west-facing front porch, designated Room 101, was excavated in 1983. Sixteen units of varying size (Units 101-1 through 101-16) defined by porch joists and crosssupports were excavated (Figure 9). The finegrained light grayish brown sediments were homogeneous and loose to moderately compacted. The deposits were approximately $0.5 \mathrm{ft}$ thick and were removed in two levels differentiated by the degree of compaction. Beneath the fill was a thin lens of cultural materials on top of the natural ground surface. No cultural features were found beneath the front porch.

Originally part of the front porch, Room 102 was created when the southern end of the porch was enclosed. Twenty units beneath Room 102 were excavated in 1985 (see Figure 9). The units were determined by the north-south-running floor joists, as were the rest of the porch excavations. The areas between adjacent joists were divided into five $2-\mathrm{ft}$ lengths. Two levels were noted beneath this room, a light-colored sand over a darker sand. A redder soil is mentioned below these two in some units. One night soil standpipe was found in Unit 15. Other pipes were found in this same unit. A drainage channel was found running north-south through Units $1-5$ along the western edge of the room.

In 1985 a 1.5 -ft-wide trench was excavated just under the westernmost edge of the front porch (see Figure 9). Along most of the trench only one level was noted, but in the more southern units three levels were defined. All three of these levels had a sandy matrix, the upper two being tan with more rocks in the second level. The lowest level was more reddish brown. The trench was dug to a depth of between 0.5 and $0.75 \mathrm{ft}$ below the ground surface. Several large support stones were found in these excavations. These stones correspond to where the floor beams of the porch once extended. At least sixteen 3-x-1.5-ft units (labeled PT1-PT16 on Figure 9) were excavated in this trench.

Also in 1985, excavations were conducted west of the front porch for the placement of a French drain (see Figure 9). The 2.5-ft-wide trench ran the full length of the porch and was divided into 3 -ft-long units numbered consecutively from north to south (labeled FD1 through FD13 on Figure 9). This trench ran parallel to the trench mentioned above and therefore also was parallel to the porch.

Two areas in the southwest yard were excavated in 1985. Each excavation was $6 \times 6 \mathrm{ft}$ and divided into four, $3-\mathrm{x}-3-\mathrm{ft}$ units. The first area tested (designated Dry Well I) was at coordinates S302308/E155-161 (see Figure 9). This area was abandoned because very hard sediments were encountered approximately $1 \mathrm{ft}$ below the ground surface. The second area tested (designated Dry Well II) was north of the first at coordinates S290-296/E156162. The levels in these excavations were arbitrary. In the Dry Well I location, a compact brown sandy clay was located below the sod overlying a very compact red sandy clay at around $1 \mathrm{ft}$ below the ground surface. In Dry Well II, the sod layer extended to $0,2 \mathrm{ft}$ below the ground surface. Below the sod to $0.4 \mathrm{ft}$ was dark brown sandy loam with small roots, small pieces of sandstone, and some artifacts. The underlying deposit continued to be made up of this dark brown sandy loam, the distinction being an increase in the number of cut nails and green glass and some mottling with red sandy clay at the bottom of the level which was $0.85 \mathrm{ft}$ below the ground surface. The lowest level reached a depth of $1.1 \mathrm{ft}$ 


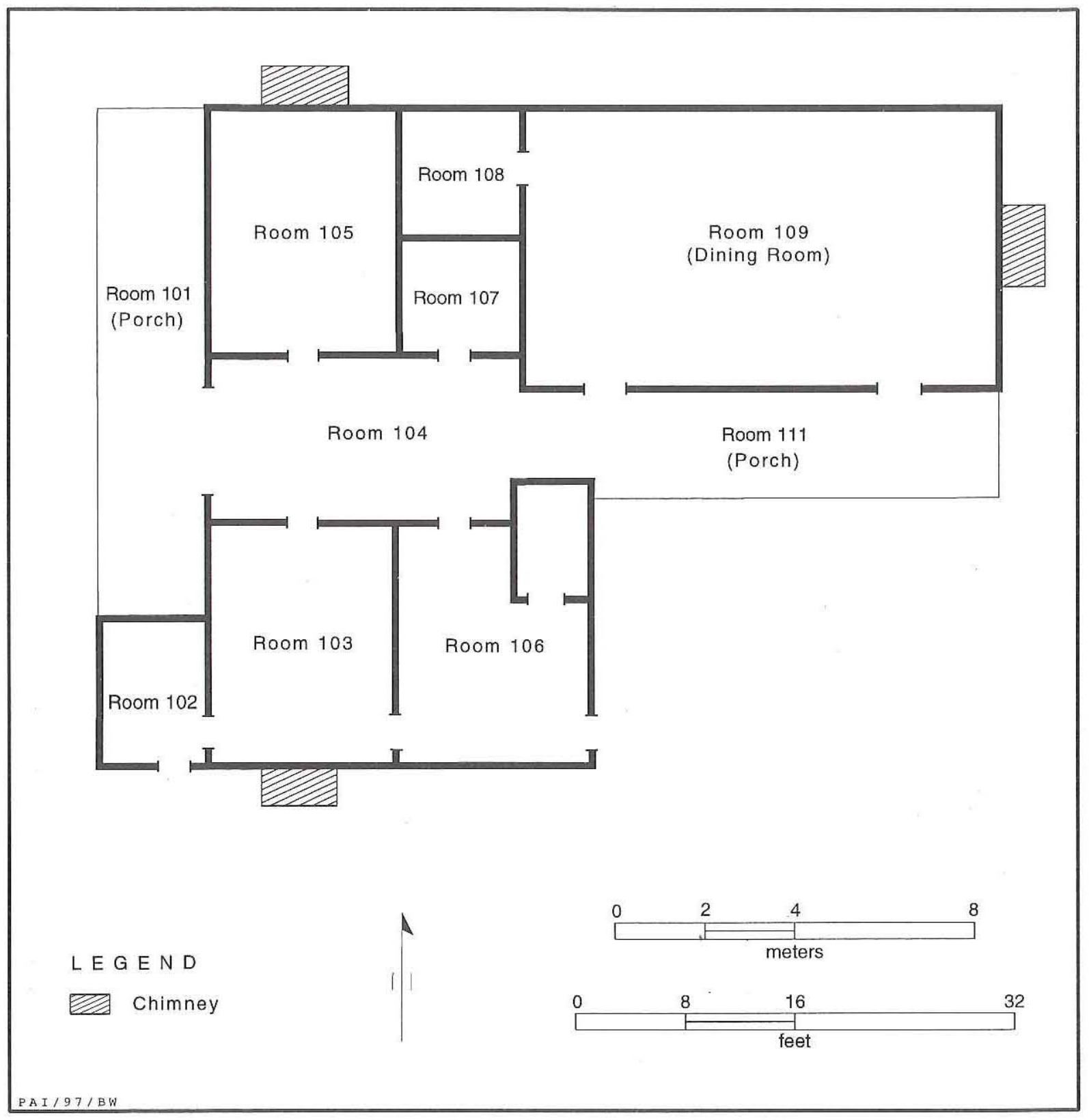

Figure 8. Plan of the first floor of the inn as reconstructed by TPWD.

and became even more mottled with red toward the bottom. One posthole and a corresponding post mold were found in Unit S290-293/E159-162. In line with the southwest corner of Room 102, this posthole was likely part of an old fence line extending from the house.

Also in 1985, a trench was dug from the south end of the French drain to the Dry Well II location (see Figure 9). Eight 2-x-3-ft units were numbered consecutively from north to south. The stratigraphy observed was similar to that in Dry Well II, ex- tending to a depth of approximately $1 \mathrm{ft}$. One unidentified feature was found in Unit 4. It was described as an amorphous area of tan to gray sand with two edges being mostly straight and $0.6 \mathrm{ft}$ on a side.

\section{NORTH SIDE OF THE INN}

In 1984 seven 3 -x-3-ft units were excavated along the north wall of the inn (Figure 10). Unit 216 was beneath the Room 108 window. Units 217 and 


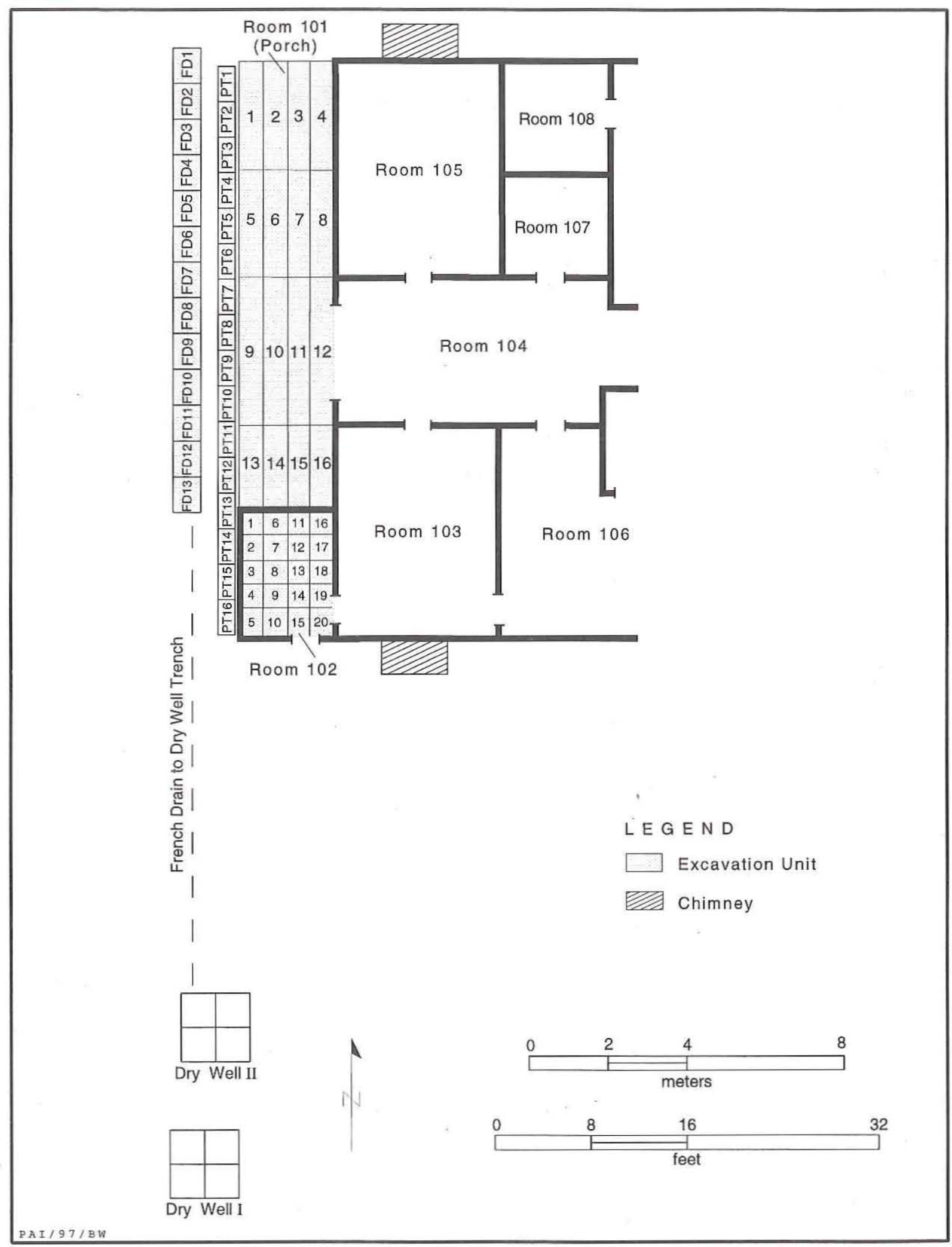

Figure 9. Plan showing excavations on the west side of the inn. 


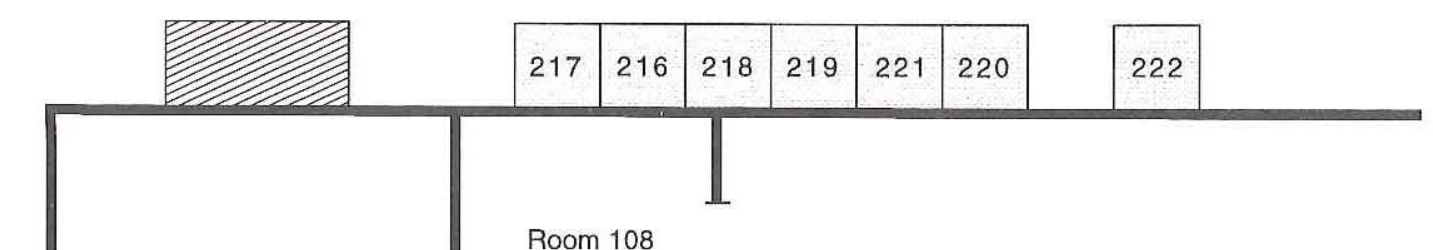

Room 109

(Dining Room)

LEGEN D

Excavation Unit
Chimney
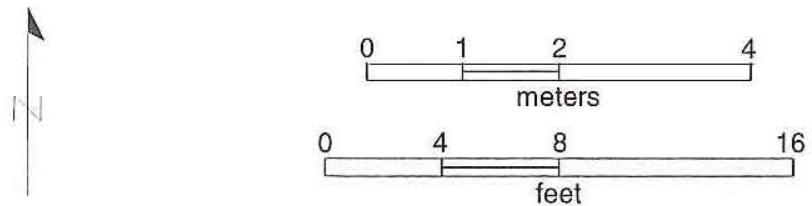

PAI $/ 97 /$ BW

Figure 10. Plan showing excavations on the north side of the inn.

218 were placed to explore a scatter of early materals found in Unit 216. Units 219-221 were excavated next to the cellar beneath Room 109 (the dining room). Unit 222 was the easternmost unit.

All units exhibited similar sediments, which were generally removed as three levels. The uppermost deposits consisted of loose organic materials such as roots. The deposits underlying the uppermost organic layer in Units 217-221 consisted of about $0.5 \mathrm{ft}$ of rubble, although the original surface was not always distinct. Bedrock consisting of tabular fragments overlying solid rock was encountered between 0.8 and $0.9 \mathrm{ft}$ below the surface. A buried water pipe paralleling the wall extended the full length of the excavations, and Units 216,218 , and 219 contained a sewer pipe and additional water pipes. Sandstone rubble concentrations were found in Units 216 and 217 at about $0.5 \mathrm{ft}$ below the surface. The rubble was most frequent in the northern half of each unit, away from the wall. Scattered rubble also occurred in other units. The rubble could be associated with the chimney on the north wall of the inn or the disruption caused by the placement of water and wastewater lines.

Two features were found in the units next to the cellar. One was a trench dug to allow foundation repairs, probably during renovation in the 1940s. The second was the edge of the original cellar excavation, which was visible upon removal of the fill from the foundation repair trench. The excavation for the cellar extended into the units only slightly, with the stone cellar wall also serving as the foundation for this part of the building. No external entryway into the cellar was found in these units, and the exposed foundation of the dining room was continuous and original.

\section{DINING ROOM PORCH, ROOM 106, AND ADJACENT YARD}

The yard to the south of the dining room, the dining 
room porch (also known as Room 111), and Room 106 are all spatially related to Cistern 1 and were affected by its excavation (Figure 11). All of these areas contain what has been termed here as "cistern spoil" in their sediments. This deposit consists of the bedrock deposits that were excavated from the cistern and could be recognized by the white cast created by the presence of sandstone. The cistern spoil could in most cases also be mixed with cellar spoil. The yard south of the dining room was investigated in 1984, and the dining room porch was dug in 1983 and 1984. Room 106 was investigated primarily in 1983 and 1984 with minor investigations in 1985, 1986, and 1987.

The dining room porch was divided into 16 units, each approximately $4-\mathrm{x}-4-\mathrm{ft}$ in size. The deposits beneath this porch were relatively intact. Units 111-12 and 111-16 and possibly Unit 111-15 adjacent to the west entrance of the dogrun (Room $104)^{7}$ and Unit 111-8 were dug in 1983 , as were Units 111-1, 111-2, 111-3, 111-4, and 111-5 along the wall skirt at the east end of the porch. Areas along the porch perimeter investigated in 1984 included the north halves of Units 111-6 and 111-7 and the south halves of Units 111-9, 111-10, and 111-11. Units 111-13 and 111-14 between Units 111-8 and 111-15 were not excavated.

Just south and east of the porch, eight 3-x-3-ft units were excavated in 1984 to investigate the location of the original porch step and the relationships between the support piers, the wall skirt, and bedrock (see Figure 11). Units 210 and 215 were located at the existing porch step; Units 194, 202, 204, and 214 were east of Unit 215 along the south side of the porch; and Units 225 and 226 were along the eastern end of the porch. Eight 3-x-3-ft units were excavated farther south. Units 205, 206, 207, and 208 were near the kitchen; Unit 211 was west of these units in the area of a flagstone walk that connected the porch and garage; and Units 197, 198, and 209 were adjacent to units bordering the porch on the south.

The nearly empty cistern located outside the east wall of Room 106 was designated Cistern 1. Six 3-x-3-ft units were excavated next to the feature to investigate the adjacent cistern spoil in 1984 . Units 212 and 228 were contiguous and were east of

${ }^{7}$ Room 104 is the dogrun that separated the two original log pens of the house, as represented by groundfloor Room 105 on the north; Room 104 subsequently was extended eastward when the original back porch was enclosed and the dining ell was added, and it became an enclosed room with the addition of doors onto the front porch (Room 101) and the dining room porch (Room 111). the cistern. Contiguous Units 213, 227, 229, and 230 sampled the area just north of the cistern, south of the porch, and east of Room 106 (see Figure 11).

Room 106 is the enclosed back porch, which was extended eastward by ca. $5 \mathrm{ft}$ sometime after it was originally enclosed. This later addition east of the original enclosed portion is the area investigated archeologically (with the exception of Unit 106-1) and is also the area that presently contains bathroom facilities put in during the 1940 s renovation. Investigations in 1983 were conducted to recover information on the date of this addition and included Units 106-1 and 106-2 located, respectively, inside and outside the original exterior wall (see Figure 11). Further work was done in 1984 in the southeast corner of the room outside the original porch. Units $106-3,106-4$, and 106-5 were adjacent to the original exterior wall and were separated by a balk containing a sewer pipe from Units 106-6, 106-7, and 106-8 on the west side of the current addition wall. Unit 106-9 was placed in the northern part of the Room 106 addition.

Throughout the entire area encompassed by the porch, Room 106, and the yard area in between, the deposits are similar although they vary from unit to unit. Cistern spoil occurred in a triangular area defined by the wall of the dining room and the original inn back porch (now part of Room 106), and was concentrated northwest of the cistern where the deposits were thickest (they were over $2 \mathrm{ft}$ thick in Unit 230); it is estimated that ca. $300 \mathrm{ft}^{3}$ of cistern spoil was present. The cistern spoil deposit was not homogeneous, with much of the variation reflecting the heterogeneous nature of bedrock consisting of interbedded consolidated and loose sands. Also present were lenses of nonbedrock sediment and possible construction debris. Mounded spoil was present around the neck of the cistern and decreased in thickness to the east. At its edges, the spoil deposit was thin and consisted of washed sands or spoil mixed with other deposits. Under the western end of the porch just east of the original exterior wall of the inn, the spoil overlies other kinds of cultural deposits such as charcoal and bones in Unit 111-16. Deposits between the cistern spoil and the level interpreted as the original ground surface indicate that the cistern was built some time after the original occupation of the site in 1834, although below the central part of the porch, mounded spoil directly overlay the original ground surface. Those deposits under the porch and those under Room 106 are less compacted and less disturbed than those exposed areas in the yard.

Under the porch, three deposits were noted 


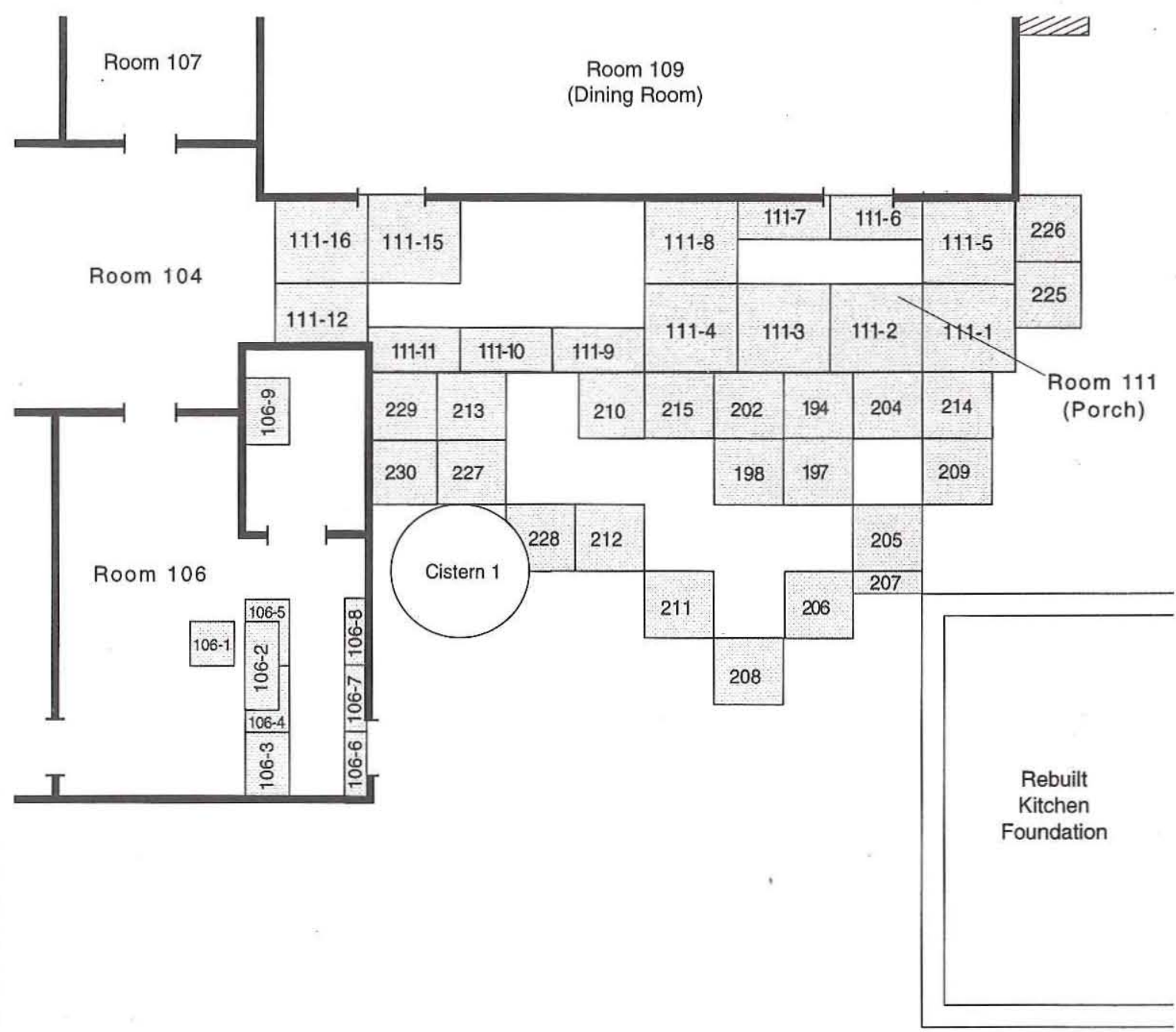

LEGEND

Excavation Unit

Chimney
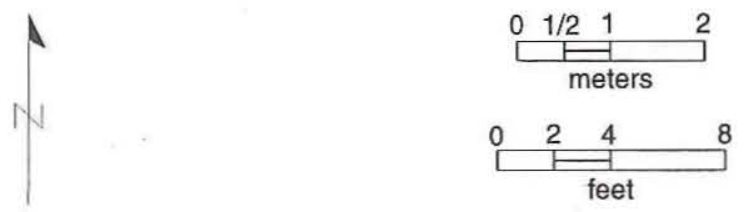

PAI $/ 97 /$ BW

Figure 11. Plan showing excavations beneath the dining room porch (Room 111) and Room 106 and in the adjacent yard. 
above the thin (less than $1 \mathrm{ft}$ thick) cistern (or perhaps cellar) spoil: loose surface sediments, the more-consolidated sediments beneath, and the compacted sediments on top of the cistern spoil. In the yard to the south of the porch, the surface sediments consisted of as much as $0.7 \mathrm{ft}$ of sediment containing composition shingle minerals overlying a sandstone rubble scatter. Where cistern spoil was present, this was directly below the rubble layer. In Units 194 and 204, a board trough feature under the rubble layer was underlain by an ashy deposit overlying the original ground surface. Tabular fragments overlying solid parent material constitute bedrock. Throughout the yard, deposits tended to be between 0.6 and $1.6 \mathrm{ft}$ thick, with the thinner deposits being closest to the porch.

Beneath Room 106, the uppermost level tended to be a loose, sandy, unconsolidated layer with little or no organics. The cistern spoil was present in Units 106-2, 106-3, 106-4, 106-5, 106-6, 106-7, and 106-8, and like the other units in the area, a transitional layer between this and the original ground surface was noted. Ash lenses were found in these deposits also but were mixed and discontinuous across the units, as the cistern spoil tended to be. Unit 106-1 inside the original porch had only a single deposit consisting of sediments that had accumulated under the floor; no cistern spoil was present. The excavations in Unit 106-9 only removed the upper level of unconsolidated sediments that had been deposited through the floorboards.

Features encountered under the porch included piers of dry-laid sandstone rocks supporting the porch joists and support piers adjacent to the south wall of the dining room. These piers sat on or were slightly embedded into the original ground surface, contained old lime and sand mortar, and predated the deposition of cistern spoil. Also encountered was a continuous stone skirt under the porch which was made using Portland cement, indicating morerecent construction than the porch or perhaps repointing of the original skirt. The piers and wall skirts at the north end of Room 106 sit on cistern spoil, indicating later construction than the cistern; the stones have been repointed with Portland cement.

Noted in Units 111-6 and 111-7 was an irregular shallow trench of unknown origin next to a slight ridge. The original ground surface under the porch had been compacted, apparently by foot traffic. South of the porch was a 1-inch water pipe which extended under the porch and ran eastnortheast across Unit 226 at $0.3 \mathrm{ft}$ below the sur- face. The porch steps in Units 210 and 215 were made of Portland cement and were likely constructed in the twentieth century; there was no evidence of an earlier step. A flagstone walkway on the surface in Units 215 and 211 was also a twentiethcentury feature and connected the porch and the detached garage to the south. Unit 206 contained a concentration of cement gravel, apparently representing an area where cement was mixed recently. Unit 209 contained two possible postholes which lined up with a twentieth-century fence which extended south from the east end of the dining room.

Units 194, 202, 204, and 214 contained a feature made of cedar boards paralleling the porch. It consisted of a V-shaped trough about $0.2 \mathrm{ft}$ in depth formed by two boards placed in an excavated trench. The trough was $0.6 \mathrm{ft}$ wide at the top, but did not meet at the bottom, leaving a gap of $0.1 \mathrm{ft}$ at the base of the $\mathrm{V}$ shape. The trough was just over $6 \mathrm{ft}$ long and sloped down $0.1 \mathrm{ft}$ from west to east. Because of decay, additional details could not be determined.

The units south of the porch contained sandstone rubble apparently representing a general rock scatter centered in the open yard. Since this rubble overlay cistern spoil, it postdated the construction of the cistern. The rubble may have resulted from the demolition of the detached kitchen and renovation of the inn in the 1940s, although the occurrence of rubble below a buried water pipe outside the south wall of the inn suggests that the rubble may have been present prior to the renovation (or maybe it was deposited early in the renovation). Sandstone rubble was found in most units near Cistern 1. Some of the rocks could be debris associated with construction of the cistern, or they may be associated with the general rock scatter present in the southern yard.

At the time the property was acquired by the Texas Parks and Wildlife Department, a porch shed with roof supports, lattice walls, and a concrete slab foundation covered Cistern 1. This porch shed was later demolished for the inn restoration. The perimeter foundation trench, filled with rebar and scrap lumber, was exposed in Unit 212. Units 229 and 210 contained square postholes with diameters of $0.5 \mathrm{ft}$ lined with vertical sandstone rocks; they extended about $0.5 \mathrm{ft}$ into the cistern spoil and apparently held support posts for a roof that predated the porch shed and was extant in the 1920s. The cistern itself was about $12 \mathrm{ft}$ deep, had a slightly basin shaped base approximately $11 \mathrm{ft}$ in diameter, had a neck diameter of $6.3 \mathrm{ft}$, and was 
lined with $1.5-2.0 \mathrm{ft}$ of rocks covered with lime plaster.

Room 106 features consisted of aboveground sewer pipes and water lines associated with recent bathroom facilities, the foundation of the outside wall, and the original back porch foundation. The outside wall foundation varied in that the southern half had lime and sand mortar while the northern half had been repointed with Portland cement. The piers in the original porch foundation also have lime and sand mortar, as does the skirting between the piers. Based on the fact that cistern spoil abuts the skirting, it must predate the excavation of the cistern.

\section{SOUTH SIDE OF THE INN}

Four tests were excavated along the south wall of the inn during 1984 (Figure 12). Test Unit 1 was next to the south side of the chimney; Test Units 2 and 3 were adjacent to the foundation skirting west of the chimney; and Test Unit 4 was next to the skirting near the east end of the wall. Later in 1984, 3-x-3-ft Unit 223 was placed next to Test Unit 4 outside Room 106, and 3-x-3-ft Unit 224 was excavated near the exterior door from Room 102.

These units contained similar sediments, with loose or disturbed surface materials overlying more-

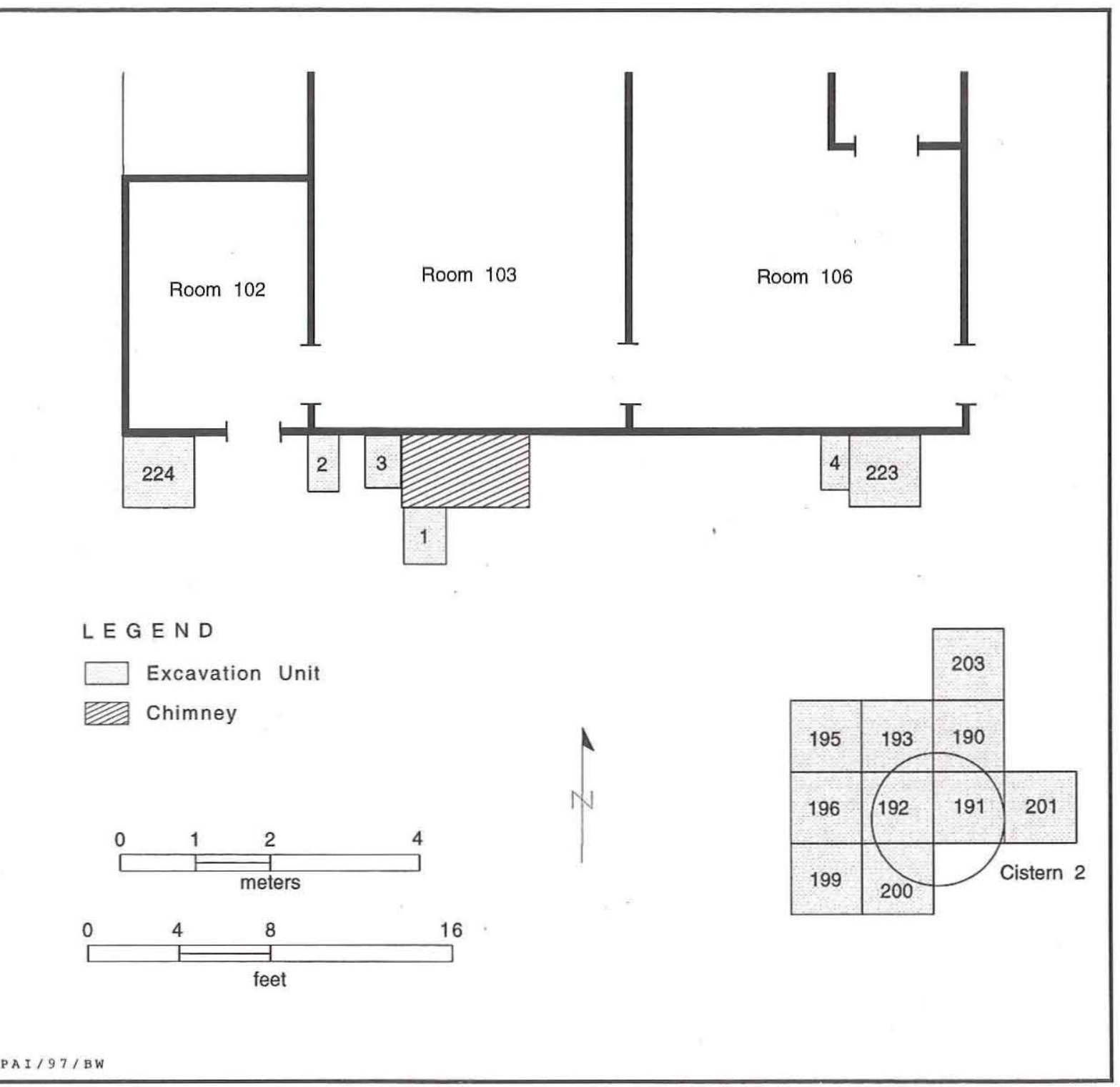

Figure 12. Plan showing excavations on the south side of the inn. 
intact compact deposits above construction rubble atop the original ground surface. The original ground surface was shallower at the eastern end of the wall than at the western end. Bedrock was encountered at depths ranging from 2.4 to $3.0 \mathrm{ft}$.

The excavations in Unit 223 exposed three 1inch water lines. Two ran southward through the unit after exiting Room 106 above ground, and the third ran east-west beneath the first two. A water pipe also was found in Test Unit 4. Unit 224 contained other recent features, including flagstones on the surface in the western half of the unit that may be a path or step from Room 102. In the same unit was a circular posthole, which may have been associated with a gate adjacent to the unit and a wooden fence that at one time enclosed the yard south and east of the inn. Sandstone rubble was found in all excavations except Test Unit 2. In Unit 224 , apparent construction rubble was buried less than an inch below the surface. In Test Unit 4, scattered rubble was found below the buried water line. The eastern half of Unit 223 contained a dense layer of rocks perhaps representing a pavement or walkway at about the same depth. As observed in Test Unit 1, the buried footing for the south-wall chimney sits on bedrock ca. $2.4 \mathrm{ft}$ below the surface and extends $0.5 \mathrm{ft}$ out from the base of the chimney. All of the observed south-wall foundation piers were on or near the original ground surface.

Cistern 2, identified during testing in 1978, was approximately $14 \mathrm{ft}$ south of the southeast corner of the inn (see Figure 12). It was investigated in 1984 with ten $3-\mathrm{x}-3-\mathrm{ft}$ units arranged in an irregularly shaped block. The first four units (Units 190-193) were in the area of a 1978 test and were intended to help define the mouth of the cistern. These units exposed horizontal cedar logs surrounding a collapsed area. Units $195,196,199$, and 200 were excavated west and south of the initial units to further explore the log cistern cover and the cistern opening. Units 201 and 203 were placed east and north of the initial units in an effort to identify a reported entryway created for reuse of the cistern as a storage facility. Units 192 and 200 were dug to provide a deep test of the deposits.

The lowermost fill of the cistern (under water at the time of excavation) consisted of fine-grained, light gray sediments containing some sandstone. Above this was a 6-ft-thick deposit interpreted as a single episode of trash disposal. This deposit consisted of about 50 percent construction debris, including sandstone rubble, and highly varied artifacts within washed-in matrix. Rubble and whole artifacts were more frequent around the edges of the feature than in the center. Construction rubble including sandstone and plaster fragments also was found in the surface sediments in and around the depression at the mouth of the cistern. This rubble postdates filling of the feature and may reflect efforts to level the ground surface.

Bell-shaped Cistern 2 was $12 \mathrm{ft}$ deep and about $12 \mathrm{ft}$ in maximum diameter, with a neck diameter of approximately $6 \mathrm{ft}$ and a slightly basin shaped bottom. It was dug into sandstone bedrock, and the interior was plastered with lime mortar. The neck and lip extended above bedrock and were plastered as well, with the original plaster having been replaced by Portland cement at some point. Debris from the later plaster was seen in some of the excavations. According to an informant report, Cistern 2 functioned as a cellar during the early part of the twentieth century, and the cedar logs covering the mouth, with mottled yellow and gray clay plaster on the top and bottom, may relate to this period of use. At the time of the 1984 excavations, the western half of the roof was relatively intact. The entrance to the cellar and much of the eastern half of the cistern apparently were destroyed by excavations for a septic tank and sewer pipe. Part of the cement cover of the septic tank was exposed in Unit 201, and Unit 203 had been disturbed by the placement of the sewer pipe and a water line.

\section{CELLAR WALL}

The north wall of the cellar beneath the dining room was removed during inn reconstruction. When this was done, substantial deposits were noted in the cellar, and these were tested archeologically in 1985. Seven units were laid out along the line of the north wall, numbered consecutively from east to west. Each unit was $1 \mathrm{ft}$ north-south by $2 \mathrm{ft}$ east-west. Only notes for Units 5 and 6 are available, so it is not clear how many units were excavated, and up to 13 levels were dug. Mixed deposits with construction materials made up most of these levels. Portland cement, mortar, wood, and iron fragments were noted in the fill. A hole was found in the western end of Unit 6 and encroaching upon Unit 7. This hole contained mortar or Portland cement fragments as well as iron fragments, but additional details on this feature and its function are not known.

\section{CHIMNEYS}

The north, south, and east chimneys (see Figure 8) were excavated in preparation for new footings to be poured during the 1985 season. The 
chimneys had all been dismantled prior to the archeological investigations. As expected, each chimney had an upper level containing ash and charcoal, and a lower level was described in the east chimney as primarily ash. The bottom of each hearth appears to have consisted of sandstone rocks, and in the south chimney there is some evidence of mortar having been used to hold the rocks in place. Below the sandstone rocks was a core of large rocks and rubble. The east chimney, aside from the fireplace itself, contained a gas pipe which cut through the ash deposit. Also found in this chimney footing was an iron water pipe.

\section{PIERS}

Stabilization of the dining room and dogtrot floors was required during the restoration work in 1985. This included jacking up seven of the floor joists and building new piers under them. Jack platforms (about $1 \times 1.5 \mathrm{ft}$ in size) were cleared at the south of the seven existing piers, while new pier holes (minimum size of $1 \times 1.5 \mathrm{ft}$ ) were excavated north of these existing piers. The platforms and the pier holes were excavated archeologically to collect any impacted archeological materials. Piers 2, 4, 7, 10, 13, 14 , and 15 were excavated (Figure 13). The location for pier 13 is not known, and the plottings of piers 14 and 15 on Figure 13 are only approximate. Notes for pier holes 2 and 4 indicate that the old piers were removed during the excavation.

Within the pier 10 excavation, four strata were identified. The first two were ca. $0.5 \mathrm{ft}$ thick and were described as being identical except for a higher concentration of artifacts in the lower level. The third stratum was ca. $0.3 \mathrm{ft}$ thick and was similar to the first two with some tan sand present. The lowermost deposit was described as being similar to the overlying materials with some bedrock matrix added. Within other pier units, two to four levels, some arbitrary, were dug under the floorboards. The sediments were similar to those found under the porches with brown sands over reddish sand.

One depression containing broken sandstone or concrete was found in the northeast corner of the pier 7 unit beneath the dining room. A drain from the roof directs water toward this depression, suggesting its function as a drain. Also found in this unit was the base of a 4-x-4-inch post set in to align with the wall.

\section{ATTIC}

Work in the attic was performed during 1985. The attic was divided into sections using the floor joists. Each joist was numbered starting at the west end of the attic and moving east. The areas investigated were defined by the joists, meaning that long sections running north-south between the joists were used as units of study. Architectural details were recorded, deposits from construction activities were examined, and artifacts were collected.

\section{UTILITY TRENCHES}

Several utility lines were excavated on the Fanthorp property during the 1986 and 1987 seasons (Figure 14). Described below are those that the archeologists monitored. During the 1986 season, a trench was excavated along the S246.5-248 line. The trench started at E211 and extended to E361. The trench was divided into 3 -ft-long units, most of which were excavated. This trench was used to house a drainage pipe that ran from the eaves of the house through Cistern 1. Another trench, excavated along S234-235 in 1987, was $1 \mathrm{ft}$ wide and started at E230 and extended to E262. This trench was also divided into 3-ft-long units (except for the easternmost unit, which was $2 \mathrm{ft}$ long), and all units were excavated. This trench was excavated for the installation of an electrical line to a floodlight behind the house.

During the 1987 season, archeological monitoring was necessary during the excavations to install two septic tanks and three drain fields and to excavate a trench from the new barn to one of the septic tanks. The area removed for each septic tank was approximately 10 to $12 \mathrm{ft}^{2}$. Also monitored was a ditch dug along the east side of the road for the installation of four large pipes. What became known as the Sewer Line Utilities Trench was excavated from the southeast corner of Room 106 and extended south and west to one of the septic tanks. The Barn Utilities Test Trench was also excavated; it ran from the southeast corner of the house west toward the barn. It extended at an angle out from the house corner and then curved to head due west just east of the gravel walkway. At least five other units in the area of the front gravel walkway, designated as F.G.W. 1, 3, 5, 9, and 25, were excavated.

\section{FENCE POST TESTS}

Notes for a very short season in 1989 indicate that three fence post tests were excavated (see Figure 14). The areas examined were $41.5 \times 18.5$ inches, 37 x 21 inches, and $36 \times 18$ inches. In two of these areas, recently drilled holes of 9- and 9.5-inch diameters were found, and in the third, an old wooden fence post was found. 


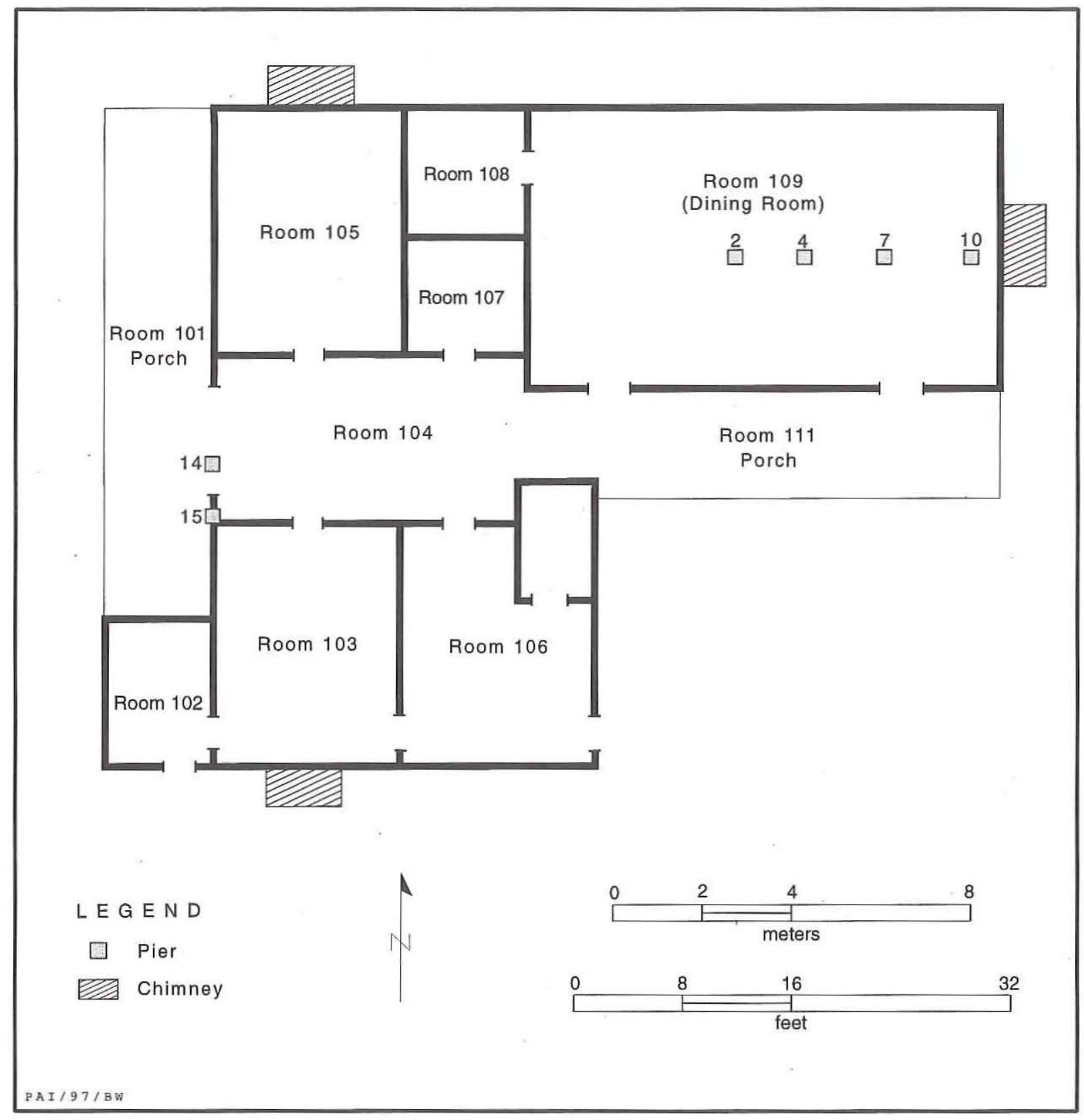

Figure 13. Plan showing the excavated piers. 


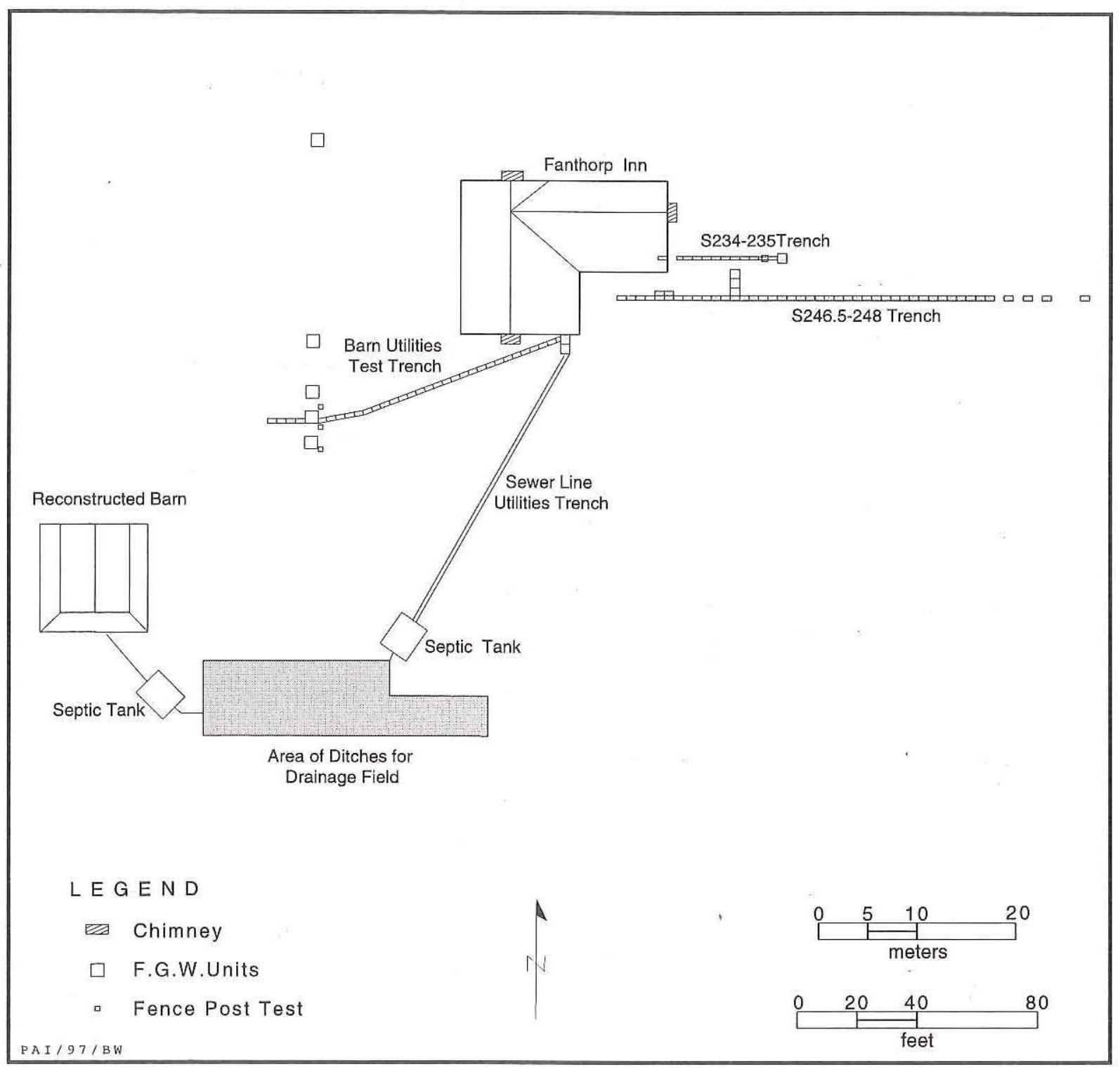

Figure 14. Plan showing utility trenches dug in 1986 and 1987 and fence post tests dug in 1989. 


\section{THE ARTIFACTS}

\section{ARTIFACT ANALYSIS OVERVIEW}

The initial inventory of the artifacts recovered from the site during 1983-1989 was performed during the 1980 s, with the grand total calculated at 108,835 specimens. In 1994 and 1995, the collection was inventoried by TPWD staff for a second time in part to prepare for transmitting the materials to Prewitt and Associates for analysis. The artifacts from each lot bag were recounted and a second set of catalog sheets identifying the artifacts using the TPWD classification scheme was filled out. This second inventory is the one used here to summarize the collection. As noted in Chapter 2, this was accomplished by completing the artifact coding based on the identifications made by TPWD staff and recorded on the catalog sheets and then entering the data into a spreadsheet so that totals could be calculated. According to this second inventory, the collection contains 119,561 specimens. Because PAI did not re-examine most of the materials to confirm that they had been correctly identified and counted, it is difficult to attest to the accuracy of the inventory or to explain the discrepancy in total count between the two. It is heartening, however, that the two totals are not more divergent given the amount of time that elapsed between the excavations and the second inventory and the fact that different people were involved in the various inventories. Based on observations by PAI staff during completion of the coding, it is likely that the inventory is most accurate for the general artifact group totals, with accuracy decreasing for the more specific artifact class and type totals.

The artifact counts given in this chapter come from two sources. The summaries provided in Table 1 , where the overall collection is characterized, are derived from the second TPWD inventory. Later in the chapter where selected categories and items are described in more detail, artifacts were actually counted by PAI personnel during the analysis. In some cases, the counts presented in the detailed descriptions are not in agreement with those given in the summary tables due to differences in how artifacts were classified. Nonetheless, the TPWD inventory counts are used in the summary tables to maintain internal consistency.

The total artifact count for the site is 119,561 (Table 1). As at most archeological sites, the largest group, totaling 45,549 artifacts, or 38 percent of the total collection, is the Unknown group. This includes faunal and botanical remains and those artifacts that cannot be identified to use, including unidentified metal, glass (although most of the unidentified glass is included in the Domestic group under Culinary glass), ceramics, paper, leather, wood, plastic, and rubber. The unknown group also includes any prehistoric artifacts collected at the site, whether identified or not, and the quartz crystals and other items discussed in Chapter 6.

The next largest group of artifacts is Architecture with 37,463 artifacts, or 31 percent of the collection. As previously mentioned, these artifacts are not described in this report because the architecture at the site is well understood and the building has already been restored. Nails and flat glass make up 90 percent of this group.

The Domestic group, from which many of the analyzed artifacts in this chapter were chosen, consists of 33,543 artifacts, or 28 percent of the collection. The largest portion of the Domestic group is composed of glass (including unidentified glass sherds and most bottle types), ceramic sherds, and lamp chimney glass. These three types are represented in the following analysis section of this report along with tableware glass, pressed glass, and flaked or knapped glass. Other large categories within this group are tin cans, home education supplies such as slate boards and pencils, and straight pins.

Personal is the next largest group, with a significantly smaller number than the previously mentioned ones. Only 1,848 personal artifacts, or 2 percent of the collection, were recovered. The Personal group includes those artifacts that relate to an individual person's activities, such as clothing, jewelry, medical 
Table 1. Inventory of Materials Recovered, 1983-1989

\begin{tabular}{|c|c|}
\hline PERSONA & \\
\hline Clothing & \\
\hline Fasteners & 1 \\
\hline zipper & 5 \\
\hline suspender loop & 29 \\
\hline snap/rivet & 22 \\
\hline grommet & 6 \\
\hline stud & 13 \\
\hline buckle & 13 \\
\hline collar and cuff studs & 14 \\
\hline misc. & \\
\hline Buttons & \\
\hline ferrous & 5 \\
\hline cuprous & 15 \\
\hline white metal & 1 \\
\hline china & 67 \\
\hline glass & 17 \\
\hline bone & 42 \\
\hline shell & 125 \\
\hline plastic & 5 \\
\hline misc. & 341 \\
\hline Fabric & 19 \\
\hline Undergarments & \\
\hline fabric & 3 \\
\hline hardware & 4 \\
\hline Accessories & \\
\hline purse & 1 \\
\hline belt & 2 \\
\hline misc. & 2 \\
\hline Notions & \\
\hline safety pin & 29 \\
\hline hook and eye & 16 \\
\hline hook only & 26 \\
\hline eye only & 20 \\
\hline misc. & 1 \\
\hline Footwear & \\
\hline Grommet & 54 \\
\hline Shoe Parts & \\
\hline upper & 2 \\
\hline sole & 6 \\
\hline heel & 4 \\
\hline laces & 19 \\
\hline misc. & 18 \\
\hline Adornment & \\
\hline Jewelry & \\
\hline ring & 2 \\
\hline misc. & 34 \\
\hline Beads & \\
\hline glass & 143 \\
\hline misc. & 121 \\
\hline Misc. & 16 \\
\hline Body Ritual & \\
\hline Teeth & \\
\hline toothbrush & 6 \\
\hline dentures/partials & 1 \\
\hline
\end{tabular}

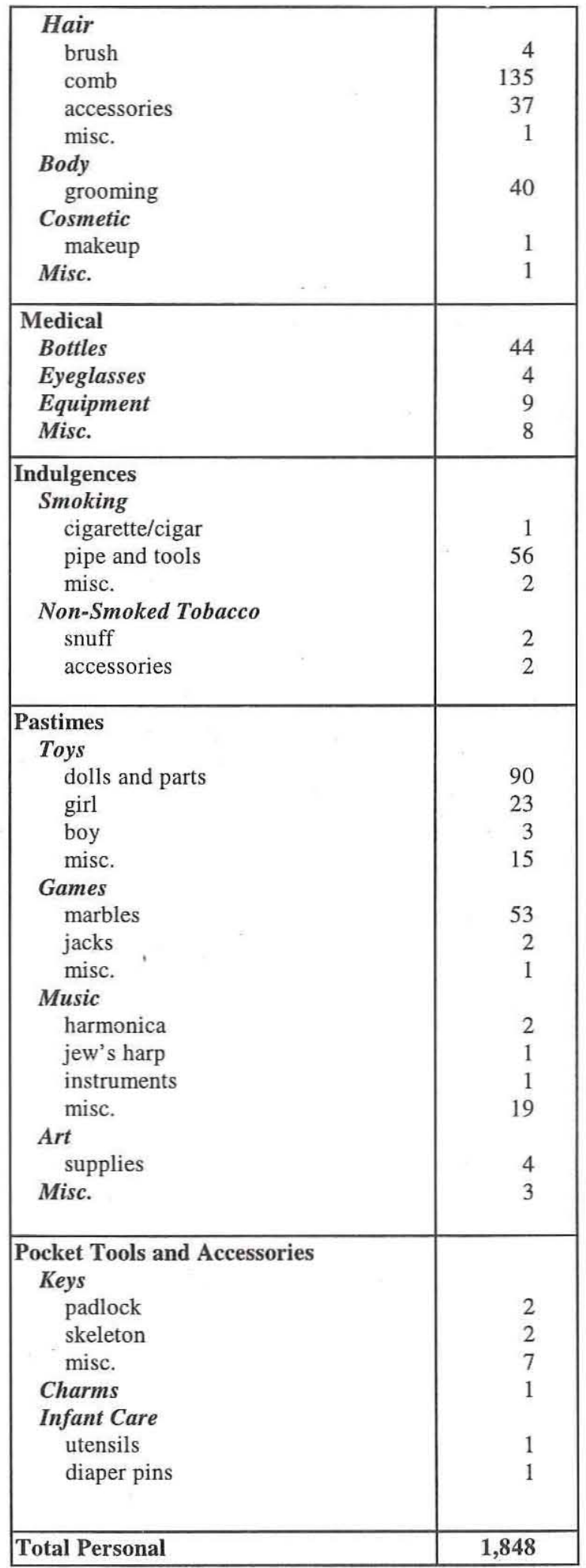




\begin{tabular}{|c|c|}
\hline \multicolumn{2}{|c|}{ DOMESTIC } \\
\hline \multicolumn{2}{|l|}{ Furnishings } \\
\hline \multicolumn{2}{|l|}{ Furniture } \\
\hline hardware & 6 \\
\hline object & 1 \\
\hline misc. & 5 \\
\hline \multicolumn{2}{|l|}{ Drapery/Window Coverings } \\
\hline cloth & 2 \\
\hline hardware & 10 \\
\hline \multicolumn{2}{|l|}{ Decorative } \\
\hline knickknacks & 1 \\
\hline floral arrangements & 1 \\
\hline misc. & 4 \\
\hline \multicolumn{2}{|l|}{ Wall/Ceiling Coverings } \\
\hline wallpaper & 1 \\
\hline misc. & 6 \\
\hline \multicolumn{2}{|l|}{ Housewares and Appliances } \\
\hline \multicolumn{2}{|l|}{ Culinary } \\
\hline ceramic & 178 \\
\hline glass & 19,856 \\
\hline utensils & 11 \\
\hline cookware & 98 \\
\hline tin cans, etc. & 1,134 \\
\hline stove & 19 \\
\hline misc. & 4 \\
\hline \multicolumn{2}{|l|}{ Gustatory } \\
\hline ceramic & 6,487 \\
\hline glass & 643 \\
\hline utensils & 20 \\
\hline serving dishes & 3 \\
\hline condiments & 2 \\
\hline drinks & 47 \\
\hline misc. & 2 \\
\hline \multicolumn{2}{|l|}{ Portable Illumination } \\
\hline lamp or parts, misc. & 9 \\
\hline chimney glass & 3,214 \\
\hline lamp parts & 20 \\
\hline matches & 77 \\
\hline batteries & 1 \\
\hline \multicolumn{2}{|l|}{ Portable Waste } \\
\hline chamber pot & 13 \\
\hline wastepaper basket & 8 \\
\hline \multicolumn{2}{|l|}{ Home Education } \\
\hline pencil, slate pencil & 155 \\
\hline pens and parts & 17 \\
\hline slate board fragments & 499 \\
\hline desk accessories & 75 \\
\hline misc. & 7 \\
\hline \multicolumn{2}{|l|}{\begin{tabular}{|l} 
Cleaning and Maintenance \\
\end{tabular}} \\
\hline \multicolumn{2}{|l|}{ Cleaning } \\
\hline chemicals & 1 \\
\hline tools & 4 \\
\hline Household Maintenance & 4 \\
\hline \multicolumn{2}{|l|}{ Laundry } \\
\hline clothespin & 39 \\
\hline misc. & 1 \\
\hline \multicolumn{2}{|l|}{ Sewing } \\
\hline pins & 686 \\
\hline scissors & 3 \\
\hline
\end{tabular}

\begin{tabular}{|l|r|}
\hline thimble & 2 \\
misc. & 6 \\
Pest Control & \\
mousetrap & 1 \\
Yard Maintenance & \\
tools & 1 \\
flower pot & 158 \\
Misc. & 1 \\
\hline Total Domestic & $\mathbf{3 3 , 5 4 3}$ \\
\hline
\end{tabular}

\begin{tabular}{|c|c|}
\hline \multicolumn{2}{|c|}{ ARCHITECTURE } \\
\hline $\begin{array}{l}\text { Construction } \\
\text { Materials } \\
\text { wood } \\
\text { window glass } \\
\text { paint } \\
\text { cement, mortar, plaster } \\
\text { shingles } \\
\text { adobe } \\
\text { brick } \\
\text { misc. } \\
\text { Hardware } \\
\text { nails } \\
\text { screws } \\
\text { door hardware } \\
\text { tacks } \\
\text { window hardware } \\
\text { staples } \\
\text { wire } \\
\text { nuts and bolts } \\
\text { washers } \\
\text { spike } \\
\text { rivet and burr } \\
\text { misc. } \\
\text { Misc. }\end{array}$ & $\begin{array}{r}37 \\
16,250 \\
129 \\
718 \\
455 \\
29 \\
45 \\
261 \\
\\
17,551 \\
285 \\
53 \\
843 \\
139 \\
181 \\
227 \\
36 \\
42 \\
10 \\
18 \\
56 \\
1\end{array}$ \\
\hline $\begin{array}{l}\text { Plumbing } \\
\text { Water Supply } \\
\text { pipe } \\
\text { misc. } \\
\text { Sanitation } \\
\text { waste pipe } \\
\text { misc. } \\
\text { Misc. }\end{array}$ & $\begin{array}{r}2 \\
4 \\
11 \\
1 \\
1\end{array}$ \\
\hline $\begin{array}{l}\text { Fixed Illumination and Power } \\
\text { Electrical } \\
\text { wire } \\
\text { insulation/insulator } \\
\text { fixtures } \\
\text { fuses } \\
\text { light bulb } \\
\text { misc. }\end{array}$ & $\begin{array}{r}14 \\
44 \\
1 \\
1 \\
10 \\
8\end{array}$ \\
\hline Total Architecture & 37,463 \\
\hline $\begin{array}{l}\text { PERSONAL AND DOMESTIC } \\
\text { TRANSPORTATION }\end{array}$ & 18 \\
\hline
\end{tabular}




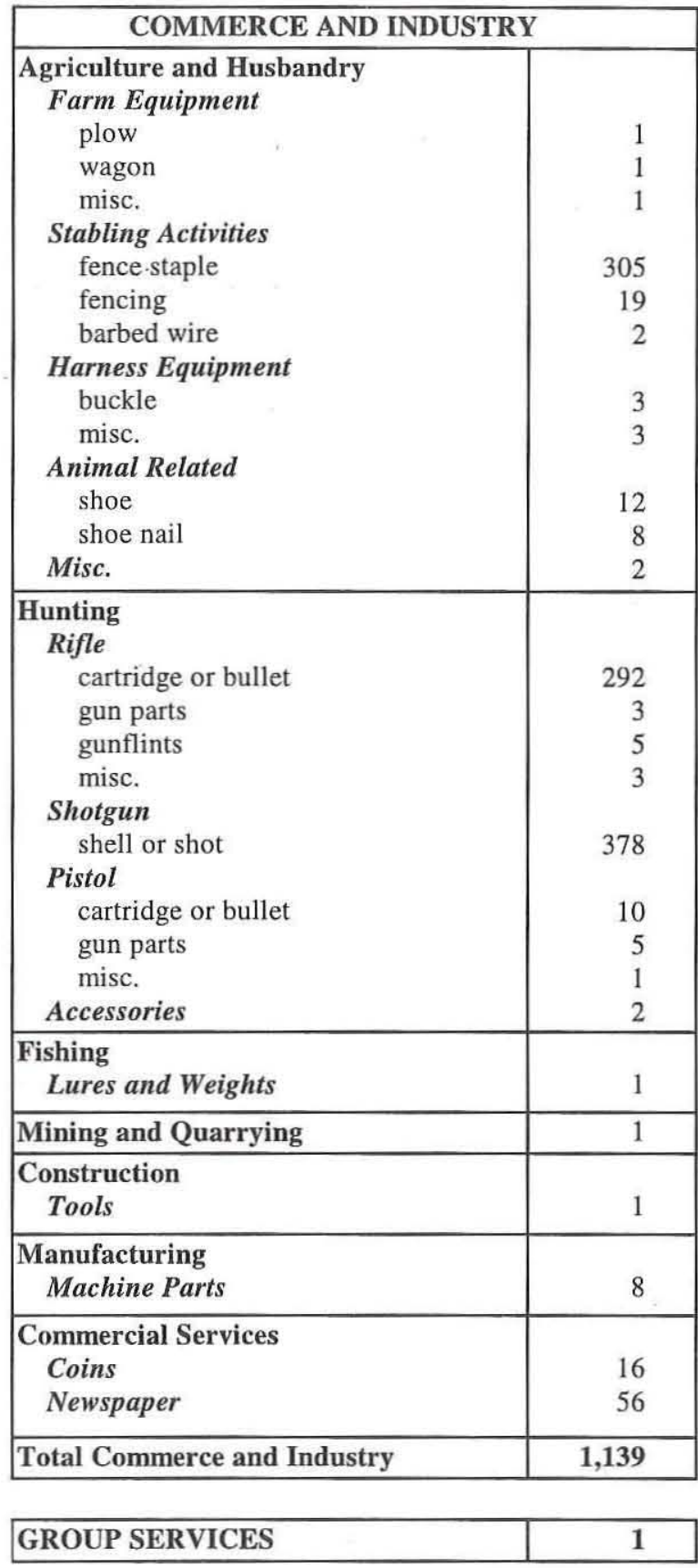

supplies, alcohol-related items, smoking-related items, gambling-related artifacts, personal religious items, pocket tools, keys, toys, infant supplies, and the like. Three of the artifact types included in the following analysis are from this group: dolls, smoking pipes, and marbles.

The Commerce and Industry group makes up 1 percent of the collection with 1,139 artifacts. This group includes farming-related artifacts, guns and ammunition, coins, newspapers, and other such artifacts. Arms and ammunition and coins are included

\begin{tabular}{|c|c|}
\hline \multicolumn{2}{|c|}{ UNKNOWN } \\
\hline Metal & \\
\hline Ferrous & 7,101 \\
\hline Cuprous & 288 \\
\hline White Metal & 139 \\
\hline Tin & 42 \\
\hline Aluminum & 22 \\
\hline Misc. & 4,958 \\
\hline Glass & 105 \\
\hline Ceramic & \\
\hline Porcelain & 2 \\
\hline Misc. & 8 \\
\hline Prehistoric & 2 \\
\hline Bone & \\
\hline Bone & 27,123 \\
\hline Teeth & 237 \\
\hline Bone and Teeth & 132 \\
\hline Artifact & 8 \\
\hline Misc. & 8 \\
\hline Ethnographic & \\
\hline Seeds & 405 \\
\hline Eggshells & 1,653 \\
\hline Fiber Matter & 7 \\
\hline Shell & 692 \\
\hline Leather & 33 \\
\hline Wood & 1,602 \\
\hline Soil & 151 \\
\hline Paper & 23 \\
\hline Misc. & 66 \\
\hline Lithics & \\
\hline Cultural & 172 \\
\hline Rock & 170 \\
\hline Fossil & 1 \\
\hline Coal & 1 \\
\hline Misc. & 2 \\
\hline Plastic and Rubber & \\
\hline Plastic & 237 \\
\hline Rubber & 67 \\
\hline Misc. & 5 \\
\hline Unknown & 87 \\
\hline Total Unknown & 45,549 \\
\hline GRAND TOTAL & 119,561 \\
\hline
\end{tabular}

in the detailed artifact analysis.

The remaining groups represented at Fanthorp Inn include Personal and Domestic Transportation and Group Services; however, the collections are extremely small. The Personal and Domestic Transportation group includes 13 car parts (primarily fan belt fragments), 1 miscellaneous tool, 1 miscellaneous supply-related artifact, and 3 railroad-related artifacts. The Group Services group is represented by one artifact, an election button for Democrat Judson Harmon. 


\section{GLASS}

The TPWD inventory identifies 19,856 glass artifacts and sherds as being related to culinary activities, 44 sherds as medical bottles, 3,214 sherds as lamp chimney glass, and 643 sherds as being related to gustatory activities (glass sherds identified as tablewares), totaling 23,757 glass artifacts and sherds. Two percent of these, or 568 artifacts, are sufficiently diagnostic to warrant description in this section. Buttons, marbles, and other artifacts made from glass are not discussed here.

\section{Bottles}

Analysis of the bottle glass is limited to complete bottles, embossed fragments with potentially identifiable patterns or series of letters, and selected finishes and bases identifiable to specific bottle types. The types of bottles described here are embossed bottles (patent medicine, graduated, cosmetic, and other), alcoholic beverage bottles, snuff bottles, canning jars and accessories, ink bottles, and unidentified intact bottles. Totals for these types are found in Table 2 .

\section{Embossed Bottles}

\section{PATENT MEDICINE BOTTLES}

One hundred thirteen diagnostic sherds and 2 complete bottles represent a minimum of 54 patent or The Pure Food and Drug Act was implemented in 1906. This law no longer allowed a "medicine" manufacturer to make false statements on a label and insisted that the label had to list the presence and amount of alcohol and specific narcotic drugs. In 1938 the Food, Drug and Cosmetic Act required that products be proven safe before being put on the market. This act also allowed the government to proprietary medicine bottles. These sherds, which could be identified to maker, medicine, or manufacturing location, are described below. Many more sherds are embossed with letters or parts of letters but are not identifiable and are not included here.

Patent medicines became most popular between the 1870s and the 1930s, and the Fanthorp bottles generally span this period (Table 3). Until 1906 these "medicines" were unregulated recipes of constituents ranging from herbs to narcotics (particularly cocaine and opium) and alcohol (Armstrong and Armstrong 1991:159-160). Although used by many strictly as medicinal treatments, for some, patent medicines took on the role of alcohol with the growth of the temperance movement and the implementation of Prohibition. Local laws sanctioned abstinence as early as the 1840 s, the first state prohibition was in Maine in 1851, Grimes County voted to implement Prohibition in 1905 (Texas State Historical Association 1996:346), and nationwide Prohibition was implemented on January 1, 1919, with the Eighteenth Amendment. Exceptions to the amendment were sacramental wines, liquor used for medicinal purposes, and that prescribed by a physician. It was not illegal to possess unauthorized alcoholic beverages, only to sell it (Armstrong and Armstrong 1991:44, 48). The legal patent medicines, often coming in large bottles but with instructions to take small dosages, provided a source of alcohol to people in areas where Prohibition was in place. With certain of these "medicines" having close to 50 percent alcohol content, some patent medicines became a viable replacement for the illegal alcohol. Nationally, Prohibition lasted until December 5, 1933, when the Twenty-first Amendment overturned the Eighteenth Amendment with a great deal of public support (Webb 1952:II:415).

Table 2. Analyzed Bottles and Bottle Sherds

\begin{tabular}{|c|c|c|c|c|c|c|c|}
\hline Bottle Type & $\begin{array}{l}\text { Finish } \\
\text { Sherds }\end{array}$ & $\begin{array}{c}\text { Base } \\
\text { Sherds }\end{array}$ & $\begin{array}{l}\text { Body } \\
\text { Sherds }\end{array}$ & $\begin{array}{c}\text { Embossed } \\
\text { Body/Base Sherds }\end{array}$ & $\begin{array}{c}\text { Jar } \\
\text { Liners }\end{array}$ & $\begin{array}{l}\text { Whole } \\
\text { Bottles }\end{array}$ & Totals \\
\hline Embossed patent medicine & - & - & - & 113 & - & 2 & 115 \\
\hline Embossed graduated & - & - & - & 17 & - & 3 & 20 \\
\hline Embossed cosmetic & - & - & 2 & - & - & 5 & 7 \\
\hline Other embossed & - & - & - & 9 & - & - & 9 \\
\hline Alcoholic beverage & 18 & 18 & 3 & 4 & - & - & 43 \\
\hline Snuff & 31 & 18 & 14 & 5 & - & 1 & 69 \\
\hline Canning jars & 29 & - & - & 16 & 11 & 1 & 57 \\
\hline Ink & - & - & 5 & - & - & - & 5 \\
\hline Unidentified intact & - & - & - & - & - & 25 & 25 \\
\hline Totals: & 78 & 36 & 24 & 164 & 11 & 37 & 350 \\
\hline
\end{tabular}


Fanthorp Inn State Historical Park

Table 3. Date Ranges for Patent Medicine Bottles from Fanthorp Inn

\begin{tabular}{ll}
\hline Bottles & Date Ranges \\
\hline Tricopherous & $1851-1873$ \\
Simmons Liver Medicine & n.d. \\
Simmons Liver Regulator & post-1868 \\
Pepsin Syrup (?) & post-1889 \\
Chamberlain's Pain Balm & $1873-1930$ \\
Chamberlain's Colic, Cholera, and Diarrhoea Remedy & $1882-1930$ \\
Dr. Kilmer's Swamp Root Kidney, Liver, \& Bladder Remedy & $1881-$ post-1924 \\
Jaques' Chemical Works & pre-1881 \\
Albolene (?) & $1889-1948 ?$ \\
Dr. J. Hostetter's Stomach Bitters & $1853-1958$ \\
American Cholagogue (?) & $1848-?$ \\
Squibb (company post-1857, machine made) & post-1904 \\
Vaseline & $1880-1955$ \\
Frazier's Distemper Cure & $1889-1916 ?$ \\
Sozodont (?) & $1866-1903$
\end{tabular}

Note: When possible, date ranges incorporate information for maker, medicine, and bottle style to provide the narrowest range.

The Pure Food and Drug Act was implemented in 1906. This law no longer allowed a "medicine" manufacturer to make false statements on a label and insisted that the label had to list the presence and amount of alcohol and narcotic drugs. In 1938 the Food, Drug and Cosmetic Act required that products be proven safe before being put on the market. This act also allowed the government to regulate cosmetics and diet aids for the first time. Labels now had to provide directions for use and warnings against misuse (Armstrong and Armstrong 1991:169-170). The age of patent or proprietary medicines was virtually over by World War II.

Most of the sherds described here are body panel sherds that do not necessarily show mold seams or base fragments. When a sherd has indications of the method of manufacture of the bottle, this information is included. The Bottle Book by Richard Fike (1987) is highly relied upon here for the identifications because it is the most comprehensive volume in this field. Also used was the computer program Embossed Medicine Bottle Labels Finding Aid by Dr. William J. Hunt Jr. of the National Park Service Midwest Archeological Center in Lincoln, Nebraska.

One glass sherd from a Tricopherous bottle was found (Figure 15a). Tricopherous was a hair tonic introduced in 1801, which was still on the market in 1982 (Fike 1987:122). The aqua-colored sherd found at Fanthorp does not contain any reference to the company that produced the product, but the composition of the lettering matches that made by Alexander C. Barry of New York, who was associated with the product from 1851 until 1873 (Fike 1987:122). This does not preclude the bottle dating later than 1873 .

Two aqua-colored sherds represent two bottles that contained Simmons liver medicine. One is embossed with ". . . PRIE . . / . . M. A. SI . . / LIVER ME ..." on the main panel, and the other has “. . . ETORS/ ... A. SIMMONS/ . . R MEDICINE." No mention of this product has been found in the literature, but a third aqua-colored sherd (a bottle neck and part of the body) has an indented panel embossed with "SIMMONS" and evidence of a second indented panel below and can be identified as a bottle that contained Simmons Liver Regulator (Figure 15b). According to Fike (1987:83), "Dr. A. Simmons, his daughter and grandson, Miles A. Thedford, manufactured and distributed the product [Simmons Liver Regulator] until selling to Smith \& McKnight in 1877. . . . Another of Simmon's [sic] children also sold the Regulator to J. H. Zeilin \& Co. ... in 1868." The third bottle fiagment is the product made by J. H. Zeilin \& Co. of Macon, Georgia, and Philadelphia, and postdates 1868 (Fike 1987:83).

One machine-made bottle represented by three aqua-colored sherds has ". . . B. Caldw. ..." embossed on it with the remains of another initial in front of the "B." Dr. William Burr Caldwell produced a pepsin syrup starting in 1889 (Fike 1987:224). The label noted by Fike, however, does not have the initials before the last name, so it is not clear if pepsin syrup or another substance was contained in this bottle.

One sherd of an aqua-colored bottle was found with ". . . T OF/. . . RILLA" embossed. This is likely 


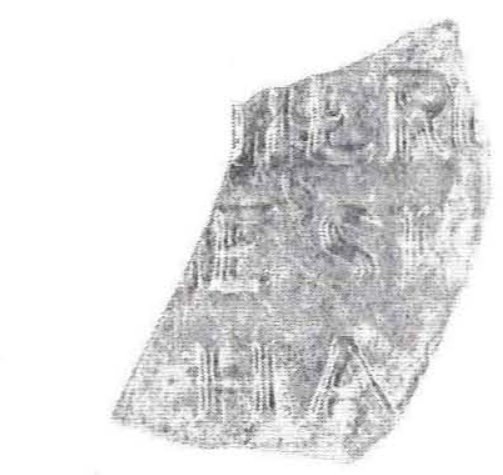

a

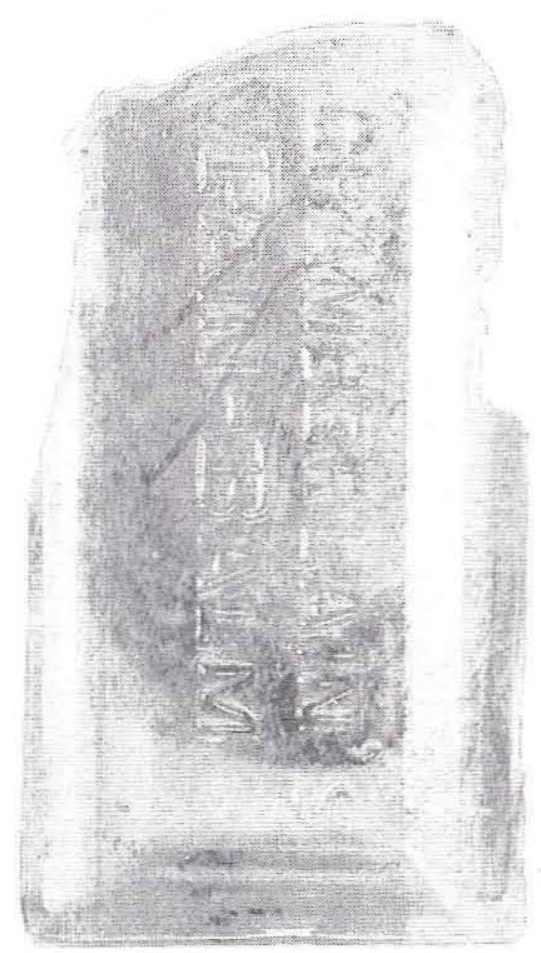

C
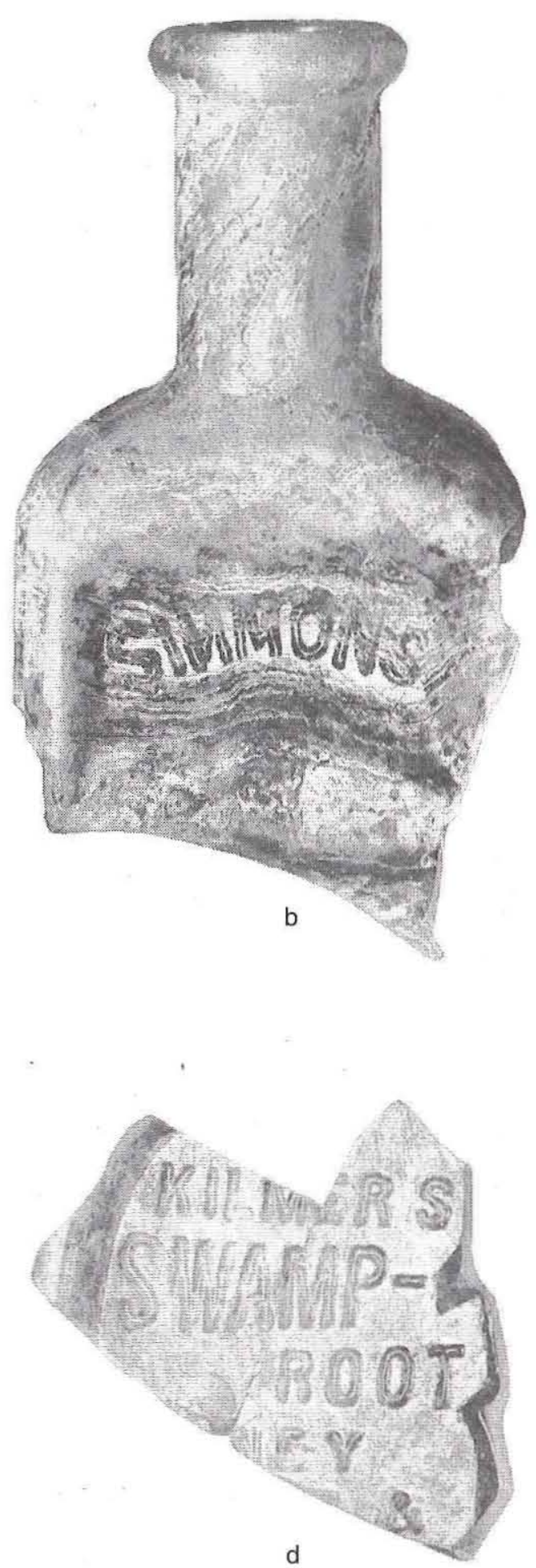

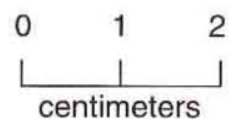

Figure 15. Embossed patent medicine bottles. (a) Tricopherous Hair Tonic; (b) Simmons Liver Regulator; (c) Chamberlain's Pain Balm; (d) Kilmer's Swamp Root Kidney, Liver, and Bladder Remedy. 
an extract of sarsaparilla bottle. Because there were many brands, a date range for this bottle is not given in Table 3.

One Chamberlain's Pain Balm bottle sherd was found (Figure 15c). Chamberlain's was a business formed by brothers Davis and Lowell Chamberlain in 1873 in Marion, Iowa. The business moved to Des Moines in 1881, at which point the company became Chamberlain and Company. In 1892 the name changed to the Chamberlain Medicine Company. The medicine branch of the firm was sold in 1930 while the Chamberlains concentrated on cosmetics. The side panels of this bottle, which would have had the company name and location on them, are missing, so the dates for the bottle are not easily determined; the Pain Balm was available in 1880, however (Fike 1987:206). The bottle is of the two-piece, cup-bottom, mold-blown variety. Also found at the site was a sherd from a Chamberlain's Colic, Cholera, and Diarrhoea Remedy, which was introduced in 1882 (Fike 1987:205). Only a small sherd of the embossing from this bottle was found. One small aqua-colored sherd with only “. . . AIN'S" embossed on it also was found; it is assumed to be from a Chamberlain's bottle as well.

Three sherds from a Dr. Kilmer's Swamp Root Kidney, Liver, and Bladder Remedy medicine bottle were found (Figure 15d). This herbal medicine was introduced in 1881 by Andral and Jonas Kilmer of Binghampton, New York. The formula was marketed as "A Diuretic to the Kidneys and Mild Laxative" (Fike 1987:Plate 46). From a partially readable label in Fike (1987:Plate 46), the following contents are indicated: "B . . . Leaves, Peppermint Herb, Rhubarb Root, Mandrake Root, Cape Al . . , Skullcap Leaves, Colombo Root, Golden Seal Root, Valerian Root, Sassafras, Cinnamon; and Oil of Juniper, Oil of Birch, ... incorporated in a syrup base." This bottle label is from what appears to be a later version of the medicine (1920s?) and indicates an alcohol content of 10 percent. The Kilmer brothers produced a line of "family remedies," including "Indian Cough Cure, Autumn Leaf Extracts for Females, Ocean Weed Heart Remedy, Prompt Parilla Liver Pills, and the hotselling Swamp Root" (Armstrong and Armstrong 1991:166) and were in business until after 1924 (Fike 1987:208).

A bottle sherd from Jaques' Chemical Works in Chicago was found in Cistern 2. Fike (1987:65) notes that Frank F. Jaques and Myron W. Atwood established a business in Chicago in 1882, which was to become Atwood \& Steefe in 1889. It is not clear when Jaques was producing material on his own, but it seems that the bottle found at Fanthorp probably predates 1881. The bottle is aqua in color and was mold blown in a two-piece cup-bottom mold. The contents of this bottle are unknown.

Six fragments of an aqua-colored case bottle were found. One side has "A L B ..." embossed on it. This may have contained Albolene, a substance identified as being advertised in 1889, 1929-1930, and 1948 (Fike 1987:151). There is little information beyond this for this product.

Thirty fragments of two bottles that once contained Dr. J. Hostetter's Stomach Bitters are present. This patent medicine was very popular and widely used. First produced for public consumption in 1853, Hostetter's formula was last marketed in 1958 as Hostetter Tonic. The alcohol content of Hostetter's Stomach Bitters was as high as 47 percent, but with the passage of the 1906 Pure Food and Drug Act, the alcohol content was reduced to 25 percent (Fike 1987:36), still containing about half the alcohol content of whiskey and much more than beer. In the Alaskan territory, where distilled spirits were prohibited from being imported, bitters became a substitute for alcohol for many people, with many establishments selling the "medicine" by the glass (American Medical Association 1912:740). These bottles were amber-colored case bottles $9.5 \times 3 \times 3$ inches in size, but other bottle shapes were also used.

Two cross-mending sherds of a colorless bottle were excavated. The sherds display ". . . ERICAN/CH ..." which may represent an American Cholagogue bottle by Jones of New York (Hunt 1995). This formula was marketed in 1848 as a remedy for malarial diseases, fevers, and ague (Fike 1987:168).

One bottle is embossed only with "SQUIBB" on both the front and back shoulders. The bottle is machine made with "MADE IN U.S.A." in a circle around a " 7 " on the base. The bottle is $12.1 \times 6.3 \times 3.2 \mathrm{~cm}$ in size and has a rounded lip with a flat string rim. The Squibb Pharmaceutical Laboratory was established in 1857, and the company is still in operation today as E. R. Squibb \& Sons, Inc. (Fike 1987:182).

Six sherds from six Vaseline bottles were found. Although vaseline could also be included under cosmetic bottles, this product started out as a proprietary medicine. All six sherds are colorless and are from jars of vaseline made by the Chesebrough Manufacturing Company of New York. Robert A. Chesebrough discovered in 1859 that a byproduct of oil drilling could be used to treat minor wounds and bruises. In the $1860 \mathrm{~s}$, after refining the product, Vaseline was on the market. The Chesebrough Manufacturing Company Consolidated was founded in 1880 and operated until 1955 when it merged with 
Pond's Extract Company (Fike 1987:56). The Fanthorp bottles date between 1880 and 1955 based on the embossing, and they more likely date to the twentieth century due to the style of the letters, the clarity of the glass, and, on at least one of the sherds, the evidence of machine manufacture. Four of the sherds were recovered from Cistern 2, one from Room 111; and one from the north side of the house. Five additional colorless finish fragments (three from Cistern 2 and two from the north side of the house) appear to be from jars of the same size as the Vaseline bottles, although none cross-mend with the embossed sherds. All of the finish sherds have mold seams that run over the finish or around the bottom of the finish indicating machine manufacture (either semiautomatic or automatic).

One bottle embossed with "FRAZIER'S DISTEMPER/CURE/NAPPANEE, IND." was found (Figure 16a). The bottle stands $18.6 \mathrm{~cm}$ tall, and the rectangular body is $4.1 \times 6.7 \mathrm{~cm}$. It is a colorless, mold-blown bottle with a prescription finish, one indented panel, and chamfered corners. A smaller bottle with the same embossing is identified in Fike (1987:98) as being advertised in 1889 and 1916 even though the word "cure" had been banned in 1906 (Fike 1987:4).

Three sherds of colorless bottles found in different locations probably came from Sozodont bottles. One sherd is embossed with "... KIRK'S," a second with "FRAGR ...," and a third with "... ODON...." Sozodont was a tooth powder which was advertised between 1866 and 1903 (Wilson 1981:134)

A number of sherds have embossing that is too fragmentary to allow positive identification of the maker or the contents. Four sherds represent a single colorless bottle; although not all cross-mend, the reconstructed part of the embossing appears to read "ORI . . BROS./CHEMISTS/ST ... MO." Two aqua-colored sherds represent different bottles of an unidentified product; the more complete sherd reads “... R. R. .../. . OWAY .../. . . W YO...." Three cross-mending sherds from a colorless bottle shoulder read "THE TUBE OF THIS .../IS MADE OF ON. . .PAT MAY 8...." One olive-colored sherd has only "... ITTERS" and probably represents a bitters bottle. Three colorless bottles represented by five sherds have embossed letters indicating that they contained syrups of some sort. One colorless sherd has the remains of the word "CHEMICAL" embossed, another has part of "MEDICINE," a third has "FLUID OZ," and a fourth has "... M EAGLE. ..." One aqua sherd has only ". . . ACOR ..." embossed, one has “. . . PROVED . . .," two cross-mending sherds have
“... A C [or G] ... J [or U] R," and one is embossed with "LATOR." One colorless sherd has "J. P. . . ./D ..." while another has only "... LEY" remaining. Two last aqua-colored sherds combine to show part of "INFA ..." embossed. Finally, 18 sherds represent a minimum of nine bottles with only location names embossed on them. These include bottles from Kentucky (probably Louisville), Georgia, Minneapolis (probably), possibly Mexico (embossed "MEX"), two from Chicago, and three from New York.

Of the 54 patent medicine bottles discussed in this section, 26 are identified to maker or contents and 31 are identified to state (and in one case possibly country) of manufacture. With the exception of one bottle, which may have come from Mexico, all of the patent medicines represented in the Fanthorp collection came from the United States. The largest number of bottles came from New York, with a total of 15 . Illinois is represented by four bottles, Iowa by three, and Pennsylvania by two. States represented by one bottle each are Connecticut, Indiana, Missouri, Kentucky, Georgia, and Minnesota. Twenty-three bottles are not identifiable to location of manufacture.

\section{GRADUATED BOTTLES}

Graduated bottles, or those that have measurements embossed on them (Jones and Sullivan 1989:85), would have held medicines and been labeled with paper. The contents of these bottles cannot be known from their markings. The measurements are all marked in "cc"s, or cubic centimeters. A minimum of 5 bottles (all colorless) is represented by 3 complete bottles and 17 sherds.

Two complete 50 -cc bottles, $11.4 \times 2.5 \times 4.4 \mathrm{~cm}$, were blown in two-piece cup-bottom molds. They have rounded prescription lips and cross sections of which one half is oval and the other is half of a hexagon (ovoid-hexagonal). One has an embossed "3" on its base.

A nearly complete 80 -cc bottle represented by seven sherds was machine made. This bottle stood $12.7 \mathrm{~cm}$ tall and was $3.2 \times 4.8 \mathrm{~cm}$ in cross section. The cross section of this bottle is almost a Philadelphia oval, but the corners are more pronounced creating a more rectangular bottle. The very faint remains of a multiple-digit number are on the base. A rounded prescription lip is situated above a flattened string rim, and the shoulders of the bottle are fluted.

One complete machine-made graduated bottle with a threaded finish and a bead string rim was found. This bottle is over $100 \mathrm{cc}$ in size, stands $14.6 \mathrm{~cm}$ tall, and is $3.5 \times 5.7 \mathrm{~cm}$ in cross section. The cross section of the bottle is a Philadelphia oval. The base has an 


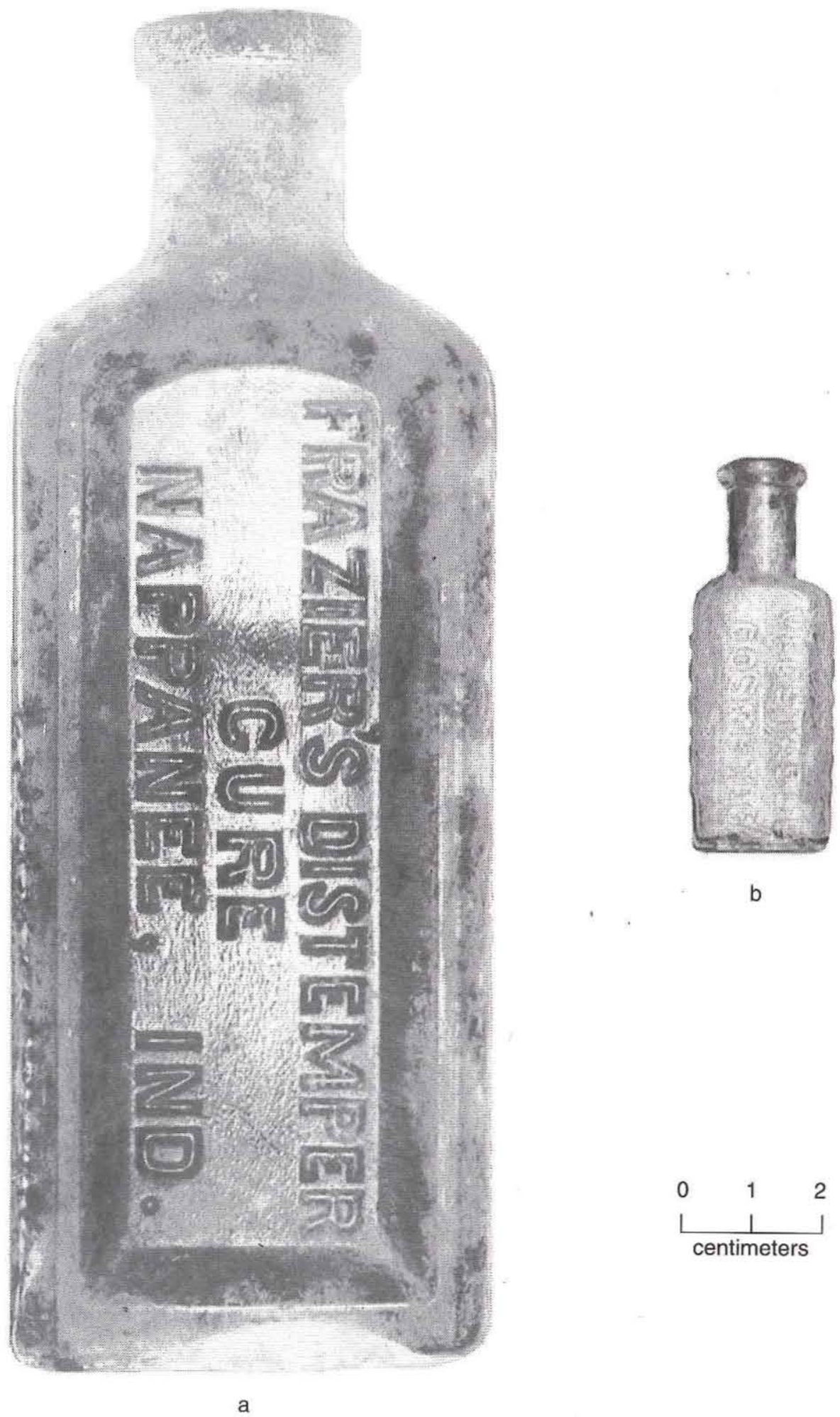

Figure 16. Other embossed bottles. (a) Frazier's Distemper Cure; (b) Palmer's Vegetable Cosmetic Lotion. 
Owens scar and is embossed with a " $\mathrm{K}$ " within a keystone and a "3." The " $\mathrm{K}$ " within the keystone was a mark of the Knox Glass Bottle Company (after 1956 the Knox Glass Co., Inc.) of Knox, Pennsylvania, and was used from 1924 to 1968 (Toulouse 1971:293).

Only the finish and neck of a fourth bottle were found. This was also a machine-made bottle as evidenced by the seams on and around the finish. This is a rounded prescription finish above a wide flattened string rim, which would have been sealed with a cork.

Nine other colorless sherds with markings similar to those on the graduated bottles were also found. All are body sherds.

\section{COSMETIC BOTTLES}

One cosmetic bottle embossed "PALMER'S// VEGETABLE/COSMETIC//LOTION" was recovered (Figure 16b). It is $5.7 \times 1.9 \times 1.3 \mathrm{~cm}$ in size, is rectangular with chamfered corners, and has a prescription finish with a $1.3-\mathrm{cm}-$ long neck. The bottle was mold blown.

A second cosmetic bottle is embossed with "Cutex/40" on the base and " 5 " on the side. This is a small nail polish bottle that was machine made with a rectangular cross section and chamfered corners. The bottle is $4.4 \times 1.9 \times 1.6 \mathrm{~cm}$ in size. The finish is not threaded, and the lip is rounded.

Two complete jars and two sherds representing a minimum of three cobalt blue jars were excavated. The two complete jars measure $4.5 \mathrm{~cm}$ in diameter and $6.2 \mathrm{~cm}$ high. These jars are all machine made with threaded finishes and have similar base marks with two nested triangles, a dot to the side of the triangles, and a number underneath (63, E6, and ...44). These bottles look like Vicks VapoRub or Mentholatum jars. A white-glass Mentholatum jar was also found. It is $5.1 \mathrm{~cm}$ tall with an external diameter of $3.8 \mathrm{~cm}$. This jar was machine made and has a smooth lip (not cracked-off). Embossed on the base is "MENTHOLATUM/REG/TRADE/MARK." A very small, unreadable portion of a paper label remains on the body.

\section{OTHER EMBOSSED BOTTLE FRAGMENTS}

Embossed bottle fragments that do not represent patent medicine, graduated, or cosmetic bottle fragments include seven Coca-Cola bottle sherds and two fragments of laundry bluing bottles. Although the Coca-Cola bottle sherds do not all cross-mend, they could come from the same bottle. The Coca-Cola bottle sherds are aqua and display the classic hourglass shape that was adopted in 1916 (Spillman
1983:\#59). One of the body sherds, just below the Coca-Cola logo, is embossed with "... MARK REGISTER . . . . . CONTENTS 6 FL OZ. ...” Also embossed on two cross-mending sherds is ". . . RTY OF C. ..."

One large aqua-colored sherd from a laundry bluing bottle was found with "FR .../M.BI X $8 \ldots$. /BLUE" embossed on it. The " $\mathrm{X}$ " in the middle is larger than the other letters. A blue glass sherd, appearing to be a bottle base, has the same large " $\mathrm{X}$ " behind "BI," so it is assumed that these two bottles contained the same product.

\section{Alcoholic Beverage Bottles}

No complete alcoholic beverage bottles were recovered; only 18 finish, 22 base, and 3 body fragments are described here. These pieces are distinguished by their color (dark green or amber in most cases) and by their morphology. Dates for these bottles range from the late eighteenth century to the mid to late nineteenth century. No twentieth-century alcohol bottles were recovered, possibly because Grimes County was voted dry in 1905 (Texas State Historical Association 1996:346). Distinguishing between wine and beer bottles from the early part of the nineteenth century is not possible from finishes alone. In many cases, even having the entire bottle does not guarantee knowledge of the contents because the typical "wine" bottle could contain ". . . wine, porter, ale, cider, distilled liquors, and other products" (Jones 1986:9). All alcoholic beverage bottles are grouped together here, and for the early ones "wine" bottle refers to their shape, not contents. When an inference about contents other than wine has been made, this is stated.

\section{FINISHES}

The lip of the English wine bottle from the midseventeenth century to the 1760 s was either cracked off or fire polished and had an applied string rim. Between the 1760 s and the 1820 s, a shift occurred, and by the 1820 s the lip (not just the string rim) was consistently formed from added glass. As time went on, the lip became taller and wider, becoming the dominant feature of the finish over the string rim (Jones 1986:33). Therefore, the morphology shifted from a simple tube of glass with a string rim not made with a finishing tool (up to the 1820s) to a complex finish with a pronounced lip and a string rim formed with added glass and a finishing tool (used as early as the $1820 \mathrm{~s}$, and a standard piece of equipment by the second half of the nineteenth century) (Jones 
1986:45-46). All of these dates relate to English-made wine bottles, not Dutch or French, which may skew the dates some if any of the present specimens are not English.

One pale green bottle neck and finish was found with a slightly heat polished, cracked-off lip and a rounded trail string rim (Figure $17 a$ ); it predates the 1820 s, as the lip is not made with added glass. Jones (1986:44) also states that "examples of string rims of indeterminate shape, generally a thin thread of glass, were observed dating from the mid- to the end of the 18th century." Of the crackedoff lip, Jones and Sullivan (1989:80) comment: "This type of lip is found on 18th century dark green glass English and French 'wine' bottles, on 18th century French 'blue-green' narrowmouthed containers, and continues to appear in the 19th century," insinuating that the French and English production were similar at that time.

One olive-colored bottle finish has a cracked-off, flat-topped lip and a flattened string rim dating it to 1760-1820 (Figure 17b). This sherd resembles the typical "champagne" finish. The bore diameter is $2.1 \mathrm{~cm}$ and is very symmetrical. The extant portion of the neck is very straight with a diameter of 2.8 to $3.1 \mathrm{~cm}$. A ridge on the interior of the neck just at the bottom of the string rim was created to facilitate a seal with the cork. The flattened string rim became popular in the 1760s and is still in production today. Since the lip is neither fire polished nor has added glass, this piece predates 1820 (Jones 1986:33, 43).

One wine bottle finish fragment made of green glass has a symmetrical groove between the downtooled lip and the flattened string rim on the exterior of the finish (Figure 17c). This particular style, produced with a finishing tool, has been found in contexts dating 1835-1855 (Jones 1986:71). The lip and finish are made of added glass, which is distinct from the cracked-off bottle glass in profile. The added portion stands $1.8 \mathrm{~cm}$ above the original crack-off. A similar fragment of an amber-colored finish also has a groove between the lip and the string rim on the exterior. The lip is too fragmented to identify its morphology, but the string rim is beaded or rounded. The finish, created from added glass, postdates 1820 .

On one wine bottle finish fragment, the interior
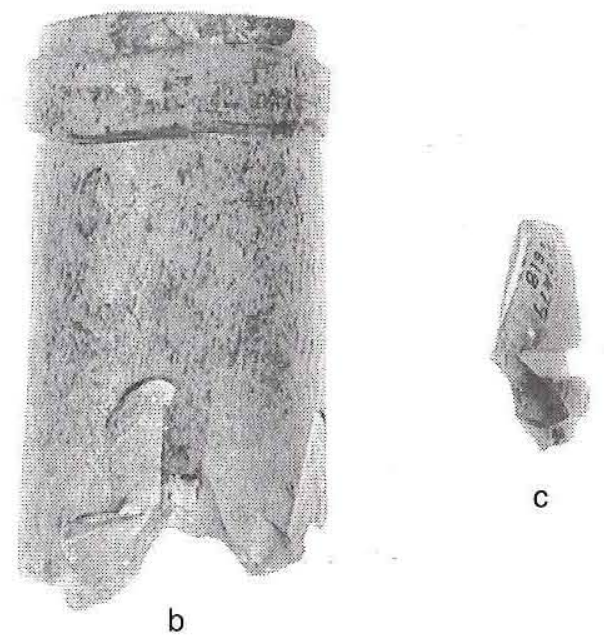

centimeters

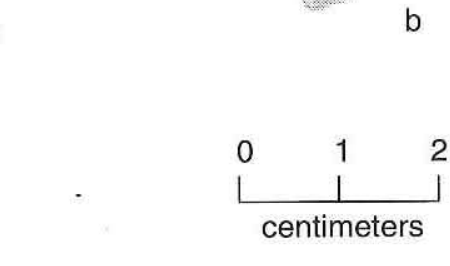

(a) Pre-1820s bottle finish; $(b)$ "champagne" finish ca. 1760-1820; (c) post-1820 wine bottle finish fragment with groove between lip and string rim.

neck and the applied glass that formed the lip and string rim are visible. The shape of this fragment does not provide enough of the finish to know how it was made, but the string rim was down-tooled. It appears that the finish was made with a finishing tool, dating it after 1820 but more likely to after the midnineteenth century into the early twentieth century (Jones 1986:46).

Two fragments of what appear to be champagne finishes with flattened string rims were found. One is definitely from a champagne bottle and was made with a finishing tool, dating it after 1820 . The other is of questionable origin because it is small for a champagne bottle, but it appears to also be a champagne finish, possibly from a wine bottle. Both are made of olive green glass. One olive-colored finish has a rounded-side lip and a down-tooled string rim. The finish was made with added glass and was shaped with a finishing tool. This piece also postdates 1820 .

An amber-colored finish fragment has a downtooled lip (1.3 cm tall) and a down-tooled string rim. The finish was applied with a finishing tool and was likely made with added glass. An olive-colored finish was also found with a down-tooled lip and a downtooled string rim. This piece appears older than the amber version, and the lip is much taller, being $1.9 \mathrm{~cm}$ in height. This finish also appears to have been made with added glass and shaped with a finishing tool. 
Similar in height to this last finish is an amber-colored finish and neck fragment with a down-tooled finish and a V-shaped string rim. The neck does not show any signs of mold seams, and it is not clear whether the finish was made with added glass, but it was shaped with a finishing tool.

Fragments from two amber-colored bottles with down-tooled lips and V-shaped string rims were recovered. Both finishes were made with added glass and were shaped with a finishing tool. The one finish with a corresponding (but not cross-mending) body sherd in association shows mold seams on the body, indicating a mold-blown bottle with a hand-applied lip. The other finish is broken off at the string rim and does not have any part of the neck attached to show mold seams. Similar to these two finishes is an amber finish with a down-tooled lip and a rounded or beaded string rim. This piece also appears to have been made with added glass and a finishing tool.

One olive green finish is rounded with no string rim. This was made with added glass and was shaped with a finishing tool. One amber-colored fragment has a down-tooled lip and is $2.5 \mathrm{~cm}$ tall. Because of the way it is broken, it is impossible to tell if there was a string rim. It is also impossible to tell if the finish was made with added glass. One sherd of a string rim of black (very dark olive) glass was found. This piece is very thick and exhibits characteristics of a finish made with added glass and shaped with a finishing tool. The string rim is rounded.

\section{BASES}

Two embossed base fragments, likely from bottles made in Ricketts molds, were found. The first of these is from the Willington Glass Works in West Willington, Connecticut. The company was in production from 1815 to 1872 , but its most prosperous period ended in 1857. No marked bottles were produced prior to 1849 , making the most likely date range for this bottle between 1849 and 1857 , but possibly as late as 1872 . This base is made of black glass (extremely dark olive-amber) and is $7.3 \mathrm{~cm}$ in diameter. A small amber-colored sherd also appears to be from a Ricketts-style mold. The sherd is too small to see any words, but a "C" is embossed on it.

A rectangular bottle base has a glass-tipped pontil mark. The edges of the base are broken, but it appears to have had chamfered corners. Although this bottle appears to have been molded, there are no seams to indicate this.

One base is from a round, blown, black glass bottle. The push-up was created with a six-pointed star-tipped rod, and the pontil appears to have been a sand pontil although reheating of the base has blurred the mark. The base is broken but appears to have been ca. $7 \mathrm{~cm}$ in diameter. A small sherd from the base of a black glass bottle shows part of a pontil mark and appears to have been part of a fairly steep push-up. Although it appears old, there is no way to accurately date this fragment. Two round bottle bases have ironrod push-up marks and sand pontils. Each is made of very dark olive glass (black glass); one is $6.5 \mathrm{~cm}$ in diameter, and the other is nearly $8 \mathrm{~cm}$ in diameter. These are nineteenth-century bottles (Jones 1971:70). One olive- and two amber-colored bottles are represented by three basal sherds, each made up of portions of the heel, body, and push-up. These sherds indicate tall push-ups for all of the bottles but provide little other information.

Two very dark olive-colored base sherds have shallow push-ups. One bottle was around $6.5 \mathrm{~cm}$ in diameter, the other was about $7 \mathrm{~cm}$, and both were free-blown. Pontil marks are not visible. Two green glass sherds appear to be hollow mamelons from the push-ups of mold-blown champagne bottles. These sherds do not give any indication of the height of the push-up or the size of the bottle. One amber-colored bottle base (without a push-up) is embossed "E. G. Co/17." This mark is identified in Toulouse (1971:176) as being from the Excelsior Glass Company of St. Johns, Canada, but in this context and on this bottle form, this source seems unlikely. This was probably a beer bottle made in a mold and is $6.6 \mathrm{~cm}$ in diameter. Another flat-bottomed, ambercolored bottle base fragment is embossed with a " 5 " and has a diameter of around $7 \mathrm{~cm}$. One ambercolored sherd is from a base that was ca. $7 \mathrm{~cm}$ in diameter and had a very shallow push-up, and an amber-colored sherd is from a base that was approximately $6.5 \mathrm{~cm}$ in diameter and had a flat bottom. One olive/amber-colored base with a shallow push-up and a mamelon in the center is from a bottle approximately $7.5 \mathrm{~cm}$ in diameter.

\section{PICNIC FLASK}

Six sherds (the finish and neck, three base sherds with substantial parts of the body, and two body sherds) represent a partially reconstructable picnic flask of clear glass. The bottle was blown in a twopiece cup-bottom mold. The oval base measured $5.7 \times 3.3 \mathrm{~cm}$, and the bottle was $16.5 \mathrm{~cm}$ tall.

\section{Snuff Bottles}

The remains of at least 32 snuff bottles are represented by 68 sherds and 1 whole bottle (broken 
colored. Two machine-made bottles are represented by two base sherds and possibly one finish sherd. One basal sherd shows a pontil mark and was free-blown. The other 29 bottles were either mold-blown or could not be identified by manufacturing technique.

Three sherds are from three dark olive-colored, rectangular bottles from E. Roome of Troy, New York (Figure 18a) (Hunt 1995:346). These bottles likely predate the mid-1860s. No further information regarding the company or the contents was found, although Munsey (1970:78) shows snuff bottles of this shape. One of these sherds also includes the base of the bottle, on which can be seen the pontil mark with a rod of glass embedded in it and a mold seam running diagonally through its middle. This is evidence of a bottle blown in a two-piece hinge mold that was held with a glass-tipped pontil as the finish was applied. This indicates a bottle made prior to the use of the snap case which was standard by the mid1860s (Munsey 1970:48). This bottle is $4.8 \times 7.1 \mathrm{~cm}$ in cross section and has chamfered corners, but not enough remains to determine its height. Two other sherds of one snuff bottle body and finish are the same color and shape and have the same dimensions as these Roome bottles. The height of this bottle is approximately $11 \mathrm{~cm}$.

One amber-colored basal sherd shows an iron rod pontil mark (Figure $18 b$ ). This piece is approximately
$6 \mathrm{~cm}$ square and is heavily patinated. Two sherds making up a complete amber-colored snuff bottle were found in the Dry Well II excavation. The dimensions of this mold-blown bottle are $5.6 \times 5.6 \times 10 \mathrm{~cm}$. There are no markings on the base. The two machine-made amber-colored base sherds in this collection are both $5.75 \mathrm{~cm}$ square. One of these is embossed with a "4," and the other is embossed with a " 5 ." One amber moldblown bottle base, represented by three sherds, is also $5.75 \mathrm{~cm}$ square and has two raised dots. Another amber bottle is represented by one finish and two body sherds and is also $5.75 \mathrm{~cm}$ square. Of the remaining 54 sherds, 14 are amber base sherds, 21 are amber finish sherds, 8 are olive finish sherds, and 11 are amber body sherds.

\section{Canning Jars and Accessories}

Twenty-nine finish fragments, 16 embossed body and basal fragments, and 4 sherds from a complete jar represent a minimum of 24 canning jars. Eleven sherds represent a minimum of 8 liners. Of the finish sherds, three representing separate jars were made by the cracked-off method indicating mold-blown manufacture; the remainder were made in either semior fully automated machines. The use of semiautomatic machines in the production of wide-mouthed containers began in 1893, peaked around 1917, and ended in 1926 (Miller and Sullivan 1991:110). The

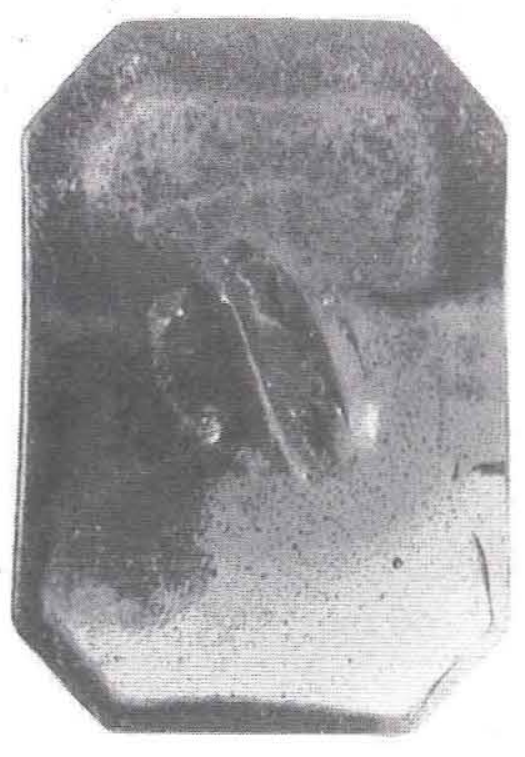

a

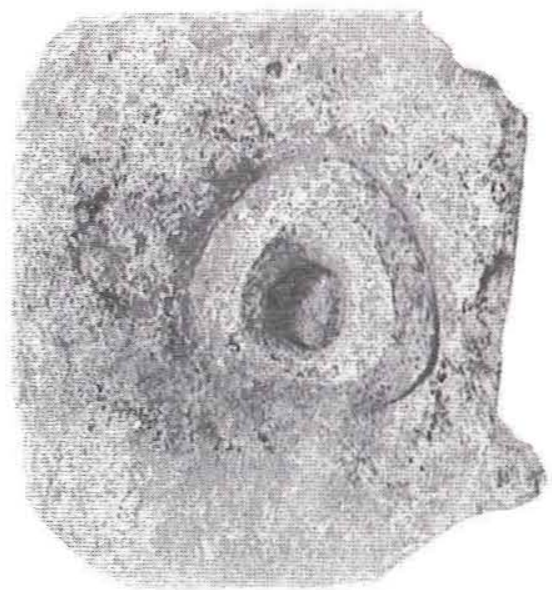

b

Figure 18. Snuff bottle bases. (a) E. Roome, Troy, New York, bottle base with glass rod pontil mark; $(b)$ base showing iron rod pontil mark. 
containers began in 1893, peaked around 1917, and ended in 1926 (Miller and Sullivan 1991:110). The mold-blown jars likely predate 1900 . Closure types represented on these finish sherds include 21 sherds with threads, 2 with lugs, 1 snap-type closure, and 5 that are too small to be identified.

Of the eight liners, three are the style that would have lined a full-topped screw-on lid. One of these is embossed around the seal edge with "GENUINE ZINC CAP/ ... RS." All three of these liners are $6.5 \mathrm{~cm}$ in diameter and are made of milk glass. Three sherds of at least one colorless glass liner used with a lightning closure were found. One Ball brand liner with "Ball" (in script and underscored) embossed on its upper surface was also found. This liner would have been held in place with a metal ring (zinc or, after World War II, tin plate). The final liner sherd is small. The method of securing this liner to the jar is not known; it may have lined a full metal lid, been held on with a ring, or been held in place with one of the other myriad devices used for this purpose.

From the 16 embossed body and basal fragments, 9 canning jars are represented. Two colorless cross-mending sherds come from a Presto Supreme Mason jar which was made from ca. 1935 to 1946 by both the Owens Illinois Glass Company and the Illinois Pacific Glass Company (Toulouse 1969:248). Four sherds from two Drey jars were found. The first, represented by three sherds, is a Drey Square Mason similar to a jar shown in Toulouse (1969:100) and dated ca. 1920-1925, but lacking the carpenter's square above "MASON" (Brantley [1975:29] shows similar markings on a small jar which also lacks the square). Drey jars were made by the Schram Glass Manufacturing Company, which was purchased by Ball in 1925. The Drey Perfect Mason and the Drey Square Mason were made for a while by Ball after they purchased Schram (Brantley 1975:28), suggesting that they may have been made for a time after 1925. The second colorless Drey jar sherd appears to have been from one of their Perfect Masons. The date for this jar could be anywhere from ca. 1910 to ca. 1925 (Brantley 1975:28; Toulouse 1969:99). Three sherds from a Ball Perfect Mason were recovered. The Perfect Mason was a threaded canning jar that became one of the major items in the Ball line. This jar, being made in an Owen's machine (dating it to after 1909) and not having gripper marks (a standard after 1933), dates 1909 to 1933 (Brantley 1975:18, 30). Two sherds from the bottom of a Kerr jar with "...D SPRINGS, OKLA .../. . 915/3" embossed was found. Kerr opened a plant at Sand Springs, Oklahoma, in 1912, and when the sales office was moved to that location in 1915, the bottom mark was changed
(Toulouse 1969:167). The "915" on the base, likely 1915 , does not necessarily imply a production date but was undoubtedly used over many years designating that move. One colorless sherd of a Ball jar was found showing the double "l" of the name and part of the underscoring attached to the last "l." The upward script of the Ball name was used after 1896 (Brantley 1975:13). Two colorless cross-mending sherds from one jar are embossed with ". . . ONE QUART . . ./. . . REG. C...." Two sherds, one colorless and one amethyst, were also found with illegible embossing.

One complete jar, represented by four sherds, was found. This is a round Ball Ideal jar with the patent date of July 14, 1908, embossed. This jar was made in an Owens machine dating it to after 1909 (Brantley 1975:18) and most likely 1915-1920 (Toulouse 1969:29). The closure is of the lightning variety with a half-round lug for bail attachment (Figure 19).

\section{Ink Bottles}

Five sherds from a minimum of two paneled conical (umbrella) ink bottles were found. Three of the sherds are a dusty green color, while the others are amber. These bottles were mold-blown. The umbrella style was popular from the 1820 s to the 1880 s (Munsey 1970:120).

\section{Unidentified Intact Bottles}

Over the years, many bottles have been misidentified by historical archeologists by being included in a pharmaceutical category. Cosmetic bottles, household cleaning items, hair tonics, boot blacking, dyes, inks, homeopathic medicines, patent medicines, prescription medicines, and a host of other items can all come in similar bottles although they have very different functions. Most of the unidentified complete bottles found here could be classified this way. This classification is not accurate unless there is some evidence (a label, embossing, or residue analysis) identifying the original contents of the bottle. So although many of the bottles described in this section may appear to be pharmaceutical bottles, they are not called such as there is not enough evidence to make this classification.

Twenty-five intact bottles unidentified regarding contents were found in the Fanthorp Inn archeological deposits. Of these, 16 were machine made and date to the first half of the twentieth century. Makers of the machine-made bottles identified by marks on their bases include the Illinois Glass Company (19161929), the Owens Illinois Glass Company (post1929), the Brockway Machine Bottle Company (post1925), and the Hazel Atlas Glass Company (1920- 


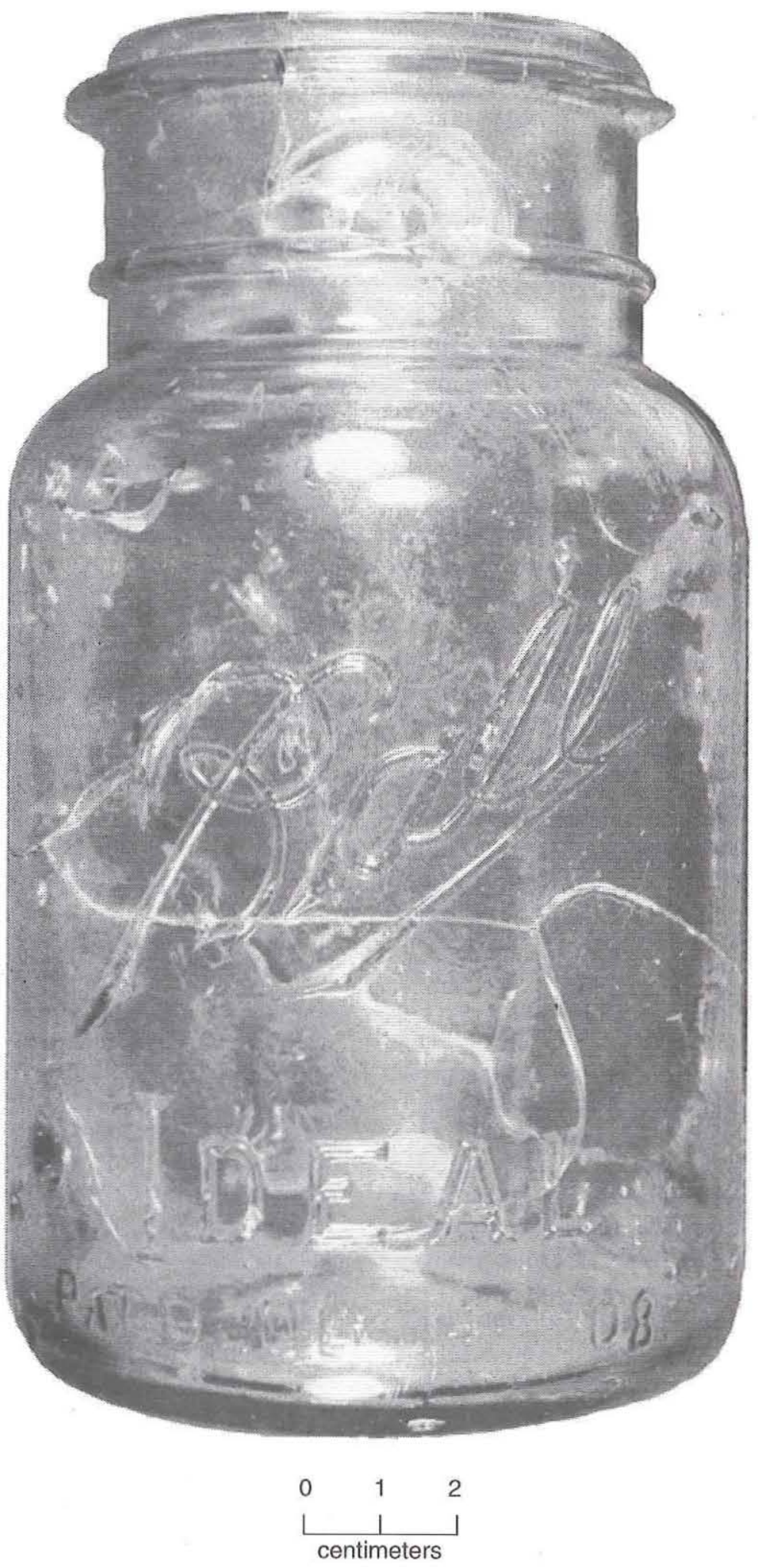

Figure 19. Ball Ideal jar showing half-round lug. 
1964) (Toulouse 1971). The other nine unidentified bottles were blown-in-mold and are probably late nineteenth or early twentieth century in date. None of these bottles have makers' marks.

All of the intact unidentifiable bottles recovered from Cistern II date to the twentieth century, one being firmly post-1929 and another post-1925, indicating that this feature was used during the time that Judge McDonald lived at Fanthorp.

\section{Pressed Glass}

Pressed (or press-molded) glass tablewares were common during the last half of the nineteenth century, but even as early as the 1820 s, items such as tumblers, cup plates, and salts were available (Jones and Sullivan 1989:34). Items here identifed as press molded include all sherds that have a pattern on the exterior of the vessel and a rounded interior that does not imitate the exterior pattern (see Jones and Sullivan [1989:33-35] for a detailed explanation of the pressmolding process). Some items (particularly tumblers) without an exterior pattern may also have been press molded, but they are not identified here as such because they could have been made by other methods. Originally, only lead glass was used to make these items, but after the discovery of lime glass in 1864 , this nonlead glass was utilized (Jones and Sullivan 1989:34). Crystal, or lead glass, continues to be used today for more-expensive tablewares as it has a more

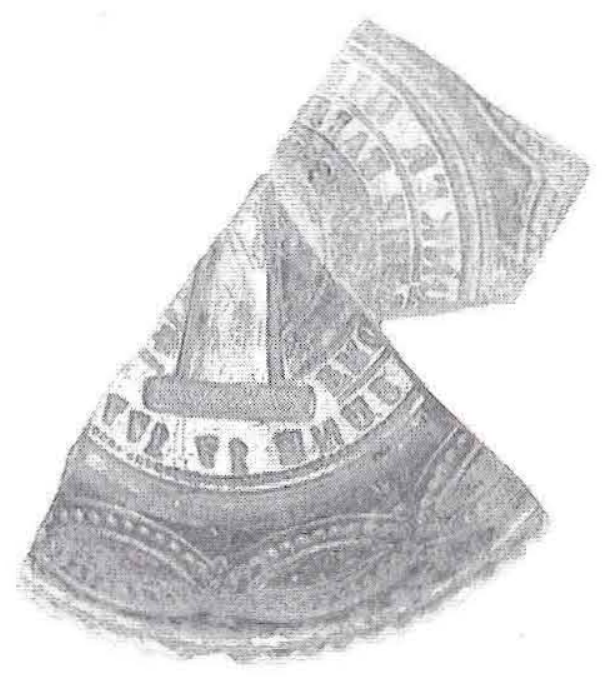

a
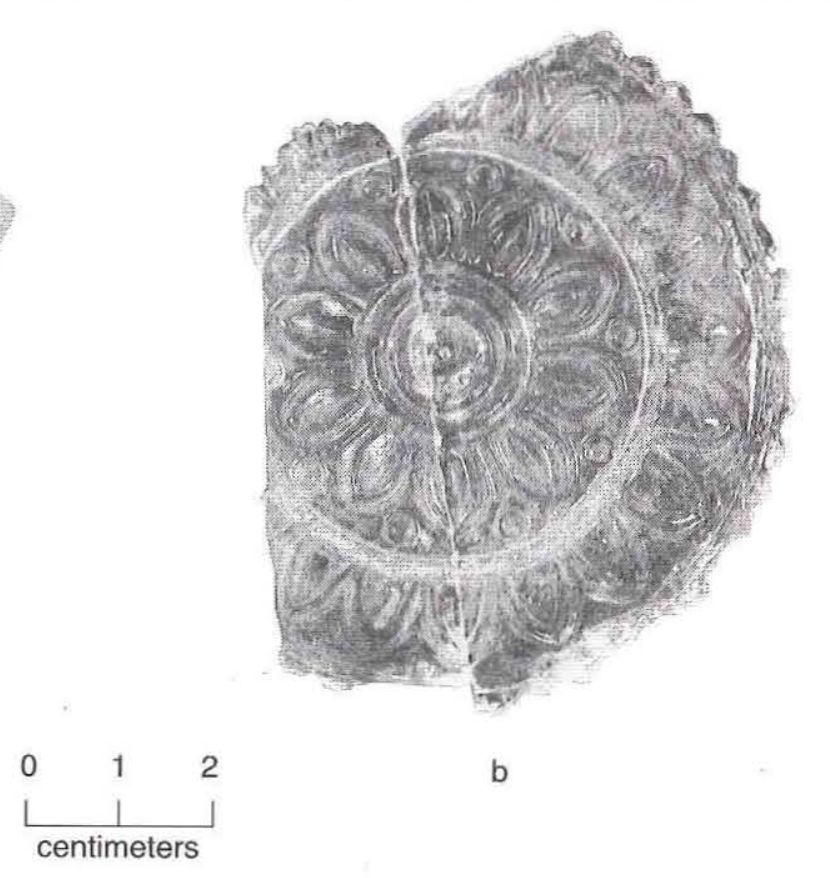
sherds, the bases of the plates appear to have read "FROM THE FAIR ... BRAVE /... UNKER pressed-glass commemorative cup plates were found (Figure 20a). The diameter of these plates is approximately $8.3 \mathrm{~cm}$. They commemorate the battle of
Bunker Hill and have embossed on their bases the mately $8.3 \mathrm{~cm}$. They commemorate the battle of
Bunker Hill and have embossed on their bases the Bunker Hill monument, which is located near Boston and was constructed ca. 1826 (McKearin and Wilson

refractive quality than the nonlead variety. One hundred four sherds of pressed glass containing lead were found at Fanthorp Inn.

The press-molded glass includes mostly fluted, paneled, or geometrically decorated pieces. In total, 392 sherds of pressed glass were identified: 6 bowl sherds, 15 cup plate sherds, 129 large hollowware sherds, and 82 other sherds. Of these 392 sherds, 48 pieces of pattern glass are diagnostic enough to include here. Twenty-six were chosen because they fluresce (or contain lead) and thus have the most chosen because of their distinct patterns. The other 344 pressed glass sherds are either too small to be identified or have generic patterns and therefore are

\section{Lead Glass}

Nine sherds of at least two (probably three)

(1)

Figure 20. Pressed glass. (a) Bunker Hill commemorative cup plate; (b) cup plate with floral pattern and scalloped rim. 
HIL . . . TT . . E FOUGHT/JUNE 17, 1775.” All of these sherds fluoresce under ultraviolet light, suggesting a high lead content. These cup plates most likely date between 1826 and 1870, and it is likely that they were used during the inn operation period.

A minimum of two other pressed cup plates are represented by six sherds. These have an embossed geometrical floral pattern and a scalloped rim (Figure $20 \mathrm{~b}$ ). These plates have a diameter of $7.6 \mathrm{~cm}$, and the sherds fluoresce under ultraviolet light. Two leadglass sherds are pressed with the feathers and bill of what looks like a swan or duck. These pieces crossmend and appear to be from a vessel with a handle, with the neck of the bird forming the handle. The vessel may have been a covered animal dish or a cup. Another vessel of unknown type is represented by four rim sherds (Figure 21a). The shape of the sherds and the thickness of the glass indicate that the vessel was quite large. One small pressed lead-glass sherd does not appear to be part of a vessel. It is a small disk approximately $2 \mathrm{~cm}$ in diameter and $0.5 \mathrm{~cm}$ thick with a star pressed into it. This artifact may have been inlaid into another material as a decoration. The last four lead glass sherds have unidentified patterns. One sherd looks like a knob or stopper fragment, another is an edge piece from a large vessel, and two are small sherds from unknown vessels.

\section{Nonlead Glass}

One large sherd of a pitcher was found. It is amethyst glass (1875-1914) with an unidentified pattern (Figure 21b). Six sherds from stemware vessels with the honeycomb design were found. At least one sherd is from a goblet, and the other five may represent the same vessel or others. One small sherd has a stippled leaf that matches exactly the "Gooseberry" pattern (Jenks et al. 1993:140). It may have been from the bowl of a wine glass. Eleven sherds of stemware bowls have the same unidentified pattern. Three sherds have a Daisy and Button with panel pattern. This piece is unidentified but has a scalloped edge.

\section{Other Tableware Glass}

Two sherds of an optically mold-blown, leadglass fluted cruet or caster were recovered. This is a six-sided vessel with ribbing, the bottom $4.5 \mathrm{~cm}$ being narrower than the top to create a ridge upon which the cruet rested in its stand. Both pieces fluoresce, and the base has a pontil scar. Use wear can be seen where the cruet and stand were in contact.

Eight cup, 5 lid, 72 stemware, 1 stopper, 61 tumbler, and 184 other sherds of nonpressed table- ware glass were recovered from the Fanthorp excavations. Of these, 272 are of nonlead glass, while 59 are of lead glass. None of these have makers' marks or very diagnostic patterns. The base of one nonlead tumbler does display a sand pontil mark.

\section{Lamp and Lamp Chimney Rim Sherds}

Two technologies are important in understanding lamp chimney chronologies. The first is the development of the lamp, the introduction of new burning materials, and the invention of the chimney. The second is the production of lamp chimneys and the composition of the glass of which they are made.

Lamps have been in use for hundreds of years. The introduction of the glass lamp chimney, however, did not occur until 1784 when Ami Argand patented a lamp with a chimney. This chimney created a draft that increased the brightness of the flame. Glass chimneys, therefore, can date to any time after 1784 (Woodhead et al. 1984:58). The original fuels burned in such lamps included primarily burning fluid (turpentine and alcohol mix) and whale oil, as well as other fuels such as lard and rapeseed and rosin oils (Thuro 1976:15-16). The shift to the use of kerosene or coal oil began after its patent in the mid-1850s. It was kerosene, an inexpensive derivative of petroleum, that made it possible for all households to be well lit during the dark evening hours and to extend their productive work time beyond daylight (Thuro 1976:15)

The refinement of soda production in 1863 combined with a new glass formula developed by William Leighton in 1864 changed the glass industry by providing a simpler, more effective, and less expensive process for making glass. The new Leighton formula produced a glass with refraction qualities approaching those of lead glass yet costing significantly less (Jones and Sullivan 1989:11). Nonlead lamp chimney glass, which does not fluoresce under an ultraviolet light, postdates 1864. It is not possible, however, to say that all fluorescing lamp chimney sherds predate 1864 as American lamp chimney manufacturers offered both lead and nonlead glass chimneys in the late nineteenth and early twentieth centuries (Woodhead et al. 1984:61).

A more reliable way to date lamp chimney sherds is through the rim decoration. Woodhead et al. (1984:62) state that decorated chimney tops became popular in the United States during the 1870s. This date is supported by the lamps illustrated in the Russell and Erwin catalogue of 1865 where none of the chimneys are decorated (Russell and Erwin 1865:417-428). A machine for crimping the edges 


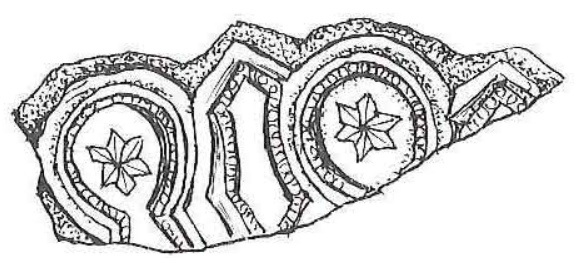

a

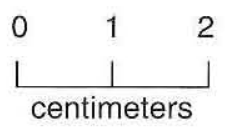

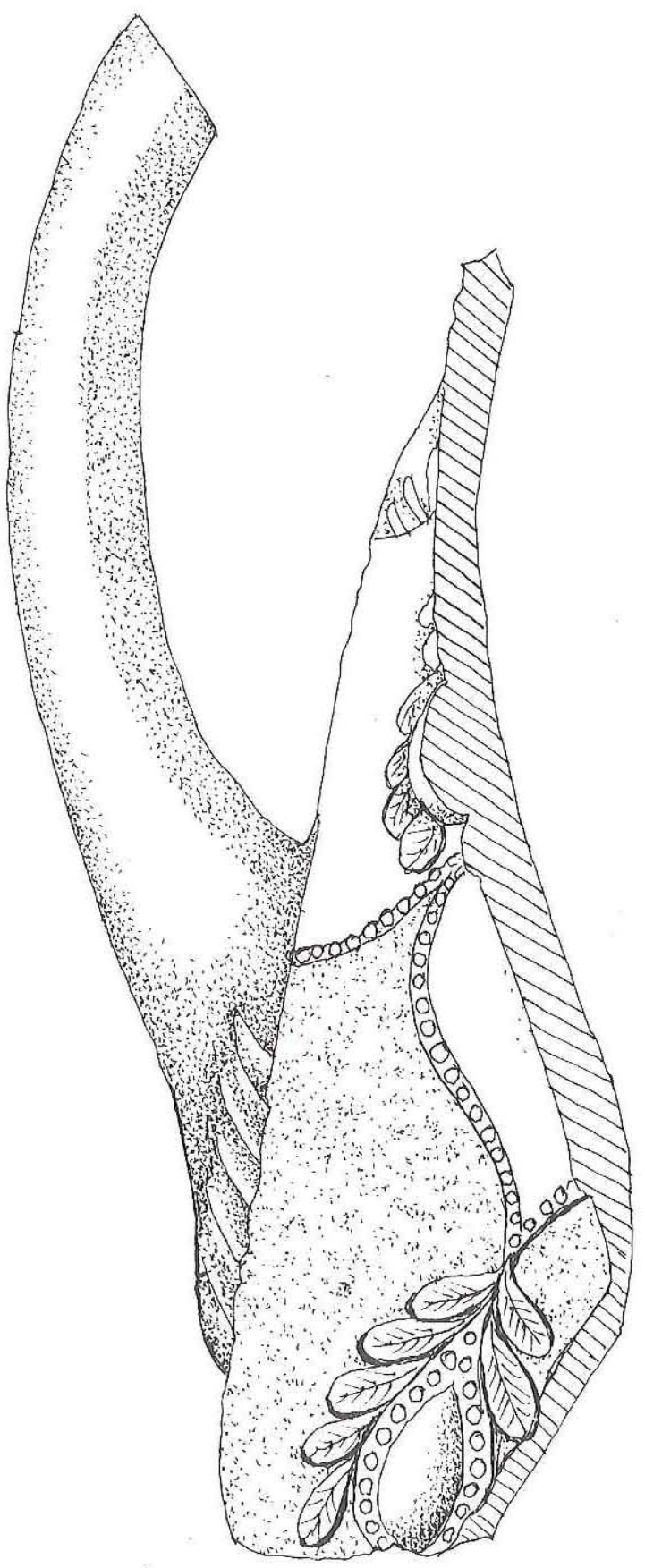

b

Figure 21. Pressed glass. (a) Rim from unidentified large pressed glass vessel; $(b)$ nonlead pressed glass pitcher. 
was patented in the United States in 1877, while one for creating beaded edges was patented in 1883 (Woodhead et al. 1984:62). It is difficult to tell a hand-crimped edge from one that is machine made, but at times this is possible. In general, crimped or beaded lamp chimneys were used alone rather than in conjunction with a globe (Woodhead et al. 1984:62).

For the Fanthorp collection, lamp chimney sherds were chosen for detailed analysis because of the many variations seen in the upper rim decorations. Only the decorated rim sherds (and one complete undecorated upper rim sherd) were separated for analysis. The primary reason for choosing only these pieces is because the undecorated body and rim sherds from lamp chimneys can easily be misidentified as tableware or bottle sherds. Also, the body sherds and undecorated rims (both upper and lower) are not particularly diagnostic for dating, especially when highly fragmented.

To determine if some correlation could be made between decoration type and glass composition, the sherds were separated into two groups: those that fluoresce and those that do not. Then these sherds were analyzed by decoration type-machine vs. hand made, crimped vs. beaded, etc. In total, 164 sherds of lamp chimney rims were analyzed in this manner. Of these, 109 do not fluoresce while 55 do. Two main styles of decoration are visible on the sherds - beaded and crimped-with crimped being most common on both kinds of glass and beaded being relatively frequent on nonlead glass (Table 4; Figure 22). Four other styles occur in much smaller numbers: basket weave, flat crimp, folded, and weave. Three styles are found only in the lead glass. These are basket weave, crimped with white edge, and folded. One style is seen only in the nonlead glass: flat crimped. The reason for these differences is most likely that those styles found only in the lead glass were fancy commodities made only of the more expensive material. The other alternative is that lamp chimneys were decorated earlier than previously expected (before the 1870s and before the development of soda glass) and that these styles are early examples of decorated chimney rims.

\section{Flaked Glass}

Four sherds of glass with purposefully flaked and shaped edges were found (Figure 23). All are from bottles and have at least one carefully flaked and

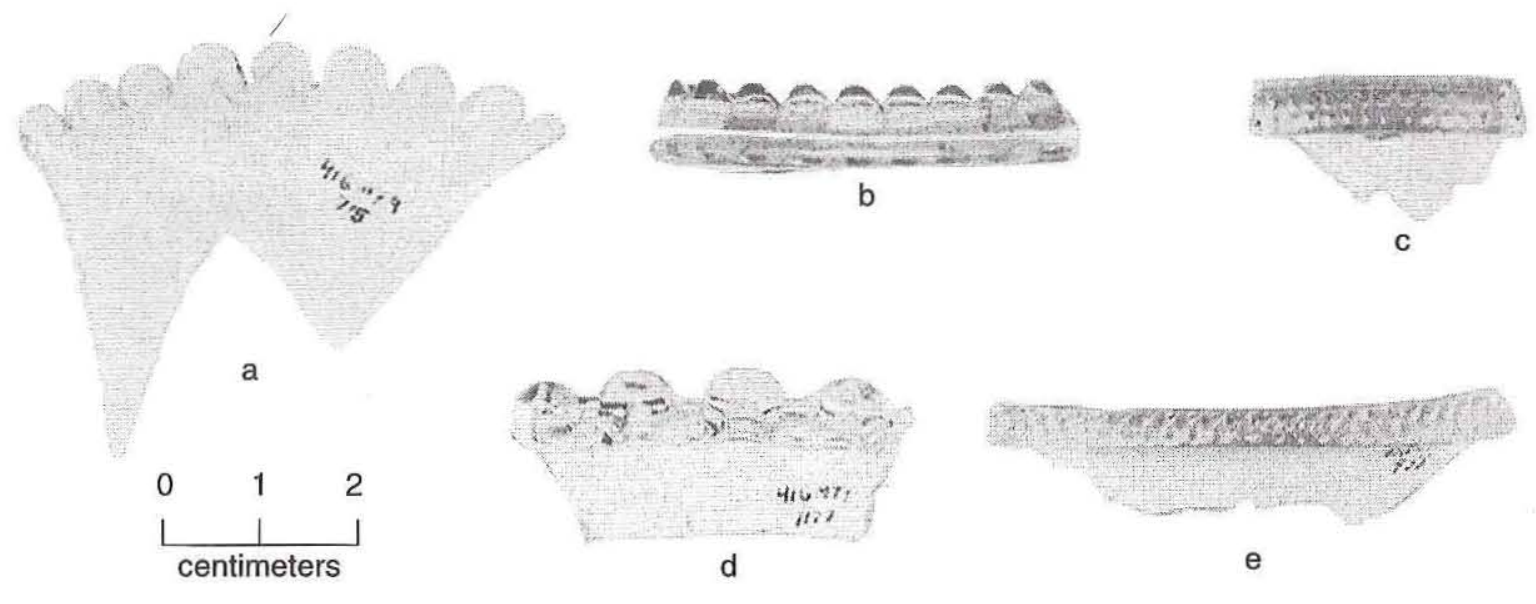

Figure 22. Lamp chimney glass rim decoration styles. (a) Crimped; $(b)$ beaded; $(c)$ basket weave; $(d)$ folded; $(e)$ weave (not illustrated is the flat crimp style, which has $1.5-\mathrm{cm}$-long flat-topped projections extending $0.2 \mathrm{~cm}$ above the rim at regular intervals). 

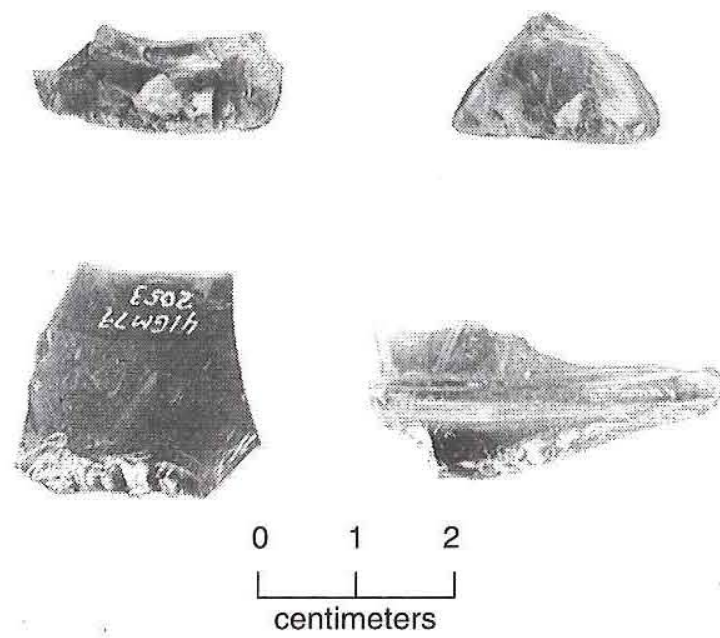

Figure 23. Flaked glass.

utilized edge. All four could have been used for scraping or for shaping wooden handles, etc. There is nothing particularly diagnostic about any of the glass sherds; one is from the body of an olive-colored bottle, and the other three are from colorless bottles. One colorless sherd is a bottle finish and appears to have broken away from the rest of the bottle after it was flaked as a tool, another is either from a finish or a neck, and the third is from the shoulder of a jar. While flaked glass has been found on other sites in contexts suggesting association with African Americans (Wilkie 1996), there is no evidence that this was the case at Fanthorp Inn.

\section{CERAMICS}

One of the most plentiful artifact types typically found on nineteenth-century sites is ceramics. Fanthorp is no exception, with 6,941 sherds of utilitarian/kitchen ceramics recovered during the 1983 and later seasons. An additional 101 sherds lack provenience information and therefore could be from any excavation season, including 1982; the sherds lacking provenience are not included in the totals presented here. These totals do not include ceramic doll parts, ceramic door knobs, clay pipes, marbles, or ceramic insulators, but they do include flower pots, utilitarian stoneware, kitchen earthenwares, and ceramic tablewares. All of these ceramic sherds were sorted based on paste and decoration type and were counted to provide a more detailed summary of the ceramics than given in Table 1 (Table 5).

Those ceramics chosen for more-detailed analysis are 295 sherds with identifiable transfer-print designs and 91 with makers' marks. The transfer-

Table 5. Utilitarian/Kitchen Ceramics

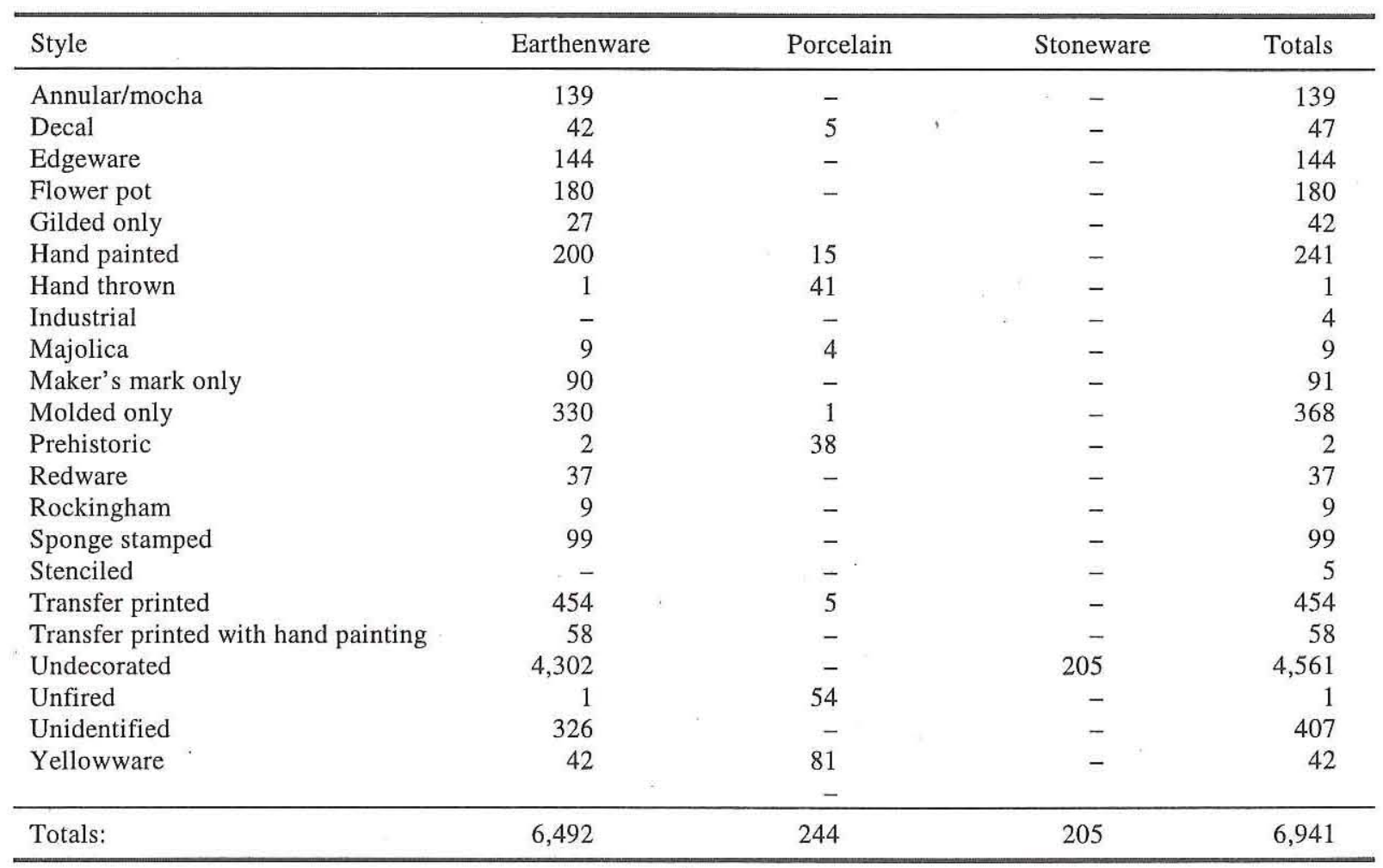


printed sherds were chosen because they show great variety, are well documented in the literature, are more easily assigned to maker than other decoration types, and are generally from the inn operation period (1830s$1860 \mathrm{~s})$. Sherds bearing makers' marks were chosen because of the information they can provide about country of origin, maker information, etc. Because most of the excavations occurred in high traffic areas, most of the sherds are too fragmented to allow estimation of a minimum vessel count or to accurately identify vessel types, but when vessels are identifiable they are noted.

\section{Transfer-Printed Ceramics}

Of the total 454 sherds of transfer-printed ceramics found at Fanthorp during the post-1982 field seasons, 272 belong to identified patterns and 23 belong to potentially identifiable patterns. A list of the 19 analyzed patterns is provided in Table 6 . Transferprint colors include black, blue, brown, green, purple, red, sepia, and turquoise. Two patterns are enameled overglaze with colors: one is sepia, the other is green. By far, though, blue transfer prints (305 sherds) are most common in this collection, with the various Blue Willow patterns dominating. Blue was the most common color to be used in transfer printing, but by ca. 1830 black, green, red, sepia, and yellow were used also (Coysh and Henrywood 1982; Majewski and O'Brien 1987).

When possible, a maker for each transfer-print

Table 6. Identified and Potentially Identifiable Transfer-Print Patterns

\begin{tabular}{|c|c|c|c|c|}
\hline Pattern Name & Color & $\begin{array}{l}\text { No. of } \\
\text { Sherds }\end{array}$ & Maker Information & Dates \\
\hline Agricultural Vase & red & 20 & $\begin{array}{l}\text { Possibly Ridgway, Morley, Wear \& Co., } \\
\text { Staffordshire }\end{array}$ & $1836-1842$ \\
\hline Belzoni & green & 3 & Enoch Wood \& Sons, Staffordshire & $1818-1846$ \\
\hline Blue Willow & blue & 52 & Various potters & \\
\hline Bologna & red & 3 & William Adams \& Sons, Staffordshire & $1830-1840$ \\
\hline Canova & $\begin{array}{l}\text { purple } \\
\text { blue }\end{array}$ & $\begin{array}{l}13 \\
10\end{array}$ & Thomas Mayer or G. Phillips, Staffordshire & $\begin{array}{l}\text { ca. } 1826-1845 \\
\text { or } 1834-1848\end{array}$ \\
\hline Chinese Pastime & purple & 11 & Davenport, Staffordshire & $1820-1860$ \\
\hline Columbia & blue & 6 & William Adams \& Sons, Staffordshire & ca. 1850 \\
\hline Etruria & sepia & 25 & Challinor \& Mayer , & post-1891 \\
\hline Forest & blue & 30 & $\begin{array}{l}\text { J. Clementson, or Samuel Alcock \& Co., } \\
\text { Staffordshire, or John Allason, Durham }\end{array}$ & $\begin{array}{l}1839-1864 \text { or } \\
1838-1841 \text { or } \\
1830-1859\end{array}$ \\
\hline Hannibal Passing the Alps & red & 1 & Knight, Elkin \& Co., Staffordshire & $1826-1846$ \\
\hline Millenium & purple & 14 & Ralph Stevenson \& Son, Staffordshire & $1832-1835$ \\
\hline Pagoda & red & 18 & Enoch Wood \& Sons, Staffordshire & ca. $1818-1846$ \\
\hline Ruins & red & 2 & William Adams \& Co., Staffordshire & $1800-1864$ \\
\hline Sirius & blue & 20 & James \& Thomas Edwards, Staffordshire & $1839-1841$ \\
\hline Sitka & brown & 27 & T. Hughes, Staffordshire & $1860-1894$ \\
\hline Texian Campaign & blue & 17 & $\begin{array}{l}\text { Anthony Shaw, Staffordshire, or J. \& M. P. } \\
\text { Bell \& Co., Glasgow }\end{array}$ & $\begin{array}{l}1851-1882 \text { or } \\
\text { ca. } 1850 \\
(1842-1928)\end{array}$ \\
\hline Unidentified "beehive" & blue & 1 & unknown & unknown \\
\hline Unidentified "oakleaf" & blue & 12 & David Johnston, Bordeaux, France & $1830-1844$ \\
\hline Unidentified drapery & blue & 10 & unknown & unknown \\
\hline Total: & & 295 & & \\
\hline
\end{tabular}


pattern is identified here, but it must be noted that prior to the 1842 copyright restrictions, it was not always possible to ensure that only one maker was producing a certain pattern (Coysh and Henrywood 1982:10). Therefore, although the makers tried to prevent their patterns from being copied, on those pieces with no maker's mark it is possible that more than one maker could have produced it. Of the 16 patterns identified to possible maker, 12 are from Staffordshire District, England, potteries and two others were most likely made in the Staffordshire area. One pattern is from the Bordeaux region of France. It is not surprising that the majority of these patterns were sourced to England since "... the British dominated the ceramic market until the late 1800s" (Majewski and O'Brien 1987:98).

Most of the identified transfer-print patterns date to the inn operation period (1830s to 1860 s). Two notable exceptions can be seen. The first, made by $T$. Hughes, a potter in operation in Burslem, England, from 1860 to 1894 , is the brown print named "Sitka" (Figure 24). The company became Thomas Hughes \& Son in 1895 (Godden 1991:339). This pattern was not found in the literature but was identified from its name on the sherds. The other pattern that is believed to date to the late nineteenth or early twentieth century is "Etruria" by Challinor and Mayer (Figure 25). This is a sepia transfer print with red, yellow, and green handpainting filling in the print under the glaze. The inclusion of "England" in the maker's mark indicates a post-1891 date (Godden 1991:11) despite the belief by some researchers that revival transfer designs were rarely enhanced by handpainted detail (Henry and Garrow 1982:468 in Majewski and O'Brien 1987:145). The names Challinor and Mayer are identified as separate potters by Godden (1991), but he does not record them as having worked together.

Twenty sherds of a red-printed refined earthenware with a border pattern identical to that on "Agricultural Vase" were recovered. This border consists of a dendritic pattern interspersed with stylized, four-petaled flowers (Figure 26). No sherds from the central pattern were identified. This pattern is known to have been made by Ridgway, Morley, Wear \& Co., who were in business in Hanley, Staffordshire, from 1836 to 1842 (Godden 1991:535; Williams 1978:57). Pieces from a cup were found, as were some from either a saucer or plate.

Three sherds of the pattern "Belzoni" were recovered (Figure 27). This pattern is printed in green and is known to have been produced by Enoch Wood \& Sons who were in operation between 1818 and 1846 in Burslem, Staffordshire (Coysh and Henry- wood 1982:40; Godden 1991:685; Williams 1978:98). At least one lid fragment is present, along with one sherd that appears to be from a footed vessel.

None of the 52 sherds of "Blue Willow" can be associated with a maker (no marks were associated with sherds recovered in earlier seasons either). Many makers produced, and still reproduce, this pattern. The first Willow pattern was designed by Thomas Minton in 1780, and a standard Willow pattern was produced by the first decade of the nineteenth century (Coysh and Henrywood 1982:402; Majewski and O'Brien 1987:142). At least two different patterns are in the Fanthorp collection. Differences can be seen not only in slight modifications to the central scene, but also in the edge pattern where one variation consists of repeated adjacent circles with a dot in the center of each while the other is made up of repeated squares with dots in their centers.

Three sherds of the "Bologna" pattern were recovered. This is a red pattern made by William Adams \& Sons of Stoke-on-Trent, Staffordshire, between 1830 and 1840 (Coysh and Henrywood 1982:16; Godden 1991:21; Williams 1978:201).

The "Canova" pattern, made by either Thomas Mayer (1826-1835) or G. Phillips (1834-1848) (Coysh and Henrywood 1982:69; Williams 1978: 214), was found on 23 sherds (Coysh and Henrywood also list J. \& M. P. Bell \& Co. and David Methven \& Sons as having made patterns with the name Canova, but it is not clear whether these are identical patterns). Both Mayer and Phillips operated potteries out of Staffordshire. This pattern occurs in both blue and purple. The 13 purple sherds are generally from unidentifiable vessels, although 1 appears to be from a pitcher and another is probably the rim of a cup. None of the 10 blue sherds are identifiable to vessel type.

Eleven sherds of the "Chinese Pastime" pattern in purple are present. This pattern was made by the Staffordshire Davenport pottery and is dated in Williams (1978:115) between 1820 and 1860. Pollan et al. (1996:28) date Chinese Pastime patterns from Old Velasco in Brazoria County between 1834 and 1866 . Only a small part of a cartouche was found, and most of the sherds appear to be from plates.

A blue transfer print made by William Adams and Sons of Stoke-on-Trent, Staffordshire, called "Columbia" was identified. Five sherds from the border pattern and one sherd with a small fragment of the central pattern are present. This pattern has been dated to ca. 1850 (Williams and Weber 1986:237). All of these sherds are likely from plates.

The "Etruria" pattern mentioned previously is found on 25 sherds (see Figure 25). This floral sepia 


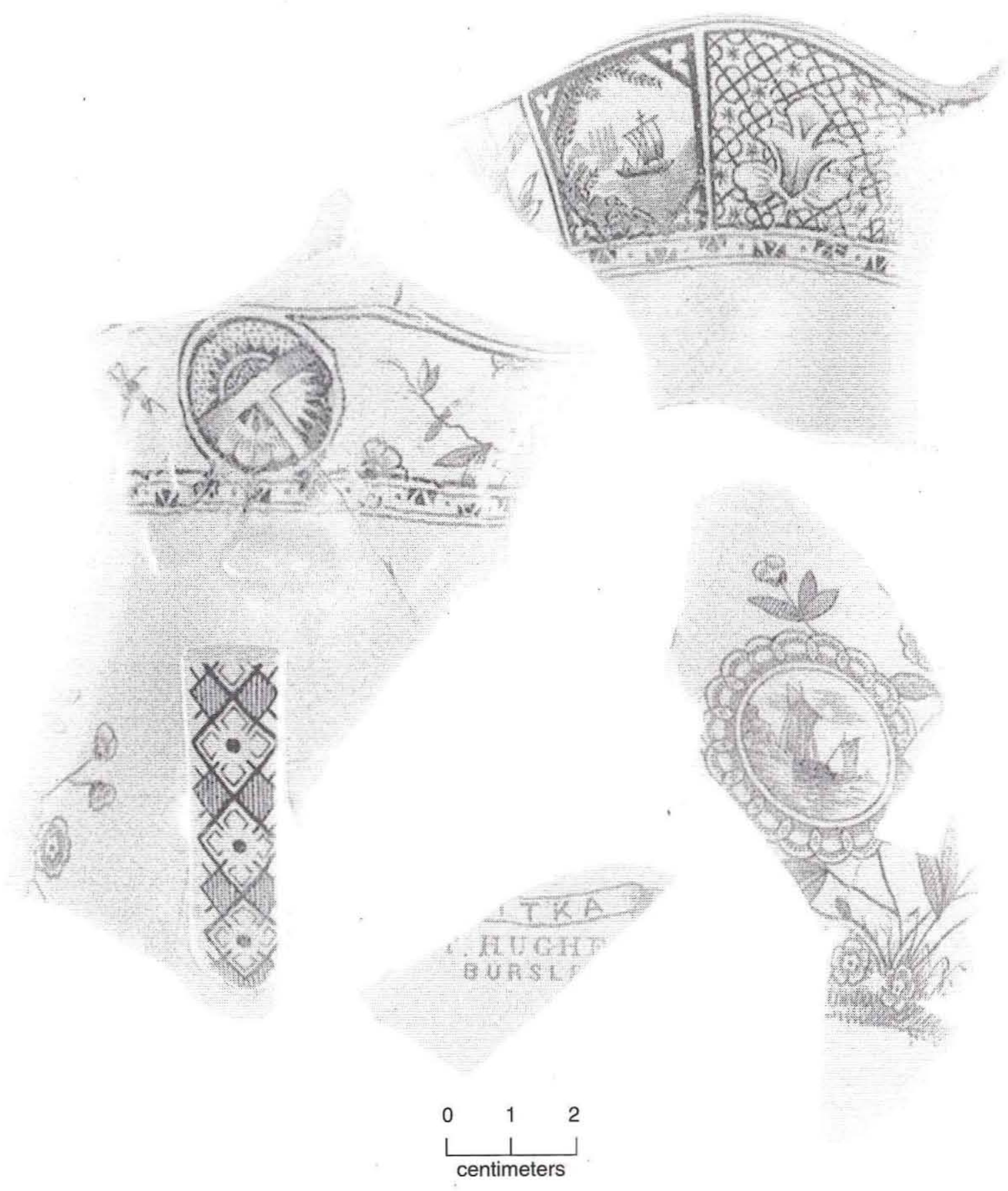

Figure 24. "Sitka" by T. Hughes (some of the cross-mended sherds are from the 1982 excavations). 

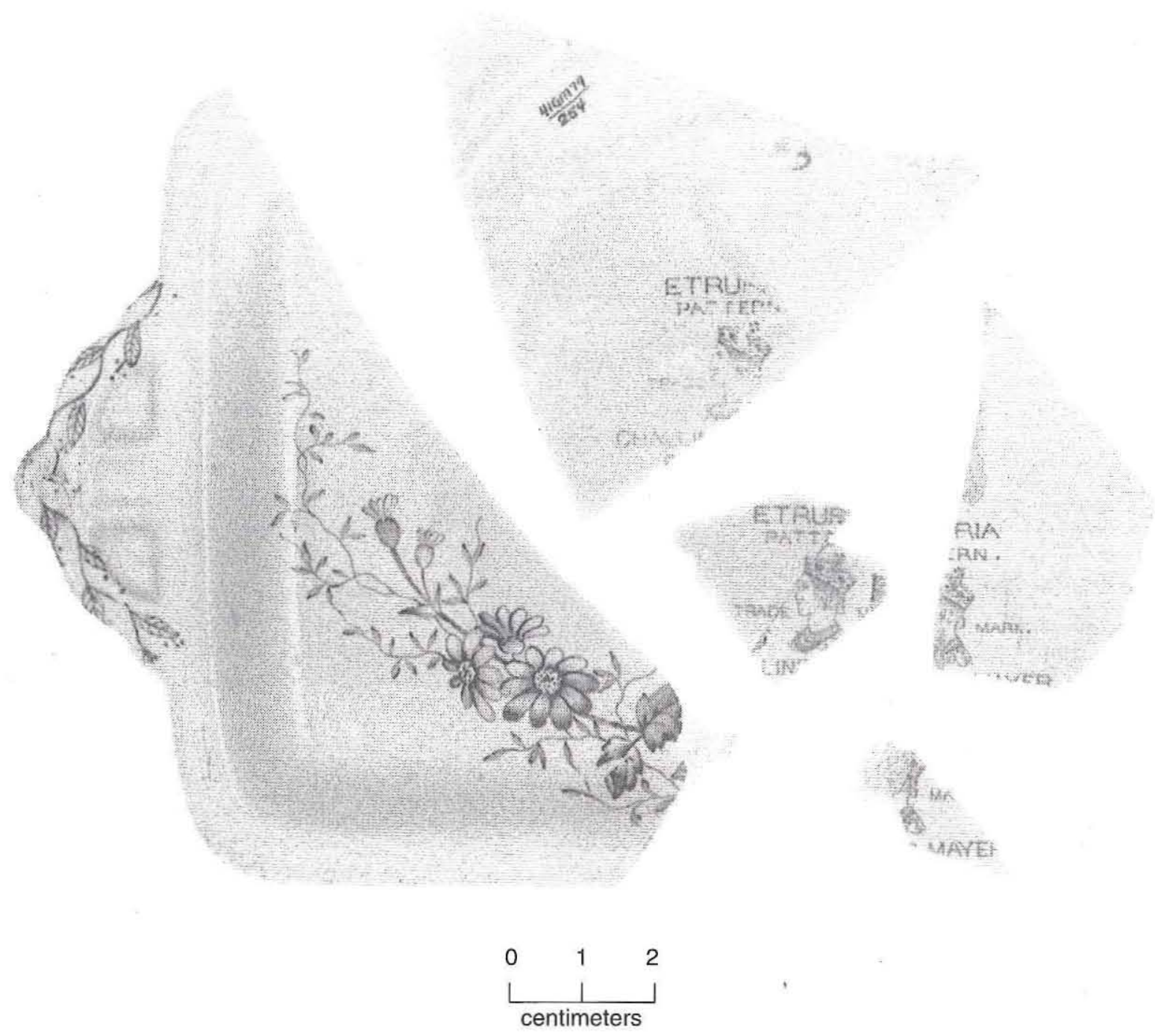

Figure 25. "Etruria" by Challinor and Mayer (some of the sherds were excavated in 1982).

transfer print was delicately handpainted under the glaze with green leaves and red and yellow flowers. Several makers' marks were trade marked by Challinor and Mayer of England. Coysh and Henrywood provide some information about Etruria:

The famous Wedgwood factory at Etruria, near Burslem, was started in 1769 on the Ridgehouse Estate. Josiah Wedgwood himself built a house called Etruria Hall nearby using Joseph Pickwood as architect. The Hall was eventually sold in 1844 but the factory continued in use until 1949 , when new works at Barlaston were completed. The name Etruria can be found as part of many of the later Wedgwood marks. It was originally an area in central Italy, the home of the Etruscans [Coysh and Henrywood 1982:130].

This Etruria pattern was not made by Wedgwood, but Challinor and Mayer may have chosen this particular title for the pattern to use an established name. The vessels represented include what looks like a butter dish, a large serving platter, a smaller serving dish, a strainer, and a plate. The pre-1983 excavations yielded a cup, saucer, plate, and serving dishes. This pattern is represented by some of the largest transferprinted ceramic sherds at the site, as well as the widest variety of vessel types. As mentioned earlier, the inclusion of "England" in the mark indicates a post1891 date for this pattern as this was required for 

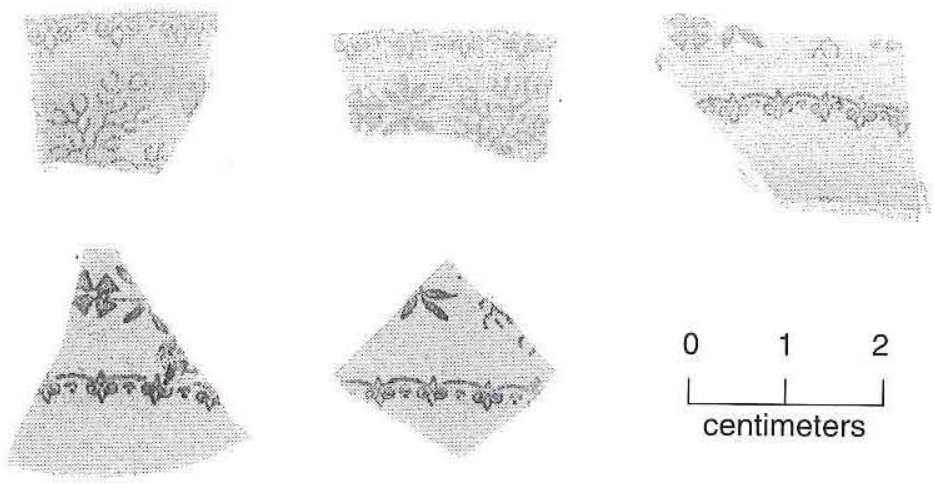

Figure 26. "Agricultural Vase" by Ridgway, Morley, Wear \& Co.
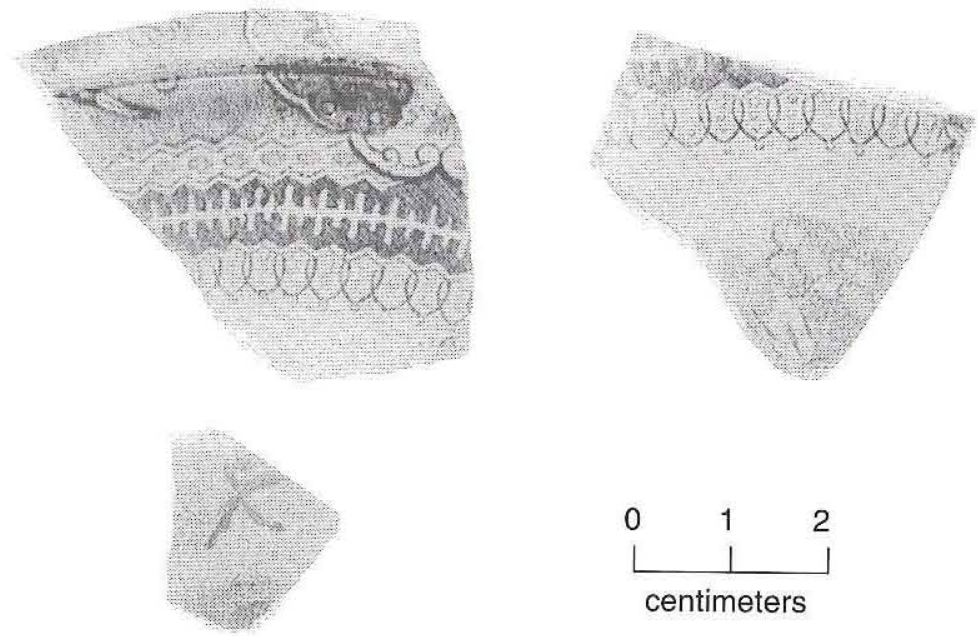

Figure 27. "Belzoni" by Enoch Wood \& Sons (the largest sherd is from the 1982 excavations).

American imports by the McKinley Tariff Act which was passed in that year (Godden 1991:11).

One pattern known as "Forest" is present on 30 sherds. This pattern was a popular one and is known to have been made by J. Clementson (1839-1864), John Allason (1838-1841), and Samuel Alcock \& Co. (1830-1859) (Godden 1991; Pollan et al. 1996:124; Williams 1978:630; Williams and Weber 1986:360, 662). At least 16 sherds appear to be cup sherds showing a scalloped rim, while the rest are likely plate or saucer sherds.

One sherd identified as "Hannibal Passing the Alps" was recovered (Figure 28). This is a red print on a cup. The portion of the pattern present shows the rear end of a horse and what appear to be three men tending a field. Illustrations can be found in Coysh and Henrywood (1982:170) and Williams and Weber (1986:283-285). This pattern was made by Knight, Elkin \& Co., a Fenton, Staffordshire, company, from ca. 1826 to 1846 and has been found in blue, red, and sepia (Williams and Weber 1986:283).

Fourteen sherds of the "Millenium" pattern in purple print were recovered. Millenium is known to have been made by Ralph Stevenson \& Son who were in operation in Cobridge, Staffordshire, from 1832 to 1835 (Godden 1991:597; Williams 1978:645). All of the Fanthorp sherds appear to be from dinner or soup plates.

Eighteen sherds of a red version of "Pagoda". were excavated (Figure 29). Most can be identified as plate sherds; the rest cannot be identified to vessel type. This pattern is known to have been made by Enoch Wood \& Sons of Burslem, Staffordshire, and dates ca. 1818-1846 (Williams 1978: $760-761$ ). Part of the cartouche is seen on one sherd with ". . . oda" visible.

The scenic cartouche found on the border pattern of a saucer pictured in Williams (1978:398) is the same scene as that found on a flat sherd from Fanthorp. The pattern is "Ruins" by William Adams \& Co. of Stoke-on-Trent from ca. 1800 to 1864. The print is red and shows a man with a stick or shovel standing in front of some ruins (Figure 30). A cup rim sherd with a border very similar to that of the "Ruins" piece was also recovered in the same color.
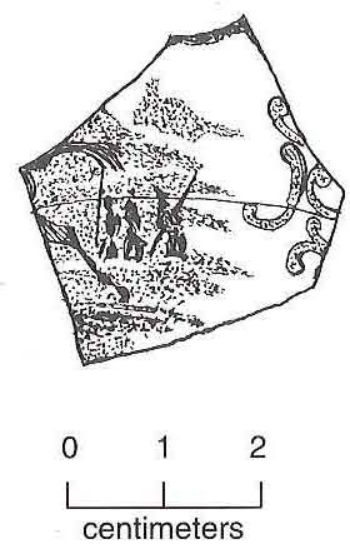

Figure 28. "Hannibal Passing the Alps" by Knight, Elkin \& Co. 


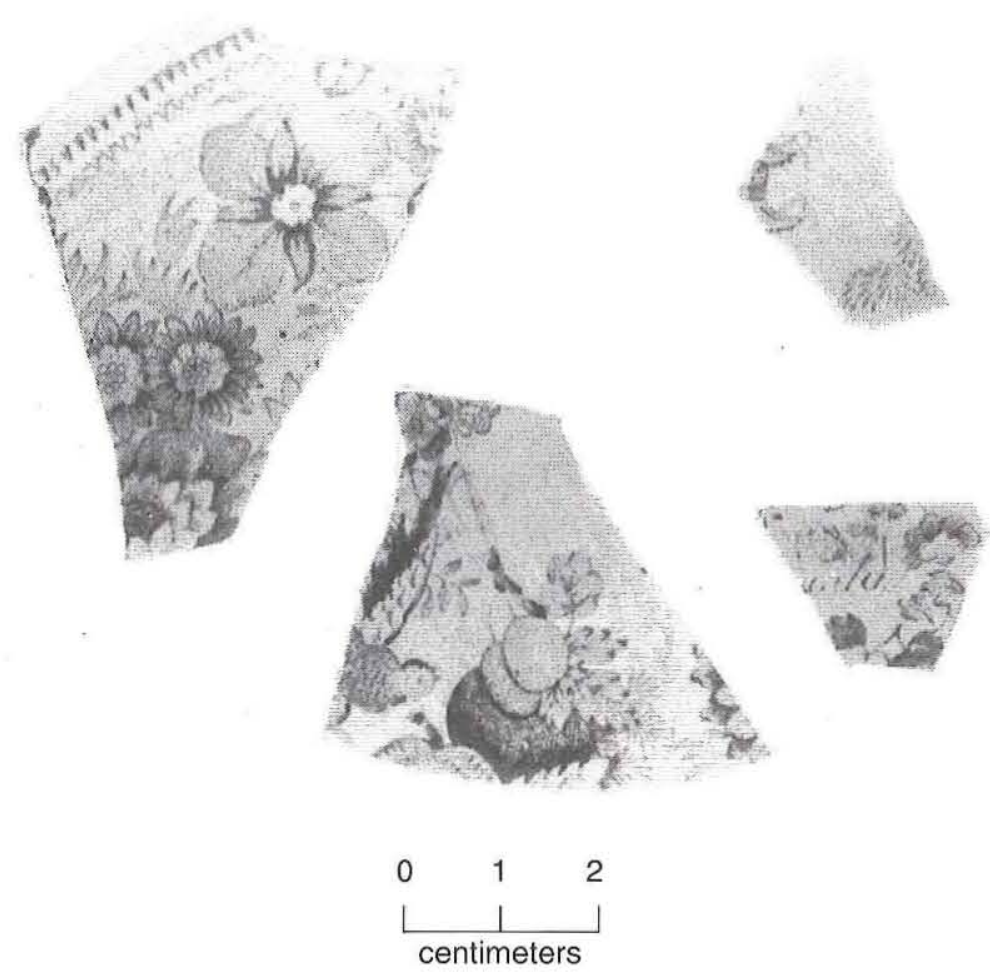

Figure 29. "Pagoda" by Enoch Wood \& Sons.

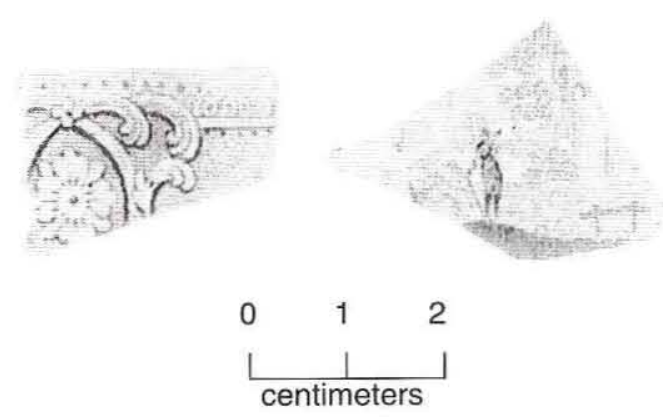

Figure 30. "Ruins" by William Adams \& Co.

Twenty sherds of a blue print called "Sirius" are present. The border pattern represented on these pieces has a sprig background with six-petaled flowers evenly spaced throughout (Figure 31). Although there are central patterns illustrated in Williams (1978:165), the largest sherd in this collection does not seem to have one. This large sherd is from a $17.8-\mathrm{cm}$-diameter plate or saucer, two others are from a lid, and the rest are too small for vessel type to be identified. Sirius is known to have been made by James and Thomas Edwards of Burslem, Staffordshire, from 1839 to 1841 (Williams 1978:165).

The 27 sherds mentioned previously with the brown-print "Sitka" pattern represent at least three large hollowware vessels (see Figure 24). One of these was a large pitcher, it is likely that the second was a smaller pitcher, and sherds from a large bowl are also present. All of these sherds may have belonged to one toilet set. The mark found on one of the sherds identifies the pattern name and T. Hughes of Burslem, Staffordshire, as the potter. Thomas Hughes was in business in Burslem from 1860 to 1894 and subsequently became Thomas Hughes \& Son (Godden 1991:339). Although the mark is not complete, from its layout it is not likely that it was T. Hughes and Son. The pattern is complex and includes a floral component, medallions, and sailing ships as well as geometrical designs.

"Texian Campaign," a blue transfer print made by either Anthony Shaw of Staffordshire or J. \& M. P. Bell \& Co. of Glasgow, Scotland, is found on 17 sherds. The date given in Williams for this pattern is ca. 1850 , but the date range for Anthony Shaw is 1851 to ca. 1900 (Godden 1991:571; Williams 1978:528). The mark in Williams

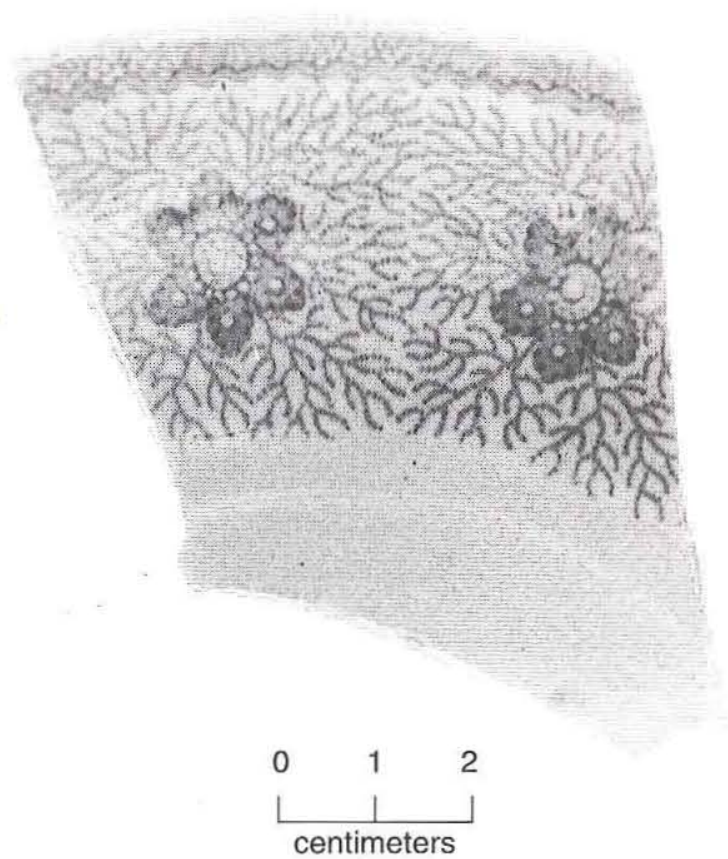

Figure 31. "Sirius" by James and Thomas Edwards. 
that associates this pattern with J. \& M. P. Bell places it between 1842 and 1860 (Godden 1991:66; Williams 1978:528). Only plate sherds of this pattern are present.

Twelve sherds of one blue transfer print were found. This pattern has no known name, but the maker was David Johnston of Bordeaux, France (Tardy 1979:200-201) (Figure 32). This is a sheet pattern with seven-petaled flowers and sprigs in between. The petals on the flowers have a distinct oak leaf shape. All of the sherds appear to be plates.

Ten border sherds of one blue transfer-print pattern were recovered. This pattern, which incorporates flowers and draped fabric, is very similar to the border on a pattern called "Eastern Scenery II," but it is not identical. The maker and date are unknown.

One other unidentified pattern represented by one sherd and also present in the pre-1983 collection is included. All sherds show beehives in a blue transfer print, but none of the beehives matches the styles of illustrated prints in the references. The maker, therefore, remains unknown as do the dates of production. Only cup fragments are present.

\section{Nontransfer-Print Ceramic Marks}

Ninety-five nontransfer-print sherds have 82 makers' marks, with 32 sherds representing 26 marks identifiable to maker and 24 sherds having 21 marks that are potentially identifiable. The remaining 39 sherds consist of 12 with black printed royal arms marks, 1 sherd with a black printed shield, 1 sherd with a green printed crown, and 25 sherds with unidentifiable portions of marks. Because they are nondiagnostic, these last 39 sherds are not discussed further here.

One extremely small earthenware fragment has an impressed Davenport anchor mark. The impressed anchor is similar to those used by Davenport after 1795 , and the accompanying lettering appears to be all uppercase, a quality seen after 1805 . The company was in business until 1887 (Godden 1991:189). A larger sherd with the impressed Davenport anchor mark was also recovered. More of the mark remains on this piece, and it can be more tightly dated to $1805-1860$ as it has all uppercase letters and numbers on either side of the anchor shaft. These numbers are not legible. All of the remaining datable marks are from the last half of the nineteenth century into the first half of the twentieth century.

Three marks from the Edward Clarke pottery in Tunstall, England, were found (Figure 33a). Edward Clarke was in business at the Phoenix Works in Tunstall from 1865 to 1877 , and then at the Churchyard Works in Burslem from 1878 to 1887 . The marks found at Fanthorp are royal arms marks with the lion
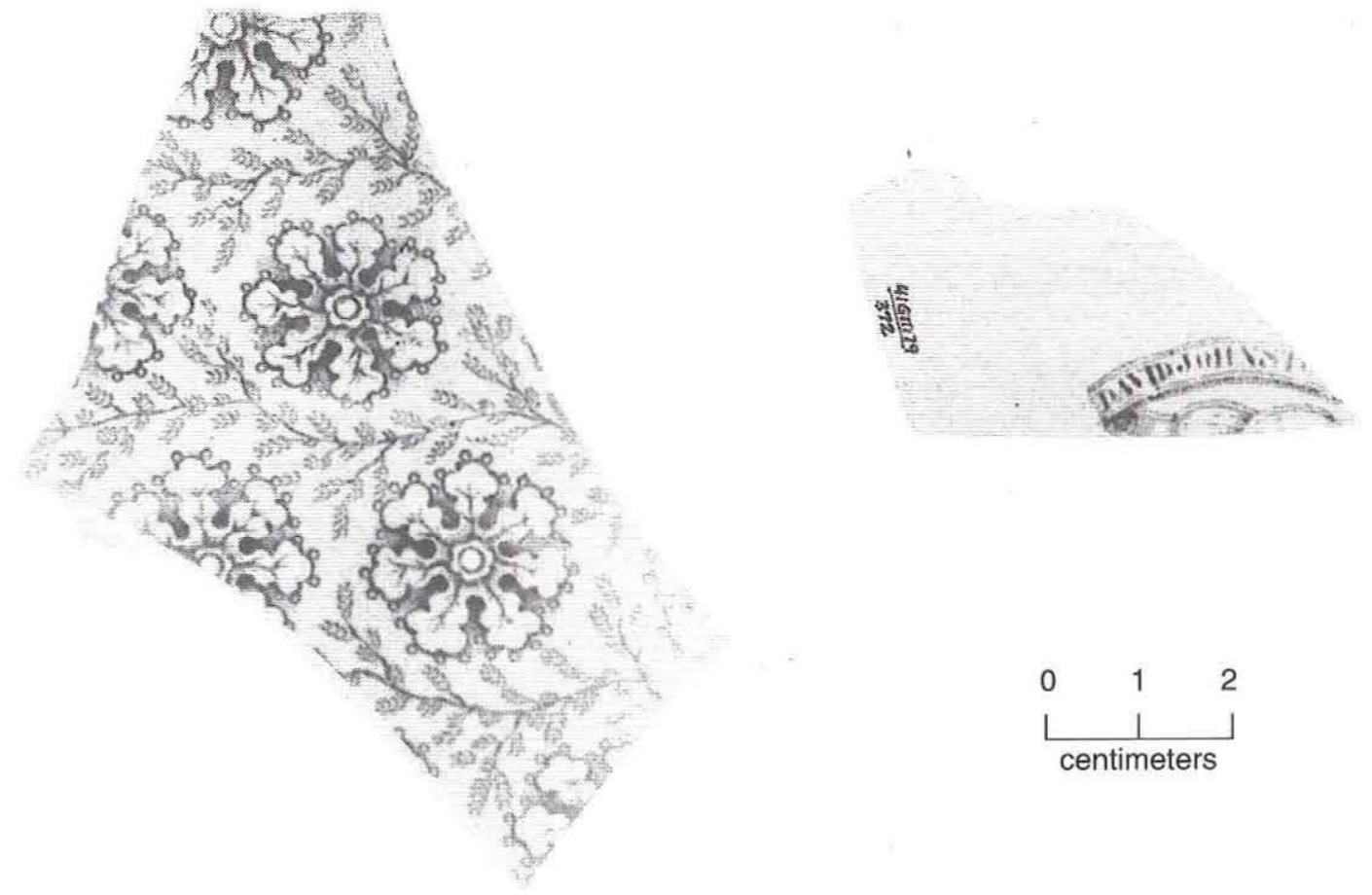

Figure 32. Oak leaf pattern by David Johnston of Bordeaux, France.

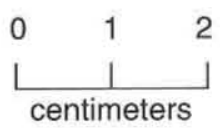




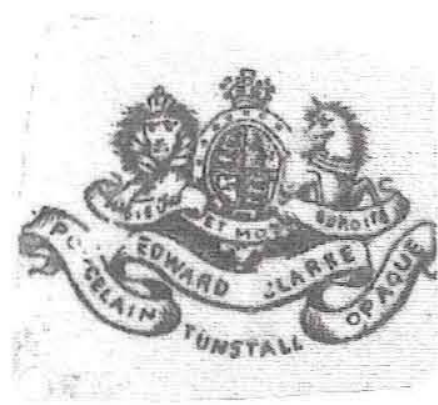

a

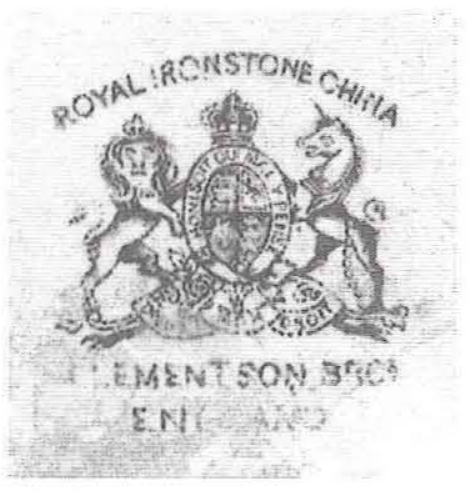

b

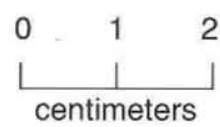

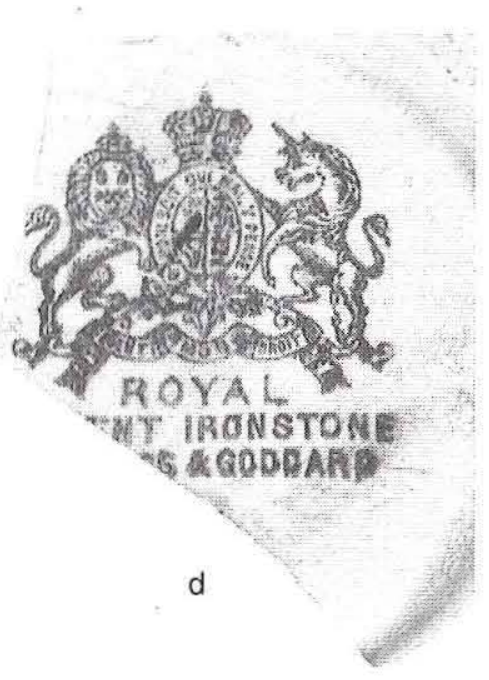

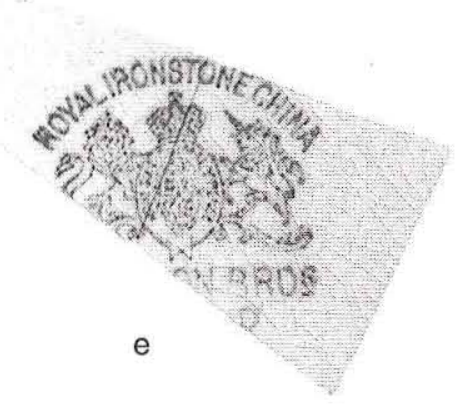

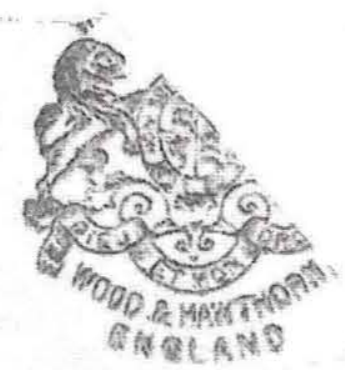

C

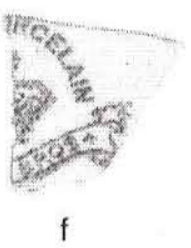

Figure 33. Makers' marks. (a) Edward Clarke; $(b)$ Clementson Bros.; (c) Wood \& Hawthorne; (d) Burgess and Goddard; (e) Johnson Brothers royal arms; $(f)$ Johnson Brothers crown.

on the left and the unicorn on the right. In a ribbon under the animals is printed "DIEU ET MON DROIT." In another ribbon under the first is printed "EDWARD CLARKE/PORCELAIN OPAQUE," and under all of this is "TUNSTALL." The Tunstall address was used from 1865 to 1877 (Godden 1991:147).

Of the same vintage is a mark from Clementson Brothers of the Phoenix Works and Bell Works, Hanley, Staffordshire (Figure 33b). This royal arms mark was produced between 1867 and 1880 (Godden 1991:149). A Wood and Hawthorne mark (Figure $33 c$ ) is also a royal arms mark and dates from 1882 to 1887. Wood and Hawthorne produced earthenwares out of the Abbey Pottery in Cobridge, Staffordshire. Two royal arms marks (Figure 33d) appear to be from Burgess and Goddard, a pottery from Longton ca. 1870 (Wetherbee 1985:21). Both marks are partial, one with "ROYAL/... ENT IRONSTONE/... S \& GODDARD" and the other with "... IRONSTONE/. . . RGESS \& GODDARD.” Another mark is printed with a royal arms mark which reads "IRONSTONE CHI.......RGESS, BUR ...," possibly made by Henry Burgess of Burslem, Staffordshire, in business from 1864 to 1892 (Godden 1991:116).

Two royal arms marks from Johnson Brothers of Hanley, Staffordshire, date 1883 to 1913 (Figure 33e). Two crown marks from Johnson Brothers also were found. These are printed in brown and postdate 1900 (Figure 33f). The royal arms marks were found on "Royal Ironstone China," and the crown marks were used on "Royal Semi-Porcelain" (Godden 1991:355).

An impressed James Edwards and Son mark was also recovered. The mark has "JAS. EDWARDS AND SON/DALEHALL" impressed. James Edwards and 
Son were in production between 1851 and 1882 at Dale Hall, Burslem, Staffordshire (Godden 1991:230). One mark on refined earthenware is printed in sepia and has the name "W. \& E. CORN" (Figure 34a). This Staffordshire pottery was in business from 1864 until 1904, but most of the pre-1900 wares are unmarked, giving this sherd a date of 1900-1904 (Godden 1991:175).

The shadow of one fugitive decaled mark is from the Ridgways pottery in Hanley, Staffordshire. This mark has a bow and quiver with the words "HERRING BONE/ENGLAND/RIDGWAYS." This mark dates 1912 to 1920 (Godden 1991:539). A British mark from Powell \& Bishop is printed in black (Figure 34b). This was a Hanley, Staffordshire, pottery in operation from 1876 to 1878 , formerly Livesley Powell \& Co., and subsequently Powell, Bishop \& Stonier (Godden 1991:509).

Eight marks are from American potteries. Two sherds of black-printed marks have portions of the English shield on them. One has an "... A" to the far right under the shield (Figure 34c). These could be part of a common mark combining both the American and English shield and used by both English and American potters in the late nineteenth century. One of these marks shows scrolling to the upper right and leaves to the lower right of the shield, closely resembling the mark used by John Wyllie \& Son of East Liverpool, Ohio, from 1880 to ca. 1892 (DeBolt 1988:79-80; Kovel and Kovel 1986:268).

A Homer Laughlin mark with a black-printed eagle over an inverted lion over the text "PREMIUM STONE CHINA/HOMER LAUGHLIN" (Figure 34d) was found. Homer Laughlin was a potter from the East Liverpool district of Ohio, and his company is still in production. This mark dates from 1877 to ca. 1900 (Gates and Ormerod 1982:131). Another mark, found on four cross-mending sherds (three of which are from the pre-1983 excavations), is from the Knowles, Taylor and Knowles pottery also located in the East Liverpool, Ohio, area. This green-printed mark shows a bird in a circle with scrollwork above and "SEMI-VITREOUS PORCELAIN" encircling this circle, and "K. T. \& K. C. . / 214 ..." below and dates 1900 to ca. 1920. A second green-printed Knowles, Taylor and Knowles sherd only has the text "K. . ./S-. . ./CH . . ./25" and dates ca. 1905 to 1929 (Gates and Ormerod 1982:126). One green-printed mark on a decal-decorated vessel is from Crown Potteries Co. of Evansville, Indiana (DeBolt 1988:25;

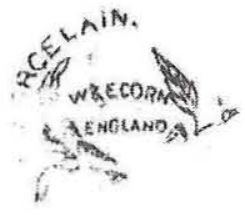

a

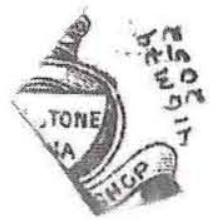

b
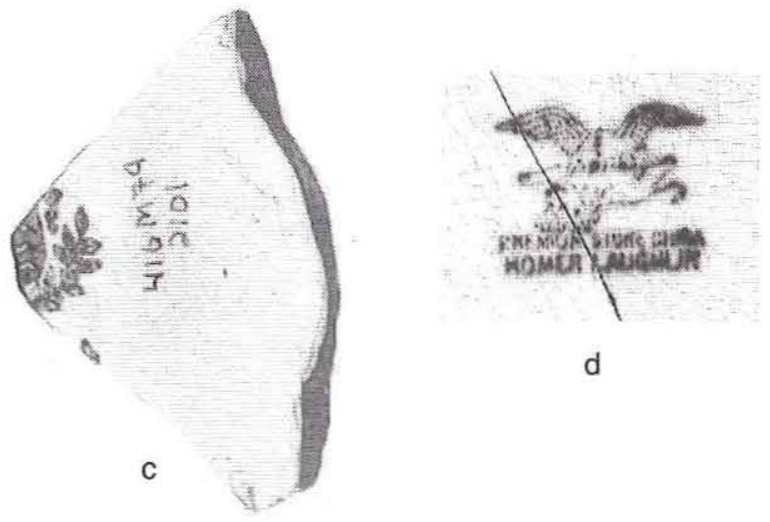

d

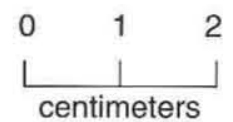

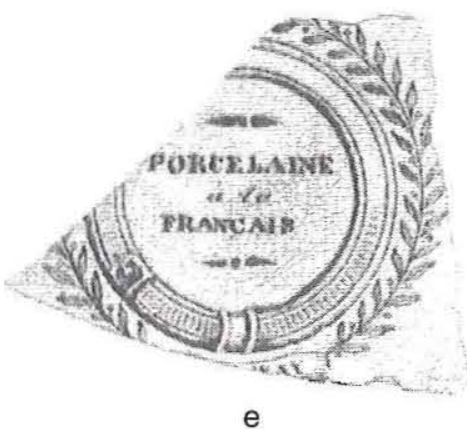

e

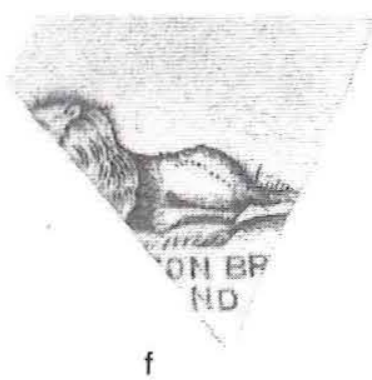

Figure 34. Makers' marks. (a) W. \& E. Corn; (b) Powell \& Bishop; (c) mark with English shield; (d) Homer Laughlin; (e) unidentified garter mark; $(f)$ unidentified mark with lion. 
Lehner 1988:117). This mark is printed "CROWN POTTERIES CO. .." over a crown with the bottom of the mark missing. Another partial mark that is also green printed and has "C.P." below a crown is also from Crown Potteries. This company was in business between 1891 and 1955 (Lehner 1988:117). The Canonsburg China Company is represented by a black-printed mark on a decal-decorated plate. This mark was used early in the life of the company and likely dates between 1901 and 1909 (Lehner 1988:74).

Table 7 shows the 21 potentially identifiable marks, and two of these are illustrated in Figure 34e and $f$. The first three listed are from England, while the remainder have not been identified to country of origin.

\section{PIPES}

Most of the pipe fragments are of the shortstemmed variety $(n=48)$. Only two sherds of the common white ball clay, long-stemmed pipes were recovered. One of these is a stem with "GLASGOW" pressed into one side and "... LL" on the other. This was likely made by MacDougall who was in operation from either 1810 or 1846 until 1967 (Humphrey 1969:17-18). The other ball clay sherd is a bowl rim fragment. Also recovered were one bakolite pipe stem, the tip of one wood or bone pipe stem, and the tip of a bakolite or other early plastic pipe stem. Two tobacco tags, too corroded to read, were also found.

Forty short-stemmed pipe sherds are made from stoneware and eight from terra-cotta earthenware. This style of pipe was common during the nineteenth century and was made first by local potteries and later by establishments that made nothing but pipes. These pipes were designed to be fitted with a reed stem (Greer 1981:131).

Of the 48 short-stemmed pipe sherds, 19 are too small to determine if any decoration was present. Eight sherds show only a raised ridge encircling the rim of the pipe bowl. Seven are decorated around the bowl rim and the stem with a continuous pattern of X's (Figure 35a). Five rim sherds are decorated with a continuous line of dots surrounded with circles (Figure $35 b$ ). Four sherds are decorated around the bowl with a continuous pattern of arrows (Figure $35 c$ ). Three pipe bowl sherds are ribbed and two are decorated with crosshatching. Paste colors range from gray to orange, and 12 sherds are glazed. No information regarding maker is available as these pieces are unmarked.

\section{SPOONS}

Of the 11 utensils, only 2 spoons with identifiable marks were recovered, both from the ground surface under the dining room porch. One is a small silver teaspoon marked only with the initials "R.C.CO." This mark was used by the Rogers Cutlery

Table 7. Potentially Identifiable Marks on Nontransfer-Printed Ceramics

\begin{tabular}{|c|c|c|c|c|}
\hline Mark & Method & Type & Color & No. of Sherds \\
\hline$\ldots /$ FENTON & impressed & garter & - & 1 \\
\hline$\ldots$ GLAND/. . NA & printed & royal arms? & black & 1 \\
\hline BURSLEM/STAFFORDSHIRE . & impressed & - & - & 2 \\
\hline$\ldots$. \& CO./. . . LAND & printed & - & black & 1 \\
\hline ... E CHINA & printed & royal arms & black & 1 \\
\hline . . . N DROIT/ . . GHES & printed & royal arms & black & 1 \\
\hline$\ldots \mathrm{NA}$ & printed & royal arms & black & 1 \\
\hline ... ON BROs/. . . LAND & printed & royal arms & black & 2 \\
\hline . . . ON BROS/. . . ND (see Figure 34f) & printed & lion & black & 2 \\
\hline C.P. & printed & shield & brown & 1 \\
\hline C.P. & printed & - & black & 1 \\
\hline CLASSI ... & printed & - & black & 1 \\
\hline H. A. \& Co. & impressed & - & - & 1 \\
\hline IM . . . /IRONST . . /JO . . . & printed & - & black & 1 \\
\hline IR $\ldots$ & printed & royal arms & black & 1 \\
\hline IRO . . /TRADE & printed & - & black & 1 \\
\hline IRONSTO . . . & printed & royal arms & black & 1 \\
\hline IRONSTONE & printed & - & black & 1 \\
\hline J. \& ... & printed & royal arms & black & 1 \\
\hline PORCELAINE a la FRANCAIS (see Figure $34 e$ ) & printed & garter & black & 1 \\
\hline WARRANTE . . . & printed & royal arms (early) & black & 1 \\
\hline
\end{tabular}



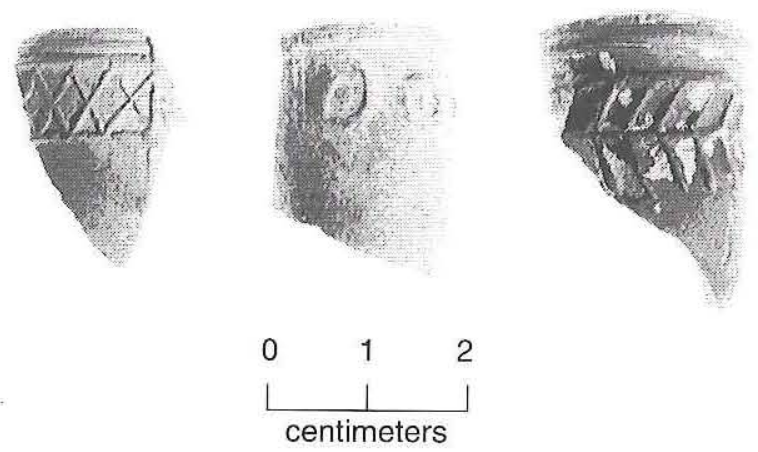

Figure 35. Pipe fragments.

Company of Hartford, Connecticut, from 1871 until 1898 (Woodhead 1991:209). The other is a silver plate tablespoon marked "OXFORD SILVER PLATE CO." from William A. Rogers, Limited, also of Hartford, Connecticut, and New York, New York. This company was in business from 1894 to 1929 and was succeeded by Oneida, Limited, which is still in operation (Woodhead 1991:208).

\section{COINS}

Eighteen coins-six pennies, six nickels, four dimes, one half-dollar, and one Guatemalan 10 centavos-were recovered. These coins range in date from 1840 to 1978 (Table 8). Four were minted in Denver.

Table 8. Coins

\begin{tabular}{lll}
\hline Denomination & Year & Mint \\
\hline penny & 1919 & none \\
penny & 1925 & "D" \\
penny & 1948 & "D" \\
penny & 1950 & none \\
penny & 1978 & "D" \\
penny & 1984 & none \\
nickel & 1867 & none \\
nickel & 1903 & none \\
nickel & 1917 & "D" \\
nickel & 1918 & none \\
nickel & 1965 & none \\
nickel & 1972 & none \\
dime & 1840 & none \\
dime & 1856 & none \\
dime & 1888 & none \\
dime & 1892 & none \\
half-dollar & 1893 & none \\
10 centavos & 1965 & - \\
\hline
\end{tabular}

\section{ARMS AND AMIMUNITION}

A total of 689 gun-related artifacts were found at Fanthorp Inn. Forty-three of these are bullets. Diameter measurements of bullets were taken at the least warped, most proximal end when possible. Twelve bullets are too damaged for measurement; the remainder have the following diameters (in inches): $.20(\mathrm{n}=2) ; .21(\mathrm{n}=6) ; .22(\mathrm{n}=4) ; .23(\mathrm{n}=1) ; .25(\mathrm{n}$ $=1) ; .30(\mathrm{n}=1) ; .31(\mathrm{n}=2) ; .35-.36(\mathrm{n}=1) ; .36(\mathrm{n}=$ 9); .36-.37 ( $\mathrm{n}=1) ; .37(\mathrm{n}=1)$; and $.45(\mathrm{n}=2)$. Six lead pellets were also recovered, as were two primers.

Evidence for single-shot, muzzleloading firearms is found in 31 large lead balls (ranging from .30 to .45 caliber), 5 gunflints (all dark gray and indicative of British sources; Figure 36a-e)), and a frizzen or striking platform for a flintlock gun (Figure 36f). Fifty-two percussion caps were also found. These were used on both caplock guns and early revolvers. Other gun parts include a barrel from a caplock handgun, which is highly corroded but appears to have been a .45 caliber (Figure $36 \mathrm{~g}$ ). Also found was a five-shot chamber for a .30- or .31-caliber breachloading revolver (Figure 36h). A hammer was also recovered (Figure 36i).

A total of seventy-eight .22-caliber rimfire cartridges were found (Table 9). Makers for these cartridges include Peters Cartridge Company (PCC) (n =4); the Peters Cartridge division of Remington Arms Company (Peters-REM) $(n=4)$; Union Metallic Cartridge Company (UMC), Remington Arms-Union Metallic Cartridge Company (REM-UMC), and Remington Arms Company (REM) $(n=21)$; United States Cartridge Company (USC or US) $(n=2)$; Western Cartridge Company (WCC) $(\mathrm{n}=6)$; and Winchester/Western or Winchester Repeating Arms Company (WW or WRA) $(\mathrm{n}=34)$. Seven $.22 \mathrm{~s}$ do not have headstamps. Both rifles and handguns can utilize .22-caliber cartridges, so any determination of use would be speculative. Of the 78 cartridges, 39 are "short" (.43 inch long), 32 are "long" (.61 inch long), 4 are "extra long" (.96 inch long), 2 are "BB"s (.26 inch long), and 1 is an unfired blank round. Seventeen of the long cartridges are relatively recent unfired hollow points, probably intended for hunting on the property. Most of these cartridges have very long date ranges, but a few have shorter ranges that indicate the time period in which they were used. Specifically, the four .22 short cartridges from PCC date 1895-1934, placing them in the period when Judge McDonald lived at the site. The two .22 shorts made by USC date between 1869 and 1936, placing them between the inn operation period and the end of Judge McDonald's 


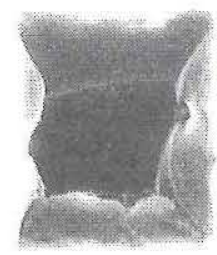

a

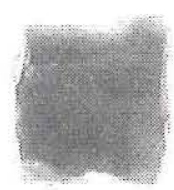

b

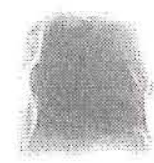

C

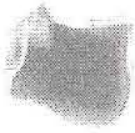

d

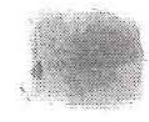

e

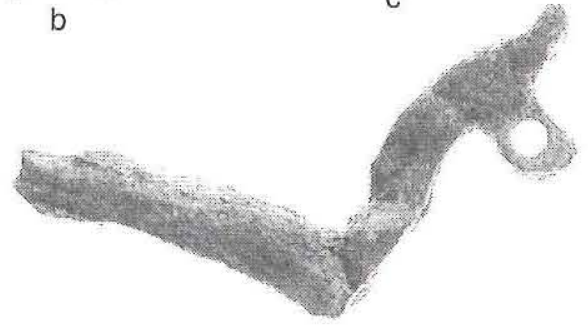

f

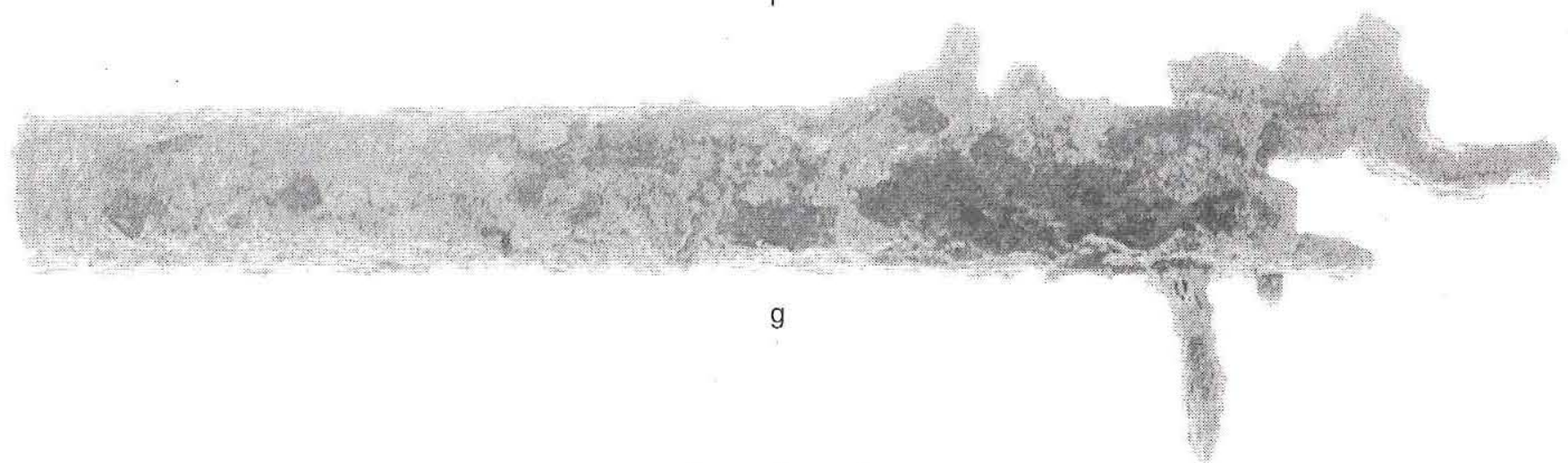

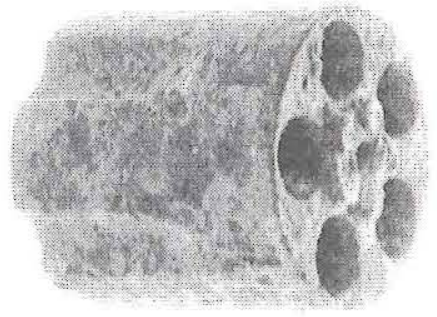

h

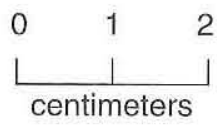

centimeters

Figure 36. Gun accoutrements and parts. (a-e) Gunflints; $(f)$ frizzen; $(g)$ gun barrel; $(h)$ chamber; $(i)$ hammer.

occupation. The three .22 longs and the one blank from Peters-REM date between 1934 and the 1960s, after the Judge had left the property.

Two unmarked rimfire cartridges appear to be .30 shorts. This type of ammunition was used as early as the 1860s and was last advertised ca. 1919 (Barnes 1993:372). The only other unmarked rimfire cartridge is the same size as a .41 short. This round was introduced in 1863 with the National Arms Company breechloading derringer but has been obsolete since World War II (Barnes 1993:375).

Twelve .32-caliber cartridges were found. Ten of these are Smith and Wesson (S\&W) revolver cartridges, a round that was introduced in 1878 and is still used (Barnes 1993:224). One is a .32 Short Colt introducted in 1875 and made obsolete by the .32 $\mathrm{S} \& \mathrm{~W}$. Colt is the only company that used this cartridge in the United States (Barnes 1993:226). The last cartridge is a Winchester .32 or .32-20 which was primarily a rifle cartridge but was also a popular handgun cartridge (Barnes 1993:226). This round was introduced in 1882 and was used by most gun manufacturers in the United States (Barnes 1993:66).

Sixty-nine .38-caliber cartridges were recovered. The makers represented are CCC, UMC, REM-UMC, PCC, S\&W, US, USC, and WRA. At least 4 are for Winchester rifles, 4 are for .380 automatic cartridges ( 3 of which are unfired), 1 is for an automatic Colt, 5 
Table 9. Cartridges

\begin{tabular}{|c|c|c|c|c|}
\hline Caliber & Headstamp & Maker & No. & Dates \\
\hline $.22 \mathrm{BB}$ & - & - & 2 & - \\
\hline .22 long & - & - & 1 & - \\
\hline .22 short & - & - & 4 & - \\
\hline .22 extra long & $\mathrm{H}$ & WRA, WW & 4 & post-1867 \\
\hline .22 long & $\mathrm{H}$ & WRA, WW & 18 & post- 1867 \\
\hline .22 short & $\mathrm{H}$ & WRA, WW & 12 & post- 1867 \\
\hline .22 blank & $\mathrm{P}$ & Peters-REM & 1 & $1934-1960 \mathrm{~s}$ \\
\hline .22 long & $\mathrm{P}$ & Peters-REM & 3 & $1934-1960 \mathrm{~s}$ \\
\hline .22 short & $\mathrm{P}$ & PPC & 4 & $1895-1934$ \\
\hline .22 long & $\mathrm{U}$ & UMC, REM-UMC, REM & 5 & post- 1867 \\
\hline .22 short & $\mathrm{U}$ & UMC, REM-UMC, REM & 16 & post- 1867 \\
\hline .22 short & US & USC & 2 & $1869-1936$ \\
\hline .22 long & diamond & WCC & 5 & post-1908 \\
\hline .22 short & diamond & WCC & 1 & post-1908 \\
\hline .30 short? & - & - & 2 & ca. 1860 -са. 1919 \\
\hline .32 & - & - & 1 & - \\
\hline .32 & REM-UMC/.32 S\&W & REM-UMC & 2 & post-ca. 1912 \\
\hline .32 & $\mathrm{~S} \& \mathrm{~W} / 32$ & $\mathrm{~S} \& \mathrm{~W}$ & 1 & post- 1878 \\
\hline .32 & U.M.C./.32 S\&W & UMC & 2 & 1878-ca. 1912 \\
\hline .32 & U.S.I.32 S\&W & US & 2 & $1878-1926$ \\
\hline .32 & W.R.A. Co./.32 A.C. & WRA & 1 & post-1875 \\
\hline .32 & W.R.A. Co./32 S\&W & WRA & 1 & post- 1878 \\
\hline .32 & WRA Co./32 S\&W & WRA & 1 & post- 1878 \\
\hline $.32-20$ & WRA CO/32 W.C.F. & WRA & 1 & post-1882 \\
\hline .38 & - & - & 6 & - \\
\hline .38 & C.C.C./S H/38 S\&W & $\mathrm{CCC}$ & 1 & $1890-1892$ \\
\hline .38 & PETERS/.36 S\&W SPL. & $\mathrm{PCC}$ & 3 & $1902-1962$ \\
\hline .38 & REM-UMC/38 W\&W SPL & REM-UMC & 9 & post-ca. 1912 \\
\hline .38 & REM-UMC/38 SPL & REM-UMC & 1 & post-ca. 1912 \\
\hline .38 & REM-UMC/38 WCF & REM-UMC & 1 & post-ca. 1912 \\
\hline .38 & $\mathrm{~S} \& \mathrm{~W} / 38$ & S\&W & 1 & - \\
\hline .38 & U. .. C. $/ 38 \mathrm{~S} \& W$ SPL & USC or UMC & 1 & - \\
\hline .38 & U.M.C./.38 C.F.W. & UMC & 2 & 1867-ca. 1912 \\
\hline .38 & U.M.C./.38 S\&W & UMC & 1 & 1877-ca. 1912 \\
\hline .38 & U.M.C./38 S\&W SPL. & UMC & 3 & 1902-ca. 1912 \\
\hline .38 & U.M.C./S H/.36 LONG & UMC & 1 & $1875-1900$ \\
\hline .38 & U.M.C./S H/.38 S\&W & UMC & 4 & 1867-ca. 1912 \\
\hline .38 & U.S./38 S\&W & US & 2 & $1869-1926$ \\
\hline .38 & U.S./38 S\&W SPECIAL & US & 1 & $1902-1926$ \\
\hline .38 & U.S.C. CO./38 LONG & USC & 1 & $1875-1900$ \\
\hline .38 & U.S.C. Co./38 S\&W SPL & USC & 3 & $1902-1926$ \\
\hline .38 & US/38 LONG? & US & 1 & $1875-1900$ \\
\hline .38 & W.R.A. CO/38 LONG & WRA & 2 & $1875-1900$ \\
\hline .38 & W.R.A. CO./.38 A C & WRA & 1 & post- 1900 \\
\hline .38 & W.R.A. CO./.38 S.\&W. & WRA & 14 & post-1877 \\
\hline .38 & W.R.A. Co./38 S \& W SPL & WRA & 5 & post-1902 \\
\hline .380 & USC/380 CAPH; mark on primer & USC & 1 & $1908-1926$ \\
\hline .380 & U.S.C. Co./380 CAPH & USC & 1 & $1908-1926$ \\
\hline .380 & UMC/380 CAPH; "U" on primer & UMC & 2 & 1908-ca. 1912 \\
\hline $.38-40$ & U.M.C. $/ .38-40$ & UMC & 1 & 1867-ca. 1912 \\
\hline .41 & U.M.C./41 L.C. & UMC & 2 & 1877-ca. 1912 \\
\hline .41 & W.R.A Co./.41 L.D.A. & WRA & 3 & 1877-ca. 1912 \\
\hline .41 short? & - & - & 1 & 1863-ca. 1945 \\
\hline .44 & - & - & 1 & - \\
\hline .44 & - & - & 2 & 1868-ca. 1940 \\
\hline .44 & REM-UMCl.44 S\&W SPL & REM-UMC & 1 & post-ca. 1912 \\
\hline .44 & WESTERN/.44 S\&W SPL & WCC & 3 & post- 1908 \\
\hline
\end{tabular}




\begin{tabular}{lllrl}
\hline Caliber & Headstamp & Maker & No. & Dates \\
\hline .44 & WRA Co/44 B.D. & WRA & 1 & ca. 1880-ca. 1939 \\
$.44-40$ & - & - & 1 & $1873-1942$ \\
$.44-40$ & U.M.C./.44-40 & UMC & 11 & $1873-$ ca. 1912 \\
$.44-40$ & W.R.A. Co./44 W.C.F. & WRA & 2 & $1873-1942$ \\
.45 & REM-UMC/.45 ACP & REM-UMC & 1 & post-ca. 1912 \\
.45 & U.M.C./.45 COLT & UMC & 2 & 1873 -ca. 1912 \\
.45 & U.S.C. Co./45 A.C.P. & USC & 1 & $1905-1926$ \\
.45 & WRA Co/45 COLT & WRA & 6 & post-1873 \\
\hline
\end{tabular}

are for rifles, 49 are for Smith and Wesson .38-caliber sidearms, and 6 are too corroded to determine use.

The three undischarged .380 cartridges have marks on the primer as well as around the rim. The .380 automatic was designed by John Browning and added to the Colt Pocket Automatic line in 1908. Many companies have made pistols in this caliber in both the United States and Europe, including Colt, Remington, Browning, and Beretta (Barnes 1993: 239). Two of the four .380 cartridges were made by USC (marked "U.S.C. Co." and "USC" with "380 CAPH") which was in business until 1936; the other two are marked "UMC" denoting the Union Metallic Cartridge Company, a mark that was not used after ca. 1912 (White and Munhall [1977:148] claim that the mark was used until Remington took over the company in 1911, while Flayderman [1980:140] states that the takeover occurred in 1912; 1916 also has been claimed as the date). In any case, the two made by UMC provide a tight date of 1908-ca. 1912; the others date 1908-1936, and all may relate to use of a single gun of this caliber during Judge MacDonald's residence. The other .38-caliber automatic cartridge is slightly longer. This cartridge was designed by John Browning and introducted by Colt in 1900 for their .38 automatic (Barnes 1993:238).

Four of the .38-caliber cartridges found were commonly used as rifle cartridges but could also have been revolver rounds ( 1.30 inches long, .52-inch basal diameter). All four are believed to be for Winchesters, one being marked "REM-UMC/38 WCF" and two marked "UMC/38 C.F.W." (Winchester Centerfire or Centerfire Winchester). The fourth is marked "U.M.C./.38-40" but is the same size and shape as the other three. The three marked "UMC" predate ca. 1912 while the "REM-UMC" cartridge postdates this. This cartridge was used from the 1870 s and continues to be made for revolvers, while rifles that used this ammunition were not made after 1937 (Barnes 1993: 84). Five .38-caliber cartridges designated as "LONG" were found. These cartridges are 1.02 inches long and .44 inch in basal diameter. The Long centerfire cartridge was introduced in 1875-1876 and was used in many rifles. By 1900 it was obsolete (Barnes 1993:118). Versions of this cartridge were found made by UMC, USC, and WRA.

Of the forty-nine .38-caliber Smith and Wesson revolver cartridges, 25 are marked "SPECIAL" or "SPL." This round was introduced by Smith and Wesson in 1902 and is still used today (Barnes 1993:237). The dimensions of the Special round are 1.15 inches long and .44 inch in basal diameter. The .38 SPL cartridges found are made by PCC, REMUMC, UMC, USC, and WRA. The other 24 Smith and Wesson cartridges were just marked ".38 S\&W" with the maker designation. These cartridges are .77 inch long and .44 inch in basal diameter. Developed in 1877 by Smith and Wesson, this cartridge is still widely used today (Barnes 1993:238). The .38 S\&W cartridges found at Fanthorp were made by the Creedmoor Cartridge Co. (CCC), UMC, USC, and WRA. Three of the six cartridges on which the headstamp can no longer be read are the size of the .38 Smith and Wesson cartridges. Another is likely a Smith and Wesson Special, and the length of the other two cannot be determined.

Five .41-caliber cartridges were found. Two were produced by UMC and are marked " 41 L.C.," while the other three were made by WRA and marked ".41 L.D.A." The 41 Long Colt was introduced in 1877; no revolvers have been made for this round since the 1930s (Barnes 1993:241). The case is 1.13 inches long with a basal diameter of .44 inch.

Four Smith and Wesson .44 Special revolver cartridges were found, one by REM-UMC and the others by WCC. These cartridges are 1.16 inches long with a basal diameter of .51 inch. This cartridge was introduced ca. 1907 (Barnes 1993:245). Fourteen Winchester .44 (.44-40) cartridges were recovered. This was a popular round for both rifles and revolvers. The .44-40 Winchester was introduced with their Model 1873 lever-action repeating rifle. The last American-made model to be chambered for this round was made in 1937. This round was made for revolvers until 1942 (Barnes 1993:88). One cartridge is marked "WRA Co./44 B.D." This cartridge was used in the 
Webley's British Bull Dog revolver. First introduced ca. 1880, the round was loaded up to ca. 1939 (Barnes 1993:247). This round and gun were used primarily for personal defense. Three other .44 rounds without legible markings were found. One was blown apart during use and is not identifiable beyond being a .44 , but the other two are .69 inch long and .51 inch in basal diameter and appear to be for a .44 Webley, which originated in Ireland in 1868. It was loaded in the United States as the .44 Webley up to ca. 1940 (Barnes 1993:244).

Two .45 Automatic (ACP) cartridges were found. This round was developed by John Browning in 1905 and is still used as a military ordnance today. Primarily used as a revolver cartridge, several submachine guns have used it, and a semiautomatic rifle was also marketed in this caliber in 1943 (Barnes 1993:249). These cases are .89 inch long with a basal diameter of .47 inch. Eight .45 Colt revolver cartridges were also recovered. This round was first produced by Colt in 1873 for their "Peacemaker" single-action revolver. This is one of the most famous American cartridges, and it was used extensively throughout the American West (Barnes 1993:250).

Nineteen shotshells were recovered (Table 10). These include a .410 , four 10 gauge, eleven 12 gauge, and three 16 gauge; makers include UMC, Peters, REM-UMC, USC, and Winchester. Also reflecting use of shotguns are 328 pieces of shot smaller than .32 inch in diameter (except for one specimen measuring .30 inch that was included with the large lead balls used with single-shot muzzleloading firearms because it has mold seams).

A minimum of 11 revolvers, 2 rifles, 5 rifles or revolvers, and 4 shotguns are represented by the ammunition. A barrel and a chamber from different revolvers were also recovered (see Figure $36 g, h$ ). This large number of gun-related artifacts is indicative of hunting, target shooting, and self-defense. It is likely that the revolver rounds indicate target shooting or self-defense activities, while the rifle cartridges and shotshells represent hunting. Many of the cartridges could have been used in either rifles or revolvers, so these are only gross generalizations.

\section{TOYS}

\section{Dolls and Doll Parts}

From the mid-nineteenth century up until World War I, porcelain dolls enjoyed enormous popularity (Tosa 1987:20). One hundred and forty-six sherds of porcelain dolls and one complete doll were identified during this analysis. The majority of the fragments are from doll heads $(n=112)$, but arms $(n=12)$, legs ( $=15)$, torso fragments $(n=3)$, eyes $(n=3)$, and an unidentified limb fragment were also found. Thirteen bisque head fragments show partial impressed or incised makers' marks. Four of these show portions of the name "Germany" while the other nine have numbers or illegible marks. All 13 of these are pink toned. Germany was the major producer of porcelain dolls in the late nineteenth century (Foulke 1995:15), and when World War I started, the trade with this country ended. Of the other head fragments, five stand out in particular. Two are unpainted glazed heads (one almost complete, one partial) that have no separate elements such as glass eyes or hair. All of the features are molded into the head. This type of doll head was molded to the shoulder and was used as the head on a cloth body. Dolls like this were popular from the midnineteenth century: The nearly complete specimen has a flat-top hairdo (Figure 37a), and both dolls appear to represent children, a style common in the 1880 s (Foulke 1995:75). A small head fragment that includes the face and brown-painted hairline was also

Table 10. Shotshells

\begin{tabular}{cllcl}
\hline Gauge & Headstamp & Maker & No. & Date \\
\hline$?$ & PETERS / 12 M/M /.410 HV & PCC & 1 & $1895-1934$ \\
10 & USC CO. / No. 10 / CLIMAX & USC & 1 & $1869-1926$ \\
10 & U.M.C. Co. / No. 10 / CLUB & UMC & 2 & $1873-$ ca. 1912 \\
$10 ?$ & . . / No. . . / CLUB & - & 1 & - \\
12 & U M C CO / No. 12 & UMC & 1 & $1873-$ ca.1912 \\
12 & U.M.C. Co. / No. 12 / NEW CLUB & UMC & 4 & $1873-$ ca. 1912 \\
12 & REM-UMC / No. 12 / NEW CLUB & REM-UMC & 2 & post-ca. 1912 \\
12 & REM-UMC / No. 12 / NITRO CLUB & REM-UMC & 1 & post-ca. 1912 \\
12 & WINCHESTER / No. 12 / NUBLACK & WRA & 2 & post-1867 \\
$12 ?$ & REM . . / No. . / NEW C . . & REM-UMC & 1 & post-ca. 1912 \\
16 & REM-UMC / No. 16 / NEW CLUB & REM-UMC & 2 & post-ca. 1912 \\
16 & WINCHESTER / No. 16 NEW RIVAL & WRA & 1 & post-1867 \\
\hline
\end{tabular}




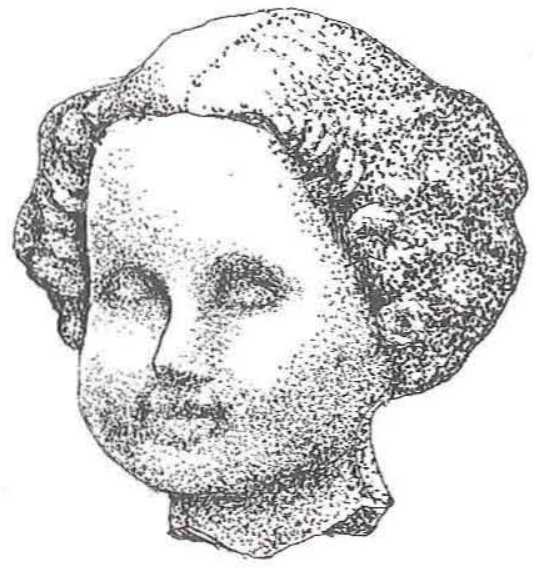

a
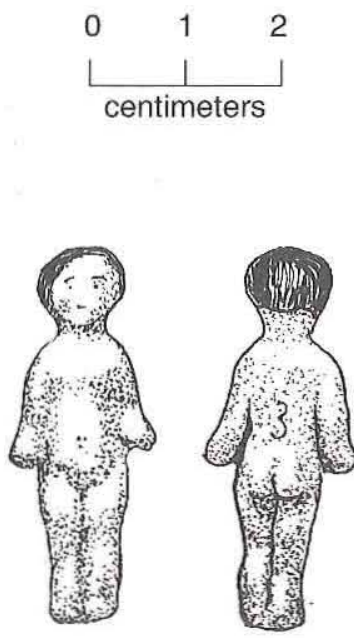

d

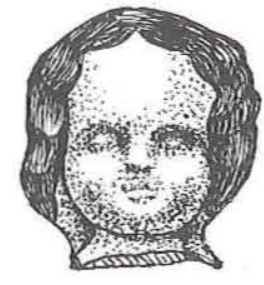

b
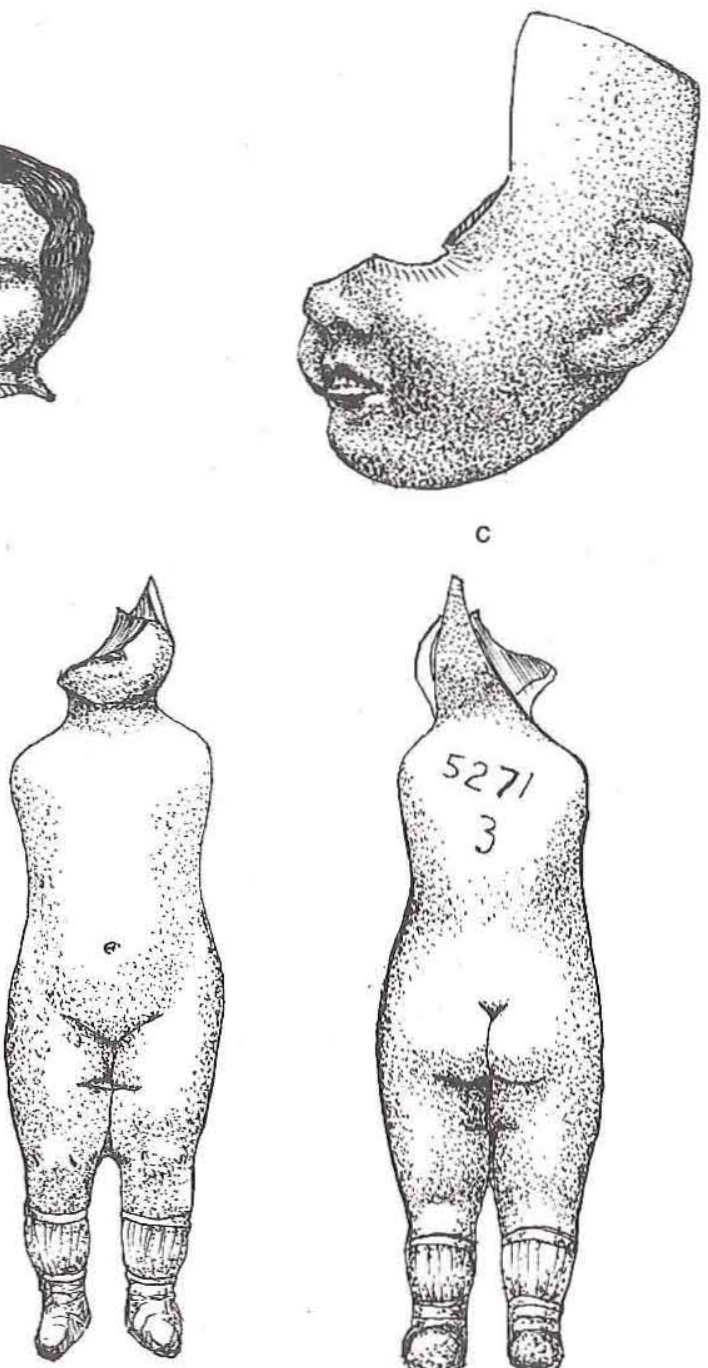

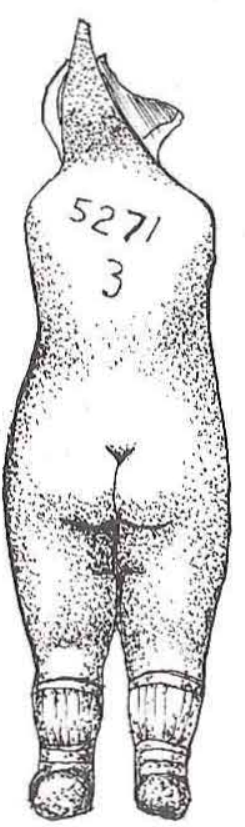

e

Figure 37. Dolls. (a) Unpainted glazed molded head; $(b)$ small molded head; $(c)$ pink head with partial socket for glass eye; (d) Frozen Charlotte doll; (e) child doll.

collected (Figure 37b). This piece is similar to the styles popular in the 1860 s, but since styles through the late nineteenth century resemble each other, it is difficult to accurately date these dolls to the correct decade. Two fragments of dolls that would have had glass eyes were recovered. One is undecorated and only shows the nose, mouth (including teeth), and right eye socket. The other is pink, has painted eyelashes, teeth, and lips, and maintains most of the left side of the face (Figure 37c). The top of the head was left hollow for the addition of fibrous hair (often real hair). Five other small pieces show pieces of eyelashes and/or eyebrows painted on the head, which would also have had separate hair and eyes.

Of the three glass eyes recovered, one is a solid pinched eye with a blue iris. Another is a blown hollow eye with a brown iris, and the last is a fragment of a blown hollow blue eye. The first patent for a glass doll eye was taken out in 1855 by ClaudeJoseph Blampoix, a Parisian doll maker (Tosa 1987:27). Often found in bisque doll heads, glass eyes are not usually found in glazed porcelain heads (Coleman et al. 1968:219).

Two of the 12 arms are from articulated porcelain dolls; three would have been sewn into a cloth doll. The other 7 fragments are hands in a variety of shapes and sizes. Of the 15 legs and fragments, a minimum of 7 are the style that would have been sewn into a cloth doll body. Only 1 would have been part of an articulated porcelain doll and 
appears to be wearing an early-twentieth-century style of shoe. The other 7 shoes in the collection are simply brown glaze with no particular details.

One complete Frozen Charlotte doll was found. Frozen Charlottes were molded in one piece and were also known as bathing dolls as they could be immersed in water. This tiny doll, only 1.5 inches tall, has black hair, eyes, and eyebrows, and red lips and cheeks (Figure 37d). These dolls were first introduced in the 1850s and were on the market for 65 years (Foulke 1995:84; Tosa 1987:150). The only other almost complete doll was found in three sherds. This appears to be a baby or child doll about 3.5 inches tall, with articulated arms and fixed legs. The child is wearing white socks with green trim and blue shoes (Figure 37e). The torso fragment of an articulated doll was also recovered.

\section{Marbles}

Marbles are typically made from agate, glass, clay, or porcelain. Clay is distinguished from porcelain here by including only the white marbles under porcelain and counting the gray, orange, and brown ceramic marbles as clay. Marbles were sold to the public by material and size, of which there was a continuum from less than $1 / 2$ inch in diameter to nearly 2 inches. Of the 59 marbles, 29 are made of clay, 15 of glass, 14 of porcelain, and 1 of agate. The glass marbles are found in the earlier handmade variety, as well as the later machine-made types.

Over half $(n=31)$ of the marbles were recovered from under the dining room porch, and nine others are from surrounding areas including the back yard next to the porch, the dining room, and Room 106. Of the eight handmade glass marbles, six were found under the porch, but machine-made marbles were also found there, indicating that the back porch was used as a marble-playing area for many years. Handmade marbles were made in Germany by 1846 and were produced in the United States from 1880 to 1882 and 1897 to 1902 (Randall 1979:7, 15). The oldest handmade marbles have two pontil marks, while according to Grist (1993), during the "transition period" of 1880 to 1915 when the machinery to produce marbles was being perfected, handmade marbles had a single pontil. All of the handmade marbles from Fanthorp have two pontil marks likely dating them, according to Grist (1993), to pre-1880. The machine-made marbles generally date after World War I, and by the mid to late 1930s, machine-made marbles were the only type sold in any quantity (Randall 1979:18). 


\section{AFRICAN AMERICAN SPIRITUALITY AT FANTHORP INN}

Certain artifacts found at Fanthorp Inn may reflect the practice of African American religion. The particular specimens discussed in this chapter include 16 quartz crystals, a group of artifacts believed to be a nkisi (plural minkisi), or African spirit bundle, and 2 marine shells. The following discussion presents background information on African American religious practices, a review of archeological research where crystals and minkisi have been found, a description of the artifacts from Fanthorp that are interpreted as being of possible African American use, and a discussion of how the artifacts at Fanthorp can be interpreted. This chapter does not chronicle the social complexities of the lives of African American slaves; rather, it provides the background necessary to understand the findings and interpretations of certain aspects of the archeological record at Fanthorp Inn.

Through the course of this chapter, the terms "spiritual," "religious," and "religion" are used to denote those practices that are related in one form or another to the spiritual realm, such as conjuring spirits, divining, curing, etc. To the practitioner, these are probably not seen as solely spiritual acts, but instead as incorporating the body, mind, and spirit.

\section{AFRICAN AND AFRICAN AMERICAN RELIGIOUS PRACTICES: A BRIEF BACKGROUND}

The majority of the slaves imported to the United States were from the west coast of Africa, but some came from Central, South, and East Africa, as well as Madagascar (Stampp 1956:9). Similarities can be seen among African belief systems from across that continent, as most incorporate contact with the spirits through divination, curing, witchcraft, and sorcery (Bamunoba 1979:52-55; Deschamps 1970:60-67; Jones 1995:6; Silverthorne 1986:155-158; Wilson 1971:26-51; Zahan 1979), and "... associated ceremonies used objects that came from the land or were reused or created from locally available materials" (Patten 1992:6). These Africans were shipped to the United States and dispersed throughout the South creating a situation where "an enslaved African would meet more Africans from more ethnic groups than he or she would encounter in a lifetime in Africa" (Joyner 1989:2, quoted in Young 1996:6). In this manner, different African belief systems came together under the oppression of slavery and the influence of Christianity, Judaism, and Native American religions to form unique and new belief systems (Genovese 1976:209). By the 1830s, these new belief systems were integral parts of the culture of the American South.

Christianity is often seen as the major religious influence on the African American slaves, but many researchers agree that African religious practices were incorporated into an African American Christianity (Jones 1995:5), and archeological evidence supports the continued use of African-influenced spiritual practices. African spiritual practices and Christianity were not seen as contradictory beliefs, but were often viewed as complementary ideologies by the African Americans practicing them. Just because there is evidence in the archeological record for divining or conjuring does not mean that the slaves were not also Christian.

African American religions were created or influenced by the varied beliefs and practices of African and African American slaves, the religious beliefs of their owners, and the social and economic situations into which they were forced (Alho 1980:43; Genovese 1976:209; Mintz and Price 1976, paraphrased in Jones 1995:5-6). The spirituality of the slaves, the social oppression under which they were forced to live, and the economic oppression they experienced under slavery cannot be considered separately. They affected each other in sometimes subtle, sometimes overt ways, and the archeological record should reflect all three.

Striking similarities in the archeological deposits from African American sites across the South do not necessarily indicate that one standard African American religion existed everywhere, but rather that 
similar social and economic situations combined with the underlying commonalities of all African religions to create continuities in the archeological deposits. A single "African American Religion" does not exist and never did, but generalizations about African American religion are made here because these continuities are seen.

Outside of Christianity, the religious or spiritual practices of African American slaves in the United States are not well documented in the historical records of the time. For that matter, the lives of the slaves and their activities are poorly recorded in general. What little information is available about religion in the slave quarters has been gleaned from narratives written after the Civil War. Particularly important are the thousands of interviews conducted across the South by the Works Progress Administration during the 1930s. Most researchers in this area rely heavily on these narratives for information about religious beliefs (Silverthorne 1986:XV). The most important aspect of the slave culture with regard to the present research is that magic and conjuring were commonly practiced. Slave narratives from the late nineteenth century record "... an almost universal faith in the conjuror" (Blassingame 1976:143). The conjurer was a respected member of the community and often held the highest position of esteem on the slave social ladder, even above the preacher (Blassingame 1976:142).

Both African and African American conjurers or diviners are known to have used quartz crystals in their work. In the African practice of divining, objects from the natural world (amulets) are often used. Shells (particularly cowrie), horns, stones, sticks, skins of various animals, gourds, bells, and other objects are used by many different African societies in such practices (Deschamps 1970:61). Of particular interest here is the mention of a practice by diviners in West Cameroon (located southeast of Nigeria on the west coast of Africa), as their work incorporated the use of quartz crystals:

Le panier divinatoire est utilisé dans L'Ouest-Cameroun. Il contient des éscailles de pangolin de formes diverses, des cristaux de roche, des écorces, des coquilles, des os, des pinces de crabe, des perles, des grelots, etc. Le devin fait tourner le panier et jette à terre son contenu : la desposition des objets donne la réponse [Deschamps 1970:62].

Translated:
The divining basket is used in West Cameroon. It contains the scales of the pangolin, quartz crystals, bark, shells, bones, crab pinchers, pearls, bells, etc. The diviner will turn the basket and throw its contents on the ground: the position of the objects determines the action to be taken.

The Bakongo also used quartz crystals in making their minkisi (Jones 1995; MacGaffey 1991; Patten 1992; Thompson 1983:118; Young 1996:5). Minkisi are powerful spiritual bundles which have lives and souls of their own and are generally composed of a container filled with specific medicine. The containers used can be made of many materials, including, but not limited to, leaves, shells, packets, gourds, pots, bags, or ceramic vessels (Thompson 1983:117). Some of the medicines that provide the minkisi with power are cemetery earth, white clay, chalk, nuts, plants, soil, stones, and charcoal, and they are placed in these vessels (Samford 1996:107; Thompson 1983:117). Minkisi are used by the Bakongo of Africa as well as African Americans to promote health, to attract good spirits, to repel evil spirits, etc. (Thompson 1983:117).

While there is relatively little written about the forbidden practices of the African American slaves, the Georgia Writers' Project's Drums and Shadows of 1940, written generations removed from the end of slavery, discusses some of the practices of the Africans in Georgia during the late 1930s. No references to the specific uses of crystals were found, but one comment makes a strong statement about the topic: "Washington uses no cards or crystals [in his fortune telling]" (Georgia Writers' Project 1940:39). The comment that James Washington, an African American fortuneteller and root doctor, specifically did not use crystals in telling the future implies that it was a common practice to use them and that he was the exception.

\section{ARCHEOLOGICAL EVIDENCE OF AFRICAN-INFLUENCED PRACTICES}

Orser (1994:34) points out that some researchers, such as E. F. Frazier (1964), have argued that slaves lost every aspect of their African culture during the trauma of being shipped to the Americas. Others, such as Melville Herskovits, maintain that many aspects of African material culture were lost, but that slaves retained other aspects of their culture including religion, methods of planting crops, postures of 
sitting, walking, speaking and dancing, hair styles, and concepts of time and punctuality (Herskovits 1958, paraphrased in Orser 1994:34; Jones 1995:5). Researchers in architecture have made correlations between African-style houses and slave quarters as well as common house styles such as the shotgun form (Jones 1985; Singleton 1988:351-352). African influences of design and form also have been noted on materials created by slaves including "... wood carving, pottery making, wrought iron fences and gates, architecture, and graveyard decoration" (Vlach 1978, paraphrased in Jones 1995:5). With the popular movement toward African American archeology and research in recent years, it is becoming clear that a significant amount of African-influenced material culture was produced and used during the time of slavery and after, and that the idea that slaves were somehow de-Africanized during their journey to the New World is wrong.

In the past 10 to 15 years, archeologists have noticed recurring patterns in the material culture from slave sites across the South. Natural items such as stones, shells, and dirt, as well as household items like spoons, buttons, marbles, bowls, and kettles, are often found at African American sites in contexts that indicate a different function than what is normally presumed (Brown and Cooper 1990; Jones 1995; Russell 1996; Thompson 1983; Young 1996). These ordinary artifacts found in nonordinary contexts are believed to have been used in forbidden religious, spiritual, or healing ways (Ferguson 1992; Klingelhofer 1987:114; Samford 1996:106; Singleton 1996; Young 1996). Common in African American slave sites are ordinary items that are often inscribed with geometric designs (stars, asterisks, etc.) or cosmograms (simple crosses, swastikas, crosses within circles, etc.). Activities associated with these items were able to be perpetuated in the slave communities because articles from nature or ubiquitous, everyday household items, if discovered by their owners, would not likely be identifiable to their specific use (Brown and Cooper 1990:17).

At many slave sites, quartz crystals have been recovered in good archeological contexts, often in association with other objects known to have been used in African divining practices, and they are believed to have been a common item used by the slaves in such acts (Jones 1995; Patten 1992). Although plentiful, the occurrence of quartz crystals at slave sites has not been widely published. Functionality becomes difficult to assign to an unmodified rock unless enough contextual evidence is collected, and until recently, evidence was not conclusive. One of the most important, informative, and well-known finds of this kind was made at the Charles Carroll house in Annapolis, Maryland-a white household where African Americans worked and may have lived-where a total of 19 quartz crystals were recovered. During this research, a cache including 12 of the 19 quartz crystals, several pieces of chipped quartz, a bead, and a polished black stone were found under an inverted British-made pearlware bowl. The group of artifacts was located under what would have been the floor, in a lower-floor room known to have been a work area for slaves and possibly a living area as well (Jones 1995:4; Logan 1992:4-5; Logan et al. 1992). On the interior base of the bowl an asterisk similar to a Bakongo cosmogram was part of the original handpainted pattern and suggests that the bowl was specifically chosen as a container for ceremonial objects because of its decoration. This group of artifacts has been interpreted as a diviner's kit (Fagan 1995:256; Jones 1995:2). Jones (1995) discusses the crystals found at Annapolis and associates them with the creation of minkisi, of which she gives many examples, but the inclusion of crystals in formal bundles does not appear to have been the only use for crystals by African Americans. Many, including those found at Fanthorp, were either found alone or not recorded as being in context with other potentially ritualistic objects.

At the Levi Jordan Plantation in Texas, two quartz crystals were found in the magician/curer's cabin. The crystals were found within the western quadrant of what is believed to be a cosmogram and may have been part of a nkisi used to protect the cabin and its occupants from harm (Brown 1994:114). A cosmogram is basically a cross (in no way associated with the crucifix) where the horizontal line represents the border between the material and the spiritual worlds and the vertical represents the pathway between the worlds (Thompson 1983:108). The western quadrant is associated with death, or passage from this world to the spirit world (Ken Brown, personal communication 1996).

At the Hermitage, Andrew Jackson's plantation near Nashville, Tennessee, 10 natural quartz crystals and 12 chandelier or lamp prisms were found in association with various slave quarters. An interesting split between the natural and manmade crystals is seen here with the lamp prisms associated with households near the mansion and the natural crystals associated with outlying quarters. None of these crystals were found in conspicuous locations, rather they were scattered through associated midden deposits (Larry McKee, personal communication 1997). At the Locust Grove site in Kentucky, several lamp prisms were excavated from two slave quarters but no natural 
crystals were found (Young 1996). Two sites having lamp prisms associated with the slave quarters indicate a possible functional correlation between natural crystals and lamp prisms. If this is the case, lamp crystals used in this capacity may have been found at other sites but simply not recognized for this function. Future research should take the context of prisms into account on slave sites, particularly in relation to other artifacts typically used for divining.

Klingelhofer (1987:116) notes the recovery of a large natural crystal from a slave site at Jefferson's Monticello in Virginia, and Jones (1995:9) notes crystals found in the excavations at Monticello's Mulberry Row. Klingelhofer (1987:116) also notes the discovery of ". . . a 3 inch diameter spherical quartzite stone with three of the six possible perpendicular faces flattened at a probable slave site near the Chicahominy River."

The Manassas National Battlefield Park in Virginia is home to two sites where crystals have been recovered from African American contexts: the Nash and Brownsville sites (Galke 1992a). At the Nash site, six quartz crystals, a fragment of galena, and a quartz projectile point were recovered in a cache associated with the chimney in an African American building (either a slave quarter or free black house), and three other crystals were found in separate contexts (Galke 1992a:137, 1992b:10). At the Brownsville site, a small single cluster of quartz crystals was found in mixed deposits of the cellar of one of the buildings possibly used by African Americans (Galke 1992a:79).

From the Brush Evarard House in Colonial Williamsburg, Virginia, a smoky quartz crystal, a cowrie shell, and a pierced coin were excavated from a context associated with African Americans dating to the eighteenth century (Jones 1995:10; Patten 1992:6). Other sites yielding quartz crystals include Thomas Jefferson's Poplar Forest in Virginia, Mount Clare in Maryland, and Jefferson's Shadwell birthplace in Virginia (Jones 1995:10; Patten 1992:6). These cases of crystals and lamp prisms found at African American sites provide firm evidence that African Americans used these objects frequently and consistently from Virginia to Georgia and Texas.

Evidence for minkisi has been found at archeological sites also, but relatively few examples have been recorded due to a lack of knowledge of such artifacts. Many more occurrences may be unidentified or misinterpreted. Clusters of objects that are interpreted as minkisi have been discovered in the walls of at least two slave quarters: the Eno Quarter in Durham County, North Carolina, and a slave house at Prestwould Plantation in Mecklenburg County,
Virginia. The objects found include ". . . a bottle containing a button, several cloth sugar and tobacco bags holding plant material, and an iron knife" (Samford 1996:107). In southeast Texas, the Levi Jordan Plantation finds include a group of seven silver coins (one perforated), all wrapped in a coarsely woven cloth and buried in a hole in the floor. This bundle of artifacts may have been a specific type of nkisi (Brown 1994:112). A brick with a cosmogram incised into it was found in the wall of one of the slave quarters at this plantation, providing further evidence that African Americans protected their buildings by placing ritualistic items in the walls of their houses (Brown 1994:110).

It appears that many types of containers housing a variety of different items have been interpreted as minkisi, and any combination of such artifacts could be identified as such. Archeologists working on slave sites should be aware of the existence of these types of religious artifacts and pay close attention to spatial relationships of possible religious artifacts. Perishable materials used to hold the components of a nkisi could deteriorate, for example, leaving only a cluster of nonperishable objects in the archeological record.

\section{AFRICAN AMERICAN ARTIFACTS AT FANTHORP}

The artifacts from Fanthorp Inn that may have been used in association with African American spiritual practices include 17 quartz crystals and 1 piece of milky quartz with small embedded crystals (an additional crystal is present in the collection but lacks provenience information and thus is not included here), a group of artifacts interpreted as a possible nkisi, and 2 marine shells. Fanthorp is located in Grimes County on the coastal plain of Texas over 80 miles from the Gulf of Mexico. Lithologic units in this area are terrigenous, clastic deposits which are not conducive to the formation of quartz crystals (Bureau of Economic Geology 1974; Karl Kibler, personal communication 1996). These types of deposits contain quartz, but only in small, rounded fragments in clastic sediments (i.e., fine to coarse sand). Angular quartz crystals do not occur naturally in the area (Karl Kibler, personal communication 1996), and the well-developed quartz crystals found at Fanthorp are definitely of nonlocal origin; human activity was responsible for these crystals being at the site.

Each of the quartz crystals has at least one welldefined natural point (i.e., an apex where three or more faces join) which is neither modified, worn, nor water rolled. All are colorless to slightly yellow with 
the exception of one crystal that has some black inclusions toward its base, and they range from 8 to 33 $\mathrm{mm}$ in length. Most are single crystals broken off at the base, but one is made up of two crystals joined at their bases, and two are double-pointed crystals (Figure 38).

Four of the pointed crystals and the milky quartz fragment with small crystals embedded in it were found in the trench that ran along the line of S246.5-248, between E262 and E286. This section of the trench starts at the northeast corner of the kitchen deposits and runs east for about $20 \mathrm{ft}$. One of these four crystals is smoky quartz with black inclusions. A seventeenth quartz crystal is mentioned in the 19781982 catalog, and this one was located northeast of the kitchen as well.

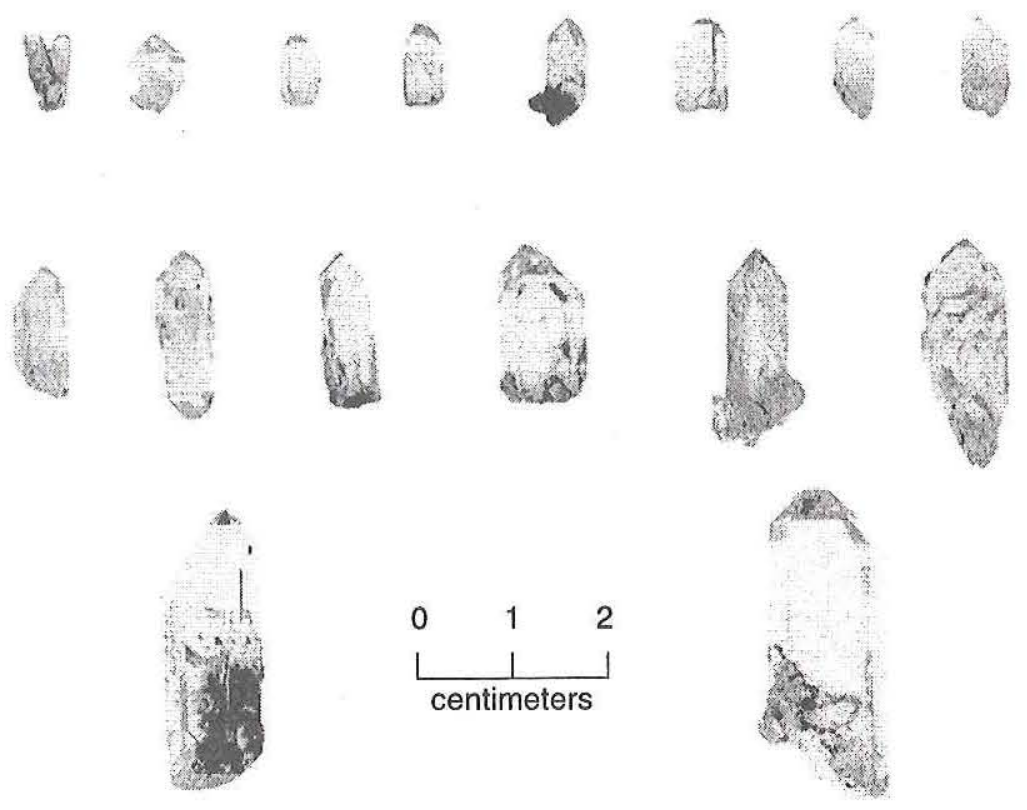

Figure 38. Sixteen of the 17 quartz crystals.

Eight crystals were recovered under the house. Four of these were found beneath Room 106 and four in the ground under the front gallery (Room 102). Room 106 was added in two stages. "The earliest configuration conformed to the width of the south log room (Room 103) and the depth of the rear gallery. Enlargement of the room to its present size was probably contemporary with, or later than, the addition of the dining-room ell" (TPWD 1983:II:55). Of those crystals from Room 106, three were found in the area under the second addition (probably constructed around 1850 or later) and only one was found under the first addition (likely constructed in the late 1830s).

Of the remaining five crystals, one was found in Cistern 2, one in the yard area between the kitchen and the dining ell, another on the north side of the house, and two in the yard west of the house.

Slaves probably had access to all or most areas of the inn and grounds of Fanthorp. The household slaves would have cooked in the kitchen and cleaned the entire house. Unfortunately, it is not possible to analyze artifacts from slave living quarters at the site, since they would have been located on property not owned by the state and hence were not excavated. By provenience alone, the quartz crystals found here cannot be attributed to any specific person or group of people. The argument for the association between the crystals and African Americans comes from a lack of theoretical association between crystals and other ethnic groups and the abundance of evidence from other African American sites. The only reasonable reason for white people at the site to have collected the crystals would have been the attractive qualities of the crystals; in their natural form, crystals were not commonly used by whites for any practical purposes. If Native American Indians were historically known to be part of the social makeup at Fanthorp, they could be suspected of bringing the crystals with them, but no mention of any Native Americans is made in any of the historical documents researched to date.

The possible nkisi found at the site consists of five major elements: four rectangular paper packets ranging from $9 \times 12 \mathrm{~mm}$ to $16 \times 30 \mathrm{~mm}$ wrapped in an undyed, woven cloth with the remains of bone evident (Figure 39). The material within the paper packets has not been chemically analyzed, but it appears to be either chalk or white clay as it is a white, fine-grained powder that produces a mark like chalk. Extremely small fragments of bone were also found in the bundle with the packets, indicating that other materials may have been part of the nkisi contents. The $8.5-\mathrm{x}-3-\mathrm{cm}$ bundle was found by the construction workers while they were dismantling the chimney at the north side of the house. It is possible that the chimney was constructed during the 1850 s when the second story was added to that part of the house (undoubtedly using slave labor), but the hearth and lower section of the chimney were probably not altered from their original construction. The date for the inclusion of the nkisi with the chimney could be as early as the 


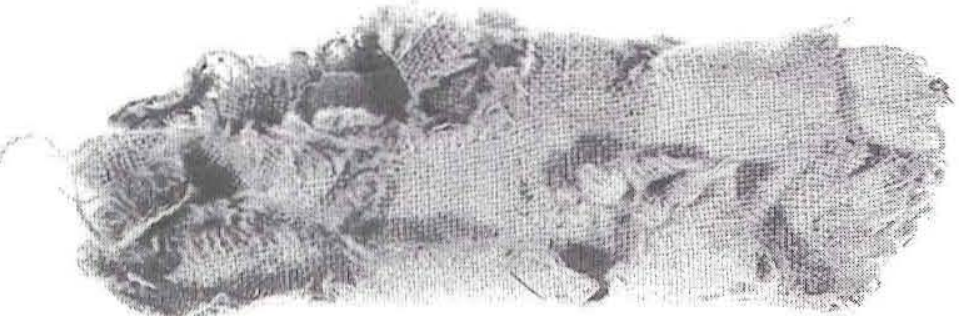

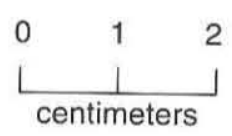

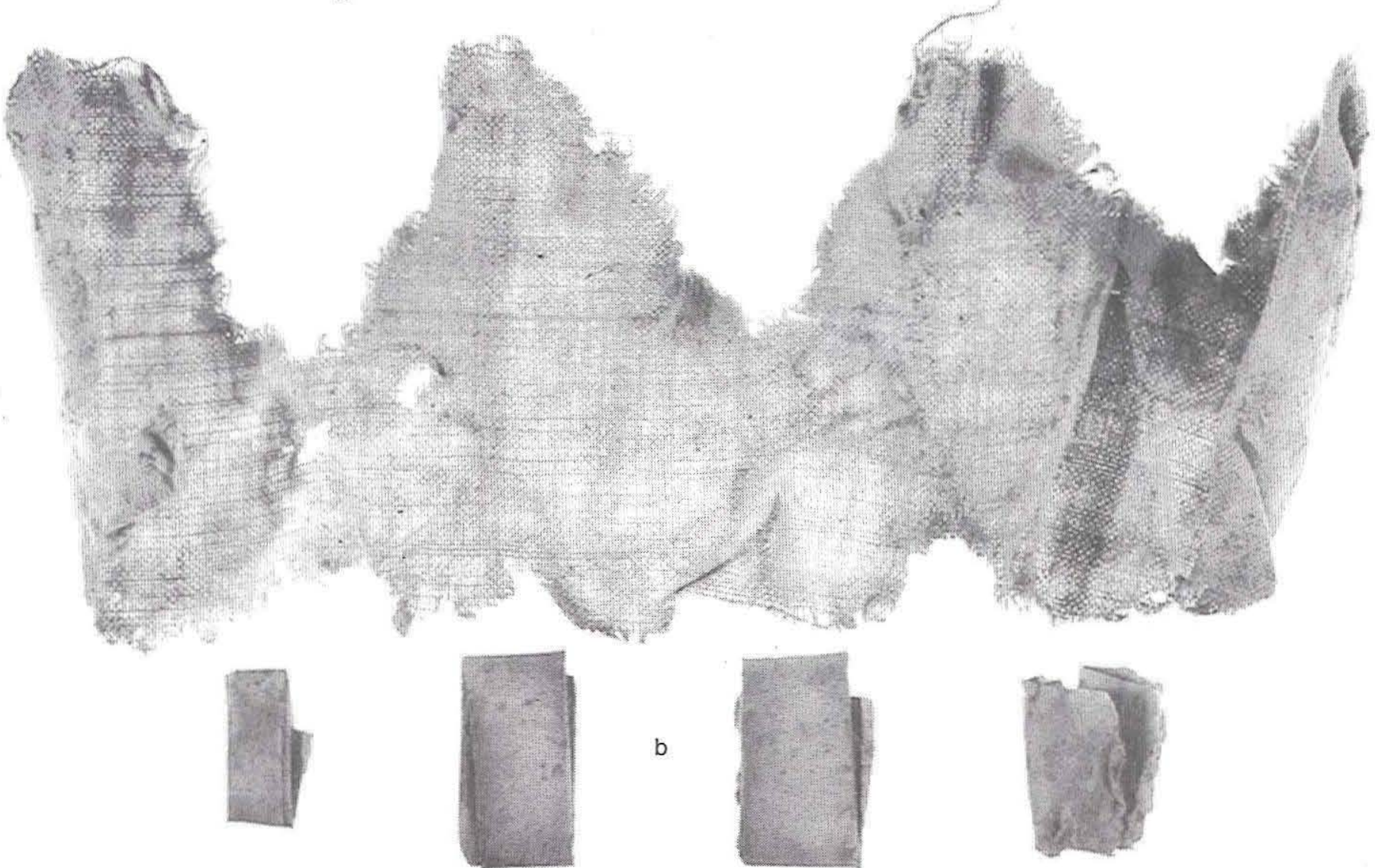

Figure 39. The possible nkisi. (a) As found; (b) opened with contents. 
construction of the house, or it could date much later. One end of the bundle had been knawed by rodents indicating that it had likely been placed between the stones of the chimney with one end exposed. Some minimal staining is seen on the other end of the bundle, and this may be smoke or water damage. Because of the minimal charring or smoke damage, it appears that this bundle was not placed in the stones of the interior hearth, but into the stones on the mantle area or the chimney on the exterior of the house.

One grouping of artifacts that may have been a nkisi was recovered from a chimney context at the Manassas Battlefield Park in Virginia (Galke 1992a:137), and as mentioned previously, minkisi have been found in the walls of at least two slave quarters in North Carolina and Virginia. However, the nkisi from Fanthorp is the only example known to this author to have been found in association with the owner's house. There is no evidence that slaves or freed blacks ever lived in the inn building although they did work there. Therefore, the nkisi may have been used either to protect the workers in the house or to benefit the owners of the slaves. There is historical evidence that the slaves at Fanthorp were treated well, as a quote from a letter to Elizabeth Beardsley from Jane Beardley in 1851 attests:

They have four Men, five Women \& four Children colored, besides overseer \& hostler, white. A happier set I never saw [than] these negroes are, there is an abundance of everything provided \& they fare just as well as the boarders, I scarcely ever step out on the dining room piazza without seeing one or two little negroes with roast beef, beef steak, Sweet Potatoes or something of the kind in hand \& grease from ear to ear. I suppose all the Slaves in Texas do not fare as well as Mr. Fanthorps. I am told they are better treated than in the old Southern States [J. Beardsley 1851a].

If the slaves at Fanthorp were protecting their owners with this nkisi, this may be the first known instance of this to be seen in the archeological record.

Two seashells, both very small, are in the Fanthorp collections. One is very weathered, and although it likely had markings, they are no longer visible. This shell belongs to the Conus species, which is common along the Gulf Coast and around the world (Abbott 1968:160-163; Dance 1992:185-194; Douglass 1989:38). This shell is white from weathering, $1.1 \mathrm{~cm}$ long, and perforated at the top of the cone and on the shoulder on either side of the cone; all three perforations are in line with each other. These perforations were most likely bored by a predator rather than hand drilled. Both vertical and horizontal structural ridges are seen on the shell, and a great deal of wear and polish are present. This shell was found in Level 2 of Unit 111-8, under the back porch. The other shell is a Virgin Nerite shell, which is found along the Gulf Coast and in other coastal localities. This tiny 7-mm-long shell has extremely intricate natural markings, which are aesthetically pleasing. No perforations or other alterations are present, but the edge along the mouth of the shell is broken. Both specimens are marine shells. Since Fanthorp is over 80 miles from the nearest salt water, it is clear that, like the crystals, the shells must have been brought to the site by humans. Shells, particularly cowrie, were often included in minkisi.

\section{INTERPRETATIONS}

The majority of slave owners in Texas either brought slaves with them to the territory or purchased slaves from other owners or traders. Although these slaves were mainly American born, and laws were put into place in 1807 to stop the trading of slaves from Africa, the slave trade from that continent, and therefore a direct African influence on the slave community, continued up to the time of the Civil War. In Texas, the African slave trade went underground during the 1830s and 1840s but was revived in the $1850 \mathrm{~s}$ as the demand for slaves increased (Silverthorne 1986:29). Evidence from both Fanthorp Inn and the Levi-Jordan Plantation indicates that even if the slaves were not born in Africa, an African influence was present in the actions of Texan slaves.

Evidence indicates the common use of quartz crystals by African American slaves at sites across the South, including Texas. The crystals were commonly used in the making of minkisi, but they were also found in contexts where they do not appear to have been used in this manner. At the Fanthorp site, there is not enough contextual evidence to interpret how the quartz crystals were used, whether in the making of minkisi, in divining practices, as personal protection from evil spirits, or as attractors for good spirits. The most convincing explanation for the presence of the artifact bundle found in the chimney rubble is that it was a nkisi made by the African American slaves, possibly the same ones who helped build the chimney, based on the contents of the bundle, its location within the walls of the chimney, and evidence of similar placements of minkisi at other sites. The evidence from this site indicates that African American slaves 
and freedmen employees at Fanthorp Inn were active members of the inn community, that they had a visible impact on the archeological record in and around the inn building, and that they probably had a strong religious tradition that was reminiscent of African belief systems. 


\section{SUMMARY AND CONCLUSIONS}

\begin{abstract}
SUMMARY
Fanthorp Inn State Historical Park in Anderson, Grimes County, Texas, presents the inn as it appeared during the mid-nineteenth century. During the years since the first occupation of the land in the 1830 s, the building has served both as an inn and as a private residence. The inn itself was operated from the late 1830s until the death of Henry and Rachel Fanthorp in 1867, after which it was used as a residence by Mary Fanthorp Stone until her death in 1901, and then by Judge James G. McDonald from 1901 until he was committed to the Austin State Hospital in 1935. Aside from occasional use, the building was abandoned until 1945 when Julia Yarborough DeSaussure (Mary Fanthorp Stone's daughter) moved back to her childhood home where she remained until her death in 1976. The site was conveyed to the State of Texas in 1977.

To prepare the site as a park, the inn building needed renovations, including installation of modern utilities, restoration to its mid-nineteenth-century appearance, and reinforcement of its foundations. Archeology was carried out to collect data from those deposits that would be affected by the renovations. Archeological techniques were also used to search for other building remains within the park boundaries.

The first archeological investigations in 1978 explored four areas, including the proposed parking lot, land just north of the inn, an artifact scatter east of the inn, and a circular depression south of the inn that would later be named Cistern 2. The 1982 investigations focused on several areas, including a piece of land southwest of the inn where a stable once stood, the area north of the inn, and the kitchen remains. The 1978 and 1982 seasons are summarized in reports by Burnett (1981) and Ing and Hart (1987).

This report summarizes work conducted in field seasons from 1983 to 1989. Excavated during these seasons were areas throughout the property, including parts of most of the yard areas, under the porches, and some limited excavations under the house. The
\end{abstract}

objectives of this report are to provide a description of the work performed in these seasons, to inventory the artifacts excavated, and to analyze in detail selected artifacts from these seasons.

In total, 119,561 artifacts were excavated during these later field seasons. The largest portions of these are the unknown, architecture, and domestic groups, making up 38,31 , and 28 percent, respectively. The personal and domestic groups make up only 2 and 1 percent of the assemblage. The transportation, group services, and group ritual groups make up insubstantial portions of the assemblage. Artifact classes chosen for analysis include bottles and jars, pressed glass, other tableware glass, lamp chimney rim sherds, flaked glass, transfer-printed ceramics, marked ceramics, smoking pipes, marked spoons, coins, arms and ammunition, dolls, and marbles. Artifacts believed to be associated with African American religious practices were also analyzed. In general, the assemblage at Fanthorp presents what would be expected of a nineteenth- and twentieth-century site in southeastern Texas.

\section{CONCLUSIONS}

One of the goals of this research was to analyze the artifacts in relation to the occupation periods of different residents at the site. Three main periods were identified: the inn period from 1834 to 1867 , the Mary Fanthorp Stone period from 1867 to 1901, and the Judge McDonald period from 1901 to 1935 .

The transfer-printed ceramics best represent the inn period of the early to middle nineteenth century. As would be expected of any North American ceramics collection of this time period, all but one of the transfer-print patterns are from England; 12 of these are definitely from the Staffordshire area. The David Johnston mark was found, through the aid of the Victoria and Albert Museum's Assistant Curator, R. J. C. Hildyard, to be made by David Johnston of Bordeaux, France, from 1830 to 1844 (Tardy 1979:200-201), placing these pieces in the inn period. 
This type of transfer-printed earthenware was almost always imported from England, so to have a pattern that is French is unusual. Although it is believed that a great deal of the deposits on top of the kitchen ruin were brought in, it is almost certain that these pieces were deposited while the kitchen was in use. The distribution pattern suggests either a door or window in the central south wall of the kitchen as suggested by Black (see Figure II-2 in Ing and Hart 1987:250).

Many transfer-print patterns in many colors were found in the Fanthorp deposits. Several of these patterns occur on multiple pieces, but few of the patterns from this period are seen on more than one vessel type, and those that are tend to date to the late nineteenth century. This could be due to the small sherds and the difficulty in identifying vessels, or it could be because the patterns were not bought in sets in the mid-nineteenth century. This may represent a local phenomenon whereby the use of sets that had emerged in the Northeast by the 1780s (Deetz 1977:60) may not have occurred in the Southwest until the middle to late nineteenth century. Supporting this theory are the collections from the townsite of Velasco in Brazoria County. At this site, 82 identifiable transfer-print patterns from the early and middle nineteenth century were identified, and of these only 16 patterns are represented by more than one identifiable vessel type (Earls et al. 1996:178-183) indicating that sets were not well represented in the archeological record.

The archeological evidence from the 1982 excavations indicates that the transportation of goods appears to have relied on ocean and river routes into the area and then overland from the nearest port instead of entirely overland from the East. This is assumed because of the similarities of the transferprint patterns between Washington-on-the-Brazos and Fanthorp Inn (Ing and Hart 1987:254). Similar patterns found at Velasco also indicate this pattern of trade (Earls et al. 1996:156-161). Although the stagecoach was a common means of transportation for both long and short overland trips for people and mail, it was more common for shipments of goods to come by boat into coastal or river ports. Railroads were the first means of overland transportation that started to truly compete for the shipping business. The first train into Grimes County was in 1859 when the Houston and Texas Central line extended to Navasota (Texas State Historical Association 1996:344). This line made it easier to get goods from the port into the interior and may have reduced the river trade in the area, but the more general transportation of goods from the Eastern ports would still have been by ship. It was not until the big push for transcontinental railroads later in the century that railroads started to take over the east-west trade in the country from the water routes.

The period of 1867 to 1901 when Mary Fanthorp Stone lived at Fanthorp continues to be a bit of a puzzle with no analyzed artifacts dating solely to this time. Grimes County in the years following the Civil War was economically depressed. The epidemics of cholera and yellow fever that killed both Henry and Rachel Fanthorp killed hundreds in the county and hampered recovery from the defeat (Texas State Historical Association 1996:344). A time of violence and racial unrest was just starting that would last for many decades. Farms were reduced in value to a third of that before the war. It took until 1910 for the Grimes County farms to regain their 1860 value (Texas State Historical Association 1996:345). Livestock production suffered, and the number of animals in the county was reduced by one-half between 1860 and 1870. Corn and cotton were the main crops that continued to be grown in the county, and after a couple of decades they had regained their value (Texas State Historical Association 1996:345). The depression suffered by Anderson residents could be the reason for a lack of artifacts from this period with a need to reuse and highly curate material goods.

The archeology at Fanthorp Inn ties in well with the history of the site and its occupants and the county itself during the early-twentieth-century occupation of Judge McDonald. From the end of the Civil War, the county was struggling with racial unrest. A large population of slaves $(5,468$ in 1860 compared to 4,852 whites) suddenly became a large population of freed African Americans (Texas State Historical Association 1996:344). This large population of African Americans was seen as a threat toward which the whites in the county rebelled. A period of lawlessness followed with considerable violence, particularly whites against African Americans, for which few offenders were ever prosecuted. Twelve homicides were reported in 1867 alone (Texas State Historical Association 1996:344). The Ku Klux Klan was established in the county in 1868 , and in defense, black militias were created. James G. McDonald organized a meeting to found the Grimes County White Man's Union, a group created by Grimes County Democrats to counter the sweeping victories of the People's Party in the county elections of 1896 and 1898. In 1900, he was accused of killing Jim Kennard, a black district clerk, although he was never prosecuted for the crime due to public sentiment. Kennard was the last name of McDonald's mother-inlaw, indicating that Jim was likely either a freed slave of the Kennards or a descendant thereof. 
The lawlessness in the county at this time is well documented in the historic record, and the archeological record at Fanthorp Inn supports this history. Six hundred eighty-nine gun-related artifacts are in the assemblage of 119,561 artifacts. This is a large number when compared to similar sites such as Sebastopol in Seguin, Texas, which is of approximately the same time period. At this site, where 106,586 artifacts were excavated, only 289 of them are gun related, less than half the number found at Fanthorp (Sauer and Brandimarte 1997). The large number of cartridges, and the revolver rounds in particular, indicate that nonhunting activities occurred at the site. Although some of the rifle cartridges could be a result of hunting, it is likely that the revolver rounds were used in preparation for defensive or offensive endeavors. Target shooting or simply setting rounds off into the air were likely common practices by McDonald and his friends. A minimum of 22 different types of breechloading guns are represented by ammunition and gun parts, and at least half of these were revolvers. This means that if more than one gun using the same type of ammunition was used at the site, the number of guns could very well have been much higher. All but 10 of the 215 cartridges could date to the period when Judge McDonald lived at the house.

The African Americans supported the party of their emancipator, Lincoln, and the large population of African Americans in the county, which had grown to almost 60 percent by 1870 , created a Republican stronghold. From 1872 until 1900, in only one presidential election did the county favor a Democratic nominee (Texas State Historical Association 1996:345).

After smashing victories by the People's party [a new party made up of mostly black former Republicans] in the county elections of 1896 and 1898, Grimes County Democrats [including Judge McDonald] retaliated by forming the White Man's Union, an initially secret, oath-bound society designed to end electoral "corruption" by excluding blacks from participation in county politics. The White Man's Union launched a campaign of night-riding and intimidation of Populist voters and orchestrated the murder of several black Populist leaders. . . . With terrorized Populists avoiding the polls, the White Man's Union swept the elections of
1900, and blacks began a mass migration from the county. The White Man's Union proceeded to select every officer of the county government until 1958. . . B Black migration [from the county] resumed during the Great Depression ... . and then accelerated during the 1940s. . . . Blacks continued to leave Grimes County throughout the post-World War II period, until by 1990 only 3,988 remained-23 percent of the total population [Texas State Historical Association 1996:345-346].

The electoral button found for Democrat Judson Harmon reinforces the Democratic preference of Judge McDonald's household.

Texas is often looked upon as a geographic and social area in and unto itself. It is not quite the "West" or the "South" and is often ignored in studies of the social history of these areas. The history and archeology of the Fanthorp site indicate that, at least in Grimes County, the Southern social and racial traditions were strong. From its beginnings, this area of East Texas adopted the Southern pattern of plantation agriculture (Texas State Historical Association 1996:344), and through the twentieth century, it has reflected the type of racial tensions seen throughout the South.

It is theorized that the slaves who lived at Fanthorp had spiritual and physical practices that varied from those of their owners. They seem to have used a nkisi (charm) to protect the inn building, either wishing to protect the slaves working in the house or their owners living there from bad spirits or to attract good ones. They also probably used crystals for similar goals. Pits in both the kitchen and the cellar may have been used as storage pits by the slaves, as these types of features are often found at slave sites. The slaves had an impact on the archeological record that is not yet fully understood, and further research on such sites in this area concentrating on slave quarters would be beneficial in the study of slavery in eastern Texas.

The archeology at Fanthorp Inn can be seen as reflecting the social climate in Grimes County throughout its history. It also illuminates aspects of life at Fanthorp Inn that have not traditionally been studied, including the influence of violence and guns and the use of specific spiritual practices by African Americans. Archeology at the site has provided new information that broadens our view of the Fanthorp family and their lives at the inn. 



\section{REFERENCES CITED}

Abbott, R. Tucker

1968 A Guide to Field Identification: Seashells of North America. Golden Press, New York.

Alho, Olli
1980

1980 The Religion of the Slaves: A Study of the Religious Tradition and Behaviour of Plantation Slaves in the United States 1830 1865. Soumalainen Tiedeakatemia, Academia Scientiarum Fennica, Helsinki.

Allen, Irene Taylor

1957 Saga of Anderson: The Proud Story of a Historic Texas Community. Greenwich Book Publishers, New York.

American Medical Association

1912 Nostrums and Quackery: Articles on the Nostrum Evil and Quackery Reprinted, with Additions and Modifications, from The Journal of the American Medical Association. 2nd ed. American Medical Association Press, Chicago.

Armstrong, David, and Elizabeth Metzger Armstrong

1991 The Great American Medicine Show: Being an Illustrated History of Hucksters, Healers, Health Evangelists and Heroes from Plymouth Rock to the Present. Prentice Hall, New York.

Assad, Cristi

1987 Appendix I: Analysis of the Fanthorp Inn State Historic Site (41GM79) Vertebrate Faunal Remains. In Archeological Excavations at Fanthorp Inn State Historic Site (41GM79), Grimes County, Texas, 1982, by J. David Ing and John Hart, pp. 235-247. Texas Parks and Wildlife Department, Austin.

Bamunoba, Y. K.

1979 La Conception de la Mort dans la Vie Africaine. In La Mort dans la Vie Africaine, by Y. K. Bamunoba and B. Adoukonou. Unesco, Paris.

Barnes, Frank C.

1993 Cartridges of the World. DBI Books Inc., Northfield, Illinois.
Beardsley, Abel S

1850 Letter from Abel S. Beardsley to Amos Beardsley, December 15, 1850. Abel Smalton Beardsley Papers, Center for American History, The University of Texas at Austin.

1851a Letter from Abel S. Beardsley to Jane Beardsley, April 24, 1851. Abel Smalton Beardsley Papers, Center for American History, The University of Texas at Austin.

1851b Letter from Abel S. Beardsley to Elizabeth Beardsley, February 20, 1851. Abel Smalton Beardsley Papers, Center for American History, The University of Texas at Austin.

1851c Letter from Abel S. Beardsley to Jane Beardsley, February 26, 1851. Abel Smalton Beardsley Papers, Center for American History, The University of Texas at Austin.

1853 Letter from Abel S. Beardsley to Elizabeth Beardsley, November 8, 1853. Abel Smalton Beardsley Papers, Center for American History, The University of Texas at Austin.

1854a Letter from Abel S. Beardsley to Elizabeth Beardsley, June 19, 1854. Abel Smalton Beardsley Papers, Center for American History, The University of Texas at Austin.

1854b Letter from Abel S. Beardsley to Elizabeth Beardsley, September 25, 1854. Abel Smalton Beardsley Papers, Center for American History, The University of Texas at Austin.

Beardsley, Jane

1851a Letter from Jane Beardsley to Elizabeth Beardsley, October 17, 1851. Abel Smalton Beardsley Papers, Center for American History, The University of Texas at Austin.

1851b Letter from Jane Beardsley to Elizabeth Beardsley, December 14, 1851. Abel Smalton Beardsley Papers, Center for American History, The University of Texas at Austin. 
Black, J. S.

1834 Letter from J. S. Black to S. C. Robertson, January 29, 1834. Sterling C. Robertson Papers, University of Texas at Arlington.

Blair, Eric L.

1930 Early History of Grimes County. N.p., n.p.

Blassingame, John W.

1976 Status and Social Structure in the Slave Community. In Perspectives and Irony in American Slavery, edited by Harry P. Owens. University Press of Mississippi, Jackson.

Boulet, Joseph Eugene

n.d. "Baptist Churches in Grimes County." Center for American History, The University of Texas at Austin.

Brantley, William F.

1975 A Collector's Guide to Ball Jars. Rosemary Humbert Martin, Publisher, Muncie, Indiana.

Brown, Kenneth L.

1994 Material Culture and Community Structure: The Slave and Tenant Community at Levi Jordan's Plantation, 1848-1892. In Working Toward Freedom: Slave Society and Domestic Economy in the American South, edited by Larry E. Hudson, Jr. University of Rochester Press, Rochester, New York.

Brown, Kenneth L., and Doreen C. Cooper

1990 Structural Continuity in an African-American Slave and Tenant Community. In Historical Archaeology on Southern Plantations and Farms, edited by Charles E. Orser, Jr. Historical Archaeology 24:7-19.

Buffington, Alice and Edward Anderson

1979 Alice and Edward Anderson Buffington to Peter Flagg Maxon, April 27 and August 23, 1979. Interview on file, Texas Parks and Wildlife Department, Cultural Resources Program, Austin.

Buffington Family Papers

Collection of Mr. and Mrs. Edward Buffington, Anderson, Texas.

Bureau of Economic Geology

1974 Geologic Atlas of Texas, Austin Sheet. Bureau of Economic Geology, The University of Texas at Austin.

Burnett, R. E.

1981 Archeological Testing, Fanthorp Inn State Historic Site, 41GM79, Grimes County, Texas. Texas Parks and Wildlife Department, Historic Sites and Restoration Branch, Austin.
Carter, James David

1955 Education and Masonry in Texas to 1846. Grand Lodge of Texas, Waco.

Central Texian (Anderson)

Coleman, D. S., E. A. Coleman, and E. J. Coleman 1968 The Collector's Encyclopedia of Dolls. Crown Publishers, New York.

Connor, Seymor V.

1971 Texas: A History. Thomas Y. Crowell Co., Inc., New York.

Coysh, A. W., and R. K. Henrywood

1982 The Dictionary of Blue and White Printed Pottery 1780-1880, Volume 1. The Antique Collectors' Club Ltd., Woodbridge, Suffolk.

Daily Examiner, The (Navasota)

Dance, S. Peter

1992 The Eyewitness Handbook of Shells. Dorling Kindersley, Inc., New York.

Daniel, Joseph

1845 Letter from Joseph Daniel to Mitchell, January 30, 1845. Post Office Papers, Texas State Archives, Austin.

Day, James M. (editor and compiler)

1966 Post Office Papers of the Republic of Texas, 1836-1840. Texas State Library, Austin.

1967 Post Office Papers of the Republic of Texas, 1839-1840. Texas State Library, Austin.

DeBolt, C. Gerald

1988 The Dictionary of American Pottery Marks, Whiteware and Porcelain. Charles E. Tuttle Company, Rutland, Vermont.

De Cordova, Jacob

1858 Texas: Her Resources and Her Public Men. Reprinted 1969. Texas Press, Waco.

Deetz, James

1977 In Small Things Forgotten: The Archeology of Early American Life. Anchor Books, New York.

Deschamps, Hubert

1970 Les Religions de L'Afrique Noire. Presses Universitaires de France, Paris.

Douglass, Jackie Leatherbury

1989 Peterson First Guide to Shells of North America. Houghton Mifflin Company, Boston. 
Earls, Amy C., Terri L. Myers, Brian S. Shaffer, Karl W. Kibler, Karen M. Gardner, Laurie S. Zimmerman, Elton R. Prewitt, and Sandra L. Hannum

1996 Testing and Data Recovery at the Townsite of Old Velasco (41BO125), Brazoria County, Texas. Reports of Investigations No. 94. Prewitt and Associates, Inc., Austin, Texas.

Fagan, Brian

1995 Time Detectives. Simon and Schuster, New York.

Fanthorp Family Cemetery

Inscriptions. Anderson, Texas.

Fanthorp, Henry

1837 Letter from Henry Fanthorp to Postmaster General, July 1, 1837. Buffington Family Papers, Collection of Mr. and Mrs. Edward Buffington, Anderson, Texas.

1839 Letter from Henry Fanthorp to M. B. Lamar, November 4, 1839. Mirabeau B. Lamar Papers, Texas State Archives, Austin.

Fanthorp Inn Records

Center for American History, The University of Texas at Austin.

Fanthorp, John H.

1857 Ms. by John H. Fanthorp, March 11, 1857. Buffington Family Papers, Collection of Mr. and Mrs. Edward Buffington, Anderson, Texas.

Ferguson, Leland

1992 Uncommon Ground: Archaeology and Early African America, 1650-1800. Smithsonian Institution Press, Washington.

Fike, Richard E.

1987 The Bottle Book: A Comprehensive Guide to Historic, Embossed Medicine Bottles. Gibbs M. Smith, Inc., Salt Lake City, Utah.

Flayderman, Norm

1980 Flayderman's Guide to Antique American Firearms ... and their values. DBI Books, Inc., Northfield, Illinois.

Foulke, Jan

1995 Insider's Guide to China Doll Collecting. Hobby House Press, Inc., Grantsville, Maryland.

Frazier, E. F.

1964 The Negro Church in America. Schocken, New York.

Galke, Laura

1992a Cultural Resource Survey and Inventory of a War-Torn Landscape: The Stuart's Hill Tract, Manassas National Battlefield Park, Virginia.
Manassas National Battlefield Park, Virginia.

1992b You Are Where You Live: A Comparison of "Africanisms" at Two Sites at Manassas Battlefield Park. Lecture presented at the National Park Service: National Capital Region African American History Month.

Gammel, H. P. N.

1898 The Laws of Texas. 10 vols. Austin, Texas.

Garber, Alice Y

1954 Letter from Alice Y. Garber to Texas State Historical Survey Committee, June 29, 1954. Buffington Family Papers, Collection of Mr. and Mrs. Edward Buffington, Anderson, Texas.

Garwood, Ellen

1956 Early Texas Inns: A Study in Social Relationships. Southwestern Historical Quarterly LX (October, 1956):219-244.

Gates, William C., Jr., and Dana E. Ormerod

1982 The East Liverpool, Ohio, Pottery District: Identification of Manufacturers and Marks. Historical Archaeology 16(1-2).

Genovese, Eugene D.

1976 Roll, Jordan, Roll: The World the Slaves Made. Vintage Books, New York.

Georgia Writers' Project

1940 Drums and Shadows: Survival Studies among the Georgia Coastal Negroes. University of Georgia Press, Athens.

Gillette, Charles

1851 Letter from Mary Wharton Gillette to Charles Gillette, December 16, 1851. Charles Gillette Papers, Archives of the Episcopal Church, Episcopal Theological Seminary of the Southwest, Austin, Texas.

Gillette, Charles, Papers

Archives of the Episcopal Church, Episcopal Theological Seminary of the Southwest, Austin, Texas.

Godden, Geoffrey A.

1991 Encyclopaedia of British Pottery and Porcelain Marks. Barrie \& Jenkins, London.

Goodwyn, Lawrence C.

1971 Populist Dreams and Negro Rights: East Texas as a Case Study. American Historical Review 76 (December 1971):1435-1456.

Greer, Georgeanna H.

1981 American Stonewares: The Art and Craft of Utilitarian Potters. Schiffer Publishing, Ltd., Exton, Pennsylvania. 


\author{
Grimes County \\ Deed Records \\ Maps and Plats, "Plan of the Town of Alta Mira," \\ November 3, 1846 \\ Marks and Brands Book \\ Marriage Records \\ Probate Records \\ Grist, Everett \\ 1995 Everett Grist's Big Book of Marbles. Collector \\ Books, Paducah, Kentucky. \\ Henry, S. L., and P. H. Garrow \\ 1982 Appendix H: Ceramic Type Descriptions. In City \\ of Phoenix: Archaeology of the Original \\ Townsite, Blocks 1 and 2, edited by J. S. Cable, \\ S. L. Henry, and D. E. Doyel, pp. 465-472. Soil \\ Systems Publications in Archaeology No. 1.
}

Herskovits, M. J.

1958 The Myth of the Negro Past. Beacon, Boston.

Hogan, William R.

1969 The Texas Republic: A Social and Economic History. University of Texas Press, Austin.

Howell, William Randolph

1861 "Journal of a Soldier of the Confederate States Army," May 1, 1861. William Randolph Howell Papers, Center for American History, The University of Texas at Austin.

1864 "Louisiana Campaign, 1864," August 20, 1864. William Randolph Howell Papers, Center for American History, The University of Texas at Austin.

Humphrey, Richard V.

1969 Clay Pipes from Old Sacramento. Historical Archaeology 3:12-33.

Hunt, William J., Jr.

1995 Embossed Medicine Bottle Labels Finding Aid. Program on WordPerfect available through the National Parks Service, Midwest Archeological Center, Lincoln, Nebraska.

Ing, J. David, and John Hart

1987 Archeological Excavations at Fanthorp Inn State Historic Site (41GM79), Grimes County, Texas, 1982. Texas Parks and Wildlife Department, Historic Sites and Restoration Branch, Austin.

Jenks, Bill, Jerry Luna, and Darryl Reilly

1993 Identifying Pattern Glass Reproductions. Wallace-Homestead Book Company, Radnor, Pennsylvania.

Johnson, Frank W.

1914 A History of Texas and Texans. Vol. IV.
American Historical Society, Chicago.

Jones, Anson

1859 Memoranda and Official Correspondence Relating to the Republic of Texas, Its History and Annexation, Including a Brief Autobiography of the Author. Reprinted 1966. Rio Grande Press, Chicago.

Jones, Lynn Diekman

1995 The Material Culture of Slavery from an Annapolis Household. Paper presented at the Society for Historical Archaeology Annual Meeting, Washington, D.C., January 4-8, 1995.

Jones, Olive

1971 Glass Bottle Push-ups and Pontil Marks. Historical Archaeology 5:62-73.

1986 Cylindrical English Wine and Beer Bottles, 17351850. Studies in Archaeology, Architecture and History. National Historic Parks and Sites Branch, Environment Canada - Parks. Minister of the Environment, Ottawa.

Jones, Olive, and Catherine Sullivan

1989 The Parks Canada Glass Glossary for the Description of Containers, Tableware, Flat Glass, and Closures. National Historic Parks and Sites Branch, Canadian Parks Service, Ottawa.

Joyner, Charles

1989 Remember Me: Slave Life in Coastal Georgia. Georgia Humanities Council, Atlanta, Georgia.

Kennard, Sarah

1860 Letter from Sarah Kennard to A. D. Kennard, Jr., February 21, 1860. Kennard Genealogy, Marcus Mallard Papers, in originator's possession, Navasota, Texas.

Klingelhofer, Eric

1987 Aspects of Early Afro-American Material Culture: Artifacts from the Slave Quarters at Garrison Plantation, Maryland. Historical Archaeology 21(2):112-119.

Kovel, Ralph, and Terry Kovel

1986 Kovels' New Dictionary of Marks: Pottery and Porcelain, 1850 to the Present. Crown Publishers, Inc., New York.

Lawrance, James W., Papers

Center for American History, The University of Texas at Austin.

Lehner, Lois

1988 Lehner's Encyclopedia of U.S. Marks on Pottery, Porcelain, and Clay. Collector Books, Paducah, Kentucky. 
Logan, George C.

1992 Archaeology at Charles Carroll's House and Garden and of his African-American Slaves. Pamphlet put out by Archaeology in Annapolis, Annapolis, Maryland.

Logan, George C., Thomas W. Bodor, Lunn D. Jones, Marian C. Creveling

19921991 Archaeological Excavations at the Charles Carroll House in Annapolis, Maryland, 18AP45. Report prepared for Charles Carroll House of Annapolis Inc. Archaeology in Annapolis, Annapolis, Maryland.

MacGaffey, Wyatt

1991 Art and Healing of the Bakongo Commented by Themselves: Minkisi from the Laman Collection. Folkens Museum-Ethnografiska, Stockholm.

Majewski, Teresita, and Michael J. O'Brien

1987 The Use and Misuse of Nineteenth-Century English and American Ceramics in Archaeological Analysis. Advances in Archaeological Method and Theory, Vol. 11, edited by Michael B. Schiffer, pp. 97-209. Academic Press, Inc., New York.

Mallard, Marcus, Papers

In originator's possession, Navasota, Texas.

McDonald, James Brown

1979 James Brown McDonald to Peter Flagg Maxson, August 23, 1979. Interview on file, Texas Parks and Wildlife Department, Cultural Resources Program, Austin.

McDonald, J. G.

n.d. "History of Grimes County." Clipping, Marcus Mallard Collection, Navasota, Texas.

McKearin, Helen, and Kenneth M. Wilson

1978 American Bottles and Flasks and Their Ancestry. Crown Publishers, Inc., New York.

Miller, George L., and Catherine Sullivan

1991 Machine-Made Glass Containers and the End of Production for Mouth-Blown Bottles. In Approaches to Material Culture Research for Historical Archaeologists, compiled by George L. Miller, Olive R. Jones, Lester A. Ross, and Teresita Majewski, pp. 99-112. The Society for Historical Archaeology, California, Pennsylvania.

Mintz, Sidney, and Richard Price

1976 An Anthropological Approach to the AfroAmerican Past. Philadelphia.

Montgomery County Historical Commission

n.d. Men from Montgomery County Texas who Served in the Confederate Army 1861-1864. On file,
Montgomery County Public Library, Conroe, Texas.

Montgomery, Robin Navarro

1975 The History of Montgomery County. Jenkins Publishing Co., Austin.

Munsey, Cecil

1970 The Illustrated Guide to Collecting Bottles. Hawthorn Books, Inc., New York.

Murray, Honorable Amelia M.

1856 Letters from the United States, Cuba and Canada. New York.

Navasota Examiner

Neblett, Lizzie Scott, Papers

Center for American History, The University of Texas at Austin.

Oberkamp, A. Anderson

n.d. Typescript entitled "Fanthorp Tavern" in Grimes County Scrapbook. Center for American History, The University of Texas at Austin.

Orser, Charles E. Jr.

1994 The Archaeology of African-American Slave Religion in the Anebellum South. Cambridge Archaeoloigcal Journal 4:1.

Patten, Drake

1992 Mankala and Minkisi: Possible Evidence of African American Folk Beliefs and Practices. African American Archaeology Newsletter 6.

Pollan, Sandra D, W. Sue Gross, Amy C. Earls, Johnney T. Pollan, Jr., and James L. Smith.

1996 Nineteenth-Century Transfer-Printed Ceramics from the Townsite of Old Velasco (41BO125) Brazoria Country, Texas: An Illustrated Catalogue. Prewitt and Associates, Inc., Austin.

Pool, Juliann C.

1987 Appendix V: Fanthorp Inn: A Study of Nineteenth and Twentieth Century Buttons. In Archeological Excavations at Fanthorp Inn State Historic Site (41GM79), Grimes County, Texas, 1982, by J. David Ing and John Hart, pp. 277-293. Texas Parks and Wildlife Department, Historic Sites and Restoration Branch, Austin.

Postmaster General

1844 Letter from Postmaster General to Anson Jones, Secretary of Texas, May 25, 1844. Post Office Papers, Texas State Archives, Austin.

Randall, Mark E.

1979 Marbles as Historical Artifacts. Marble Collectors Society of America. Trumbull, Connecticut. 
Ratcliff, John Noble, Jr.

1979 John Noble Ratcliff, Jr., to Peter Flagg Maxson, July 17, 1979. Interview on file, Texas Parks and Wildlife Department, Cultural Resources Program, Austin.

Richardson, T. C.

1940 East Texas: Its History and Its Makers. 3 vols. Lewis Historical Publishing Co., New York.

\section{Robertson, S. C.}

1834 Letter from S. C. Robertson to Henry Phanthorp [sic], January 21, 1834. Buffington Family Papers, Collection of Mr. and Mrs. Edward Buffington, Anderson, Texas.

Rochelle, Julia

1936 Story of Once Famous Fanthrope [sic] Tavern of 1834. Grimes County Reporter, February 27, 1936. Lizzic Scott Neblett Papers, Center for American History, The University of Texas at Austin.

Russell, Aaron E.

1996 Material Culture and African-American Spirituality at the Hermitage. Ms. on file with the author.

Russell and Erwin

1865 Illustrated Catalogue of American Hardware of the Russell and Erwin Manufacturing Company. Unabridged reprint, 1980. The Association for Preservation Technology, Baltimore, Maryland.

Samford, Patricia

1996 The Archaeology of African-American Slavery and Material Culture. The William and Mary Quarterly, 3d Series, Vol. LIII, No. I, January 1996.

Sauer, Sandra R.

1997 Sebastapol State Historical Park (41GU9), Seguin, Texas: Archeological Excavations, 19781988. Reports of Investigations No. 111 (draft). Prewitt and Associates, Inc., Austin.

Scott, Hattie

1856 Letter from Hattie Scott to Lizzie Scott Neblett, February 12, 1856. Lizzie Scott Neblett Papers, Center for American History, The University of Texas at Austin.

Silverthorne, Elizabeth

1986 Plantation Life in Texas. Texas A\&M University Press, College Station, Texas.

Singleton, Theresa A.

1988 An Archaeological Framework for Slavery and Emancipation, 1740-1880. The Recovery of Meaning: Historical Archaeology in the Eastern United States, edited by Mark P. Leone and
Parker B. Potter, Jr., pp. 345-370. Smithsonian Institution Press, Washington, D.C.

1996 The Archaeology of Slave Life. In Images of the Recent Past: Reading in Historical Archaeology, edited by Charles E. Orser, Jr., pp. 141-165. Alta Mira Press, Walnut Creek, California.

Spillman, Jane Shadel

1983 The Knopf Collector's Guide to American Antiques: Glass. Alfred A. Knopf, New York.

Sprague, Roderick

1981 A Functional Classification for Artifacts from 19th and 20th Century Historical Sites. North American Archaeologist 2(3).

Stampp, Kenneth M.

1956 The Peculiar Institution: Slavery in the AnteBellum South. Vintage Books, New York.

Tardy

1979 Les Poteries et les Faiences Françaises. Abancourt à Menotey, Paris.

Telegraph and Texas Register (Columbia)

Texas Baptist (Anderson)

Texas. Comptroller of Public Accounts Ad Valorem Tax Records, Grimes County. Texas State Archives, Austin.

Ad Valorem Tax Records, Montgomery County. Texas State Archives, Austin.

Texas. General Land Office (Austin)

Headright and Bounty Land Grants

Texas Parks and Wildlife Department (TPWD)

1983 Preservation Plan and Program for Fanthorp Inn State Historic Site Anderson, Texas. 2 vols. Texas Parks and Wildlife Department, Historic Sites and Restoration Branch, Austin.

Texas. Secretary of State

1848 Bond made by Henry Fanthorp et al. for county seat dontation, January 4, 1848. Bonds and Oaths, Secretary of State Papers, Texas State Archives, Austin.

Texas State Historical Association

1996 The New Handbook of Texas. Vol. 3. Texas State Historical Association, Austin.

Texas State Gazette (Austin)

Texas State Library and Archives (Austin)

Confederate Muster Rolls

Confederate Pension Rolls 
Texas National Register (Washington)

Texas Treasury Department

Public Debt Papers. Claims against the Republic Settled after 1845. Texas State Archives, Austin.

Thompson, Robert Farris

1983 Flash of the Spirit: African \& Afro-American Art \& Philosophy. Vintage Books, New York.

Thuro, Catherine M.

1976 Oil Lamps: The Kerosene Era in North America. Wallace-Homestead Book Co., Iowa.

Tosa, Marco

1987 Classic Dolls. Abbeville Press, New York.

Toulouse, Julian H.

1969 Fruit Jars. Thomas Nelson \& Sons, Camden, New Jersey, and Everybodys Press, Hanover, Pennsylvania.

1971 Bottle Makers and Their Marks. Thomas Nelson, Inc, New York.

U.S. Bureau of the Census

1850a Agricultural Schedule. Grimes County, Texas.

1850b Population Schedule. Grimes County, Texas.

1850c Slave Schedule. Grimes County, Texas.

1853 The Seventh Census. Government Printing Office, Washington, D.C.

1860a Agricultural Schedule. Grimes County, Texas.

1860b Population Schedule. Grimes County, Texas.

1860c Slave Schedule. Grimes County, Texas.

1863 Agriculture in the United States in 1860. Government Printing Office, Washington, D.C.

1870 Population Schedule. Grimes County, Texas.

1880 Population Schedule. Grimes County, Texas.

1900 Population Schedule. Grimes County, Texas.

Vlach, John

1978 The Afro-American Tradition in the Decorative Arts. Cleveland Art Museum, Cleveland.

Wade, Houston (compiler)

1935 Masonic Dictionary: Republic of Texas. Houston Wade, Houston.

Webb, Walter Prescott (editor-in-chief)

1975 The Handbook of Texas. Vols. I and II. The Texas
State Historical Association, Austin.

Wetherbee, Jean

1985 A Second Look at White Ironstone. WallaceHomestead Book Company, Illinois.

Wharton, Clarence R.

1930 Texas Under Many Flags. Vol. V. American Historical Society, Chicago.

White, Henry P., and Burton D. Munhall

1977 Cartridge Headstamp Guide. H. P. White Laboratory, Inc., Bel Air, Maryland.

Wilkie, Laurie A

1996 Glass-Knapping at a Louisiana Plantation: African-American Tools? Historical Archaeology 30(4):37-49.

Williams, Petra

1978 Staffordshire Romantic Transfer Patters. Fountain House East, Jeffersontown, Kentucky.

Williams, Petra, and Marguerite Weber

1986 Staffordshire II Romantic Transfer Patterns. Fountain House East, Jeffersontown, Kentucky.

Wilson, Monica

1971 Religion and the Transformation of Society: A Study in Social Change in Africa. Cambridge University Press, Cambridge.

Wilson, Rex

1981 Bottles on the Western Frontier. University of Arizona Press, Tucson.

Woodhead, Eileen

1991 Trademarks on Base-Metal Tableware. Studies in Archaeology, Architecture, and History. National Historic Sites Parks Service, Environment Canada.

Woodhead, E. I., C. Sullivan, and G. Gusset

1984 Lighting Devices in the National Reference Collection, Parks Canada. Parks Canada, Ottawa.

Young, Amy L.

1996 Archaeological Evidence of African-Style Ritual and Healing Practices in the Upland South. Ms. on file with the author.

Zahan, Dominique

1979 The Religion, Spirituality, and Thought of Traditional Africa (translation of Religion, Spiritualité, et Pensée Africaines). The University of Chicago Press, Chicago.

Zuber, William P.

1903 Letter from William P. Zuber to Thomas P. Buffington, June 26, 1903. William P. Zuber 
Fanthorp Inn State Historical Park

Papers, Center for American History, The

My Eighty Years in Texas. Janis B. Mayfield, University of Texas at Austin. editor, University of Texas Press, Austin. 


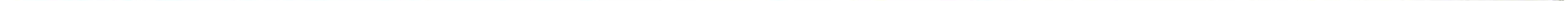

